\title{
8
}
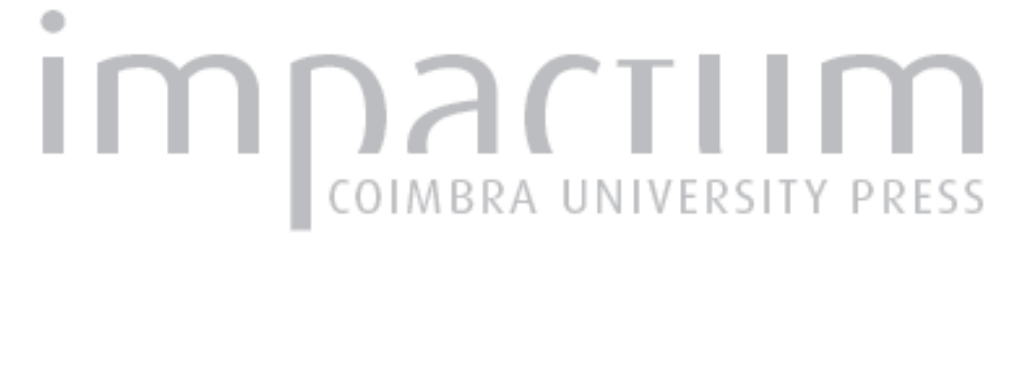

\section{Conflitos políticos no reino de Portugal entre a reconquista e a expansão: estado da questão}

Autor(es): $\quad$ Antunes, José; Oliveira, António Resende de; Monteiro, João Gouveia

Publicado por: Imprensa da Universidade de Coimbra

URL persistente:

URI:http://hdl.handle.net/10316.2/43817

DOI:

DOl:https://doi.org/10.14195/2183-8925_6_2

Accessed : $\quad$ 26-Apr-2023 10:08:23

A navegação consulta e descarregamento dos títulos inseridos nas Bibliotecas Digitais UC Digitalis, UC Pombalina e UC Impactum, pressupõem a aceitação plena e sem reservas dos Termos e Condições de Uso destas Bibliotecas Digitais, disponíveis em https://digitalis.uc.pt/pt-pt/termos.

Conforme exposto nos referidos Termos e Condições de Uso, o descarregamento de títulos de acesso restrito requer uma licença válida de autorização devendo o utilizador aceder ao(s) documento(s) a partir de um endereço de IP da instituição detentora da supramencionada licença.

Ao utilizador é apenas permitido o descarregamento para uso pessoal, pelo que o emprego do(s) título(s) descarregado(s) para outro fim, designadamente comercial, carece de autorização do respetivo autor ou editor da obra.

Na medida em que todas as obras da UC Digitalis se encontram protegidas pelo Código do Direito de Autor e Direitos Conexos e demais legislação aplicável, toda a cópia, parcial ou total, deste documento, nos casos em que é legalmente admitida, deverá conter ou fazer-se acompanhar por este aviso.

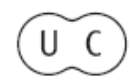




\section{REVISTA DE HISTORIA DAS IDEIAS 6}

\section{. \\ REVOLTAS E REVOLUCOEES}

*

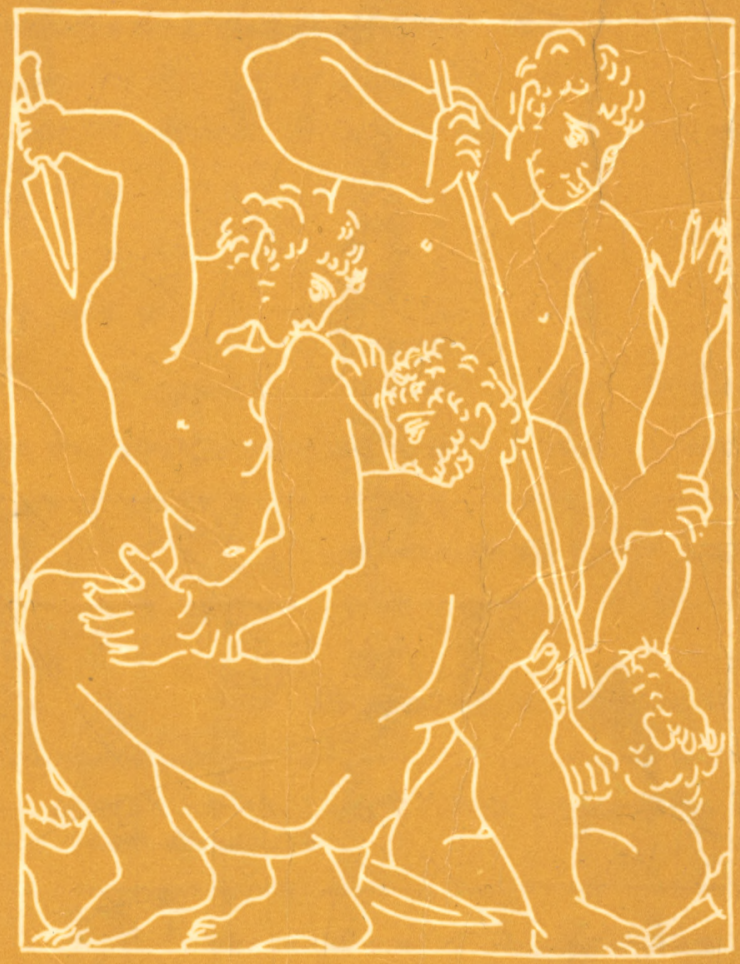

INSTITUTO DE HISTORIA E TEORIA DAS IDEIAS FACULDADE DE LETRAS 
JOSE ANTUNES, ANTÓNIO RESENDE DE OLIVEIRA

e JOÃO GOUVEIA MONTEIRO

\title{
CONFLITOS POLITICOS NO REINO DE PORTUGAL ENTRE A RECONQUISTA E A EXPANSÃO
}

\author{
ESTADO DA QUESTÃO **
}

Numa rápida panorâmica sobre a história de Portugal facilmente constatamos que os períodos politicamente mais conturbados foram aqueles em que a sociedade portuguesa se viu confrontada consigo própria sem a possibilidade de solucionar por completo as várias tensões que a atravessavam num quadro exterior ao território definido no séc. XIII. Este é sem dúvida um dos dados estruturais que nos permite aproximar, do ponto de vista em que nos colocamos, períodos tão diferentes como o Portugal medieval e, por exemplo, o Portugal da primeira metade de oitocentos. Com uma diferença, porém: o ponto de partida é radicalmente diferente em ambos os casos. Com efeito se no período medieval essa possibilidade não pôde ser pensada e concretizada senão a partir do séc. XV, o que terá atenuado os conflitos até então existentes, no séc. XIX é a sua ausência, motivada pela perda do Brasil, que vai criar as condições para um regresso da violência política à história portuguesa.

Reportando-nos apenas ao período medieval, que será objecto do nosso estudo, convém chamarmos desde já a atenção para o alcance e limites do trabalho que nos propusemos realizar. Referiremos de imediato que não estamos perante uma história dos conflitos medievais portugueses. A seriação feita, incidiu apenas sobre aqueles que opuseram o rei aos grandes magnates do reino quer fossem eclesiásticos quer laicos. O ponto de vista adoptado foi, portanto, o da centralização régia e das dificuldades da sua afirmação no contexto

- Faculdade de Letras da Universidade de Coimbra.

** Agradecemos ao Professor Doutor José Mattoso as sugestōes propostas e a atenção que sempre nos dispensou. 
da sociedade medieval. Marginalmente referiram-se ainda alguns conflitos de natureza social, mas apenas quando estes se tornavam necessários para um melhor enquadramento dos primeiros. Finalmente foram propositadamente esquecidos todos os conflitos de carácter senhorial, específicos do período que tratamos, existentes no seio da nobreza e do clero ou opondo ambas estas elites sociais.

Para a definição dos conflitos a incluir no nosso estudo tivemos em conta, prioritariamente, dois elementos fundamentais: o seu carácter violento, com destruições de vária ordem, cercos, combates, assassinatos ou perseguições, e a sua incidência directa, maior ou menor, na organização e estrutura do poder político em Portugal no período considerado. A perspectiva seguida dar-nos-á um conhecimento mais concreto dos principais focos de oposição à afirmação do poder régio e, consequentemente - tomando em atenção as forças sociais em presença, sua implantação regional e as modificações a este nível verificadas no largo período sobre o qual fizemos incidir a nossa atenção -, permitir-nos-á uma primeira aproximação global às confrontações violentas entre o Portugal senhorial e o Portugal monárquico e sua progressão.

A historiografia portuguesa não tem sido muito sensível a esta temática, apesar dos contributos ainda recentes de A. D. de Sousa Costa, Salvador Dias Arnaut e Humberto Baquero Moreno. Os estudos monográficos mais recentes encontram-se dispersos por várias revistas, denotando todavia um crescente interesse pelo tema e abrindo, por vezes, novas perspectivas para a sua compreensão. Pairam no entanto ainda sobre alguns dos conflitos por nós analisados confusões de vária ordem, resultantes por vezes da utilização de obras cuja versão dos acontecimentos foi entretanto ultrapassada em questões mais ou menos pontuais por novos documentos trazidos a público, mas que continuam a servir de base para o estabelecimento dos acontecimentos políticos de um determinado período. Impunha-se portanto fazer um balanço dos conhecimentos adquiridos neste domínio numa síntese global que pudesse servir de ponto de referência e incentivo para trabalhos futuros. Por manifesta falta de tempo e também de espaço, não procuramos, de momento, tirar quaisquer conclusões no capítulo da interpretação dos factos analisados, muito embora não tenhamos prescindido de um enquadramento mínimo dos conflitos incluídos. Procurámos, sempre que nos foi possível, partir da documentação já publicada, tentando precisar a cronologia dos acontecimentos narrados, o que sobrecarregou de certo modo o texto das notas para onde remetemos a elucidação dos pontos mais obscuros com que 
nos fomos confrontando. Não tendo sido concebido como «estado da questão», pelo menos nos moldes em que habitualmente os trabalhos deste tipo são efectuados, este estudo assume-se no entanto como ponto de chegada de todos os contributos dados até ao momento para o conhecimento e compreensão dos conflitos políticos no Portugal medieval, razão pela qual decidimos manter a expressão como subtítulo independentemente dos esclarecimentos pontuais já assina. lados

A cronologia foi estabelecida após uma primeira sondagem conjunta do tema e análise dos dados recolhidos. Para termo a quo foi escolhido o período de 1200-1210 momento em que Sancho I tem os primeiros conflitos violentos, registados na documentação contemporânea, com os bispos portugueses, iniciando um longo contencioso somente atenuado a partir de D. Dinis. A conjuntura política e económica dos inícios do século terá certamente influenciado o deflagrar de tensões que a documentação dos primeiros conflitos refere existirem já nos anos anteriores. Com efeito, as conquistas de Almansor nos inícios da década de noventa do século anterior tinham originado uma paragem na reconquista que se arrastava já sem solução há cerca de duas décadas. A ausência dos proventos económicos da guerra numa sociedade organizada com esse objectivo, e cuja importância foi esclarecida por G. Duby, terá orientado a agressividade militar noutro sentido. As lutas com o reino de Leão, retomadas nesta altura, e o início dos conflitos internos com o clero deverão ser entendidos neste contexto. Acrescente-se a conjuntura económica difícil então vivida, com os maus anos agrícolas da viragem do século, e teremos um quadro ainda mais conducente à procura de novas soluções políticas para a sociedade portuguesa saída da reconquista.

0 termo ad quem encontramo-lo na sujeição da nobreza por D. João II em 1484. Com efeito, a morte dos duques de Bragança e Viseu, concluiu a nosso ver, o longo processo de implantação de um poder político forte e centralizado em Portugal, cujo último obstáculo fora sem dúvida a demonstração de sobranceria e rebeldia de alguns magnates saídos do novo ordenamento da alta nobreza após os conflitos sociais e políticos de finais do séc. XIV.

Uma vez definido o período a analisar, na sua divisão interna procurou-se coadunar o período ao qual cada um de nós se dedica em termos de investigação com os momentos em que, nos conflitos estudados, se verificam pontos de ruptura mais evidentes no que diz respeito à sua progressão, elites ou camadas sociais envolvidas, etc. 
Assim, José Antunes dedicou-se ao período que mediou entre os anos de 1200 e 1280 , momento em que a oposição ao rei proveio em boa parte do clero, mas onde se notam já sinais de uma turbulência nobre que se manifesta de um modo evidente nos acontecimentos de 1245-1248, embora ainda sob a cobertura dada pelo papado a D. Afonso, conde de Bolonha. A partir de 1280 até à década de sessenta do séc. XIV, enquanto a situação da realeza para com o clero começa a ser regularizada através de concordatas, as fracturas verificadas no interior da família régia, criam o clima propício a uma participação mais efectiva da nobreza em apoio do partido que se opõe ao monarca. Esta segunda fase dos conflitos foi analisada por António Resende de Oliveira. Finalmente, João Gouveia Monteiro tratou do período de 1370-1484, onde a continuação dos conflitos entre o rei e a nobreza se complicou, por vezes, com a intrusão de movimentações insurreccionais urbanas, motivadas pela grave conjuntura económica de finais do séc. XIV e primeira metade do séc. XV.

Esclareça-se finalmente que as dificuldades encontradas, na primeira parte do trabalho, para um estabelecimento minimamente preciso da cronologia dos conflitos estudados, obrigaram a um desenvolvimento do texto mais adequado à sua resolução. Tal facto resultou não somente do tipo de fontes que, entre 1200 e 1280 , nos elucidam acerca dos conflitos existentes entre a realeza e o clero, mas também da divergência de opiniões suscitada pelas mesmas nos historiadores que sobre elas se debruçaram. Lembremonos apenas de que estamos no único período, dos três referidos, sistematicamente analisado, do ponto de vista político, pela historiografia portuguesa desde Frei António Brandão. 
1.

O período a que nos vamos reportar (1200-1280) caracteriza-se, de facto, por fortes tensões entre o rei e outras forças da sociedade, nomeadamente o clero e a nobreza.

Começando pelo reinado de D. Sancho I, destacamos, principalmente, as discórdias violentas entre este monarca e os prelados do Porto e de Coimbra.

Para se compreender melhor a evolução dos conflitos entre o bispo do Porto D. Martinho Rodrigues ( ${ }^{1}$ ) e D. Sancho I importa referir, primeiramente, que aquele prelado foi eleito para a Sé Portucalense, provavelmente em $1191\left({ }^{2}\right)$, governando a diocese do Porto durante quarenta e quatro anos, ou seja até 1235 , e que na origem de tais conflitos estão as desavenças entre o cabido e o bispo.

(') D. Martinho Rodrigues era descendente da nobre linhagem de $D$. Gonçalo Mendes da Maia e de D. Urraca Teles e filho de D. Elvira Gonçalves da Palmeira e de Rui Nuno das Estúrias (cf. Portugaliae Monumenta Historica, vol. I, Livros Velhos de Linhagens, ed. crit. por Joseph Piel e José Mattoso, Lisboa, 1980, pp. 125-128).

$\left({ }^{3}\right)$ Dizemos provavelmente porque embora os autores apontem como data da elevação ao episcopado de Martinho Rodrigues o ano de 1191 (cf. obs. cits., na nota 9 deste trabalho), há um diploma régio de Agosto de 1190 (Doação ao mosteiro de Refoios) confirmado do seguinte modo: «Ego donnus Martinus Bracarensium archiepiscopus conf., ego donnus Petrus Tudensium episcopus conf., ego donnus Martinus Portugalensium episcopus conf.». Se este último prelado é Martinho Rodrigues, então teria sido eleito antes ou durante Agosto de 1190 a não ser que se trate de um diploma sem autenticidade. Sobre esta última hipótese João Pedro Ribeiro, Dissertações Chronologicas e Criticas t. III, Lisboa, 1857 , n. ${ }^{\circ} 600$, p. 186, regista o seguinte: Doação no Cartor. do mosteiro de Refoyos de Lima: cópia sem autenticidades. E na nota (b) acrescenta: $\$ \mathrm{~A}$ falta de título = et Algarbii = usado neste período he contra a fé deste documento». Contudo, Rui de Azevedo, Avelino de Jesus da Costa, Marcelino Rodrigues Pereira, Documentos de D. Sancho I, vol. I, Coimbra, 1979, n. ${ }^{\circ} 45$, pp. 70-71 (indicaremos sempre esta obra pela sigla Doc. Sancho I) apresentamo. como autêntico.

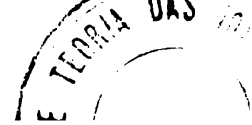


Segundo relata João da Guarda, no Censual do Cabido da Sé do Porto, sucedera na Sé Portucalense, ao bispo D. Fernando Martins, morto em 8 de Novembro de 1185, Martinho Pires. Este prelado viveu quase cinco anos naquela cadeira pontifical e depois fora eleito arcebispo de Braga, tendo-lhe então sucedido na Igreja do Porto, "Martinho Rodrigues, Tesoureiro da mesma Igreja, o qual, depois de ser bispo, de nenhum modo queria repartir com os cónegos as rendas do bispado" $\left({ }^{3}\right)$.

De facto, Martinho Pires, ainda como bispo do Porto, tinha procedido a uma reforma do cabido. Antes, todos os cónegos eram observantes da regra de Santo Agostinho: «dormiam numa casa, comiam noutra e viviam em clausura". 0 bispo, além de outras disposições, dividiu as rendas do bispado em três partes, ficando duas para o prelado e uma para o cabido, passando os cónegos a ter rendas separadas e a viver livre e independentemente. Mas logo que Martinho Rodrigues foi elevado à Sé Episcopal do Porto, por eleição dos colegas, procurou sujeitar novamente o cabido à anterior vida regular e comum, querendo só dar-lhe provimento ao seu sustento c vestuário. Os cónegos reagiram e apelaram para o Metropolita de Braga que interveio e conseguiu harmonizar as duas partes em litígio, fazendo voltar tudo à reforma que ele fizera, apenas com algumas modificações. E assim ficou sanada a contenda: "et fuit sedata contentio" $\left({ }^{4}\right)$.

Ora esta primeira divisão, como o Censual refere «foi feita no tempo de D. Sancho, em 1195, por Martinho, bispo do Porto, com a intervenção de D. Martinho, Arcebispo de Braga, para que o não inquietassem mais durante a sua vida" $\left({ }^{5}\right)$.

Contudo, não tardou que este acordo se rompesse e surgisse um segundo conflito, acusando os cónegos D. Martinho Rodrigues de ter falseado a composição. Interveio novamente o arcebispo de Braga, D. Martinho Pires e firmou.se um novo acordo pelo qual ficou regulado não só a forma da administração das rendas do cabido e da cobrança de alguns impostos, a nomeação e substituição de um prebendário ou prepósito para o governo da terça parte dos rendimentos dos

(') Censual do Cabido da Sé do Porto. Códice membranácio existente na Biblioteca do Porto, Porto, 1924, pp. 493-494. O mesmo texto é transcrito e comentado por D. Rodrigo da Cunha, Catálogo dos Bispos do Porto, Porto, MUCCXLII, II Parte, c. VII, pp. 32-34; cf. Monarquia Lusitana, Parte IV, Imprensa Nacional Casa da Moeda, Lisboa, 1974, Livro XII, cap. IX, p. 16.

(4) Censual do Cabido da Sé do Porto, p. 494.

(5) Ibidem, p. 497. 
cónegos, o pagamento ao cabido de uma indemnização de nove bizâncios, mas também a questão da apelação, caso os cónegos ou o prepósito ou prebendário se sentissem lesados e não obtivessem do seu prelado a devida reparação. Então, deviam recorrer primeiramente ao Metropolita de Braga e se, porventura, não resultasse, poderiam recorrer ao rei, mas deveriam munir-se, previamente, de cartas do Arcebispo para D. Sancho com a informação de toda a verdade "para não levantarem, sem razão, o ânimo daquele monarca contra» Martinho Rodrigues $\left({ }^{\circ}\right)$.

Este acordo firmou-se na presença de D. Martinho Pires e de diversos cónegos da Sé do Porto, Braga, Coimbra e Lisboa, aos 8 de Outubro de $1200\left(^{7}\right)$.

Contrariamente a Alexandre Herculano $\left({ }^{8}\right)$ e a José A. Ferreira, Fortunato de Almeida e Ångelo Ribeiro ( $\left.{ }^{9}\right)$, que interpretam as palavras "para não levantarem sem razão, o ânimo daquele monarca contra ele» como sinal de que antes de 1200 já provavelmente $D$. Sancho interviera na discórdia particular do bispo e do cabido e que esta se prolongou depois de 1200, Luís Gonzaga de Azevedo julga que dadas as excelentes relações entre D. Sancho I e o prelado, não significam "que tivesse havido antes de 1208 qualquer desgosto sério entre os dois" $\left({ }^{10}\right)$. E Miguel de Oliveira, partilhando da mesma opinião defende igualmente que não deve inferir-se do referido texto qualquer intervenção de D. Sancho a favor do cabido, mas apenas que tais questões não saíssem do foro eclesiástico e que não oferecessem pretexto para o rei se desgostar com o prelado ( $\left.{ }^{11}\right)$.

Mas devem ter surgido dificuldades entre o cabido e o seu bispo nos sete anos que se seguiram a este acordo para Martinho Rodrigues pedir ao papa Inocêncio III em 1207 a confirmação da concórdia de 1200 , o que obtém em 30 de

t. V, p. 96 .

( $\left.{ }^{\circ}\right)$ Ibidem, p. 500. Ver também João Pedro Ribeiro, ob. cit.,

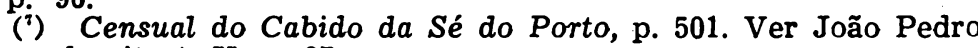
Ribeiro, ob. cit., t. V, p. 97.

(') Alexandre Herculano, História de Portugal, t. II, 1. III, Livraria Bertrand, 1980 , p. $13 \%$; e ainda nota VII do fim do volume, pp. 584-585.

( $\left.{ }^{\circ}\right)$ José Augusto Ferreira, Memorias Archeologico-Historicas da cidade do Porto, t. I, Braga, 1923, p. 192. Fortunato de Almeida, História da Igreja em Portugal, dir. Damião Peres, vol. I, Barcelos, 1967 , p. 169. Ângelo Ribeiro, «O rei e os prelados», in História de Portugal, dir. Damião Peres, vol. I, Barcelos, MCMXXIX, p. 158.

${ }^{\left({ }^{10}\right)}$ Luís Gonzaga de Azevedo, História de Portugal, vol. V, Lisboa, 1942, pp. 38-39.

(1) Miguel de Oliveira, «O senhorio da cidade do Porto», Lusitania Sacra, Lisboa, 1959, t. IV, p. 44. 
Julho do mesmo ano. Aliás, o documento papal da confirmação, transcrito no Censual ( ${ }^{12}$ ) explicita que os cónegos a transgrediam ou se recusavam a observar, o que levou certamente aquele prelado a recorrer ao papa Inocêncio III, tendo este pontífice obrigado a cumprir o acordo sob pena de incorrerem em censura eclesiástica, encarregando da execução de tal confirmação o cantor e Mestre Escola de Coimbra e João Pais, cónego da Sé de Braga $\left({ }^{13}\right)$.

Segundo Luís G. de Azevedo o motivo do primeiro conflito entre o rei e Martinho Rodrigues está no facto de os cónegos recorrerem a D. Sancho quando se sentiram suplantados pela referida confirmação do papa à concordata de 1200 e consequentemente o seu descontentamento com a execução da mesma. Então, D. Sancho, predisposto como estava, para se intrometer em questões eclesiásticas, não se fez rogado. $\mathrm{E}$ data tais questões de $1208{ }^{\left({ }^{14}\right)}$. Miguel de Oliveira é, sensivelmente, da mesma opinião $\left({ }^{15}\right)$. Alexandre Herculano e José A. Ferreira defendem que foi, de facto, antes de 1208 que as discórdias de D. Sancho I e do bispo chegaram ao auge em que no-las descrevem duas bulas de Inocêncio III, expedidas em Maio de $1210\left({ }^{10}\right)$.

Contudo, num ponto se encontram todos os autores de acordo: que as referidas discórdias entre o rei, que tomou o partido do cabido, e o bispo tiveram lugar antes do casamento do Infante D. Afonso com D. Urraca, celebrado em fins de 1208 ou princípios de $1209{ }^{(17)}$. E aliás o que parece concluir-se das introduções não só da bula Graves oppressiones dirigida a D. Martinho e a mestre Florêncio, respectivamente bispo e arcediago de Zamora e ao abade Elberto de Moreruela, como da bula Justis petentium enviada ao próprio bispo do Porto, ambas datadas de 13 de Maio de $1210\left({ }^{18}\right)$.

() Esta composição tem o seguinte título: «Mandat dominus papa quod compositio supra scripta observetur inter episcopum et capitulum, (Censual do Cabido da Sé do Porto, cit., p. 501).

(20) Ibidem, p. 501.

("i) Luís G. de Azevedo, ob. cit., p. 38.

('s) Miguel de Oliveira, art. cit., p. 46.

(10) Alexandre Herculano, ob. cit., t. II, 1. III, p. 137 e nota VII do fim do volume, pp. 584-585; cf. também as notas críticas 1) e 2) de José Mattoso a esta nota VII, in Alexandre Herculano, ob. cit., t. II, p. 650; vide José A. Ferreira, ob. cit., p. 193.

(') Relativamente à data da celebração do casamento de $D$. Afonso com D. Urraca ver a nota seguinte $39 \mathrm{em}$ que se procura, depois de apresentar os factos, fornecer alguns elementos para melhor situar os conflitos.

$\left({ }^{18}\right)$ As principais fontes sobre os conflitos entre o bispo do Porto e D. Sancho I são as três bulas Justis petentium, Grave gerimus et indignum e Graves oppressiones, todas datadas de 13 de Maio de 
Segundo estas bulas os conflitos surgidos entre o rei e Martinho Rodrigues, antes do referido casamento, têm como motivo D. Sancho haver-se intrometido, a pedido do cabido, nas questões entre o bispo e os cónegos ${ }^{19}$ ).

Assim, pela bula Graves oppressiones, o papa manda aos delegados apostólicos que obriguem o rei de Portugal a restituir tudo o que tinha arrebatado ao bispo do Porto. Este documento pontifício parece ter como finalidade essencial abordar os acontecimentos e as violências depois do casamento de D. Afonso com D. Urraca. Contudo, logo na introdução, constituída pelo primeiro parágrafo, refere-se, explicitamente, não só a graves opressões e enormes injúrias que o rei exer-

1210, quando já Martinho Rodrigues se encontrava em Roma, podendo relatar de viva voz os acontecimentos. natural, portanto, que os conflitos descritos nas bulas toquem o exagero e levantem legítimas dúvidas sobre a existência de um certo arranjo na sua elaboração a fim de se tornarem mais eficazes nos seus efeitos. A mesma data, a descrição de factos muito anteriores à fuga do bispo para Roma, o facto da bula Justis petentium ser dirigida ao próprio bispo do Porto com a inserção de uma antiga e primeira composição entre o mesmo e o monarca (e que provavelmente lhe foi entregue em Roma) e os factos posteriores, parecem confirmar esta suspeita. Note-se que se desconhecem os argumentos do rei a refutar todas as acusações da bula. Sabe-se apenas pela bula $S i$ te diligenter attenderes, de 23 de Fevereiro de 1211, enviada por ocasião do conflito entre D. Sancho I e o bispo de Coimbra D. Pedro Soares, que o monarca se queixou de que o papa prestava ouvidos a quem dizia mal do rei, parecendo-nos pressentir, no mesmo documento, uma certa compreensão por parte do papa para com D. Sancho I, depois deste apresentar as suas razões embora o admoeste com uma certa dureza. Obviamente se desconhece se D. Sancho se serviu para defender a sua causa em Roma, como o fez o seu sucessor D. Afonso II, de procuradores idóneos. Esta presumível lacuna do rei leva-nos até a acreditar num certo exagero das referidas bulas, pois aquando do conflito entre D. Afonso II e as irmãs, o papa, depois de ouvir os procuradores do rei, retrocedeu algumas vezes na sua intransigência e acabou até por dar o seu aval às pretensões fundamentais de D. Afonso II, como adiante referiremos. (Para os textos das três bulas citadas servimo-nos principalmente da obra de Demetrio Mansilla, La Documentacion Pontificia Hasta Inocencio III, (965-1216), Roma, 1955, n. ${ }^{\circ} 435,436$ e 437, pp. 463-468; ref. em Augustus Pothast, Regesta pontificum romanorum, vol. I, Berolini, MDCCCLXXIII, n. ${ }^{\circ} 4001$ e 4002, p. 345; Estas bulas encontram-se publicadas, em parte, por Joaquim dos Santos Abranches, Fontes do Direito Ecclesiastico Portuguez, I, Summa do Bullario Portuguez, Coimbra, 1895, n. 1803, 1804 e 1805, pp. 273-275 (daqui em diante designaremos esta obra apenas por Summa do Bullario Portuguez) e também pelo Visconde de Santarém, Quadro Elementar das Relaçöes Diplomaticas de Portugal, Lisboa, 1864, pp. 36-39. Para a bula $S i$ te diligenter attenderes vide nota seguinte n. ${ }^{\circ} 40$.

$\left.{ }^{10}\right) \mathrm{Cf}$. Grave gerimus et indignum, in Demetrio Mansilla, ob. cit., n. ${ }^{\circ} 435$, p. 463 ; vide também Justis petentium, in Demetrio Mansilla, ob. cit., n. ${ }^{\circ} 437$, pp. 467-468. 
cera sobre o prelado, antes do casamento e que segundo a mesma bula seria até impossível enumerá-las, mas principalmente a uma composição que também anteriormente tinha sido celebrada entre ambos, por intermédio dos delegados pontifícios, e que o próprio rei tinha assinado pelo seu punho e prometido fielmente observar, mas cujo articulado agora desrespeitava, renovando contra o referido prelado calúnias ainda mais graves e infligindo-lhe angústias ainda mais terríveis $\left({ }^{20}\right)$.

A composição a que se refere, vem transcrita na bula Justis petentium de 13 de Maio de 1210 e que Inocêncio III confirma. Dela se conclui que Martinho Rodrigues, desrespeitado na sua autoridade lançou o interdito na cidade. Então os oficiais do rei praticaram tais violências contra ele e contra os seus parentes, que teve de fugir, tendo sido despojado dos seus bens, alfaias e cavalgaduras. Com ele sofreram roubos e outras violências seus parentes, como, por exemplo, o seu irmão Pedro Rodrigues que foi preso pelo rei ou pelos seus oficiais. Martinho Rodrigues recorreu ao papa informando-o da situação em que se encontrava. O papa deu então plenos poderes ao bispo de Zamora, ao deão da mesma Sé e ao mestre escola de Leão para terminarem a contenda sem apelação e obrigarem $D$. San`ho a dar a devida reparação. 0 rei submeteu-se às condições impostas pelos delegados apostólicos aprovando e prometendo observar as determinações da referida composição, da qual destacamos as seguintes: receber antes de tudo o bispo e os seus; restituir-lhe o bispado na sua devida integridade e o seu património; não se intrometer nas causas dos religiosos e clérigos do bispado; não fazer justiça pelas suas próprias mãos sobre os súbditos do bispo; nas causas contra o bispo e os seus que a justiça fosse feita pelo Arcebispo ou apenas pelo Sumo Pontífice; não proteger os adversários do prelado; entregar-lhe as cavalgaduras, alfaias e outros bens; pôr em liberdade o cavaleiro Pedro Rodrigues; restituir dentro de dois meses depois do regresso do bispo à cidade e do levantamento do interdito os bens desaparecidos; não apelarem ambos a curto prazo; abster-se o rei de se intrometer nos assuntos da fábrica da Igreja $\left({ }^{21}\right)$.

Ficaram, assim, restabelecidas, as relações entre o rei e o bispo ${ }^{22}$ ).

\footnotetext{
$\left({ }^{20}\right)$ Graves oppressiones, ob. cit., p. 464.

(21) Cf. Justis petentium, ob. cit., pp. 467-468.

$\left.{ }_{(22}\right)$ Embora os primeiros conflitos entre o rei e o bispo tenham tido lugar antes do casamento de $D$. Afonso com D. Urraca, desconhece-se a data exacta ou o espaço de tempo em que se verificaram,
} 
Contudo, passado algum tempo, levantou-se um novo conflito não menos violento que o anterior, dando crédito aos documentos pontifícios. Os motivos e as violências encontram-se especificados nas bulas Graves oppressiones e Grave gerimus et indignum, também de 13 de Maio de $1210\left({ }^{23}\right)$. E possível que tenham existido outros motivos, porém, a bula Graves oppressiones apenas refere que D. Sancho se indignou contra Martinho Rodrigues por este se recusar não só a assistir ao casamento do príncipe D. Afonso com a sua prima a infanta D. Urraca, filha de Afonso VIII de Castela, com o fundamento de que eram parentes $\left({ }^{24}\right)$, mas também por se ter negado a receber festivamente com uma procissão, os noivos, quando passaram pela cidade do Porto $\left({ }^{25}\right)$.

Renovaram-se, então, as antigas discórdias. A maior parte do cabido seguiu a facção de $\mathrm{D}$. Sancho. $\mathrm{O}$ deão e alguns outros o partido do bispo. Os burgueses do Porto, descontentes com Martinho Rodrigues porque recusavam ser seus súbditos e vassalos, apesar da concessão feita por D. Teresa ao bispo D. Hugo e seus sucessores, lançaram se na contenda, alegando a carta de foral, mas do lado do monarca, talvez na esperança de merecerem a libertação do governo e do poder eclesiástico a que o bispo os sujeitara. Seguiram-se então as maiores violências. Segundo a mesma bula D. Sancho mandou destruir as casas dos cónegos partidários do bispo, tomou-lhes as prebendas e cavalgaduras, arrombou-lhes as portas

assim como da composição inserida na bula Justis petentium. Terá sido entre Junho de 1206 a Julho de 1207, espaço em que são tornados públicos cinco diplomas régios, um dos quais («Carta de Couto ao mosteiro de Santa Maria de Miranda", em 20 de Junho de 1207) é confirmado por quatro prelados, com a excepção de Martinho Rodrigues? O certo é que em Julho de 1207 o prelado pede ao papa a confirmação da composição de 1200 e depois daquela data Martinho Rodrigues confirma todos os documentos até Janeiro de 1208 (Cfr. Doc. Sancho I, n. 165 a 168 , pp. 253-257; n..$^{\circ} 238$, pp. 349-351; n. ${ }^{\circ} 169$, pp. 258-259; n. ${ }^{\circ} 237$, p. 349). Caso tais desavenças não tenham tido lugar naquele período, também não é incompatível que tenham acontecido em qualquer espaço de tempo entre Janeiro e Dezembro de 1208, em que foram publicados oito diplomas régios, três dos quais estão confirmados por D. Martinho Rodrigues, um em Janeiro, outro em Agosto e um terceiro em Setembro. (Vide Doc. Sancho I, n. ${ }^{*} 173-178$, pp. 264-270; 239, pp. 351-352; 179, pp. 271-272).

$\left({ }^{33}\right)$ Cf. Demetrio Mansilla, ob. cit., pp. 463-466.

(24) O Infante D. Afonso era primo em 3.0 grau de D. Afonso VIII, rei de Castela.

$\left.{ }^{25}\right)$ São significativas as seguintes expressões da bula: «....indignatus siquidem ei, pro eo quod illicitis nati sui nuptiis interesse ac eidem transeunti per civitatem processionem facere denegavit» (Graves oppressiones, in Demetrio Mansilla, ob. cit., n. 436, p. 464). 
das igrejas, introduziu lá os excomungados, mandou dar sepultura eclesiástica aos interditos que morreram. $\mathbf{O}$ próprio bispo, o deão e outros que tinham tomado o seu partido foram presos e cercados no paço episcopal durante cinco meses, por meio do porteiro do rei e pelos burgueses da cidade do Porto de tal modo que nem sequer lhes davam licença de sair, nem facultavam a entrada a um confessor que administrasse os sacramentos ao prelado durante uma doença que entretanto lhe sobreveio. Então, Martinho Rodrigues, sentindo-se desacreditado e vendo que os cónegos e raçoeiros da Sé celebravam solenemente os ofícios divinos, desprezando o interdito e a apelação ao papa $\left({ }^{28}\right)$, viurse coagido a declarar aos oficiais régios que se entregavam à vontade do monarca. Porém, e ainda segundo o mesmo documento, ao ver-se finalmente livre da prisão e intuindo que o rei o queria constranger a aceitar uma composição desvantajosa e a renunciar à apelação ao papa, fugiu durante a noite e com muita dificuldade saiu do reino, para Roma, a fim de recorrer a Inocêncio III onde chegou em extrema miséria e desprovido de roupas $\left.{ }^{27}\right)$. Entretanto, o referido porteiro do rei, invadindo os bens do bispado, que aplicava em seu proveito e no do rei, prendeu o homem a quem porventura o prelado dera o encargo de administrar os seus bens e de lhe mandar com que pudesse viver fora do reino $\left({ }^{28}\right)$.

Perante tal situação Inocêncio III ordenou aos delegados pontifícios que obrigassem o monarca a restituir os bens de que se tinha apoderado e a dar satisfação das injúrias ao bispo e deão da Sé do Porto e a todos os companheiros ofendidos e a fazer observar eficazmente e com prudência a composição feita em tempos, dando-lhe, assim, um certo prazo,

(*) Angelo Ribeiro é da opinião que D. Sancho precedera o bispo no apelo para a Sé de Roma solicitando ao papa uma medida de ordem geral com a qual pretendia precaver-se contra as possíveis imposiçōes de interdito por parte de qualquer prelado descontente. De facto, pela bula Ut ex speciali devotione de 4 de Setembro de 1209 , Inocêncio III concede ao rei que nenhum delegado subdelegado, ou conservador da Santa Sé possa fulminar contra o soberano ou contra o reino a pena de excomunhão, sem especial mandato de Roma, em que venha transcrita de verbo ad verbum esta mesma bula. Mas oito meses depois, isto é, em 13 de Maio de 1210 pelas bulas Graves oppressiones e Justis petentium o papa dava satisfação às queixas de Martinho Rodrigues (cf. bula Ut ex speciali devotione, in Summa do Bullario Portuguez, n..$^{\circ} 1802$, p. 273; Quadro Elementar, p. 35; Vide Angelo Ribeiro, «O rei $e$ os prelados», in História de Portugal, dir. de Damião Peres, vol. II, Barcelos, MCMXXIX, p. 159.

(") Graves oppressiones, in Demetrio Mansilla, ob. cit., p. 464.

(*) Ibidem, p. 465. 
de tal modo que se o rei não quisesse cumprir o que o papa determinava dentro do tempo estabelecido, deveriam proibir-lhe a entrada na Igreja, privá-lo da recepção dos sacramentos e da participação nos ofícios divinos os quais deveriam cessar imediatamente nos lugares onde o rei chegasse. E se mesmo assim a dureza do rei não abrandasse, deviam comunicá-lo por escrito ao papa, pois se os males se agravassem, então deveria aplicar-se para a sua cura um remédio muito mais eficaz $\left({ }^{29}\right)$.

Quanto ao porteiro, e a dois dos seus servos e aos burgueses, as ordens de Inocêncio III eram muito mais severas, visto ter-se provado que tinham sido os autores da prisão do bispo, do deão e dos seus companheiros e ainda porque o porteiro prendera com uma cadeia de ferro um subdiácono do próprio prelado $\left({ }^{30}\right)$. Por isso mandava que fossem, por toda a diocese, solenemente declarados excomungados vitandos até que dessem total satisfação aos que sofreram tão grandes injúrias e fossem a Roma munidos com cartas dos delegados pontifícios para serem absolvidos ( ${ }^{31}$ ).

E de facto, concluído o processo, os mesmos delegados apostólicos, proferiram a sentença em 12 de Novembro de 1211 na qual vêm nominalmente citados vinte cidadãos portucalenses que incorreram nas penas canónicas. Entre todos foram declarados infames e excomungados os doze seguintes: João Alvo e seu irmão Mendo Guilherme; Vicente Mendes, genro de João Alvo; Afonso Gordom das Eiras; Tirou Martins Pires e Vicente, genros de Pedro Feio (Petri Fedi), Pedro Soares, filho de Soeiro Moniz; João Vai-Vai; Fernando Monis; Gonçalo Godinho; Pedro Mouro e Pirro das Eiras. E incursos também em excomunhão os oito restantes: Pedro Feio (Petrum Fedum) ( $\left.{ }^{32}\right)$, Paio Martins, Mendo Bicas, Soeiro Gui-

(*) Ibidem, p. 465.

(\$) Ibidem, p. 465 .

("1) Ibidem, p. 465.

('s) A interpretação de Alexandre Herculano, ob. cit., t. II, p. 144, sobre Pedro Feudo-Tirou, carece de fundamento, porque não houve nenhum alcunhado de Feudo-Tirou. Na lista dos burgueses excomungados que se encontra na sentença dos delegados pontifícios, de 12 de Novembro de 1211 , vêm citados Pedro Feio (Petrum Fedum) e Tirou Martins Pires, genro de Pedro Feio. Deste modo Pedro Feio e Tirou são personagens totalmente distintos (cf. Corpus Codicum Latinorum Portugalensium, II, Porto, 1891 e ss., p. 49, onde vêm publicados os nomes dos burgueses portuenses excomungados; $c$. também sobre esta mesma questão Miguel de Oliveira, $O \mathrm{O}$ senhorio da cidade do Porto», Lusitania Sacra, t. IV, Lisboa, 1959, pp. 47-48, em que refuta totalmente a interpretação de $\mathrm{A}$. Herculano; também José Mattoso, na ob. cit., de Alexandre Herculano, t. II, l. III, nota crítica 
lherme, João Ferreiro do Monte, João Surdo, Reinaldo Agulheiro e Miguel Meigenga $\left({ }^{83}\right)$.

Entretanto, D. Sancho, sentindo-se bastante enfermo $\left({ }^{34}\right)$, decidiu proceder às suas últimas disposições, fazendo o seu testamento em Outubro de 1210. Nele contemplava, com grande generosidade, o clero, pedindo, além disso, ao papa, que o confirmasse, legando-lhe a larga soma de cem marcos de ouro $\left({ }^{35}\right)$.

Por sua vez, Martinho Rodrigues, devia ter regressado

75 , p. 184, recusa a mesma interpretação; Narciso de Azevedo, na sua obra Hearo Feudo-Tirou - Historia e lenda dum portuense do século XIII, Porto, MCMXXXV, pp. 119-132, ironiza e critica Alexandre Herculano provando que a bula Graves oppressiones nomeia três e não dois vizinhos do burgo, a saber: «....nec non J. Album, P. Feudum. Tirou. \& omnes alios....» e que Feudum está manifestamente em vez de Foedum. Além disso prova que era inadmissível que $o$ povo portuense, no começo do século XIII, empregasse o vocábulo feudo, baseando-se, inclusivamente, na própria autoridade de Alexandre Herculano. Termina a sua argumentação com parte da transcrição da sentença da excomunhão onde, como é óbvio, se destaca Tirou como um personagem totalmente diferente, provando, assim, a impossibilidade de os burgueses do Porto terem inventado semelhante alcunha.

${ }^{\left({ }^{3}\right)}$ Corpus Codicum, pp. 48-49. O documento vem datado sob a era Millia. CC.XL.IX, ou seja 1211 na era cristã. Cf. também bula Graves oppressiones, in Demetrio Mansilla, ob. cit., p. 465 onde o papa apenas refere, como se disse, os nomes de J. Album, P. Feudum e Tirou.

${ }^{(34)}$ «....dum ipsum affligens egritudine corporali, eundem ad sanandas egritudines spirituales induxit.... Unde licet infirmus corpore, animo tamen sanus» (bula Is, qui tangit montes, in Demetrio Mansilla ob. cit., n. ${ }^{\circ} 454$, p. 482); ref. em Augustus Pothast, ob. cit., n. ${ }^{\circ} 255_{1}$ p. 367 e em Summa do Bullario Portuguez, ob. cit., n. ${ }^{\circ} 1814$, pp. 280 -281; vide também Luís Gonzaga de Azevedo, ob. cit., pp. 45-46.

$\left.{ }^{35}\right)$ Enquanto a bula Is, qui tangit montes parece querer insinuar que $D$. Sancho se encontrava perfeitamente senhor das suas faculdades, empregando a expressão textual e técnica animo tamen sanus (cfr. nota 34), o seu sucessor D. Afonso II vai mais tarde contestar esta afirmação, defendendo, por ocasião do litígio com as suas irmãs, que seu pai compos non fuerat mentis suae (cf. bula Dilectı filii fratres, transcrita por A. Domingues Sousa Costa, in Mestre Silvestre e Mestre Vicente, juristas da contenda entre D. Afonso II e suas irmãs, Braga, 1963, pp. 26-27; cf. Monarquia Lusitana, Parte IV, l. XII, cap. XXXIIII, pp. 60-61).

O testamento datado de Outubro de 1210, vem transcrito in Doc. Sancho I, n..$^{\circ} 194$, pp. 297-301; cf. Monarquia Lusitana, Parte IV, cap. XXXV, pp. 61-64 e Escritura III, pp. 260-261. Sobre o aproveitamento de um exemplar com data errada cf. José Mattoso, in Alexandre Herculano, ob. cit., t. II, l. III, nota 76. p. 184; aliás L. Gonzaga de Azevedo, ob. cit., p. 46 data o testamento de Setembro de 1209 e na p. 53 de Outubro de 1209; Fortunato de Almeida, História da Igreja em Portugal, vol. I, Barcelos, 1976, p. 171, embora não refira o mês, data-o também de 1209 . 
de Roma com as bulas de Inocêncio III a que os delegados apostólicos procuravam dar cumprimento. Porém, D. Sancho I, adiantando-se à intervenção dos delegados pontifícios, talvez por influência do Arcebispo de Braga, do abade de Alcobaça, do prior de Santa Cruz e de D. Pedro Soares, bispo de Coimbra, publicou um diploma régio dirigido aos bispos e abades e, em geral a todo o clero, em que lhe dava satisfação às suas reivindicações, prometendo respeitar-lhe as imunidades, regulando a isenção do serviço militar, o imposto da colheita, o recebimento durante as caçadas régias, etc. $\left({ }^{36}\right)$.

Assim, quando nos finais de 1210, Martinho Rodrigues lhe escreveu uma carta pedindo reparação e segurança para poder entrar no reino e na sua diocese, respondeu-lhe que já tinha encarregado o prior de mosteiro de Nandim com oficiais públicos escolhidos, para lhe preparar não só a entrada na cidade e diocese, mas também para lhe restituir todos os seus bens e rendas de que fora esbulhado $\left({ }^{37}\right)$. E relatando- lhe tudo o que já tinha feito ao clero em ordem a repôr todas as coisas no seu devido lugar, terminava resordando-lhe passados favores que lhe fizera, podendo, portanto, regressar confiadamente para governar a sua diocese e estar em qualquer parte do reino que mais lhe agradasse $\left({ }^{38}\right)$.

Em 12 de Dezembro de 1210 já Martinho Rodrigues confirma, em Santarém, o diploma régio da «Doação a Fernando Nunes», juntamente com os outros prelados e o próprio rei $\left.{ }^{39}\right)$.

${ }^{\left({ }^{36}\right)}$ Cf. Doc. Sancho I, n. ${ }^{\circ} 206$, p. 313; L. Gonzaga de Azevedo,
ob. cit., pp. $45-46$.
${ }_{\left({ }^{37}\right)}$ Cf. Doc. Sancho I, n. ${ }^{\circ} 206$, pp. 313-314. Segundo José A. Ferreira, o mosteiro de Nandim possuia o couto de Palmeira, nas terras em que eram senhores os membros da família do bispo D. Martinho Rodrigues (cf. José A. Ferreira, ob. cit., p. 199, nota 1.

$\left.{ }^{38}\right)$ Doc. Sancho $I$, n. ${ }^{\circ} 206$, p. 314.

${ }^{(3)}$ Cf. Doc. Sancho I, n. ${ }^{\circ} 198$, pp. 304-305. O espaço de tempo durante o qual parece ter sido mais violento o conflito entre D. Sancho I e o bispo do Porto, abrangendo primeiramente um certo contencioso e depois a perseguição e a prisão durante cinco meses, com a fuga para Roma, deve situar-se entre Setembro de 1208 e 13 de Maio de 1210, dando crédito aos motivos dos conflitos mencionados na bula, isto é, a recusa do prelado na participação do casamento de Afonso com D. Urraca e o não recebimento dos noivos na cidade do Porto. Ora a celebração do casamento deve ter-se verificado em fins de 1208 ou princípios de 1209, porque os últimos documentos em que o príncipe $D$. Afonso figura antes de se mencionar a sua esposa D. Urraca, datam de Agosto ou de Setembro de 1208 e os primeiros diplomas em que se menciona $D$. Urraca como confirmante situam-se a partir de 25 de Fevereiro de 1209 , o que significa, portanto, que a celebração do casamento deve ter ocorrido entre Agosto ou Setembro de 1208 e 25 de Fevereiro de 1209. (Cf. Doc. Sancho I, n. ${ }^{\circ} 176-180$, pp. 268- 
Também entre o bispo de Coimbra, D. Pedro Soares e D. Sancho I, surgiram graves dissensões. E a conclusão a que se chega através das bulas pontifícias Vehementer nos zelus, Licet venerabilis e Si te diligenter attenderes, todas datadas de 23 de Fevereiro de 1211, dirigidas as duas primeiras ao arcebispo de Compostela e a última ao próprio D. Sancho I $\left({ }^{40}\right)$.

Como as bulas são posteriores às desavenças entre o bispo de Coimbra e D. Sancho, de tal modo que quando foram expedidas de Roma, já há muito que em Portugal estavam

-273; n. ${ }^{\circ} 239$, pp. 351-352. Dizemos Agosto ou Setembro porque a «Doação a Martinho Fernandes» ocorrida em Setembro de 1208, em que aparece como confirmante $\mathrm{D}$. Afonso, é de data duvidosa. Cf. também João Pedro Ribeiro, ob. cit., t. III, n. ${ }^{\circ} 701$, p. 210). Sendo assim, é possível, quer antes quer depois do casamento, que as relações apenas se tenham tornado tensas e se tenha mantido um certo contencioso, pois Martinho Rodrigues continua desde Setembro de 1208 até Maio de 1209 a confirmar regularmente os diplomas régios em conjunto com o rei, os príncipes e os outros prelados. Basta recordar que dos oito diplomas, cinco são confirmados por ele, e destes são confirmados quatro em conjunto com D. Urraca (Doc. Sancho I, n. ${ }^{\circ}$ 239, pp. 351-352; n. ${ }^{\circ}$ 180-185, pp. 272-282; João Pedro Ribeiro, ob. cit., t. III, n. ${ }^{\circ} 701$, p. 210; n. ${ }^{\circ}$ 702, pp. 210-211, n. ${ }^{\circ} 722$, pp. 216-217). De Maio de 1209 a 1 de Janeiro de 1210 , num espaço de sete meses, foram tornados públicos dois diplomas régios que não são confirmados nem pelos prelados nem por D. Urraca (Doc. Sancho I, n..$^{\circ} 186$, pp. 283-286; n.o 187, pp. 286-287). O último documento que o prelado do Porto confirmou antes da sua fuga para Roma e depois destes sete meses, foi precisamente em 1 de Janeiro de 1210 (Doc. Sancho I, n. ${ }^{\circ}$ 188, pp. 288-289), seguindo-se um período de doze meses em que nunca mais é mencionado como confirmante, voltando a aparecer como tal apenas em 12 de Dezembro de 1210 , depois de ter regressado de Roma (Doc. Sancho I, n..$^{\circ} 198$, pp. 304-305; João Pedro Ribeiro, ob. cit., t. III, n. ${ }^{\circ} 707$, p. 212). Portanto, é entre 1 de Janeiro de 1210 e a data das bulas pontifícias de 13 de Maio de 1210 (que referem as violências contra o prelado), que provavelmente se devem situar não só a prisão e a destruição dos bens do prelado, dos seus parentes e dos cónegos seus partidários, mas principalmente a sua fuga para Roma. Embora também não repugne que entre Maio de 1209 e 1 de Janeiro de 1210 (no referido espaço de sete meses), se tenha dado porventura um conjunto de violências e a própria prisão do bispo e depois tenha feito perceber ao rei que estava disposto a ceder (compulsus est nuntiis regis dicere, quod se illius exponeret voluntati), podendo dar-se o caso, até, de entretanto assinar o diploma de 1 de Janeiro de 1210 , e depois ter-se escapado à procura da protecção pontifícia. Seja como for, uma coisa parece ser certa: a fuga para Roma deve ter-se processado entre 1 de Janeiro de 1210 (data do último diploma régio confirmado por Martinho Rodrigues) e 13 de Maio de 1210 , em que foram publicadas as bulas pontifícias nas quais o papa tomou firmes providências para sanar definitivamente o conflito e quando já Martinho Rodrigues se encontrava em Roma.

$\left(^{4}\right)$ As bulas Vehementer nos zelus e Licet Venerabilis encontram-se transcritas em Demetrio Mansilla, ob. cit., n. ${ }^{\circ} 449$ e 450, pp. 
solucionados todos os conflitos entre o rei e o clero, é difícil precisar a data de tais conflitos.

L. Gonzaga de Azevedo coloca-os em 1209 ( $\left.{ }^{41}\right)$. Alexandre Herculano situa os factos mais salientes a partir dos finais de 1209 e prolonga-os pelo ano de 1210, fazendo-os quase simultâneos dos conflitos entre D. Martinho Rodrigues e D. Sancho I $\left.{ }^{(42}\right)$.

477-480. Para a bula $S i$ te diligenter attenderes, dirigida ao rei de Portugal, vide J. Paul Migne, Patrologiae Latinae Cursus Completus, t. 216, l. XIV, col. 383, doc. VIII. Esta mesma bula foi também transcrita por Maria Alegria Fernandes Marques, na sua dissertação de licenciatura, mimeografada, apresentada à Fac. de Letras da Universidade de Coimbra, em 1974, intitulada: Alguns aspectos das relações de Portugal com a Santa Sé no pontificado de Inocêncio III, pp. 395-400 , n. ${ }^{\circ}$ 148. Contudo as três bulas vêm também publicadas, em grande parte, in Quadro Elementar, t. IX, pp. 39-45 e Summa do Bullario Portuguez, n.o* 1810-1812, pp. 277-280. Sobre alguns factos do bispo D. Pedro vide Pedro Alvares Nogueira, Livro das vidas dos bispos da Sé de Coimbra - escrito no séc. XVI - prefaciado por António Gomes da Rocha Madahil, Coimbra, 1942, pp. 66-68.

(11) Vide Luís Gonzaga de Azevedo, ob. cit., p. 43 e nota $X$, pp. 162-165, onde discorda da datação de Alexandre Herculano.

(") Alexandre Herculano, ob. cit., t. II, 1. III, p. 155. Não é fácil determinar a data dos possíveis conflitos entre o bispo e o rei. Sabe-se apenas que entre Setembro de 1207 e 10 de Agosto de 1208 , D. Pedro não confirma qualquer diploma régio e só torna a aparecer como confirmante precisamente em 10 de Agosto de 1208, isto é, 11 meses depois. $\mathbf{E}$ nestes 11 meses há 4 diplomas régios, dois dos quais são confirmados por todos os bispos, com excepção do de Coimbra, um outro diploma é apenas confirmado pelo arcebispo de Braga e o quarto não tem a assinatura de nenhum prelado, seguindo-se seis meses sem referências a qualquer diploma. Mas, tanto antes como depois daquele espaço de tempo de 11 meses, D. Pedro Soares aparece a confirmar regularmente quase durante todo o ano os diplomas régios até Maio de 1209. (Cf. Doc. Sancho I, n. ${ }^{\circ} 171$ a 176, pp. 260-268).

Depois desta data de Maio de 1209, deixa novamente de confirmar durante 19 meses, os doze diplomas régios que foram publicados, para só voltar a confirmar tais documentos a partir de 12 de Dezembro de 1210, juntamente com outros prelados, incluindo já Martinho Rodrigues, bispo do Porto. Nestes 19 meses também os outros prelados não confirmam os diplomas, com excepção da Doação à condessa D. Toda», datada de Santarém em 1 de Janeiro de 1210, isto é, passados os primeiros sete meses. Esta doação aparece confirmada por todos os prelados do seguinte modo: «Petrus Bracarensis electus et fuit, donus Martinus Portugalensis episcopus, donus Petrus, donus Nicolaus Visensis episcopus, Donus Martinus Egitaniensis, donus Suarius Elborensis episcopus». O donnus Petrus (seguido no original de um espaço em branco), é provável que seja o bispo de Coimbra. Seja como for, um tão grande espaço de tempo, mesmo admitindo aquela excepção, pode sugerir ter havido um grande contencioso entre o bispo de Coimbra e o rei (cf. Doc. Sancho I, n. 185 a 197, pp. 281-304).

Contudo, no testamento de D. Sancho I, de Outubro de 1210, afirma-se que o príncipe D. Afonso jurou nas mãos do bispo eleito 
Porém, os acontecimentos descritos nos documentos pontifícios são de tal natureza, que insinuam tensões de longa data $\left.{ }^{(3)}\right)$. E não admira que assim fosse, porque o bispo de

de Braga e do bispo de Coimbra, podendo assim entender-se que as relações com o bispo se tinham normalizado antes de Outubro de 1210. Aliás, a mesma conclusão se infere (Doc. Sancho $I$, n. ${ }^{\circ} 206$, p. 313) sobre a recepção a $D$. Martinho Rodrigues.

Sendo assim, podemos concluir que de Maio de 1209 a Outubro de 1210 (ou de 1 de Janeiro a Outubro de 1210 , caso se aceite que o donus Petrus na «Doação a D. Toda» no referido 1 de Janeiro seja o bispo de Coimbra), devem ter-se verificado as últimas e graves violências a que se referem os documentos pontifícios. A comprovar esta afirmação está ainda o facto de o novo arcebispo eleito de Braga, D. Pedro Mendes, ter sido um dos medianeiros entre o bispo de Coimbra e o rei, precisamente quando os conflitos atingiram o seu auge. Ora o novo arcebispo eleito aparece pela primeira vez como confirmante em 1 de Janeiro de 1210, o que significa que os acontecimentos violentos em que foi medianeiro só poderiam ter tido lugar próximo ou a partir daquela data, isto é, em fins de 1209 ou durante o ano de 1210 até Outubro do mesmo ano.

$O$ facto de aparecer o bispo de Braga como o único prelado testamenteiro no segundo testamento de D. Sancho em Outubro de 1210 e o único a confirmar a «Carta patente» e a «Doação ao mestre da Ordem de Santiago», respectivamente a 7 e a 9 de Dezembro de 1210, pode provar, mais uma vez, que algo de anormal ainda se passava com os outros prelados para não intervirem em documentos tão importantes. (cfr. Doc. Sancho I, n. ${ }^{\circ} 194$ a 197, pp. 297-304).

${ }^{(3)}$ Pedro Alvares Nogueira descreve certas violências que não são referidas nas bulas. Diz este autor, do século XVI, no seu Livro das Vidas dos Bispos da Sé de Coimbra, 1942, pp. 62-70 que D. Sancho I no princípio do seu reinado, se mostrou um príncipe católico, bastante devoto e amigo da Igreja, concedendo-lhe muitos privilégios a imunidades. Assim, doou à Sé de Coimbra o lugar da Covilhã com grandes liberdades. Fez aos bispos e cónegos de Coimbra bastantes mercês. Renunciou aos dizimos das Igrejas. Concedeu ao bispo e ao cabido da Sé o Castelo de Avô com toda a jurisdição e direitos, ordenando que fosse couto com todos os melhores privilégios do reino. Fez ainda doação à Sé de Coimbra do castelo de Belmonte com os padroados das Igrejas. Os cónegos tinham o privilégio de a justiça não entrar em suas casas. Os moradores do couto do cabido estavam isentos do pagamento de certas exacções. Coutou o lugar de S. Martinho do Bispo, etc.

Contudo, passado algum tempo, diz Alvares Nogueira, também sem precisar a data, que o rei começou a vexar e a perseguir, sem causa, nem razão, derribando e arrasando por terra os castelos de Avô e Coja e não permitia que os reparassem, oprimindo os moradores com pesados tributos e outros danos, impedindo-os de fugir. Tomou as propriedades na Vacariça, pertencentes à Igreja, apoderou-se de São Romão e dos casais de Freixenedo e de muitas outras terras. E quando vinha à cidade de Coimbra maltratava os clérigos, expulsava-os das suas casas e metia nelas outras pessoas, apoderava-se dos seus mantimentos e roupas, tirava-lhes os benefícios e desrespeitava os seus privilégios e imunidades. (Encontra-se também inserida neste relato 
Coimbra, conhecedor dos actos do monarca e zeloso como era da autonomia do poder espiritual e da liberdade da Igreja, não se coibia de tecer severas críticas ao comportamento de D. Sancho ${ }^{(44}$ ).

Contudo, as razões fundamentais das desavenças segundo as três bulas já referidas, são as seguintes: desrespeito pela liberdade da Igreja e usurpação da sua jurisdição pelo abuso na concessão e privação dos benefícios, aplicação das rendas eclesiásticas na manutenção dos besteiros, cães de caça, falcões e cavalgaduras; prisão dos clérigos nas cadeias públicas, fazendo-os litigar nos tribunais seculares e obrigando-os a servir no exército com graves opressões e opróbios. Além disso tomava por mau agouro e tinha por mal afortunado o dia em que topava com um clérigo ou monge, o que tudo fazia induzido por uma feiticeira que trazia consigo. Defendia os usurários, os excomungados e os inimigos da Igreja. Obrigava as viúvas que queriam observar continência a casar com os servidores da coroa e sujeitava as pessoas livres à escravidão perpétua. Proibia aos clérigos que saíssem do reino com receio

a bula de Inocêncio III, Vehementer nos zelus, de 23 de Fevereiro de 1211; vide do mesmo autor "Catálogo dos Bispos de Coimbra», in Instituições Christãs, ano VIII, 1890, Série I, n. ${ }^{\circ}$, pp. 244-246 e n. ${ }^{\circ}$, pp. 272-275).

(4) Embora D. Sancho não tivesse a corte fixa em Coimbra, fez desta cidade o seu principal centro de governo. Daí os possíveis atritos com o prelado local. Basta recordar que dos 245 diplomas régios publicados, 47 foram confirmados em Coimbra, 17 em Santarém, 59 encontram-se distribuídos diversamente por 25 localidades e. os restantes 122 não têm a designação das terras onde foram confirmados. Por isso, dado o carácter dos dois contendores era natural que tivessem surgido certos desentendimentos. (Sobre a distribuição dos diplomas pelas localidades vide Doc. Sancho I).

Alexandre Herculano refere-se a um depoimento de uma testemunha feito em 1252, por ocasião do litígio entre a Sé de Coimbra e o Mosteiro de Santa Cruz, do qual consta que o bispo D. Pedro andou exilado durante oito anos «fuit exul per octo annos». Contudo, Luiz Gonzaga de Azevedo discorda e critica esta posição. De facto há dificuldade em conciliar este depoimento com a confirmação dos diplomas régios por D. Pedro durante todo o reinado de D. Sancho I com algumas excepçóes, como por exemplo, dos documentos desde Setembro de 1207 a Agosto de 1208. Porém, outros autores defendem que os agravos com o bispo de Coimbra deviam ser antigos, pois uma das queixas do prelado era que D. Sancho obrigava os clérigos a participarem na guerra e sabe-se que nos últimos anos do seu reinado não existira qualquer guerra. Sobre toda esta questão cf. Alexandre Herculano, ob. cit., t. II, l. III, notas 181 e 182 da p. 156 e nota VII do fim do volume, p. 586; ver ainda Luís G. Azevedo, ob. cit., vol. II, pp. 162-165, e ainda Fortunato de Almeida, História da Igreja em Portugal, dir. de Damião Peres, vol. I, Barcelos, 1967, p. 170 . 
que fossem a Roma queixar-se ao papa, obrigando todos os que se ausentassem a um juramento de que não iriam à Cúria Romana, e caso faltassem, prendia-os, roubava-os e metia-os nas prisões públicas, como aliás aconteceu ao próprio bispo.

Como o prelado, seguindo ainda os documentos pontifícios, admoestasse o monarca a expulsar a feiticeira ou mulher de virtude com quem se aconselhava todos os dias, D. Sancho indignou-se com tal admoestação e procurando um pretexto para se vingar entrou numa granja ou aldeia da Igreja do bispo e pediu indevidamente aos moradores que lhe pagassem os direitos que chamavam procuração. E como o prelado recusasse pagá-los destruiu as casas que o bispo e cónegos ali tinham, tomou as cavalgaduras e saqueou a Igreja das alfaias. A tão grave violência respondeu o prelado com o interdito no bispado de Coimbra e para que o arcebispo eleito de Braga, muito afeiçoado ao rei o não pudesse levantar, apelou imediatamente para o papa $\left({ }^{45}\right)$. Quando D. Sancho soube do que se passava determinou que não se guardasse o interdito e mandou prender e confiscar os bens de todos os que o guardassem, declarando por inimigos e traidores à coroa todos aqueles que os acolhessem e auxiliassem.

0 arcebispo eleito de Braga, desejando restabelecer a paz entre os contendores e como tinha grande aceitação junto de D. Sancho, mandou chamar o bispo de Coimbra, enviando-lhe uma carta juntamente com outra do rei, prometendo-lhe que não seria objecto de nenhum agravo. Chegado a Braga, D. Pedro expôs perante o Arcebispo os motivos do interdito na diocese. $\mathrm{E}$ como lhe ordenasse que o levantasse, o prelado de Coimbra desconfiou das intenções do metropolita

(*) em 1 de Janeiro de 1210 que aparece como confirmante, pela primeira vez, o novo arcebispo eleito de Braga, muito afeiçoado ao rei e que mais tarde é o único prelado escolhido pelo monarca para seu testamenteiro e para o acompanhar nos últimos meses da sua vida. (Cfr. Alexandre Herculano, ob. cit., t. II, l. III, p. 155).

D. Pedro foi eleito arcebispo de Braga depois da morte de D. Martinho Pires que aparece a última vez como confirmante em Maio de 1209. Mas consta que nunca chegou a ser confirmado. A fim de pedir a confirmação e o pálio a Inocêncio III, mandou a Roma - tesoureiro da sua catedral, mas como se tivessem levantado dúvidas sobre o teor das bulas, não chegou a ser confirmado. Então, para o conseguir pôs-se a caminho da Cúria Romana, mas veio a falecer durante a viagem. Daí ter governado a diocese de Braga cerca de quatro anos sempre com a designação de bispo eleito como aliás se verifica em vários documentos já citados (cé. José A. Ferreira, Fastos Episcopais da Igreja Primacial de Braga, I, Braga, 1928, pp. 362-368; Fortunato de Almeida, ob. cit., vol. I, pp. 266-267. 
e não só se recusou a fazê-lo, como renovou ainda a apelação para o papa, alegando que o rei ainda não lhe tinha dado satisfação a si e ao seu clero por tantas ofensas e injustiças, mas pelo contrário, continuava a proceder como anteriormente. Então, D. Sancho, segundo descreve a bula, indignado com esta atitude do bispo, praticou novas crueldades sobre o clero que observava o interdito e se recusava a celebrar os ofícios divinos, desrespeitando as ordens do metropolita, havendo até quem dissesse que por ordem do rei arrancavam os olhos a alguns que seguiam o partido do bispo, na presença dos seus parentes e amigos, cometendo contra outros, iguais ou maiores atrocidades.

Deste modo, D. Pedro, para não ver padecer os seus súbditos inocentes, levantou o interdito resolvendo ir a Roma implorar justiça ao papa e preparou-se para sair de Portugal, mas foi preso com o seu capelão e ambos encarcerados numa prisão pública. Contudo, o capelão do bispo conseguiu fugir de noite e foi a Roma apresentar a apelação ao Papa.

Inocêncio III ordenou então, ao arcebispo de Compostela que admoestasse e obrigasse o rei a pôr em liberdade e a restituir ao prelado e aos seus clérigos quanto lhes tinham tomado, avisando-o severamente para que não tornasse a cometer semelhantes excessos $\left(^{(6)}\right.$.

Mas, como dissemos, quando a bula Vehementer nos zelus foi expedida em 23 de Fevereiro de 1211, já em Portugal estavam liquidadas as desavenças entre o rei e o clero. Por isso deve ter sido em data anterior que D. Sancho se dirigira a Inocêncio III em termos duros e pouco respeitosos ("7).

De facto, na mesma data de 23 de Fevereiro de 1211, Inocêncio III enviou também uma carta a D. Sancho I, intitulada $\mathrm{Si}$ te diligenter attenderes, repreendendo-o severamente e acusando-o de lhe ter escrito uma carta eivada de indiscrição e presunção em que se atrevera a dizer que o papa costumava prestar ouvidos a quem dizia mal do rei e não se envergonhava de soltar contra o monarca expressões indecorosas, fosse diante de quem fosse, quando os santos sucessores de S. Pedro não costumavam proferir injúrias, mas sofrê-las com paciência por amor de Cristo. Ora nenhum príncipe, continua o papa, por grande que fosse, a não ser herético ou tirano, ousou cometer o atentado de escrever tão irreverente

(“) Cf. bulas Vehementer nos zelus e Licet venerabilis, ob. cit., pp. $477-480$.

(") Alexandre Herculano, ob. cit., t. II, 1. III, p. 160, descreve pormenorizadamente esta atitude de D. Sancho. 
Q arrogantemente ao papa e aos seus antecessores, dado a honra e reverência devidas à pessoa de Cristo que representa. Mas aquilo que o rei escrevera não tinha o sabor de pureza católica, mas de perfídia herética, ao afirmar que nada melhor poderia quebrar o luxo e a soberba dos que simulavam a religião e principalmente dos prelados e do clero do que tirar-lhes a superabundância dos bens temporais que dele e do seu pai receberam com prejuízo do reino e dos seus sucessores, para os distribuir a seus filhos e aos defensores do reino que em muitas coisas padeciam necessidades. Por isso o papa o repreendia, como o pai corrige um filho a quem ama, exortando-o a não usurpar os direitos eclesiásticos, do mesmo modo que ele, Papa, não usurpava os direitos reais, e a deixar-lhe o julgamento dos clérigos, como ele lhe deixava o dos leigos. Portanto, rogava-lhe, exortava-o e aconselhava-o a que desse liberdade ao bispo de Coimbra e lhe restituisse tudo o que lhe tinha tirado, com a devida satisfação dos danos, injúrias e agravos, obstendo-se para o futuro, de cometer coisas semelhantes $\left({ }^{48}\right)$.

$\mathrm{Na}$ bula Licet venerabilis, também de 23 de Fevereiro de 1211, e dirigida ao Arcebispo de Compostela, encarrega-o de resolver a questão entre o bispo de Coimbra e o rei de Portugal, de maneira que o prelado de Coimbra viesse a obter a justiça que lhe era devida e à sua igreja. E porque lhe constava que o chanceler do rei $\left({ }^{49}\right)$ interpretava mal as letras apostólicas e as dos legados do papa, ou ocultava ao rei o que sabia que lhe desagradava, mandava ao arcebispo fizesse entregar ao monarca por um clérigo, as letras pontifícias que lhe dirigia sobre o assunto e que avisasse o chanceler, com autoridade apostólica a fim de que se abstivesse de tão iníquo procedimento para não incorrer na indignação de Deus e do papa $\left({ }^{50}\right)$.

Como se disse, as providências de Inocêncio III, relativas ao bispo de Coimbra, foram expedidas de Roma muito

( $\left.{ }^{48}\right)$ Vide $S i$ te diligenter attenderes, ob. cit., in nota 40.

(') Julião aparece em alguns diplomas com o título de mestre (Magister) e foi provavelmente um dos primeiros portugueses, como conjectura Alexandre Herculano, que frequentaram a escola de jurisprudência romana começada em Bolonha em princípios do séc. XII, pelos trabalhos de Irnério. A designação de Magister era dada aos professores de Bolonha, o que leva os autores a relacionar o chanceler Julião com a referida escola (cf. Alexandre Herculano, ob. cit., t. II, l. III, pp. 163-165; vide ainda a nota crítica n..$^{\circ} 80$ de José Mattoso, in Alexandre Herculano, ob. cit., t. II, 1. III, p. 184.

${ }^{(0)}$ Cf. bula Licet venerabilis, ob. cit., n. ${ }^{\circ} 450$, pp. 479-480. E ainda Summa do Bullario Portuguez, n. 1812 , pp. 279-280. 
posteriormente aos acontecimentos. D. Sancho, sentindo avizinhar-se a morte fizera o seu testameno em 1210 no qual contemplava generosamente o clero. E numa tentativa de conciliação tomou certas disposições relativamente à Igreja e aos prelados. Apaziguou-se com D. Pedro Soares, bispo de Coimbra e removeu os motivos que deram fundamento às desavenças entre ele e o clero, declarando que futuramente, só receberia o imposto de colheita uma vez ao ano, quando passasse pelas residências, em que era costume recolher. Além disso, tomou disposições mais gerais em defesa das imunidades eclesiásticas, para dar satisfação às queixas que o clero tinha contra ele. Daí o ter-se também reconciliado com o bispo do Porto, Martinho Rodrigues $\left({ }^{51}\right)$.

O primeiro conflito violento que surgiu no reinado de D. Afonso II e se transformou numa verdadeira guerra civil foi, precisamente, entre este monarca e as suas irmãs D. Teresa, D. Sancha e D. Mafalda.

Como já referimos, D. Sancho I, nos últimos meses que lhe restavam de vida, procedeu às suas últimas disposições, excedendo-se em generosidade e magnanimidade $\left({ }^{52}\right)$.

Porém, D. Afonso II, talvez mais aberto aos sinais da evolução histórica e política, porventura mais inserido num contexto europeu do seu tempo $\left({ }^{53}\right)$, embora não muito vocacionado para a guerra, mas fortemente cioso da sua auto. ridade $\left({ }^{54}\right)$ e do fortalecimento do poder real, revelador, até, de uma precoce centralização, não podia ser, como o antecessor, propenso a tão grandes liberalidades, nem deixar de exigir que lhe reconhecessem a soberania régia, pagassem os

$\left.{ }^{(11}\right)$ Cf. Alexandre Herculano, ob. cit., t. II, l. III, pp. 155-156; Fortunato de Almeida, ob. cit., vol. I, pp. 170-171; L. G Azevedo, ob. cit., vol. I, pp. 43-49.

$\left({ }^{62}\right)$ Cf. o segundo testamento de D. Sancho I, datado de Outubro de 1210, in Doc. Sancho I, n. ${ }^{\circ}$ 194, pp. 297-301; Monarquia Lusitana, parte IV, livro XII, cap. XXXV, pp. 61-63.

${ }^{(\omega)}$ Isto não significa que D. Sancho I não tivesse já iniciado certas medidas para fortalecer a sua autoridade e poder real. Mas tão só que em Afonso II isso passou a ser uma ideia predominante, bem patente na contenda com as suas irmãs e mais tarde com o clero.

(4) O governo de Afonso II, na opinião do Prof. Ângelo Ribeiro parece norteado por uma só ideia fixa, que é uma inovação introduzida na realidade social da época: a intangibilidade do património da coroa. Segundo este mesmo autor Portugal apresenta muito cedo essa característica fundamental do Estado Moderno que estreitamente se liga a estoutra: o engrandecimento do poder real por uma evolução centralizadora. Neste sentido chega a afirmar que Afonso II é no século XIII um excelente precursor e até uma espécie de Luís 
direitos regalengos, aceitassem os alcaides nomeados por si e lhe prestassem a devida homenagem $\left({ }^{55}\right)$.

XI. E por isso não deve ser julgado como o homem ambicioso que espolia as irmãs da herança paterna, mas o hábil e meticuloso Chefe de Estado, grandemente cioso da sua autoridade, chefe de um estado que, em pleno século XIII, apresenta já as características principais dos estados dos tempos modernos, que hão-de resultar do progressivo incremento do poder real, e, concomitantemente, do desenvolvimento dos órgãos de administração central, da criação dos impostos gerais, do estabelecimento, enfim, de uma legislação de aplicação extensiva a todo o país (Ångelo Ribeiro, $\varangle \mathrm{O}$ rei e a integridade do património da coroa», in História de Portugal, dir. por Damião Peres, vol. II, Barcelos, 1929, pp. 168 e 172; cfr. também Maria Teresa Veloso, \&A questão entre Afonso II e suas irmãs sobre a detenção dos direitos senhoriais», Revista Portuguesa de História, tomo XVIII, Coimbra, 1980, pp. 197-229.

("8) Esta parece ser a motivação que transparece dos documentos pontifícios. E não admira que assim fosse, pois Afonso II soube, durante o seu governo recorrer a homens de grande envergadura intelectual, política e diplomática, de formação europeia e conhecedores do direito romano. Destacamos mestre Julião, chanceler do reino durante trinta anos (1182 (3)-1214), provavelmente da escola de jurisprudência romana de Bolonha, que já nas relações entre D. Sancho I e Inocêncio III exercera papel relevante e fora, certamente, pela sua experiência, formação jurídica, o principal artífice da política centralizadora de Afonso II (cfr. Francisco Manuel Trigoso de Aragão Morato, Memórias sobre os chanceleres mores dos reis de Portugal», História e Memórias da Academia Real das Sciências de Lisboa, t. XII, parte II, Lisboa, 1837, pp. 95-97. Este autor apresenta-o como o 8..$^{\circ}$ chanceler do reino, único ministro que selava os diplomas, deferia as causas, tendo o terceiro lugar entre os oficiais da Casa Real, imediato ao Mordomo e ao Alferes. Cf. ainda António H. de Oliveira Marques, art. «ulião», in Dic. Hist. de Port., vol. II, pp. 642-643; A. de Jesus Costa, art. «Julião», in Encicl. Verbo, vol. II, p. 904; A. D. Sousa Costa, Mestre Silvestre e Mestre Vicente, juristas da contenda entre $D$. Afonso II e suas irmãs, Braga, 1963, pp. 68, 72 e 73, notas respectivamente 147, 151 e 152; sobre as doações a mestre Julião em virtude dos seus préstimos ao monarca (cf. Doc. Sancho I, ob. cit., n. ${ }^{\circ} 70$, pp. 107-108; n. ${ }^{\circ} 94$, pp. 150-151; n. 106, p. 168 ; n. ${ }^{\circ} 200$, pp. 306-307. Sobre o papel de Julião na política régia vide J. Mattoso, in História de Portugal, de Alexandre Herculano, tomo II, livro III, nota 80 , p. 184 em complemento ao que diz Alexandre Herculano, ob. cit., pp. 162-165; Maria Teresa Veloso, art. cit., p. 200.

Assinalamos, de igual modo, mestre Silvestre Godinho pela sua preponderante acção diplomática na Cúria Romana e mais tarde no próprio reino como arcebispo de Braga, notabilizando-se como advogado nos litígios entre o rei D. Afonso II e as suas irmãs, como noutras questōes judiciais, civis e eclesiásticas (cf. António D. Sousa Costa, ab. cit., pp. 15-54, mas principalmente pp. 37-54, onde o autor prova apoditicamente que o Mestre Silvestre se identifica com Mestre Silvestre Godinho.

Afonso II socorreu-se ainda dos préstimos de outros juristas, como Mestre Vicente, também na contenda com as suas irmãs, a quem recompensou dos serviços prestados e que mais tarde foi chanceler 
Daí que os seus irmãos D. Pedro e D. Fernando, discordantes, certamente, de tal política de evolução centralizadora, se tivessem ausentado do reino - presumivelmente por esse motivo - respectivamente para Leão e Paris. As suas irmãs, D. Teresa e D. Sancha, tivessem preferido o enfrentamento bélico. $\mathrm{E}$ alguns nobres se tivessem refugiado no reino de Leão para, em momento oportuno, desferirem os golpes de uma possível vingança $\left({ }^{58}\right)$.

Assim, talvez se entenda melhor o facto de D. Sancho I, certamente por conhecer bem o carácter, a mentalidade e a formação do príncipe herdeiro, sem excluir a grande influência dos prelados que o acompanharam nos últimos tempos da sua vida, ou por outras razões que se desconhecem, ter solicitado ao papa a confirmação e execução do seu testamento.

E na verdade, Inocêncio III, acedendo ao pedido do rei, incumbiu, pela bula Is, qui tangit montes, de 27 de Maio de 1211, o Arcebispo de Compostela, o bispo eleito de Braga e o bispo de Zamora, de fazerem cumprir o testamento do monarca $\left({ }^{57}\right)$.

Nele eram contempladas também, por D. Sancho, as suas filhas D. Teresa, ex-rainha de Leão, D. Sancha e D. Mafalda. A D. Teresa, deixara as vilas ou os castelos de Montemor-o-Velho e Esgueira. A D. Sancha, o de Alenquer ${ }^{(58)}$. E a

do rei $D$. Sancho II e ainda dos préstimos de $D$. Soeiro tanto em Roma como no reino (cf. A. D. Sousa Costa, ob. cit., pp. 27, 55-65).

Escolheu também para seu procurador em Roma mestre Lanfranco de Milão, eminente jurista, que soube também eficazmente advogar a causa do rei na Cúria Romana (cf. A. D. Sousa Costa, ob. cit., pp. $27,33-35,37,40,58,61-63,68,69,72-73,480,483,484-485$, $561-562,571,590)$.

(b) Deduz-se da bula (Licet) cum apostolo, de 31 de Agosto de 1212, transcrita in A. D. Sousa Costa, ob. cit., nota 127, p. 59; Monarquia Lusitana, parte IV, Apêndice, Escritura XXXIIII, p. 283; ref. em Summa do Bullario Portuguez, n. ${ }^{\circ} 1826$, pp. 283-284. Ainda sobre estas questões é suficientemente elucidativa a nota VIII de fim de volume de Alexandre Herculano, tomo II, p. 587. Sobre a data da saída de D. Fernando Sanches e de D. Pedro, L. G. Azevedo, ob. cit., vol. I, p. 122-126, refere o Outono de 1211. Ver notas críticas 7 e 8 de José Mattoso, in Alexandre Herculano, ob. cit., t. II, 1. IV, p. 334.

("5) Cf. bula Is, qui tangit montes, in Demetrio Mansilla, ob. cit., n. ${ }^{\circ} 454$, pp. 481-482; refer. em Augustus Pothast, ob. cit., vol. I, n. ${ }^{\circ} 4255$, p. 367. Monarquia Lusitana, Parte IV, 1. XII, c. XXXV, p. 63 verso.

(\$) Doc. Sancho I, n..$^{\circ} 194$, pp. 297-301. Cf. também Monarquia Lusitana, Parte IV, 1. XII, c. XXXV, pp. 61-63; ibidem, Apêndice, Escritura III, p. 260 v. 
D. Mafalda os mosteiros de Bouças, Arouca, Tuías e uma herdade em Seia $\left({ }^{58}\right)$.

Mas as infantas receando ou conhecendo, possivelmente, as intenções ou pretensões de seu irmão Afonso II, apressaram-se a solicitar a confirmação dos seus legados ao papa Inocêncio III, a qual lhes foi imediatamente concedida, ainda em 1211, assim como a protecção para as suas pessoas e bens, ordenando aquele mesmo pontífice aos delegados apostólicos cominassem a sentença de excomunhão contra quem ousasse molestá-las $\left({ }^{80}\right)$.

$\left.{ }^{50}\right)$ Doc. Sancho I, n. ${ }^{\circ} 194$, p. 297. Quer no testamento de D. Sancho, quer nos documentos pontifícios, não se fez alusão à vila de Aveiras que D. Sancha possuía já em vida de seu pai: «....Aaveyras, in cujus possessione fuit quiete in vita patris et etiam post mortem» (Doc. Haec sunt acta negotii, in Monarquia Lusitana, Parte IV, Apêndice, Escritura VI, p. 262 v. Este documento contém as alegações do rei e das irmãs perante os juízes apostólicos (cf. Alexandre Herculano, ob. cit., t. II, l. IV, nota 20, p. 204 e VIII, pp. 589-592.

D. Sancho no primeiro testamento, de 1188, doara a D. Mafalda as terras de Bouças, com Vila do Conde e Fão (Doc. Sancho I, n. ${ }^{\circ} 30$, p. 47; João Pedro Ribeiro, ob. cit., t. III, Apêndice, p. 122). Mas no segundo testamento de Outubro de 1210 apenas refere os mosteiros de Bouças e de Arouca e a herdade de Seia (cfr. Doc. Sancho I, n. ${ }^{\circ}$ 194, pp. 297-298). Na opinião de L. G. de Azevedo isso justifica-se porque a infanta teria, ainda em vida de D. Sancho I doado aos Hospitalários as terras designadas por aquele nome reservando para si o mosteiro de Bouças (L. G. de Azevedo, ob. cit., vol. I, pp. 58-59).

O mosteiro de Tuías é mencionado nas bulas' Ad petitionem inclite, de 7 de Outubro de 1211 e Olim ad petitionem, de 13 de Outubro de 1211 (cfr. Demetrio Mansilla, ob. cit., n. ${ }^{\circ} 457$, p. 486 e o n. ${ }^{\circ}$ 459, p. 488. O facto do mosteiro de Tuías figurar na confirmação papal dos bens de $D$. Mafalda e não no testamento de D. Sancho I, pode ser devido ao facto de a rainha o ter recebido por herança ou doação de Urraca Viegas, sua ama, e não do rei D. Sancho. (Segundo J. Mattoso, in Le monachisme ibérique et Cluny, Lovaina, 1968, pp. 47 e 150, Tuías foi fundado por Egas Moniz e habitado em 1165 pelos cónegos regulares. Depois foram substituídos antes de 1173 pelas monjas beneditinas, sob o patronato de Urraca Ibenegas; ainda do mesmo autor a nota crítica n. ${ }^{\circ} 6,1$. IV, in Alexandre Herculano, ob. cit., t. II, p. 334; vide ainda A. de Almeida Fernandes. Esparsos de História, Porto, 1970, pp. 165-167 e A Infanta-Rainha D. Mafalda, Porto, 1975 (sep. do Tripeiro, 1974), pp. 8-10 e 13.

${ }^{(\infty)}$ ) Assim, em 7 de Outubro de 1211, pela bula Ad petitionem inclite, dirigida ao arcebispo de Compostela e aos bispos de Lisboa e de Idanha confirma os bens de D. Mafalda (cf. Demetrio Mansilla, ob. cit., n. ${ }^{\circ}$ 457, pp. 486-487; Maria Teresa Veloso, art. cit., doc. 1, pp. 220-221; refer. em Augustus Pothast, ob. cit., vol. I, n. ${ }^{\circ} 4318$, p. 372.

Também em 7 de Outubro de 1211 pela bula Ad petitionem olim enviada ao arcebispo de Compostela e aos bispos de Zamora e Astorga confirma a favor de D. Teresa e de D. Sancha tudo o que seu pai lhes tinha deixado ordenando aos delegados apostólicos aplicassem censuras eclesiásticas a quem não respeitasse as suas deter- 
Contudo, apesar de todas estas diligências, o certo é que D. Afonso II não deixou de apresentar as suas reivindicaçốes sobre os bens das suas irmãs. E a primeira a ser atingida foi, precisamente, D. Mafalda.

Esta, como hábil expediente $\left({ }^{81}\right)$, ou por motivos de generosidade $\left({ }^{62}\right)$, ou por outras razões desconhecidas, doara, antecipadamente, aos freires do Hospital, o domínio de Bouças, reservando para si o usufruto $\left.{ }^{63}\right)$.

O rei reagiu fortemente contra esta doação e expulsou-os, com violência, das terras de Bouças, onde já se tinham instalado, e espoliou-os das mesmas "contra a justiça" ( $\left.{ }^{64}\right)$. Os freires apelaram para o Papa, mas Afonso II através do seu

minações (cf. Demetrio Mansilla, ob. cit., n. ${ }^{\circ} 458$, pp. 487-488; refer. em Augustus Pothast, ob. cit., n. ${ }^{\circ} 4319$, p. 372; Maria Teresa Veloso, art. cit., doc. 2 , p. 221 .

Em 13 de Outubro do mesmo ano de 1211, através da bula Olim ad petitionem memorie, e a pedido de $\mathrm{D}$. Mafalda, recebe-a sob a protecção apostólica e aos seus bens e confirma-lhe as doações e outras heranças (Demetrio Mansilla, ob. cit., n. ${ }^{\circ} 459$, p. 488; refer. em Augustus Pothast, ob. cit., n. ${ }^{\circ}$ 4324, p. 373; Summa do Bullario Portuguez, n..$^{\circ} 1816$, p. 281.

$\mathrm{E}$ ainda na mesma data de 13 de Outubro de 1211, igualmente por uma bula com a designação de Olim ad petitionem inclite, fez idêntica concessão a $D$. Teresa e a D. Sancha (cf. Demetrio Mansilla, ob. cit., n. ${ }^{\circ} 460$, pp. 488-489.

${ }^{\left({ }^{81}\right)}$ Cf. Luís G. Azevedo, ob. cit., pp. 58-60; A. Herculano, ob. cit., t. II, l. IV, p. 202; Maria Teresa Veloso, art. cit., p. 203. Segundo estes autores como a infanta tinha intenção de viver monasticamente, nada perderia, porque pouco lhe importava que fossem seus herdeiros os freires do Hospital ou a coroa. Além disso ficaria, com tal doação, mais protegida e criaria maiores dificuldades às possiveis reivindicações do seu irmão, pois caso desapossasse os freires das suas terras, estas voltariam novamente para ela.

(e2) «....conferendis buccellis et quadam alia uilla cum eorum pertinenciis in elemosinam....» (bula Dilecti filii, transcrita do Arquivo Nacional de Torre do Tombo, Gaveta 16, Maço 2, n. 15, fl. 2 v., por António Domingues de Sousa Costa, ob. cit., nota 64, pp. 26-27; vide ainda José Anastácio de Figueiredo, Nova História da Militar Ordem de Malta, Lisboa, 1800, t. I, p. 234-235).

${ }^{(\infty)}$ «.....Sibi tantum in vita sua eorum usufructu retento» (Bula Dilecti filii, in A. D. de Sousa Costa, ob. cit., nota 64, p. 26. L. Gonzaga de Azevedo é de opinião que D. Mafalda, ainda em vida de D. Sancho I, doara aos freires da Ordem do Hospital, as terras de Bouças com Vila do Conde e Fão, reservando para si o mosteiro. Tendo, porém, falecido o seu pai, D. Afonso II negou-se a ratificar a doação (cf. L. Gonzaga de Azevedo, ob. cit., p. 59; cf. Maria Teresa Veloso, art. cit., p. 206; cf. Alexandre Herculano, ob. cit., tomo II, livro IV, p. 202; A. D. de Sousa Costa, ob. cit., pp. 26 e 30).

(a) «....inductos ab eis uiolenter eiecit et eos ipsis contra iustitiam spoliavit....» (Dilecti filii, in A. D. Sousa Costa, ob. cit., nota 64, p. 26). 
procurador mestre Silvestre Godinho, presente em Roma, defendeu a nulidade de tal doação, invocando três argumentos fundamentais: 1) que D. Sancho I apenas tinha concedido a D. Mafalda o usufruto e com a condição expressa de professar a vida religiosa; 2) que o rei não estava em pleno uso das suas faculdades; 3 ) que através de um privilégio (bula Manifestis probatum) de Alexandre III se determinava que a nenhum rei de Portugal seria lícito diminuir o mesmo reino em prejuízo do seu sucessor e que a referida doação diminuiria o Reino em seis mil aureos $\left({ }^{65}\right)$.

Em 23 de Julho de 1212, por falta de provas, de parte a parte, o Papa ordenou aos Bispos de Burgos, Astorga e Segóvia que inquirissem a verdade e dessem a sentença definitiva, conforme a justiça $\left({ }^{88}\right)$.

Porém, os resultados de tal inquirição desconhecem-se. Mas uma coisa parece ser certa: a Ordem do Hospital ficou privada da doação de D. Mafalda e neste sentido o rei ganhou a questão, sem despojar a sua irmã da herança que seu pai lhe deixou, dispondo dos seus bens livremente, pois no seu testamento de 1256, refere-se às herdades de Bouças, que distingue claramente do mosteiro $\left({ }^{67}\right)$. E as relações entre ambos parecem ter melhorado, pois em 4 de Dezembro de 1217

(ङ) «....Usufructum.... et id condicione adicta si uidelicet uellet effici monialis ....compos non fuerat mentis suae ....Per felicis memorie Alexandri pape predecessoris nostri privilegium captum esse ne alicui regi Portugaliae in sucessoris preiudicium liceat minuere regnum ipsum, unde cum ex donatione hujusmodi minuatur ad valentiam VI milium aureorum» (Dilecti filii, ibidem, pp. 26-27). Neste texto faz-se uma clara referência à Bula Manifestis Probatum de Alexandre III, de 23 de Maio de 1179 e que Inocêncio III, mais tarde, em 16 de Abril de 1212, torna novamente a confirmar, a pedido de Afonso II, por uma bula com a mesma designação (Vide Monarquia Lusitana, Escritura $\mathrm{X}$, pp. 267v.-268).

Sobre a argumentação perspicaz de mestre Silvestre Godinho, sensível certamente para Inocêncio III, porque baseado nos documentos pontifícios, veja-se Angelo Ribeiro, ob. cit., p. 174; Maria Teresa Veloso, art. cit., pp. 203-206; Alexandre Herculano, ob. cit., tomo II, pp. 200-204; L. G. de Azevedo, ob. cit., pp. 58-60; A. D. de Sousa Costa, ob. cit., pp. 26 e ss.

(क) a...Quod justum fuerit» (bula Dilecti filii fratres, in A. D. Sousa Costa, ob. cit., p. 27).

${ }^{\left({ }^{07}\right)}$ \&....totam hereditatem meam de Baucis cum ipso monasterio». (Do testamento de D. Mafalda transcrito por Maria Teresa Veloso, art. cit., Apêndice, doc. 8, pp. 226-229).

Mas um problema que se levanta é saber se terá havido uma verdadeira doação aos Hospitalários ou apenas uma troca simulada. Segundo a opinião de Maria Teresa Veloso, fundamentando-se num 
- monarca coloca sob a sua protecção as pessoas e bens de D. Mafalda ( $\left.{ }^{68}\right)$.

Mas com as outras irmãs mais velhas, D. Teresa e D. Sancha, as coisas passaram-se de uma maneira diferente. Com os mesmos pretextos $\left({ }^{8 \theta}\right)$, D. Afonso recusava reconhecer-lhes o senhorio das vilas e castelos de Montemor-o -Velho, Esgueira e Alenquer, que seu pai lhes tinha legado pro hereditate $\left({ }^{70}\right)$, exigindo que lhe reconhecessem a soberania régia, lhe pagassem os direitos reais e que os alcaides daquelas terras fossem nomeados pelo monarca e lhes prestassem homenagem $\left({ }^{71}\right)$.

documento transcrito na Nova História Militar da Ordem de Malta, a infanta D. Mafalda temendo a reacção fraterna, procurou dificultar mais uma vez os intentos de seu irmão, simulando, certamente, com a Ordem do Hospital uma troca (em vez de uma doação de propriedades), o que parece inferir-se do que consta do antigo Registo do Cartório de Leça, fl. 16, col. 1: «....fazendo o n. 255 hum escambo que fez o Hospital com a rainha $D$. Mafalda em que deu à rainha a Bailia de Rio Meiaão em sa vida por quanto ela havia em Bouças .E pelo Mosteiro de S. Salvador e por Vilar de Sande.... (cf. Maria Teresa Veloso, art. cit., p. 206; José Anastácio de Figueiredo, Nova História Militar da Ordem de Malta em Portugal, Lisboa, MDCCC, pp. 234-236. O autor traduz a bula Dilecti filii, transcreve o texto acima referido e comenta-o.

${ }^{\left({ }^{88}\right)} \mathrm{O}$ documento é transcrito por Maria Helena da Cruz Coelho, $O$ Mosteiro de Arouca do século $X$ ao século XIII, Coimbra, 1977, n. ${ }^{\circ} 124$, pp. 349-350, do qual destacamos a seguinte passagem: «Sciatis quod ego recipio in mea comenda et sub mea proteccione homines et hereditates et maladias sororis mee regine domne Mahalde et quantum ipsa habet in toto meo regnos.

(o) Os argumentos que Afonso II invocou na Cúria Romana, por meio dos seus procuradores, vêm também indicados na bula ( $\mathrm{Li}$ cet) cum apostolo, de 31 de Agosto de 1212 e são idênticos aos que vêm referidos na bula já citada Dilecti filii fratres, de 23 de Julho de 1212 (cf. A. D. Sousa Costa, ob. cit., nota 127, p. 59 e nota 64, pp. 26-27).

$\left(^{70}\right)$ Doc. Sancho I, n. ${ }^{\circ} 194$, p. 297.

( $\left.{ }^{n}\right)$ Esta é a motivação que Frei António Brandão apresenta, com certa expressividade, na Monarquia Lusitana, parte IV, livro XIII, pp. 73 e 76. Aliás, é o que se deduz, igualmente, da argumentação do rei, apresentada mediante Mestre Silvestre Godinho, na Cúria Romana, inserida na bula Dilecti filii e já atrás referida. A mesma ilação se infere da bula Cum olim charissimus nas seguintes expressōes «quod praefatis sororibus dicti Regis ei iura Regalia subtrahentibus» e ainda Nobiles quoque praedicte pro castris ipsis exhiberent, sine difficultatis obstaculo iura Regalia dicto Regi, cum per patris testamentum nullatenus appareret, quod eadem a jurısdictione Regia exempta fuissent (Monarquia Lusitana, parte IV, Apêndice, Escritura VIII, pp. 264. De igual modo é a ideia que transparece da bula (Licet) cum apostolo. Escritura XXXIIII, p. 283 e ainda de toda a composição entre D. Sancho II $e$ as infantas que teve lugar em 23 de Junho de 1223, inserida na Escritura XIII, pp. 270-271. Cf. A. D. Sousa Costa, ob. cit., pp. 59-60; 34-36 e 119-123, notas 79, 127 e 221, donde consta também, que os alcaides passaram a ser nomeados pelo rei, como pretendia. 
As Infantas por sua vez, pretendiam ter, ao que parece, além da propriedade, um certo direito soberano e o exercício de toda a jurisdição sobre os bens legados $\left({ }^{72}\right)$ o que implicaria, certamente, uma independência e perpetuidade que $D$. Afonso II jamais poderia tolerar $\left({ }^{73}\right)$.

Foi, portanto, contra um certo senhorio territorial e jurisdicional $\left({ }^{74}\right)$, que o rei se insurgiu, alegando, por isso, que as suas irmãs apenas tinham o usufruto $\left({ }^{75}\right)$.

Estas parecem ter sido as razões que arrastaram à guerra civil D. Afonso e as suas irmãs D. Teresa e D. Sancha.

Antes, porém, o monarca, tendo presente o pedido de auxílio por parte de D. Afonso VIII, de Castela, contra os mouros $\left({ }^{76}\right)$, aproveitou o ensejo para demover as suas irmãs, chamando-lhes a atenção para a situação do reino e procurando uma solução pacífica. Vendo, porém, que as Infantas não se mostravam resolvidas a ceder, ordenou se procedesse às admoestações canónicas nos templos, por três vezes, a espaços de oito dias, como era do estilo. Mas, entretanto, as infantas fortificaram-se nos castelos e prepararam-se com armas, ali-

${ }^{(2)}$ Cf. Maria Teresa Veloso, art. cit., p. 203; L. G. Azevedo, ob. cit., p. 60; bula Dilecti filii, in A. D. Sousa Costa, ob. cit., p. 26.

( $\left.{ }^{73}\right)$ Cf. L. G. Azevedo, ob. cit., p. 60.

("i) E o que parece estar patente na bula Dilecti filii, principalmente nos três argumentos de Mestre Silvestre Godinho, já referidos. Sobre os direitos senhoriais que no fundo se relacionam com a presente questão, cf. António Manuel Hespanha, História das Instituições, Coimbra, 1982, pp. 138-142. O autor seguindo a historiografia actual distingue o senhorio territorial (direitos do senhor da terra enquanto «proprietário») e o senhorio jurisdicional (direitos enquanto titular de poderes soberanos ou públicos: fiscais, judiciais, militares, etc.).

( $\left.{ }^{78}\right)$ Cf. Bula Dilecti Filii.

(") O texto da bula é o seguinte: «....Nuper autem.... rex Castelle illustris contra mauros pro defensione christiani nominis profecturus ad ferendum sibi auxilium regem sollicitaret eundem, ipse prudenter statum considerans regni sui, easdem sorores suas benigna prece rogauit ut attendentes iam dictam concessionem propter raciones predictus nullius extitisse ualoris, castra sibi restituerent memorata» (Licet) cum apostolo, in A. D. Sousa Costa, ob. cit., p. 59.

Sobre a participação de Portugal e do modo como os portugueses Se houveram na célebre batalha de Navas de Tolosa são de assinalar as referências de Alexandre Herculano, ob. cit., t. II, l. IV, pp. 205-212; José Mattoso, in Alexandre Herculano, ibidem, notas 16 e 21, pp. 334-335. Na nota 21, p. 335, este autor afirma que nada prova que os participantes portugueses na batalha de Navas de Tolosa tivessem sido enviados por Afonso II. 
mentos e homens, de Portugal e de Leão, para a sua defesa $\left({ }^{77}\right)$, concedendo até em 1212 carta de foral à vila de Montemor-o-Velho talvez para conseguir o seu apoio $\left({ }^{78}\right)$.

Propôs então, D. Afonso II, numa tentativa de conciliação, que a vila fosse entregue a um fidalgo da confiança dos dois, que seria pago pelo rei e se encarregaria de entregar as rendas a $D$. Teresa. Mas $D$. Teresa não aceitou a proposta e os que se encontravam no castelo, começaram a aclamar o rei de Leão e a injuriar o de Portugal, em altos gritos $\left({ }^{79}\right)$, porque contavam com a protecção do rei leonês ao lado de quem já estavam D. Pedro, irmão do rei Português, D. Gonçalo Mendes de Sousa e os filhos de D. Teresa $\left({ }^{80}\right)$.

( $\left.{ }^{\pi}\right)$ Como se descreve na bula (Licet) cum apostolo, de 31 de Agosto de 1212, in A. D. Sousa Costa, ob. cit., p. 59: «....ipsum armis, uictualibus et personis nobilibus et ignobilibus tam ex regno Legionensi quam aliunde collectis....». cf. Monarquia Lusitana, Parte IV, Apêndice, Escritura XXXIIII, p. 283; Summa do Bullario Portuguez, ob. cit., n. ${ }^{\circ} 1826$, p. 284.

( $\left.{ }^{78}\right)$ A carta de foral foi novamente confirmada mais tarde, em 23 de Junho de 1223, por ocasião da concórdia de D. Sancho II com as infantas: «Et dominus rex promisit quod teneat homines de Monte Maiori in foro et carta quam eis dedit regina domna tharasia» (A. D. Sousa Costa, ob. cit., p. 120; Portugaliae Monumenta Historica - Leges et Consuetudines, Lisboa, 1856, p. 557-559; Monarquia Lusitana, Escritura XIIII, p. 271; Vide também Maria Teresa Veloso, art. cit., p. 208.

$\left.{ }^{70}\right)$ "....nomen Regis Legionensis invocare ceperunt in eius iniuriam alta voce» (bula (Licet) cum apostolo, in Monarquia Lusitana, Parte IV, Escritura XXXIIII, p. 283; A. D. Sousa Costa, ob. cit., p. 59; Summa do Bullario Portuguez, n. ${ }^{\circ} 1826$, p. 284.

$\left.{ }^{(80}\right)$ Bula (Licet) cum apostolo; cf. Doc. Haec sunt acta negotii, in Monarquia Lusitana, Apêndice, Escritura VI, p. 263v. E ainda L. G. Azevedo, ob. cit., p. 62 e Alexandre Herculano, ob. cit., t. II, l. IV, pp. 213-215.

Sobre os nobres que passaram para o lado de Leão, registe-se que D. Sancho I tinha escolhido para executores testamentários Pedro Afonso, Gonçalo Mendes, Martinho Fernandes, Lourenço Soares e Gomes Soares. Caso D. Afonso faltasse ao seu compromisso testamentário deveriam envidar todos os esforços para que o testamento de D. Sancho fosse cumprido. Ora sabe-se que Gonçalo Mendes de Sousa, chefe de uma das mais poderosas famílias de Portugal, e que ocupava o cargo de Mordomo-Mor do Reino, fora substituído por Martim Fernandes e abandonou a Corte, pois em Janeiro de 1211 ainda confirma o diploma da doação a «D. Herberto» (cf. Doc. Sancho I, n. ${ }^{\circ}$ 205 , p. 312) e em 5 de Dezembro de 1211 já não figura na doação a Egídio Júlio, filho do chanceler Julião, mas é substituído por Martim Fernandes novo Mordomo-Mor (Monarquia Lusitana, Parte IV, p. 68; Alexandre Herculano, ob. cit., t. II, l. IV, nota 11, p. 198 e ainda José Mattoso, in Alexandre Herculano, ob. cit., t. II, l. IV, nota 24, p. 335. Sabe-se até que em Setembro de 1211 já governava, em nome de D. Afonso IX, a Estremadura (cf. L. G. Azevedo, ob. cit., p. 54 . 
As hostilidades devem ter começado por Novembro de $1211^{\left({ }^{81}\right)}$.

O rei viu-se, então, obrigado a recorrer à força das armas e ordenou o cerco a Montemor, provocando logo a prisão de pessoas, incêndios de casas, a devastação dos campos e sementeiras, a destruição de árvores e vinhas, rebanhos, cavalgaduras, etc., a fim de enfraquecer os partidários das infantas $\left({ }^{82}\right)$.

D. Gonçalo Mendes de Sousa, que se encontrava, ao que parece, em Castelo de Torafe, correu em defesa de Montemor com os seus cavaleiros, gente de armas e peões, e travando combate com as forças de armas reduzidas de Afonso II, derrotou-as $\left({ }^{83}\right)$.

Entretanto, o rei de Leão, Afonso IX, que não só tinha recusado prestar auxílio a Castela, mas aproveitado, até, a partida do rei castelhano Afonso VIII contra os almóadas, para lhe arrebatar alguns castelos, invadiu Portugal em socorro da sua primeira mulher, a ex-rainha D. Teresa, acompanhado de D. Fernando, seu filho e de D. Teresa, e ainda do irmão desta, o Infante D. Pedro, e de D. Pedro Fernandes de Castro ( $\left.{ }^{84}\right)$.

Os invasores entraram pelo Minho e Trás-os-Montes, provavelmente em Março, ou durante o mês de Junho de $\left.1212{ }^{\left({ }^{85}\right.}\right)$, tomaram Contrasta, que foi destruída, apoderaram-

Como, portanto, era um dos que tinha feito juramento, certamente que saiu do reino e decaiu do cargo por não concordar com a política de Afonso II e por este faltar, porventura, ao cumprimento das cláusulas testamentárias.

${ }_{\left({ }^{81}\right)}$ Cf. L. G. Azevedo, ob. cit., p. 62.

${ }^{(32)}$ Do Doc. Haec sunt acta negotii, in Monarquia Lusitana, Parte IV Apêndice, Escritura VI, p. 262v.; Portugaliae Monumenta Historica - Livros de Linhagens, Scriptores, p. 201.

$\left.{ }^{\infty}\right)$ Cf. Alexandre Herculano, ob. cit., t. II, nota IX de fim do volume, pp. 592-593 e t. II, l. IV, pp. 214-215; e ainda L. G. Azevedo, ob. cit., p. 62.

(8) Cf. L. G. Azevedo, ob. cit., p. 62; Alexandre Herculano, ob. cit., t. II, l. IV, p. 214.

D. Afonso IX, rei de Leão, tinha casado com D. Teresa de quem veio a separar-se por razões canónicas e de quem tivera três filhos: D. Fernando, D. Aldonça e D. Sancha que tinham sido contemplados no testamento de D. Sancho I. Segundo Luís Gonzaga de Azevedo fez causa comum com os membros descontentes da família, invadindo - reino, e é lícito supor, que o não movia só o desejo de servir D. Teresa, mas também o de desagravar seus filhos (L. G. Azevedo, ob. cit., p. 54).

${ }^{(8)}$ Segundo a opinião de Alexandre Herculano, ob. cit., t. II, nota VIII do fim do volume, pp. 588-589, D. Afonso IX, rei de Leão, deve ter invadido Portugal, durante o mês de Junho de 1212. Porque só 
-se e espoliaram Melgaço, Lanhoso, Ulgoso $\left({ }^{86}\right)$, Balsemão, Freixo, Urros, Mós, Alvito, Sicoto. Os distritos de Barroso, Vinhais, Montenegro, Laedra, Lampazes, Miranda, Chaves, Aguiar e Panoias, foram saqueados e postos a «ferro e fogo». Afonso IX confiou um dos castelos submetidos ao Infante D. Pedro e os restantes a alcaides leoneses $\left({ }^{87}\right)$, vindo os portugueses a ser derrotados num recontro ou batalha em Valdevez $\left({ }^{88}\right)$. Transpuseram o Douro, atravessaram a Beira e vieram socorrer os defensores de Montemor $\left({ }^{80}\right)$.

Afonso II acolheu-se às muralhas de Guimarães $\left({ }^{80}\right)$ e

depois de ter atacado e tomado os castelos de Afonso VIII, rei de Castela, entrou pelo norte do país. Ora este ataque a Castela segundo este historiador, processou-se começada a expedição das Navas de Tolosa, quando Afonso VIII se encontrava empenhado na guerra contra os Muçulmainos. J. González e José Mattoso acentuam que os combatentes do exército cristão começaram a chegar a Toledo em Fevereiro de 1212. Em Maio intensificou-se a afluência, juntando-se-lhes o rei de Aragão. Em 20 de Junho de 1212 a coligação cristã saiu da cidade (cf. J. González, El reino de Castilla en la época de Alfonso VIII, I, Madrid, 1960, pp. 1010-1016) regressando Afonso VIII vitorioso da batalha, em fins de Julho de 1212 (cf. J. González, ob. cit., 1058-1061 ; J. Mattoso, notas críticas, 1, 2, 3 e 4, in Alexandre Herculano, ob. cit., t. II, p. 650). Foi neste regresso, na opinião de Alexandre Herculano, que iniciou conversaçōes de paz com Afonso IX, rei de Leão. Por isso, a invasão pela fronteira do Minho e Trás-os-Montes, dando um mês para as conquistas daqueles Castelos, desguarnecidos, havia de ocorrer, segundo o mesmo historiador, por Junho de 1212. Contudo, tanto L. G. Azevedo, como J. González são de opinião que este ataque a Portugal se deu em Março de 1212 colocando este autor a campanha contra Afonso II antes da conquista das praças castelhanas. (L. G. Azevedo, ob. cit., p. 63, nota 2; J. González, ob. cit., pp. 746-748; José Mattoso, in Alexandre Herculano, ob. cit., t. II, nt. 1-6 e 8, à nota VIII do fim do volume, pp. 650-651.

$(\infty)$ L. G. Azevedo, ob. cit., p. 63, nota 2, defende que o rei de Leão tomou Ulgoso em Março de 1212.

${ }_{\left({ }^{87}\right)}$ Toda esta questão vem pormenorizada na bula (Licet) cum apostolo, de 31 de Agosto de 1212 (Monarquia Lusitana, Apêndice, Escritura XXXIIII, p. 283 e em A. D. Sousa Costa, ob. cit., nota 127, p. 59; cf. também ref. Summa do Bullario Portuguez, n. 1826 , pp. 283-284. Sobre as destruições, violências, etc., de parte a parte, é elucidativo o documento Haec sunt acta negotii, transcrito na Monarquia Lusitana, Apêndice, Escritura VI, pp. 262-263v.).

(8) Monarquia Lusitana, parte IV, cap. V, pp. 76-78; Alexandre Herculano, ob. cit., t. II, 1. IV, p. 216; L. G. Azevedo, ob. cit., p. 63.

( $\left.{ }^{\infty}\right)$ que se depreende das bulas pontifícias já citadas: Olim al petitionem inclite, Accepimus ex litteris, Cum olim charissimus, (Licet) cum apostolo (Monarquia Lusitana, Apêndice, Escritura V. VII, VIII, XXXIIII e ainda do documento Haec sunt acta negotii, ibidem, Escritura VI, pp. 262-264 e 283; A. D. Sousa Costa, ob. cit., nota 77 , p. 32; 79, p. $34 ; 127$, p. 59 ).

(क) Sabe-se que estava em Guimarães, juntamente com o Mordomo-Mor e o chanceler Julião pela confirmação do foral do 
recorreu para o Papa, reclamando justiça não só contra o rei de Leão e as suas irmãs, mas também contra os juizes apostólicos (o arcebispo de Compostela e os bispos de Zamora e Astorga) que, entretanto, e a pedido de D. Teresa, o tinham fulminado com as censuras eclesiásticas e posto interdito no Reino de Portugal $\left({ }^{91}\right)$.

Mas dois acontecimentos acabaram por ter consequências no desfecho da complexa situação entre Afonso II e as irmãs. 0 primeiro foi a intervenção do papa em 31 de Agosto

Castelo de S. Cristóvão, em 6 de Junho de 1212 tendo-se dado já a batalha de Valdevez (Vide Portugaliae Monumenta Histórica-Leges et consuetudines, vol. I e II, doc. pp. 551-552; cf. nota. VIII de fim de volume de Alexandre Herculano, ob. cit., t. II, pp. 588-589; cf. nota crítica 6 de J. Mattoso, in Alexandre Herculano, ob. cit., t. II, p. 651).

( ${ }^{01}$ ) o que se conclui, por exemplo, da bula (Licet) cum apostolo: "Ad ipsius quoque T. Sororis suae instantiam.... protulerunt....»

O fragmento Haec sunt acta negotii, sobre a contenda entre D. Afonso II e as irmãs, não está datado. Alexíndre Herculano é da opinião que este documento deve datar-se aproximadamente dos primeiros meses de 1213 e que é uma consequência da comissão dada pelo papa aos abades de Spina e de Osseira, em Agosto de 1212, para que terminassem a contenda amigavelmente, pois caso não o conseguissem deveriam fazer subir o processo à Cúria Romana. Luís Gonzaga de Azevedo pensa que tando ficado sem efeito o breve de Inocêncio III (Licet) cum apostolo, de 31 de Agosto de 1212, foi só em 21 de Maio de 1213, pela bula Accepimus ex litteris que o processo foi cometido pelo papa aos abades de Spina e de Osseira tomando o fragmento do processo como posterior à data em que, segundo esta última bula se devia iniciar, isto é, a Septuagésima de 1214 (cf. Alexandre Herculano, ob. cit., t. II, nota VIII, p. 589; Luís Gonzaga de Azevedo, ob. cit., nota XII, pp. 169-172; J .Mattoso, nota crítica 7, in Alexandre Herculano, ob. cit., p. 651).

$\mathrm{O}$ fragmento em questão é importante porque elenca todos os prejuízos e danos causados com os cercos e as guerras entre os irmãos e faz referência a uma primeira guerra (de prima guerra 14.526 morabitinos) e de uma segunda guerra (et perde in secunda guerra 15.507 morabitinos). Luís Gonzaga de Azevedo aceita como provável a cronologia dada por Alexandre Herculano às «duas guerras» embora invocando razóes diferentes, datando o primeiro cerco de Montemor de fins de 1211 ou princípios de 1212 e que teria provocado a invasão leonesa em Março de 1212 e o segundo cerco seria depois de Novembro de 1212 e antes do breve de 21 de Maio de 1213 (cf. Luís G. Azevedo, ob. cit., p. 69 e nota XII, pp. 172-173; J. Mattoso, nota crítica 8, in Alexandre Herculano, ob. cit., t. II, p. 651; vide Haec sunt acta negotii, in Monarquia Lusitana, Escritura VI, pp. 262-263 e Alexandre Herculano, ob. cit., t. II, p. 591; (Licet) cum apostolo, in A. D. Sousa Costa, ob. cit., nota 27, p. 59; Summa do Bullario Portuguez, n..$^{\circ} 1826$, pp. 283-284; Monarquia Lusitana, Apêndice, Escritura XXXIII, p. 283; Accepimus ex litteris, in Monarquia Lusitana, Apêndice, Escritura VII, p. 263; Demetrio Mansilla, ob. cit., n. ${ }^{\circ}$ 504, pp. 545-546; refer. Summa do Bullario Portuguez, ob. cit., n. ${ }^{\circ} 1830$, pp. 286-287; A. D. Sousa Costa, ob. cit., nota 77, pp. 82-83). 
de 1212, em seguimento da apelação de Afonso II, através da bula [Licet] cum apostolo, que embora não tivesse tido efeitos imediatos, teve-os a longo prazo, como adiante referiremos. 0 segundo foi a intervenção de D. Afonso VIII, depois da vitória da batalha de Navas de Tolosa.

De facto, Afonso VIII, regressado vitorioso da batalha, em fins de Julho de 1212, em vez de exercer uma dura vingança sobre o rei de Leão, convidou-o à paz e perdoou-lhe tudo o que Afonso IX lhe tinha conquistado. Por sua vez, o rei de Leão, em virtude desse mesmo pacto, obrigava-se a entregar ao rei de Portugal, genro e aliado de Afonso VIII, todos os castelos que lhe ocupara, a fim de que, pacificados todos os reis da Península, se pudessem voltar conjuntamente, contra os sarracenos $\left({ }^{82}\right)$.

Estas tréguas entre Castela, Leão e Portugal foram assinadas, em Coimbra, no dia de S. Martinho, iso é, em 11 de Novembro de 1212 e deviam durar até 1 de Maio de 1213, data em que se devia celebrar a paz definitiva $\left({ }^{83}\right)$.

Deve, também, assinalar-se, a intervenção de Inocêncio III, a começar pela bula [Licet] cum apostolo, pela qual encar$r \in$ gou os abades de Espina e Osseira de levantarem as penas eclesiásticas, obrigando não só o rei ao juramento de que obedeceria a todas as determinações pontifícias, mas também as irmãs de que retirariam dos castelos as pessoas inimigas do rei e os entregariam a pessoas inofensivas ao monarca, devendo ambas as partes chegar a uma composição amigável. Caso não fosse possível, deveriam inquirir a verdade, comunicar os resultados ao papa e marcar um prazo para os beligerantes enviarem à Cúria Romana os seus procuradores, a fim de receberem a sentença apostólica $\left({ }^{94}\right)$.

$\left.{ }^{(82}\right)$ Cf. Luís Gonzaga de Azevedo, ob. cit., p. 68, principalmente a nota 2.

${ }^{(3)}$ «Hec est forma treuge quam fecit Rex Legionis cum Rege Castelle usque ad primam diem venturi maii in qua debet intrare Rex Portugalie.... Datum Colimbrie die Sancti Martini, confessoris» (Doc. n. ${ }^{\circ}$ 597, existente no Arquivo da Catedral de León, do respectivo Catálogo e transcrito por L. G. Azevedo, ob. cit., Doc. n. ${ }^{\circ}$ 3, pp. 191-192 e ainda pp. 68-69, nota 2; J. González, ob. cit., p. 576, doc. 900. Contudo, desconhece-se o texto de acordo assinado pela Páscoa de 1213, entre os reis de Castela e de Leão (J. González, ob. cit., pp. 149-150; J. Mattoso, in Alexandre Herculano, ob. cit., t. II, nota crítica n. 20 do l. IV, p. 335).

(a) Cf. (Licet) cum apostolo, in Monarquia Lusitana, Parte IV, Escritura XXXIIII, p. 283; A. D. Sousa Costa, ob. cit., nota 127, pp. 59-60; refer. em Summa do Bullario Portuguez, n. 1826, pp. 283-284; refer. in Demetrio Mansilla, ob. cit., n. ${ }^{\circ} 486$, p. 516. 
De facto, os legados apostólicos obedecendo às determinações pontifícias informaram o papa da sua deslocação a Portugal, e de não terem absolvido o rei, porque as infantas exigiram um lugar seguro e prazo de tempo para provar que o irmão alcançara de Inocêncio III as letras apostólicas, mediante alegações falsas, apesar do rei se ter oposto a isso, e pretender ser absolvido imediatamente, após o seu juramento, e ter pedido que toda a questão fosse submetida ao papa, pelo que a situação permanecia inalterável $\left({ }^{85}\right)$.

Contudo, tanto a concertação de paz promovida pelo rei castelhano, em 1 de Novembro de 1212 (que veio tirar, pelo menos, a protecção do rei de Leão a $D$. Teresa e a $D$. Sancha, apesar das hostilidades entre os irmãos terem, certamente, continuado), como a intervenção papal através das bulas [Licet] cum apostolo de 31 de Agosto de 1212, Accepimus ex litteris, de 21 de Maio de 1213 e outras, contribuiram, definitivamente, para uma solução de toda a questão $\left({ }^{8 \theta}\right)$.

Assim, em 21 de Maio de 1213, pela referida bula Accepimus ex litteris, depois de ouvidas as alegações de cada uma das partes, através dos procuradores, o papa ordenou aos abades de Espina e Osseira (nas dioceses de Palença e Orense), que levantassem as censuras, depois da renovação do juramento do rei, e obrigassem os contendores, sob pena de excomunhão, a tréguas seguras, que fizessem reparar os danos causados mutuamente e caso não conseguissem uma composição amigável, enviassem então para a Cúria Romana a causa suficientemente instruída para ser examinada, marcando-lhes um prazo conveniente para comparecerem na presença do papa, a fim de receberem a decisão apostólica.

Vieram, efectivamente, os abades a Portugal e absolve-

(25) o que se conclui da bula Accepimus ex litteris, de 21 de Maio de 1213. Cf. Demetrio Mansilla, ob. cit., n..$^{\circ}$ 504, pp. 545-546; A. D. Sousa Costa, ob. cit., nota 77, pp. 82-83; Monarquia Lusitana, Parte IV, Apêndice, Escritura VII, p. 263v.; M. Teresa Veloso, art. cit., pp. 222-223; refer. em Augustus Pothast, ob. cit., n. ${ }^{\circ} 4.732$, p. 411 ; refer. em Summa do Bullario Portuguez, n. ${ }^{\circ} 1.830$, pp. 286-287.

$\left.{ }^{\infty}\right)$ No entanto Alexandre Herculano, ob. cit., t. II, p. 218 e L. G. Azevedo, ob. cit., p. 69, são de opinião que Afonso II desencadeara uma nova ofensiva contra as irmãs que só veio a terminar com a imposição de tréguas por parte de Inocêncio III pela bula Accepimus ex litteris, de 21 de Maio de 1213.

L. G. Azevedo situa até a 2. ${ }^{\mathrm{a}}$ guerra civil entre as pazes de 11 de Novembro de 1212 e as tréguas ordenadas na referida bula pelo papa, em 21 de Maio de 1213. 
ram o rei no domingo da septuagésima, ou seja no dia 26 de Janeiro de $1214\left({ }^{87}\right)$.

Pela bula Cum olim charissimus, de 7 de Abril de 1216, dirigida ao bispo de Burgos e ao deão de Compostela, sabe-se que o rei, não se conformando com a obrigação de pagar cento e cinquenta mil aureos de indemnização, apelou mais uma vez para o papa, sujeitando-se novamente às censuras eclesiásticas, tendo, depois de ouvidos os procuradores de ambas as partes $\left({ }^{88}\right)$, sido absolvido das censuras e as irmãs obrigadas a pagar os direitos reais ao monarca, visto os castelos não estarem isentos da jurisdição real, nem constar do testamento qualquer isenção.

Ordenou, além disso, que as infantas entregassem os castelos aos Templários, que ficariam como que em depósito, para os conservarem em seu nome e para elas aí morarem pacificamente, mas sem prejuízo algum para o rei ou para o reino, ficando o monarca com a obrigação de as não molestar, mas sim proteger e conservar os seus direitos e que estabelecessem, definitivamente, as pazes $\left({ }^{89}\right)$.

Contudo, a sentença levou ainda tempo a concretizar-se c teve de ser, o sucessor de Inocêncio III, a pôr termo a todas as questões.

Assim, D. Teresa, ao ter conhecimento da eleição de Honório III, apressou-se a pedir a protecção apostólica para a sua pessoa e bens, o que lhe foi concedido em 13 de Novembro de 1216 pela bula Cum a nobis petitur $\left({ }^{100}\right)$.

Mas a 8 de Agosto de 1217, pela bula Cum felicis memorie, ordenou aos bispos de Burgos, Lugo e deão de Compostela para observarem o costume usado nas doaçōes feitas aos nobres, sobre os direitos reais exigidos pelo monarca $\left({ }^{101}\right)$.

(7) O Doc. com a fórmula do levantamento das censuras eclesiásticas vem transcrito em A. D. Sousa Costa, ob. cit., pp. 32-33; Monarquia Lusitana, Parte IV, 1. XIII, cap. IV, p. 74.

(8) O procurador do rei em Roma era Mestre Lanfranco de Milão e o das infantas era um certo Monge de Celanova, chamado Roberto (cfr. A. D. Sousa Costa, ob. cit., p. 34).

( $\left.{ }^{\infty}\right)$ Cfr. bula Cum olim charissimus, in A. D. Sousa Costa, ob. cit., nota 79, pp. 34-36; Monarquia Lusitana, Parte IV, Apêndice Escritura VIII, p. 264; Demetrio Mansilla, ob. cit., n..$^{\circ 49}$, pp. 573-575. O texto volta a ser repetido na bula Cum Charissimus, de 8 de Janeiro de 1218, dirigida por Honório III a Afonso II e vem transcrita em A. D. Sousa Costa, ob. cit., pp. 37-38; refer. em Augustus Pothast, ob. cit., n. 5099 , p. 448.

${ }^{(100)}$ Demetrio Mansilla, La Documentación Pontificia de Honório III, Roma, 1965 , n. ${ }^{\circ} 6$, p. 5; A. D. Sousa Costa, ob. cit., nota 80, p. 36.

( $\left.{ }^{101}\right)$ A. D. Sousa Costa, ob. cit., nota 81, p. 37; Demetrio Mansilla, ob. cit., n. 76, p. 63. 
E em 8 de Janeiro de 1218, pela bula Cum charissimus in Christo, repetiu o articulado da bula de 7 de Abril de 1216, incumbindo o bispo de Burgos de executar a sentença de Inocêncio III $\left({ }^{102}\right)$.

Entretanto, Afonso II, reclamou, por julgar suspeito o bispo de Burgos, pelo que Honório III pela bula Inter carissimum in Christo, de 23 de Maio de 1218, revogou a anterior comissão e mandou-lhes fixassem prazo de tempo para as partes enviarem os seus procuradores ao papa $\left({ }^{103}\right)$.

A questão só ficou totalmente resolvida no tempo de D. Sancho II, pela composição de 23 de Junho de 1223 . Segundo esta composição, D. Teresa e D. Sancha, possuiriam durante a sua vida o castelo de Alenquer que depois da morte de ambas deveria voltar à posse do rei de Portugal. A Infanta D. Teresa possuiria o castelo de Montemor e Esgueira que depois da sua morte passaria para $\mathrm{D}$. Branca. Porém, por morte de $\mathrm{D}$. Branca o castelo de Montemor voltaria à posse do rei de Portugal e o de Esgueira pertenceria, por herança, ao mosteiro de Lorvão.

Além disso $D$. Teresa e $D$. Sancha receberiam anualmente quatro mil maravedis que seriam pagos com os rendimentos de Torres-Vedras. Porém, a fortaleza do mesmo castelo deveria estar não mão de um vassalo do rei e deveria ter alcaidaria. Mas sempre que as rainhas pretendessem mudar c pretor, deveriam dar conhecimento disso ao rei, que, por sua vez, deveria mudá-lo.

O rei comprometia-se a respeitar e a sancionar os forais concedidos a Montemor e Alenquer pelas infantas. Mas estas ficavam obrigadas a fornecer ao rei, sempre que fosse necessário, homens de armas para o seu exército e para as anúduvas, e a fazer circular nos seus domínios a moeda real.

De toda esta composição se deduz que a soberania régia ficou fortemente assegurada, triunfando assim, de uma maneira bem clara, a solução que Afonso II preconizava $\left({ }^{104}\right)$.

As discórdias de Afonso II com o clero começaram por uma contenda entre D. Soeiro, bispo de Lisboa e o seu deão Mestre Vicente $\left({ }^{105}\right)$.

${ }^{(102)}$ A. D. Sousa Costa, ob. cit., nota 82, p. 37.

(106) A. D. Sousa Costa, ob. cit., nota 83, p. 39; Demetrio Mansilla, ob. cit., n..$^{\circ} 171$, p. 134.

$\left({ }^{104}\right)$ O texto de toda a composição vem transcrito em A. D. Sousa Costa, ob. cit., nota 221, pp. 119-123; Monarquia Lusitana, Parte IV, Apêndice, Escritura XIII, pp. 270-272.

$\left({ }^{105}\right)$ Sobre esta contenda ver Alexandre Herculano, ob. cit., t. II, 1. IV, pp. 280 e 285; A. D. Sousa Costa, ob. cit., nota 160, p. 78, onde 
Os factos vêm descritos na bula de Honório III, Nolumus preteritarum, de 25 de Outubro de 1218, dirigida ao abade e prior de Alcobaça e ao chantre de Coimbra $\left({ }^{100}\right)$, mas devem situar-se nos anos 1217-1218. Segundo este documento pontifício, cuja descrição tem presente as queixas do prelado, quando D. Soeiro partiu para a expedição de Alcácer do Sal, contra os Sarracenos, Mestre Vicente ficou a governar a diocese $\left({ }^{107}\right)$. $\mathrm{Na}$ ausência do prelado, o deão teria abusado do poder, tentando reformas que desagradaram e fora causa de prejuízos não só para o bispo, mas também para as igrejas e para o deado. Por este motivo e a instâncias do cabido, o bispo, depois de ter regressado à sua diocese, privara-o do exercício do cargo e substituira-o por outro $\left({ }^{108}\right)$. Entretanto, Mestre

vem transcrito o rescrito papal Cum inquisitiones que o autor relaciona com a animosidade de $D$. Soeiro a Mestre Vicente e ainda do mesmo autor nota $163, \mathrm{pp} .80-84$ onde se encontra na íntegra a bula Venerabilis frater de Honório III que ajuda a esclarecer a questão; cf. Luís G. Azevedo, ob. cit., pp. 98-105 sobre as possíveis causas da dissensão não só entre $D$. Soeiro e D. Afonso II relacionadas com o crescente prestígio do bispo depois da tomada de Alcácer do Sal, mas também quanto à perseguição a outros que se tinham associado à mesma expedição.

${ }^{(105)}$ A bula Nolumus preteritarum vem transcrita na íntegra em Demetrio Mansilla, ob. cit., n. ${ }^{\circ} 192$, p. 151 e em A. D. Sousa Costa, ob. cit., nota 157, pp. 76-77; ref. em Augustus Pothast, ob. cit., n. ${ }^{\circ} 5911$.

${ }^{(107)}$ Segundo A. D. Sousa Costa, ob. cit., p. 63, D. Soeiro partira para o cerco de Alcácer no estio de 1217, tendo-se dado a rendição das tropas sarracenas em Outubro de 1217. Alexandre Herculano, ob. cit., t. II, l. IV, pp. 259-270 afirma que desde a entrada dos cruzados na foz do Sado até à tomada de Alcácer haviam consumido o espaço de dois meses e meio (30 de Julho a 18 de Outubro). Luís G. Azevedo, apoiando-se nos versos de Gosuino assegura que os cercados abriram as portas de Alcácer do Sal em 21 de Outubro de 1217 (ob. cit., pp. 84-97, mas principalmente pp. 91 e 96).

$\left.{ }^{108}\right)$ Bula Nolumus preteritarum. Na opinião de Sousa Costa as relações entre D. Soeiro e Mestre Vicente deviam ser mais ou menos normais durante o ano de 1217 e princípios de 1218 e que D. Soeiro já estava na diocese nos princípios de 1218, baseando-se em diversos diplomas régios confirmados pelo bispo, como por exemplo na «Doação a Mestre Vicente», em 12 de Março de 1217, etc., e transcreve vários diplomas régios (ob. cit., pp. 66-75, principalmente a nota 144), para provar a sua opinião, defendendo ainda que a deposição de Mestre Vicente teria ocorrido depois de Abril de 1218 (ibidem, p. 76; cfr. Luís G. Azevedo, ob. cit., p. 104). Porém, existem vários diplomas de Afonso II no Arquivo Nacional da Torre do Tombo, como o «Foral de Contrasta», de 11 de Agosto, também confirmados por D. Soeiro, assim como o "Foral de Ponte de Lima» e ainda mais três diplomas durante o mês de Outubro de 1217, o que significa que a via da argumentação pelas confirmações pode não ser apodítica, pois o prelado confirma forais quando se encontrava, certamente, no cerco de Alcácer.

Contudo uma coisa parece ser certa para os diversos autores: o deão expulso já em 1220 ocupava novamente o benefício. 
Vicente, valendo-se do auxílio régio $\left.{ }^{108}\right)$, teria ocupado, à força, os bens do deado e outros bens seus e dos cónegos, embora a apelação ao papa estivesse já em curso. Foi então que o rei começou também a perseguir $D$. Soeiro e a cobri-lo de injúrias, como refere a bula, apesar do prelado the ter pedido para não se intrometer nas questões eclesiásticas $\left({ }^{110}\right)$. Além disso, o deão teria forjado as cartas de citação, atribuídas ao Arcebispo de Compostela, de que Lisboa é sufragânea, para o bispo se apresentar por si ou por outrem em Evora, onde a causa deveria ser julgada, perante o metropolita ou os seus delegados ( $\left.{ }^{111}\right)$. Em cumprimento destas, o bispo fizera comparecer em Evora, o cónego que substituira Mestre Vicente, mas que os sobrinhos deste, diz o papa, teriam ferido cruelmente $\left({ }^{112}\right)$. Citado de novo, comparecera em seu nome e com letras de proteç̧ão apostólica, Gonçalo Martins, que os homens e sobrinhos do deão deposto teriam ameaçado de morte $\left.{ }^{113}\right)$.

O bispo que procurara contrapor o poder do papa ao do rei, que favorecia Mestre Vicente apelara para o pontífice. Honório III delegou os seus poderes no abade e prior de Alcobaça e chantre de Coimbra para indagarem a verdade e resolverem definitivamente o conflito. Feita esta intervenção a discórdia cessou, tendo o deão deposto sido recondu. zido no seu cargo, terminando os clamores do cabido contra Mestre Vicente ( $\left.{ }^{114}\right)$.

$\left({ }^{10}\right)$ Bula Nolumus preteritarum. Tanto Alexandre Herculano, como A. D. Sousa Costa e L. G. Azevedo admitem a intervenção do rei (cf. Alexandre Herculano, ob. cit., t. II, l. IV, pp. 280 e ss.; A. D. Sousa Costa, ob. cit., pp. 76 e 77; Luís G. Azevedo, ob. cit., pp. 97-105. Cf. também Fortunato de Almeida, História da Igreja em Portugal, Barcelos, 1968, pp. 171-173)

(110) Bula Nolumus preteritarum, in Demetrio Mansilla, ob. cit., n. 192 , pp. 152-153.

('11) Ibidem. A. D. Sousa Costa, ob. cit., p. 78, afirma que não é muito crível a acusação relativa às letras forjadas.

("w) Bula Nolumus preteritarum. A. D. Sousa Costa, ob. cit., p. 77, levanta dúvidas se foram ou não infligidas lesões corporais e por instigação de Mestre Vicente, por falta de provas. E que o contrário é que logicamente se deveria inferir do facto da restituição do deado a Mestre Vicente a quem Honório III, logo a seguir, trata como deão de Lisboa, em 23 de Maio de 1220 (cf. ibidem, nota $158, p .77$, onde vem transcrito o documento latino). Também em Março de 1220, Afonso II o trata como deão de Lisboa, ibidem, p. 78).

(1w) Bula Nolumus preteritarum.

(14) Em 1220 já Mestre Vicente era novamente deão de Lisboa (cf. Alexandre Herculano, ob. cit., t. II, p. 283 e nota $110 ;$ A. D. Sousa Costa, ob. cit., pp. 77-78. D. Rodrigo da Cunha, História Eclesiástica da Igreja de Lisboa, Parte II, cap. 23 e fl. 119, cols. 1v. e 2; sobre as 
Também D. Afonso II entrara em conflito aberto com D. Pedro Soares, embora se desconheçam os verdadeiros motivos $\left({ }^{115}\right)$.

Pedro Alvares Nogueira, a que já fizemos referência, escreveu que D. Afonso II no princípio do seu reinado, tambám perseguiu muito o bispo de Coimbra, tendo-o preso sete meses no seu paço, sem consentir que ninguém lhe falasse, nem o servisse, pelo que passou muitos trabalhos e necessidades, pois ninguém ousava administrar-lhe o que era necessário para comer a não ser alguns clérigos, às escondidas. Mas, depois, tornou-se muito seu amigo e da clerezia e fez muito a este prelado e ao cabido no ano de $1218\left({ }^{116}\right)$.

Assim, segundo este autor, as desavenças entre o prelado e o rei teriam tido lugar antes de $1218\left({ }^{117}\right)$. Também Alexandre Herculano situa o conflito depois de D. Pedro Soares ter regressado do IV concílio de Latrão (1215), referindo que quando o prelado saiu do paço episcopal após a sua prisão pelo rei aparecera de barbas crescidas, trazendo aos ombros a cruz vermelha de cruzado, chegando a praticar actos de rematada loucura. Por tal motivo Afonso II deixou de o perseguir e o prelado submeteu-se em tudo ao próprio rei ${ }^{(118)}$.

diversas doações transcritas e onde se encontra a doação ao bispo de Lisboa na Páscoa de 1218, ver Monarquia Lusitana, Parte IV, 1. XIII, c. XVI, pp. 98-100, principalmente p. 99.

${ }^{(115)}$ t possível que as causas da perseguição estejam também relacionadas com uma certa protecção do bispo de Coimbra aos dominicanos. Alexandre Herculano insinua mesmo ter havido grande influência do espírito dominicano em D. Pedro Soares, através de Soeiro Gomes, escolhido pela ordem para propagador do novo instituto em Portugal e em que publicara certas leis contra as quais reagira D. Afonso II (Alexandire Herculano, ob. cit., t. II, l. IV, pp. 305-308 e nota XIII, p. 597; Fortunato de Almeida, ob. cit., pp. 139-140 e 174-175 afirma também que nenhum prelado como D. Pedro lhes concedera tantos privilégios).

(110) Pedro Alvares Nogueira, Livro das Vidas dos Bispos de Coimbra (escrito no século XVI), lido, prefaciado e publicado por António Gomes da Rocha Madahil, Coimbra, 1947, p. 69. Seguidamente o autor apresenta uma série de doaçōes feitas por D. Afonso II ao prelado, cabido e a outros. Refere que governou o bispado de Coimbra 40 anos, que não velava pela jurisdição da Igreja, que dissipava os bens eclesiástiros e que deixou muitas svinhas e olivais no Sidral e a pedra do uento que agora se chama o penedo das saudades» (p. 70). Alexandre Herculano regista que não foi necessário ao rei pôr guardas ao prelado. Bastou dizer um dia, apontando para a residência do bispo: «Aqui está o falcão e ali a Garça; se a Garça se mover, o falcão há-de apanhá-la» (Alexandre Herculano, ob. cit., t. II, l. IV, p. 306).

(117) Cf. Pedro Alvares Nogueira, ob. cit., p. 69.

(118) Cf. Alexandre Herculano, ob. cit., t. II, i. IV, p. 306. Esta versão condiz.com a bula Sperebamus hactenus, de Honório III, de 23 de Dezembro de 1220, em que o papa repreende o bispo de 
Sendo o clero, no tempo de Afonso II, a ordem mais poderosa do reino, não só pela sua riqueza colectiva, mas também pela coesão devida à unidade, disciplina e cultura dos seus membros, uma das principais medidas tomadas, diplomaticamente, pelo rei, foi o apaziguamento desta força portentosa, decretando nas Cortes de Coimbra, de 1211, me. didas de carácter geral, que vieram regularizar e satisfazer muitas das regalias e privilégios eclesiásticos $\left(^{119}\right)$.

Porém, em 1219, as leis que reconheceram as imunidades do clero começaram a ser violadas pelo poder civil $\left({ }^{120}\right)$. O Arcebispo de Braga, D. Estevão Soares da Silva, primeiro personagem eclesiástico do país, colocou-se à frente da defesa dos direitos da Igreja $\left.{ }^{121}\right)$.

Coimbra, por ter abandonado o Arcebispo de Braga e não se ter solidarizado com ele, desrespeitando o interdito na sua diocese (cf. A. D. Sousa Costa, ob. cit., nota 202, pp. 100-101; D. Rodrigo da Cunha, Historia Ecclesiastica dos Arcebispos de Braga, 1635, cap. XXV, pp. 110-114. Sobre a renúncia ao bispado e a não observância do interdito da diocese de Coimbra, como aconteceu por vezes e a substituição do prelado pelo papa, etc., ver também A. D. Sousa Costa, ob. cit., pp. 185-195).

(110) Sobre as deliberações tomadas nas cortes de Coimbra em 1211, vide Gama Barros, História da Administração Pública em Portugal, nos séculos XII a XV, dir. de Torquato de Sousa Soares, t. IV, Lisboa, 1945, pp. 280-281, nota 1; cf. nota crítica 2 de José Mattoso, in Alexandre Herculano, ob. cit., t. II, l. IV, p. 333. Sobre a interpretação das medidas tomadas para com o clero ver Alexandre Herculano, ob. cit., t. II, l. IV, p. 192 e ss. e ainda pp. 278-280; vide também Ângelo Ribeiro, ob. cit., pp. 171-172; Monarquia Lusitana, Parte IV, l. XIII, cap. XII e XIV, pp. 108-112, 116-118.

(120) José Augusto Ferreira, baseando-se e seguindo Alexandre Herculano, é de opinião que esta atitude de Afonso II é o resultado das ideias democráticas trazidas da Escola de Bolonha para Portugal pelo chanceler Julião (cf. José A. Ferreira, Fastos Episcopais da Igreja Primacial de Braga (séc. III-séc. XX), tomo I, Ed. da Mitra de Braga, 1928 , p. 389. Segundo Alexandre Herculano o chanceler Julião legara a Afonso II um sucessor, D. Gonçalo Mendes, imbuído também nas doutrinas da omnipotência real e da resistência à Igreja, sendo apoiado pelo mordomo-mor Pedro Anes (cf. Alexandre Herculano, ob. cit., t. II, l. III, p. 165 e l. IV, p. 286; e ainda amnota crítica 80 de José Mattoso, in Alexandre Herculano, ob. cit., t. II, l. III, p. 184, sobre as ideias de Arnaldo da Brescia que Herculano opina terem influenciado mestre Julião).

(121) Estevão Soares da Silva era filho de Soeiro Pires Escacha e de $D$. Urraca Mendes, irmã de D. Gonçalo de Souza, descendente da ilustre família dos Sylvas e dos Souzas (vide P.M.H., Nova Série, vol. I, Livros Velhos de Linhagens, ed. crítica, p. Joseph Piel e José Mattoso, Lisboa, 1980, LV-1BC8; LD-4I2, pp. 41-93; José Augusto Ferreira, ob. cit., p. 367; Avelino de Jesus da Costa, art. in Dicionário da História de Portugal, III, pp. 873-874). 
Segundo a bula Quod solite salutationis ( ${ }^{122}$ ), depois que D. Afonso II começou a exigir o tributo da colheita das Igrejas e Mosteiros, o metropolita de Braga convocou uma assembleia de prelados e outros personagens eclesiásticos e, perante todos os participantes reunidos, reprovou duramente o procedimento do rei e exortou-o a mudar de atitude para com a Igreja e a emendar-se na sua vida particular. O monarca indignou-se, reagiu e redobrou os vexames até ali praticados. O Arcebispo lançou então a excomunhão sobre os seus conselheiros e sobre o próprio rei e ainda o interdito sobre o reino. Afonso II respondeu com novas violências, mandando destruir os bens patrimoniais do Arcebispo, apoiado pelo concelho de Coimbra e vários militares. Entretanto os burgueses de Guimarães dirigiram-se a Braga e apoderaram-se dos celeiros e de todos os bens do metropolita que imediatamente excomungou os invasores $\left({ }^{123}\right)$. Estes então usaram ainda de maior violência e destruiram as granjas do arcebispo, arrasaram as vinhas, arrancaram os pomares e matas ou reduziram-nos a cinzas, vendo-se o arcebispo obrigado a deixar o reino e a refugiar-se em Roma $\left({ }^{124}\right)$.

Honório III, tomando conhesimento, expediu diversas

(122) Toda esta descrição encontra-se pormenorizada na longa bula de Honório III Quod solite salutationis, de 22 de Dezembro de 1220 e que vem transcrita em Demetrio Mansilla, La documentación pontifícia de Honório III (1216-1227), Roma, 1965, n.o 343, pp. 253-256; A. D. Sousa Costa também a transcreve na íntegra, ob. cit., nota 198, pp. 94-96 e nota 199, pp. 96-99 onde se encontra outra bula com o mesmo nome e em idênticos termos; breve ref. in Summa do Bullario Portuguez, n. ${ }^{\circ} 62$, p. 10. Ainda sobre os factos cf. A. D. Sousa Costa, ob. cit., pp. 91-109 e José A. Ferreira, ob. cit., pp. 367-407; e ainda Alexandre Herculano, ob. cit., t. II, 1. IV, pp. 287-330.

${ }^{125}$ ) \&....contra predictum Archiepiscopum et suos inique commotus, patrimoniales domos ipsius funditus per E. Velasci et homines suos M. Bigal pretorem et Concilium Colimbriensem subuerti fecisti et ad ecclesiam suam Sathane satellites uidelicet S. Suerij, M. Gonsalui milites R. Judicem M. Stephanj, J(hoanem) Petri et Concilium Vimaranense destinans Cellaria et alia bona eius, post appellationem ad sedem apostolicam.... occupasti, propter quod et in eos idem Archiepiscopus excommunicationis sententiam promulgauit....» (bula Quod solite salutationis).

(14) Segundo Alexandre Herculano, Estevão Soares partira para Roma nos princípios de 1220 (cf. Alexandre Herculano, ob. cit., t. II, 1. IV, nota 121 , p. 293.

Sobre a motivação da perseguição ao Arcebispo de Braga e à Igreja, Alexandre Herculano suspeita dever-se ao facto do rei de Leão, Afonso IX, ter concedido em Junho de 1219 a doação da vila e Couto de Ervededo, em Limia, a D. Estevão Soares, talvez devido à influência de Martim Sanches, irmão de Afonso II, exilado e bem acolhido pela corte de Leão, o que levaria o rei português a exercer 
bulas $\left({ }^{125}\right)$, procurando convencer o rei a respeitar não só as

violências sobre a Igreja (cf. Alexandre Herculano, ob. cit., t. II, l. IV, pp. 289-290; José A. Ferreira, ob. cit., p. 390. Sobre a doação da vila e do Couto de Ervededo ver Monarquia Lusitana, Parte IV, l. XIII, cap. XVII, pp. 100-102; sobre o exílio de Martim Sanches, ver Luís Gonzaga de Azevedo, ob. cit., pp. 107-108 e nota XIV, pp. 176-180; Alexandre Herculano, ob. cit., t. II, nota XII, pp. 596-597.

( $\left.{ }^{125}\right)$ Em 21 de Dezembro de 1220 expediu a bula Cum felicis memoriae retirando ao rei a comenda das Igrejas de Portugal concedida por Inocêncio III (cf. a bula em Demetrio Mansilla, ob. cit., n. ${ }^{\circ} 342$, p 253; A. D. Sousa Costa, ob. cit., nota 195, pp. 91-92; ref. Summa do Bullario Portuguez, n..$^{\circ} 1850$, p. 293). Este padroado tinha-lhe sido concedido a pedido dos bispos portugueses, através da bula Justis petentium desideriis, de 23 de Março de 1212 (cf. ref. em Summa do Bullario Portuguez, n..$^{\circ} 1823$, p. 283 e Quadro Elementar, t. IX, pp. 53-54. Também na mesma data encarregou pela bula Certantibus pro justitia os bispos de Osma e Palencia e deão desta última diocese de persuadir os prelados sufragâneos de Braga a ajudar o seu arcebispo (há uma outra bula com o mesmo nome e conteúdo, apenas com poucas diferenças, dirigida a todos os prelados sufragâneos de Braga, Abades, Priores, etc. e datada do mesmo dia e ano; cf. A. D. Sousa Costa, ob. cit., nota 196 e 197, pp. 92-93; Demetrio Mansilla, ob. cit., n. ${ }^{\circ} 341$, pp. 252-253; ref. em Summa do Bullario Portuguez, n. 1856 , pp. 295-296; ref. em Quadro Elementar, t. IX, p. 74). Em 22 do mesmo mês e ano emitiu mais duas bulas: Cum enim scias e Quod solite salutationis. A primeira é dirigida ao rei de Portugal e pede-lhe que se abstenha de perseguições e que obedeça às censuras, ameaçando-o de expor o reino à conquista dos outros reis e príncipes (Quadro Elementar, IX, pp. 75-77; breve ref. Summa do Bullario Portuguez, n. ${ }^{\circ}$ 64, p. 10; cf. José A. Ferreira, ob. cit., t. I, p. 393). Na bula Quod solite salutationis, já referida na nota 122, descreve e historia os acontecimentos que deram origem à fuga do arcebispo para Roma. Também ainda na mesma data enviou a Afonso IX, rei de Leão, a bula Cum te tanquam, pedindo-lhe defesa e protecção em favor do Arcebispo, contra Afonso II. Em 23 de Dezembro de 1220 , pela bula Ad nostram noveris, ordena igualmente aos bispos de Astorga, Orense e Tuy que admoestem o rei para que deixasse de perseguir a Igreja de Braga e não chamasse aos tribunais civis as causas do clero (cf. Demetrio Mansilla, n. ${ }^{\circ} 346$, pp. 257-258; A. D. Sousa Costa, ob. cit., nota 203, pp. 101-102; ref. em Quadro Elementar, IX, p. 78; Summa do Bullario Portuguez, n. ${ }^{\circ} 1849$, p. 293); pela bula Gravi nobis venerabilis, solicita ao bispo de Astorga e bispo e deão de Tuy que levem o rei de Portugal a respeitar as liberdades eclesiásticas (cf. Demetrio Mansilla, ob. cit., n. ${ }^{\circ} 348$, p. 259; A. D. Sousa Costa, ob. cit., nota 205, p. 103; Summa do Bullario Portuguez, n. 1859 , p. 297); através da bula Sua nobis venerabilis manda aos bispos de Astorga e de Tuy que obriguem o rei a restituir ao arcebispo de Braga os bens de que se apoderara e a jurisdição da cidade de Braga com o seu couto, terras e privilégios (como o de cunhar moeda), etc. (cf. Demetrio Mansilla, ob. cit., n. 349 , p. 260; Livro, A. D. Sousa Costa, ob. cit., nota 204, pp. 102-103); pela bula Sperebamus hactenus repreende 0 bispo de Coimbra por ter abandonado o arcebispo de Braga (cf. A. D. Sousa Costa, ob. cit., nota 202, pp. 100-101). Em 
liberdades, regalias e privilégios do clero e a não seguir alguns dos seus conselheiros, mas também a reparar e a satisfazer os prejuízos causados, sob pena de tomar medidas mais severas contra o monarca, ordenando entretanto, principalmente aos prelados sufragâneos de Braga, que se solidarizassem $\left(^{128}\right.$ ) com o arcebispo, em ordem a garantir materialmente a condigna sustentação do seu metropolita $\left({ }^{127}\right)$.

Porém, Afonso II, não cedeu e interpôs recurso para Roma, o que obrigou o papa a admoestá-lo novamente para que mudasse de comportamento e recebesse o arcebispo. E talvez esperançado na reconciliação, concedeu a Estêvão Soares a faculdade de absolver o rei e o reino de todas as censuras $\left.{ }^{128}\right)$.

4 de Janeiro de 1221 dirigiu aos bispos de Astorga, Tuy e Palência, a bula Cum nonnunqum mores, encarregando-os de aconselharem o rei a não seguir Pedro Annes e Gonçalo Mendes (cf. Demetrio Mansilla, n. ${ }^{\circ} 357$, pp. 263-264; A. D. Sousa Costa, ob. cit., nota 207, pp. 104-105; Summa do Bullario Portuguez, n. ${ }^{\circ} 1853$, p. 294; Quadro Elementar, IX, p. 79).

Em 16 de Junho de 1222 expediu mais três bulas: Ut Rex Portugalensis, Etsi Venerabili e Noveritis nos. Na primeira concedeu ao arcebispo de Braga a faculdade de absolver o reino e o rei das censuras no caso de concórdia (cf. A. D. Sousa Costa, ob. cit., n. ${ }^{\circ} 210$, p. 108, e Summa do Bullario Portuguez, n. ${ }^{\circ} 65$, p. 11); na Etsi Venerabili, dirigida a D. Afonso II exalta a humildade do arcebispo e contrasta-a com a obstinação do rei, acabando por o admoestar de que se permanecer na contumacia que excitará contra ele os Reis e os príncipes, aos quais dará o reino, desligando os súbditos do juramento de fidelidade (cf. A. D. Sousa Costa, ob. cit., nota 208, pp. 106-107; Summa do Bullario Portuguez, n. ${ }^{\circ} 1857$, p. 296; na bula Noveritis nos, ordena ao abade de Osseira e ao abade e prior de Celanova que intimem o rei e seus sequazes a desistir de perseguir a Igreja e a excomungar todos os que não se apartarem da facção do rei e que suspendam o deão da Sé de Lisboa. Mestre Vicente, o chantre do Porto e o deão de Coimbra, dos seus ofícios e benefícios, no caso de não respeitarem as suas ordens (cf. Demetrio Mansilla, ob. cit., n. ${ }^{\circ}$ 407, pp. 301-302; A. D. Sousa Costa, ob. cit., nota 209, pp. 107-108; Summa do Bullario Portuguez, n. 1858 , pp. 296-297; e ainda J. Augusto Ferreira, ob. cit., pp. 293-402; importante é também toda a nota $\mathrm{XI}$, de Alexandre Herculano, ob. cit., t. II, pp. 594-596 e nota 1 de José Mattoso, ibidem, p. 651).

${ }^{(2 *)}$ Sobre a solidariedade dos outros prelados, Honório III, em 23 de Dezembro de 1220, repreendia o bispo de Coimbra por ter abandonado o arcebispo de Braga, exortando-o a aderir ao seu partido e a assistir-lhe na perseguição (cf. A. D. Sousa Costa, ob. cit., nota 202, pp. 100-101, onde se encontra o documento na integra: Sperebamus hactenus, sobre o procedimento do prelado conimbricense).

(127) Cf. bula Certantibus pro justitia, in Demetrio Mansilla, ob. cit., n. ${ }^{\circ} 341$, pp. 252-253.

(120) Esta faculdade foi concedida ao Arcebispo de Braga pela 
Assim, em 15 de Agosto de 1222, já o arcebispo de Braga se encontrava em Portugal e reconciliado com o rei ${ }^{\left({ }^{12 \theta}\right)}$. Contudo, o agravamento da saúde de D. Afonso II e depois a sua morte em 25 de Março de 1223 (130) impossibilitou a resolução definitiva do conflito que só veio a ter plena solução com o seu sucessor D. Sancho II em Junho de 1223, através de uma concórdia constituída por duas partes. A primeira contém as promessas do rei, em relação às imunidades eclesiásticas. A segunda versa sobre a reparação dos danos infligidos às igrejas, mosteiros e ao arcebispado e igreja de Braga $e$ ainda sobre o levantamento das excomunhōes e interditos $\left({ }^{131}\right)$.

bula Ut Rex Portugalensis (cf. Summa do Bullario Portuguez, n.o 65 , p. 11 ; A. D. Sousa Costa, ob. cit., nota 210 , p. 108).

$\left({ }^{120}\right)$ Sabe-se que Mestre Vicente teve um papel importante na concórdia, pois em 15 de Agosto de 1222 já D. Estevão Soares confirmava em Santarém uma «Doação a Mestre Vicente» que o rei lhe concedera «et pro multo servicio quod nobis fecistis in pacto quod habuimus cum D. Stephano Bracarensis Archiepiscopo» (cf. Monarquia Lusitana, Parte IV, 1. XIII, cap. XXIIII, pp. 110-111v.) onde vem transcrita toda a doação).

(130) Sobre a absolvição, antes de morrer, das censuras fulminadas contra D. Afonso II, ver José A. Ferreira, Fastos Espiscopaes da Igreja Primacial de Braga, I, Braga, 1928, p. 398, nota 1 e Miguel de Oliveira, História Eclesiástica de Portugal, Lisboa, 1940, p. 92; A. D. Sousa Costa, ob. cit., pp. 116-117.

(131) Sobre a concórdia já no reinado de D. Sancho II com o arcebispo de Braga e que na opinião de Alexandre Herculano constituiu uma derrota para o partido de D. Afonso II, ver A. D. Sousa Costa, ob. cit., pp. 118-138 e 563; Monarquia Lusitana, Parte IV, 1. XIII, cap. XXIIII, pp. 110-111; Alexandre Herculano, ob. cit., t. II, l. V, pp. 349-360 e 411 .

O arcebispo de Braga, D. Estêvão Soares, tendo feito o seu testamento em Braga no dia 5 de Agosto de 1228, aditou-lhe em Trancoso, em 27 do mesmo mês, o codicilo, deixando a D. Sancho II trezentos morabitinos que antes lhe emprestara, para que não levantasse qualquer obstáculo ao cumprimento das suas últimas disposiçôes. Além disso, legara ao arcebispo, seu sucessor e ao cabido, todos os seus bens patrimoniais.

Ora uma das muitas quintas que possuia, era a de Eiras, nos arredores de Coimbra. D. Sancho, dominado pelo falso princípio, como afirma Luís G. Azevedo, de que lhe competia dispor das igrejas vagas e da propriedade eclesiástica, por morte dos respectivos pastores, mandou a um dos porteiros que tomasse conta dela e a entregasse a D. Gonçalves seu protegido. Esta violência ocasionou um litígio em que intervieram, como juízes apostólicos, D. Pedro, bispo de Lamego e o abade de Salzedas que por sua vez delegaram no chantre e tesoureiro do cabido de Coimbra e no prior do mosteiro de Santa Cruz, os quais depois de julgarem, bem fundamentada a queixa apresentada pelo cabido de Braga ao papa, obrigaram os contraditores a entregar a quinta ao cabido que, apesar de D. Estevão Soares da Silva ter morrido em Agosto de 1228, só depois de seis anos, isto é, em Novem- 
Não foi apenas com as suas irmãs e com o clero que D. Afonso II teve graves desavenças. Regista-se também durante o seu governo um outro conflito com o seu irmão bastardo Martim Sanches, com quem primeiramente parece ter vivido em boas relações ( ${ }^{132}$ ) e se encontrava em Leão, pelo menos desde 1219, onde Afonso IX o honrava entre os seus vassalos, cedendo-lhe a tenência de Toronho e Límia, em $1220{ }^{(133)}$.

Ora quando Afonso II dera ordens às autoridades de Guimarães, como referimos, para se apoderarem dos bens e celeiros de D. Estêvão Soares, arcebispo de Braga, onde quer que os tivesse, os invasores passaram a fronteira e foram apreender o que o mesmo tinha no couto de Ervededo, em terra de Límia, estando ausente Martim Sanches $\left({ }^{134}\right)$. Este, ao tomar conhecimento do sucedido, exigiu uma reparação ao seu irmão e a restituição dos bens que lhe tinham tomado no couto do arcebispo. Como não fosse atendido, entrou por

bro de 1234, entrou na sua posse (Cf. Luís G. Azevedo, ob. cit., vol. VI, p. 70. Também J. Augusto Ferreira, Fastos Episcopaes da Igreja Primacial de Braga, t. I, 1928, pp. 404-407 se refere a esta questão acrescentando que o arcebispo morrera precisamente no dia 27 de Agosto de 1228. Ver Alexandre Herculano, ob. cit., t. II, 1. V, p. 412; cfr. ainda Avelino de Jesus da Costa, art. in D. H. P., III, 873-874. D. Rodrigo da Cunha, História Eclesiástica de Braga, II, pp. 107-108.

(132) Martim Sanches era filho bastardo de D. Sancho I e de D. Maria Aires de Fornelos, o qual também foi contemplado no testamonto de seu pai, assim como a sua irmã D. Urraca Sanches: «....Et iste sunt hereditates quas dedi filiis meis quos habeo de domna Maria Arias.... Et dedi domno Martino Sancii filio meo quem habeo de illa VIII morabitinos.... et Urrace Sancii VII morabitinos» (Doc. Sancho I, n..$^{194, ~ p . ~ 298) . ~ S o b r e ~ e s t e ~ c o n f l i t o ~ e n t r e ~ D . ~ A f o n s o ~ I I ~ e ~ e s t e ~ s e u ~}$ irmão ver Monarquia Lusitana, parte IV, l. XIII, cap. VI, pp. 78-81; Luís Gonzaga de Azevedo, ob. cit., t. V, pp. 107-110 e ainda a nota XIV do mesmo volume V, pp. 176-180; Alexandre Herculano, ob. cit., t. II, l. IV, pp. 297-301 e nota XII, pp. 596-597 o qual apresenta uma interpretação um pouco diferente de Luís G. de Azevedo.

(133) Para Luís Gonzaga de Azevedo, Martim Sanches ter-se-ia retirado para Leão por causa do seu casamento com Eulália Pires, filha de Pedro Fernandes, o Castelhano, falecido em Marrocos no ano de 1214 (ob. cit., Inota 1, p. 108).

${ }^{\left({ }^{134}\right)}$ Sobre a doação da vila de Ervededo, por Afonso IX, rei de Leão, ao Arcebispo de Braga, cf. o conflito de D. Afonso II com D. Estevão Soares já relatado; também a Monarquia Lusitana, Parte IV, 1. XIII, cap. XVII, pp. 110-102 descreve tal doação; os factos estão em consonância com o que o papa relata nas bulas Quod solite salutationis e Certantibus pro justitia já citadas e referentes ao conflito entre o rei e o arcebispo (cf. Sousa Costa, ob. cit., notas 196, 198 e 199, pp. 92-98 e Demetrio Mansilla, ob. cit., n. 341 e 343, pp. 252-256).

Quanto à campanha em terras de Límia ver a descrição em Alexandre Herculano, ob. cit., t. II, l. IV, pp. 297-301 e nota XII, pp. 
terras de Portugal, por meados de 1220. Então D. Afonso II convocou a gente de guerra e dirigiu-se para Ponte de Lima, disposto a enfrentar o irmão. Porém, Martim Sanches recusou bater-se com D. Afonso II e exigiu que se retirasse para a distância de uma légua, pois não vinha fazer guerra ao reino, mas desagravar uma ofensa que portugueses lhe tinham feito e só com eles era a lide $\left.{ }^{135}\right)$. A conselho dos seus vassalos, Afonso II retirou-se para Gaia. Entre eles, figuravam Mem Gonçalves de Sousa, filho de Gonçalo Mendes, João Pires da Maia e Gil Vasques de Soverosa. Martim Sanches, embora o seu objectivo principal fosse Guimarães, pois de lá é que haviam saído os invasores, foi atraído pelos cavaleiros portugueses para a Várzea, junto de Barcelos, onde se travou a lide, ficando Martim Sanches senhor do campo, depois de ter arrancado quantos se lhe opuseram, incluindo Gil Vasques de Soverosa, seu padrasto, a quem desarmou e prendeu ${ }^{(138}$ ).

A segunda lide foi nos arredores de Braga, para o mesmo lado do mosteiro de Várzea perseguindo Martim Sanches os portugueses até Guimarães, «dando-se muitas e boas feridas e recebendo-as tanto uns como outros" $\left({ }^{137}\right)$.

A terceira lide teve lugar junto de Guimarăes, ficando

596-597; L. G. de Azevedo, ob. cit., pp. 107-110 e nota XIV, pp. 176-180 e Monarquia Lusitana, Parte IV, 1. XIII, cap. VI, pp. 78-81.

(185) Sobre quem recusou bater-se, se foi Martim Sanches ou o rei D. Afonso II, ver nota 1, de Luís G. de Azevedo, ob. cit., p. 110 e Alexandre Herculano, ob. cit., t. II, l. IV, pp. 298-299 e ainda a passagem transcrita referente a esta questão in Portugaliae Monumenta Historica-Nova Série, vol. I. Livros Velhos de Linhagens, ed. por Joseph Piel e José Mattoso, Lisboa, 1980, LD, 14 G 10, p. 171: «E este dom Martim Sanches foi casado com a condessa dona [Aure] mbiás. E este dom Martim Sanches foi muito bom e venceo a lide de Braga e de Guimarães e da Várzea, e sendo contra el poder d'el rei de Portugal todo. E este houve tão grande poder em Ponte de Lima, que quiz lidar com el rei de Portugal e todo o seu poder, e nom teve el rei que i era lide». Cf. também as notas críticas 60 e 61 de José Mattoso, in Alexandre Herculano, ob. cit., t. II, l. IV, pp. 338-339.

(196) Gil Vasques de Soverosa estava casado com D. Maria Aires de Fornelos, mãe de Martim Sanches. Consta que Martim Sanches, depois de o ter aprisionado, brindara $\rightarrow$, celebrando a valentia: já, padre, já; ca assàs lidaste! (Portugaliae Monumenta Historica, ob. cit., vol. II/I, LL 25G3, pp. 295-299; Alexandre Herculano, ob. cit., nota 127 , p. 300 ; L G. Azevedo, ob. cit., p. 110). Gil Vasques casou três vezes sendo o primeiro casamento com D. Maria Aires de Fornelos (Portugaliae Monumenta Historica, ob. cit., vol. I, LV, 1M9, p. 28; ver ainda ibidem, LD, 14 G (de F9) 10, p. 171; LV, 1 M 8, p. 28; LV, 1M, 09, p. 29; LD 13 A 3, p. 165; LD, 14 H 9, p. 171).

('17) Ibidem, LL 25 G13, p. 297; cf. Luís Gonzaga de Azevedc, ob. cit., p. 110 . 
os portugueses outra vez vencidos, tendo-se refugiado dentro dos muros do castelo. Martim Sanches, segundo a memória desta cavalaria, ficou dia e meio no campo, como era do estilo, retirando-se depois vitorioso com grandes despojos, pondo em liberdade todos os cavaleiros aprisionados ${ }^{\left({ }^{188}\right)}$.

Entre os conflitos surgidos logo no início do reinado de D. Sancho II, destaca-se o litígio de D. Soeiro Viegas, bispo de Lisboa, com o rei, mas que já se vinha arrastando desde o reinado do seu pai, pois antes da morte de D. Afonso II, ocorrida a 25 de Março de 1223, e depois da contenda com o arcebispo de Braga, isto é, pelos fins de 1222 ou princípios de 1223, foi a Roma expor ao papa as suas queixas contra D. Afonso II ${ }^{(138)}$.

Dando crédito a D. Rodrigo da Cunha $\left({ }^{140}\right)$, opinião compartilhada, ao que parece, também por José A. Ferreira ( $\left.{ }^{141}\right)$, teria sido $\mathrm{D}$. Soeiro que absolvera o rei antes de morrer das censuras fulminadas contra ele, em virtude da perseguição ao arcebispo de Braga, tendo acompanhado o cadáver até

${ }^{(138)}$ Sobre a referência da lide de Braga vide nota 135 anterior. Cf. também L. G. Azevedo, ob. cit., p. 110 , nota XIV, vol. V, pp. 176-180; Alexandre Herculano, ob. cit., pp. 297-301. A nota XIV de L. G. Azevedo é bastante esclarecedora. Este autor é de parecer diferente de Alexandre Herculano para o qual a entrada de Martim Sanches em Portugal foi o resultado do rompimento formal de hostilidades entre Portugal e Leão. Azevedo afirma que o intento de Martim Sanches estava posto no Castelo de Guimarães do qual tinha maior agravo e que a campanha não teve o aspecto de guerra de invasão e de conquista, mas de simples desforço cavalheiresco em que no fim os prisioneiros são restituídos à liberdade, conservando-se apenas o despojo ou a penhora que se fez para desagravo da represália que o rei de Portugal mandara fazer em terra estranha. Igualmente discorda da data de 1222 sendo de opinião que os factos descritos não podem ter acontecido senão por meados de 1220 , depois do rompimento formal de Afonso II com 0 arcebispo de Braga, D. Estevão Soares.

(130) Ver documento transcrito, em parte, em A. D. Sousa Costa, ob. cit., p. 113 e na íntegra, na pp. 114-116, onde há esta clara referência.

(140) Cf. D. Rodrigo da Cunha, Historia Eclesiastica da Igreja de Lisboa, Lisboa, 1642 , parte segunda, cap. XXVI, p. 120, n..$^{\circ} 6.0$ autor afirma que $D$. Soeiro assistiu sempre ao monarca e que a conselhos seus tratou el-rei de se compor com o arcebispo de Braga, pedindo perdão da contumácia contra as censuras e a absolvição que lhe foi dada. Que celebrou as suas exéquias e acompanhou o seu corpo até Alcobaça.

(14) Ver José Augusto Ferreira, ob. cit., p. 398, nota 1. 
Alcobaça, o que significa que o prelado lisbonense se encontrava em Portugal, em Março de $1223\left({ }^{142}\right)$.

Mas o que é certo é que em 12 de Abril de 1223 já D. Soeiro se encontrava novamente em Roma, no palácio papal, como consta de documento desse tempo $\left({ }^{143}\right)$.

Contudo, em Maio de 1223 devia estar novamente em Portugal porque confirma a carta régia de doação do padroado da Igreja de Soure à Ordem do Templo $\left({ }^{144}\right)$.

Em fins de 1223 vivia no exílio, como o afirma Honório III, nas letras apostólicas de 16 de Janeiro de 1224, ao arcebispo de Compostela e seus sufragâneos, ao mandar-lhes socorrer o prelado de Lisboa, a quem o rei constrangia ao exílio por se bater pelas liberdades eclesiásticas ${ }^{145}$ ).

Nestas letras apostólicas, de 16 de Janeiro de 1224,

(142) A. D. Sousa Costa refere que se atribui a aproximação entre $o$ arcebispo e o rei a diligências de $D$. Soeiro e remete, na nota 219, p. 116 para D. Rodrigo da Cunha e Frei António Brandão. Esclarece também que comumente se afirma que o prelado lisbonense absolvera o rei, antes de morrer, das censuras fulminadas contra ele, em virtude da perseguição movida ao arcebispo de Braga e que lhe celebrara as exéquias, tendo acompanhado o cadáver até Alcobaça (remetendo para Mons. J. Augusto Ferreira e Miguel de Oliveira na nota 220 , p. 117). Isso seria então, continua este autor, indício de bom entendimento entre o monarca e o bispo. Contudo, a terminar esta questão escreve: «Por ora não podemos verificar se de facto $D$. Soeiro se encontrava em Portugal ao tempo de D. Afonso II», (A. D. Sousa Costa, ob. cit., pp. 116-117 e notas 219 e 220).

${ }^{(143)}$ Cf. A. D. Sousa Costa, ob. cit., p. 112. Na nota 216, pp. 112-113 transcreve o documento pontificio em latim onde se faz referência à presença de $\mathrm{D}$. Soeiro em Roma. E na p. 134 volta este autor novamente a frisar que aquele prelado se encontrava em Roma na data referida.

(144) Cf. A. D. Sousa Costa, ob. cit., nota 240, p. 134, onde remete para ANTT, Livro dos Mestrados, fl. 57-57v, 129.

(145) Cf. A. D. Sousa Costa, ob. cit., p. 129, onde transcreve as letras pontifícias Cum frater, remetendo na nota 227 para AV, Reg. Vat. 12, fl. 140, ep. 189.

Alexandre Herculano e Fortunato de Almeida opinam que as dissensões do rei com $D$. Soeiro recomeçaram porque este prelado mal-avindo na corte por causa do seu estatuto de 1222, em que terminava se entregasse à Igreja o terço dos bens de todos os que falecessem ou pelo menos alguma porção considerável de bens sob pena de denegação dos sacramentos e da sepultura eclesiástica aos que desobedecessem, ficara sempre disposto a criar dificuldades aos governantes. Quando estes começaram a reagir contra as excessivas concessões feitas ao clero, no princípio do reinado de D. Sancho II, o prelado foi um dos primeiros a resistir, passando da sua diocese a terras de Além-Douro, onde se unira a insubmissos barões que levantavam tumultos, de modo que em 1228 já andava ausente da sua metrópole, não constando que a ela tivesse voltado antes de 1231 pois no princípio deste ano já se encontrava em Roma, pintando a Gregório IX, 
Optamus fili, vêm elencadas as queixas de D. Soeiro, salientando-se, as constantes violações dos bens e imunidades, os assaltos e saques às igrejas, a imposição do serviço militar as determinações da corte aos clérigos, a proibição de construção de igrejas, mosteiros e capelas, etc. $\left.{ }^{148}\right)$.

com as mais negras cores, as desordens do reino (Fortunato de Almeida, ob. cit., pp. 117, 138 e 179; sobre esta questão ver nota seguinte n. ${ }^{\circ}$ 146. Relativamente à ligação dos bispos aos bandos de nobres contra os mosteiros e conventos, ver Alexandre Herculano, ob. cit., t. II, $1 \mathrm{~V}$, pp. 377-378. Cf. notas críticas 47, 48 e 49 de José Mattoso, in Alexandre Herculano, ob. cit., t. II, 1. V, p. 549 onde este autor declara que ignora com que fundamento Herculano afirma que o bispo de Lisboa se foi unir aos barões de Além-Douro).

(14) Em 12 de Janeiro de 1224, Honório III incumbiu o bispo, deão e o cónego Mestre Mendo, da Sé de Lamego, pelas letras apostólicas Cum Venerabilis, de amoestarem o abade de Alcobaça, priores e outros religiosos da diocese de Lisboa, a quem, entretanto, enviava as letras papais Cum frater, a prestarem auxílio a D. Soeiro no exílio (cf. A. D. Sousa Costa, ob. cit., notas 228 e 229, pp. 129-131). Ainda no mesmo dia e ano enviou as seguintes letras apostólicas: Venerabilis frater e Gratum gerimus. Na primeira, dirigida também ao bispo, đeão e chantre de Lamego, confirma a sentença de excomunhão fulminada pelo bispo contra alguns prelados da diocese de Lisboa que não residiam nas suas igrejas, porque ocupados em seguir a corte ou outros negócios (ibidem, nota 230, p. 130). Pela segunda, enviada ao rei de Leão, louva este monarca pela proteç̧ão dispensada a D. Soeiro e a outros prelados empenhados na defesa da liberdade eclesiástica (ibidem, nota 231, pp. 130-131). No dia 13 de Janeiro, também de 1224 pelas letras apostólicas Cum venerabilis e Discretioni uestre para o deão de Lisboa, prior de Santarém e Mestre Paio, conselheiros régios e cabido lisbonense, exorta-os a colaborarem com o bispo na defesa da sua causa, sob pena de confirmar as penas que o prelado cominar contra eles, prescrevendo-lhes ainda que entregassem ao rei não só as letras apostólicas que o papa lhe enviava mas o convencessem também, como conselheiros que eram, a cumprir as ordens pontifícias (ibidem, notas 232 e 233, pp. 131-132). Também na mesma data Honório III pelas letras Venerabilis frater mandava ao bispo, deão e chantre de Viseu que fizessem observar a excomunhão e interdito lançados pelo bispo de Lisboa contra os pretores, alvazis, mordomos e outros sequazes do rei de Portugal, da diocese e cidade de Lisbaa por terem seguido o mandato régio de assaltos às igrejas (ibidem, nota 234, p. 132). A 15 de Janeiro de 1224 pelas letras Carissimis in Christo, escrevia às rainhas Dona Teresa e Dona Sancha para expulsarem de Alenquer os que, à traição, tinham assassinado o sobrinho e o mordomo do bispo de Lisboa e ajudarem este na defesa das liberdades eclesiásticas (ibidem, nota 235, pp. 132-133). E nesta mesma data dirigiu-se novamente ao deão de Lisboa, ao chanceler- mor Gonçalo Mendes, ao chantre do Porto, a Pedro Anes e Henrique Mendes, todos conselheiros régios, a exortá-los para que convencessem o monarca a satisfazer pelos danos infligidos por D. Afonso II e por ele mesmo ao clero e a desistir de perseguição que a exemplo do pai, movia ao bispo de Lisboa e que nesse mesmo sentido também escrevia ao rei, devendo eles exercer influxo salutar no ânimo juvenil do 
Em fins de 1224 e 1225 encontrava-se de novo em Portugal porque aparecem vários diplomas régios confirmados por ele $\left({ }^{147}\right)$.

Pelas letras pontifícias de 3 de Fevereiro de 1226, Honório III ordena-lhe e ao cabido que se apresentem em Roma por si ou por outrem a propósito da composição feita com o mosteiro de S. Vicente de Fora ${ }^{(148)}$.

monarca (ibidem, nota 236, pp. 133-134). Em 16 de Janeiro também de 1224, pelas letras Cum frater escrevia ao Arcebispo de Compostela e sufragâneos, ordenando que socorressem o prelado lisbonense a quem o rei constrangia ao exílio (ibidem, p. 129). E a fechar esta série de letras apostólicas dirigiu também em 16 de Janeiro de 1224 a D. Sancho II, o documento Optamus fili, onde elenca os agravos infligidos por D. Afonso II a D. Soeiro com a ameaça de o privar de qualquer direito que lhe pertencesse nas igrejas e de censuras eclesiásticas, caso se nnão dispusesse a assegurar a liberdade do prelado libonense (ibidem, p. 134 e principalmente a nota 218, pp. 114-117, onde o autor transcreve na íntegra o referido documento).

Para melhor compreensão de toda esta questão, deve salientar-se que o bispo de Lisboa, já em 12 de Abril de 1223, se encontrava em Roma, antes, portanto da morte de D. Afonso II, ocorrida a 25 de Março de 1223, onde, ao que parece, foi expor ao papa as queixas contra aquele monarca (ibidem, pp. 112-114 e o documento transcrito na nota 216 , pp. 112-113, onde se refere à presença de D. Soeiro em Roma).

Mas segundo o relato do papa Honório III a D. Sancho II, pelas letras Ojötamus fili de 16 de Janeiro de 1224, destacam-se as seguintes queixas: a proibição a D. Soeiro, sob pena de exílio, de construir mosteiros, igrejas, capelas; destruição de algumas; preferência pelos judeus nos ofícios, negação das décimas reais; privação das terças da igreja; imposição aos cristãos para transgredirem o preceito da Santa Sé de não comerciarem com os judeus; multas pecuniárias para com os fiéis que assistissem aos ofícios divinos e fizessem ofertas às igrejas construídas pelo bispo ou comerciassem com clérigos ou trabalhassem nas suas propriedades; comunicação do rei con os excomungados e proibição de se fazerem absolver; tributos aos clérigos contra as imunidades eclesiásticas e obrigação de tomarem parte no exército; assaltos frequentes às casas dos clérigos para roubarem os seus bens introduzindo nelas certas mulheres com o fim de justificarem a entrada e difamarem o clero; usurpação do direito de padroado; proibição aos arcediagos do direito de entregarem em comenda as igrejas vacantes a determinados clérigos; provisão abusiva de certas igrejas vacantes e apropriação dos proventos quando o prelado recusava a instituição canơnica; espoliação e expulsão do reino dos prelados que se the opunham na defesa da liberdade eclesiástica (ibidem, pp. 113 e 114 principalmente nota 218 , pp. 114-117, onde se transcreve todo o documento).

('17) Confirma a Carta do Couto ao Mosteiro de Tarouqueda, em Dezembro de 1224 e o foral de S. Cruz de Vilarica de 16 de Junho de 1225 e o foral de Marvão em 1226 (cfr. A. D. Sousa Costa, ob. cit., pp. $134-135$, notas 241,242 , p. 135 ).

${ }^{(146)}$ Cf. A. D. Sousa Costa, ob. cit., p. 137 e doc. da nota 248, p. 137 . 
Chamado pelo papa, e tendo-lhe o rei dado alguma satisfação, a conjecturar pelas concessões de Honório III feitas ao próprio monarca e a Mestre Vicente, trataria de se encaminhar talvez para Roma, depois de $1226\left({ }^{149}\right)$.

Depois desta data não volta a aparecer nos documentos do arquivo da Sé de Lisboa $\left({ }^{150}\right)$. Além disso parece não voltar a falar-se na questão das liberdades eclesiásticas com o bispo de Lisboa antes de 1231 ( $\left.{ }^{151}\right)$. Contudo, quando em 1231 a questão volta a tomar proporções alarmantes, pelas suas consequências, D. Soeiro estava na Cúria Papal.

Mas em 7 de Outubro de 1231, Gregório IX dirige ao bispo de Zamora e aos abades de Peleias e de S. João de Tarouca a bula Venerabilis frater, cujas disposições D. Sancho II deveria cumprir, embora seja ainda uma repercussão das queixas do prelado contra D. Afonso II. Este documento, refere-se à espoliação das décimas reais, à restituição não só dos bens no valor de 43 mil aureos, mas também das igrejas vagas com os seus rendimentos e ainda à importância de 500 aureos legados por D. Afonso II à Igreja de Lisboa e que D. Sancho retinha. Aponta ainda as opressões, as invasões de igrejas, infracções das liberdades eclesiásticas, ocupação e apropriação violentas de casas, animais, etc., e ainda o legado de $\mathbf{4 0}$ mil aureos que D. Afonso II recusava entregar. A bula termina por impor aos legados que admoestassem o monarca a desistir dos agravos infligidos ao bispo, às igrejas e ao clero e a restituir na íntegra tudo quanto lhes devia.

Seguidamente, pela bula Ex speciali, de 20 de Outubro de 1231, enviada aos bispos de Astorga e de Lugo e deão desta última sé, o papa lembra o arrombamento durante a noite das casas dos clérigos que tentavam difamar, a pretexto de uma constituição de D. Afonso Henriques sobre a captura de mulheres encontradas com clérigos, os roubos dos seus bens, as ocupações de igrejas e dos bens da catedral, a preferência dos judeus aos cristãos nos ofícios públicos, a imposição aos clérigos do serviço militar, das anúduvas e atalaias, etc.

(199) Vide A. D. Sousa Costa, ob. cit., p. 138. O seu nome aparece a última vez no foral de Marvão em 1226. Cfr. Alexandre Herculano, ob. cit., t. II, doc. 20 , p. 609 .

${ }^{300}$ ) Cf. A. D. Sousa Costa, ob. cit., p. 138. D. Rodrigo da Cunha, Historia Eclesiastica da Igreja de Lisboa, parte segunda, Lisboa, 1642 , cap. XXVI, p. 120v., n. ${ }^{\circ}$, afirma: «Não saberemos dizer o fim que teve este negócio e se com efeito tornou o bispo para sua igreja, o certo é, que sendo isto no princípio do ano de 1226, até o de 1231, nos faltam memorias suas neste cartório......

(191) Cf. A. D. Sousa Costa, ob. cit., p. 137. 
A bula termina dando poderes aos delegados para recorrerem às censuras eclesiásticas a fim de assegurarem a incolumidade do prelado na sua pessoa e bens. Segue-se outra bula também intitulada Venerabilis frater, mas datada de 11 de Novembro de 1231, dirigida ao abade de S. João de Tarouca e ao deão de Zamora, para tomarem conta das igrejas vacantes de Lisboa. Finalmente, em conformidade com a bula Ex speciali, foi lançado o interdito nos lugares onde o rei chegasse, mas esta censura eclesiástica, ao que parece, foi recebida com grandes violências.

Porém, D. Soeiro, certamente assegurado pelas promessas do rei, devia ter regressado a Portugal, depois destes acontecimentos, pois a sua assinatura já aparece no foral do Crato, datado de 22 de Março de $1232{ }^{(152)}$.

O conflito entre Martinho Rodrigues e a realeza reacendeu-se com D. Sancho II nos últimos meses de $1226\left({ }^{103}\right)$.

(152) Sobre os acontecimentos em 1231-1232, ver A. D. Sousa Costa, ob. cit., pp. 138 e 179-196.

As três bulas Venerabilis frater, Ex speciali e Venerabilis frater, vêm transcritas integralmente também em A. D. Sousa Costa, ob. cit., respectivamente nas notas 296 j, 298 e 299, pp. 180-185.

Quanto ao interdito de 1231 que teria sido recebido com grandes violências, ver L. G. Azevedo, ob. cit., vol. VI, pp. 45-49. Este autor é de opinião que depois do interdito o primogénito do rei de Castela, futuro D. Afonso X, entrara com gente armada, pela comarca de Braga, acompanhado por dois fidalgos, João Fernandes de Lima e Rodrigo Froilaz, tendo sido excomungados pelo arcebispo D. Silvestre Godinho e que alguns morreram em combate não recebendo sepultura em sagrado. Para o mesmo autor, tal entrada, para defesa de D. Sancho II, seria inexplicável sem um novo levantamento dos fidalgos contra ele, repetindo-se, assim, em 1231-1232 as cenas passadas em Elvas, em 1226.

$\left.{ }^{(10}\right)$ Sobre a data cf. Luís Gonzaga de Azevedo, ob. cit., vol. VI, p. 22; Alexandre Herculano, ob. cit., p. 381; A. D. Sousa Costa, ob. cit., pp. 139-158, onde se encontra suficiente documentação que ilustra a presente questão. Para a descrição do reino antes do litígio com Martinho Rodrigues e violências sobre as ordens monásticas ver a bula Non absque dolore, de 18 de Dezembro de $1226 \mathrm{em}$ breve ref. na Summa do Bullario Portuguez, n. 74 , p. 12; Alexandre Herculano, ob. cit., t. II, l. V, pp. 375-383; e ainda as bulas Cum sicut, Auctoritate vobis e Omnes questiones sobre as questões do Mosteiro de S. Vicente de Fora com D. Soeiro, bispo de Lisboa, em A. D. Sousa Costa, ob. cit., notas 248, pp. 137-138 e 296, pp. 169-170. Alexandre Herculano (ob. cit., t. II, l. V, pp. 378-390), seguido por Fortunato de Almeida (ob. cit., vol. I, pp. 177-178), José Augusto Ferreira (Memórias Archeologico - Historicas da Cidade do Porto, vol. I, Braga, 1923, p. 22), Ângelo Ribeiro (ob. cit., pp. 211-215 e 225-228) e outros enquadra estas desavenças num contexto a que não fora indiferente 
Assim, em 16 de Março de 1221, pela bula Venerabilis frater, Honório III revogara a pedido de D. Martinho Rodrigues certas comendas das igrejas da diocese do Porto, proibindo ao monarca de se intrometer no assunto, enquanto não

\begin{abstract}
a anarquia durante a menoridade de D. Sancho II, a qual não se limitara apenas à nobreza, mas invadira o próprio clero com a intervenção dos prelados nas facções políticas e associação dos bandos de nobres que, atraídos pelos proventos das ordens monásticas, fizeram dos mosteiros e conventos as suas principais vítimas, juntando ainda a estas razões a questão das doutrinas acerca dos limites do sacerdócio e império, herdadas dos governos anteriores e presentes nos conselheiros do rei, sem esquecer Mestre Vicente, seu novo chanceler, repercutindo-se, tudo isto, nas contendas levantadas entre o bispo do Porto e o monarca. (De facto Herculano afirma que Martinho Rodrigues andara envolvido nos distúrbios civis de que o reino havia sido teatro (ob. cit., t. II, l. V, p. 381). Contudo o recontro de Crasconho, por exemplo, e não Transconho (cf. nota crítica 21 de José Mattoso, in Alexandre Herculano, ob. cit., t. II, l. V, p. 546) a que Herculano se refere para provar a sua asserção, deve situar-se, como prova L. G. Azevedo (ob. cit., vol. VI, pp. 166-169) no reinado de D. Sancho I e não de Sancho II (cf. também nota crítica 22 de José Mattoso, in Alexandre Herculano, ob. cit., t. II, l. V, p. 546). E quanto à sua opinião de que $\mathrm{D}$. Soeiro se juntou aos baróes de Além Douro (ibidem, p. 414) também não se conhecem os fundamentos desta sua tese (cfr. nota crítica 47 de José Mattoso, in Alexandre Herculano, ibidem, p. 549); cf. Ângelo Ribeiro, ob. cit., pp. 211-215 e 225-228. Relativamente a Mestre Vicente foi nomeado chanceler do reino em 1224 (cf. nota crítica 19, de José Mattoso, in Alexandre Herculano, ob. cit., t. II, l. V, p. 546 e A. D. Sousa Costa, ob. cit., pp. 448).

Para Luís Gonzaga de Azevedo (ob. cit., vol. VI, pp. 22-23 e 141-151, o motivo principal da discórdia não foi uma questão pessoal, mas por causa do domínio que à Igreja do Porto competia sobre a principal cidade do reino e que a coroa procurava forçosamente conquistar, mas que a Igreja defendia com bons fundamentos e com sucessivos apelos à autoridade dos papas, que muitas vezes examinaram e confirmaram o valor desses diplomas. Assim, a defesa das imunidades na cidade do Porto, agravava-se e complicava-se quando em 1226 se desvaneceram as esperanças de um novo governo presidido por D. Afonso (Conde de Bolonha) que depois de uma breve guerra civil foi vencido e lançado fora do reino (vide nota infra 233). Martinho Rodrigues apresentou perante Honório III importantes queixas contra o soberano, precedidas, ao que parece, das censuras de excomunhão e interdito, lançados por ele. (Este autor defende que as tensões originadas e agravadas depois da expedição a Elvas deram origem a uma primeira guerra civil, contudo os argumentos em que se baseia parecem não ser muito claros e suficientemente seguros como se refere as notas críticas 18 e 20 de José Mattoso, in Alexandre Herculano, ob. cit., t II, l. V, pp. 545-546). Ainda sobre Martinho Rodrigues, A. D. Sousa Costa, ob. cit., p. 142, oferece-nos um conjunto de documentos que vêm a ajudar a esclarecer alguns pontos da presente questão, opinando que talvez nas intervençóes do papa se esconda o resquício que nos fins de 1226 veio a atear o incêndio.
\end{abstract}


fosse requerido pelo prelado, já que a sua intromissão fora causa de muitos agravos para com essas igrejas ( ${ }^{154}$ ).

Em 3 de Abril de 1224 o papa confirmava pela bula Justis petentium a doação dos dízimos dos proventos e réditos reais, feita pelo rei de Portugal à diocese do Porto $\left({ }^{165}\right)$.

A 4 de Janeiro de 1227, a pedido insistente do bispo do Porto, o papa proibia pela bula Cum a nobis petitur, a quem quer que fosse, absolver, antes da devida satisfação, os clérigos e leigos da diocese, da excomunhão e interdito, fulminados pelo bispo, por causa dos vexames cometidos contra ele e a sua igreja pelo rei e sequazes $\left({ }^{158}\right)$.

A 18 de Janeiro do mesmo ano, Honório III, pela bula Cum causam, dirigiu-se ao bispo, deão e chantre de Zamora, cometendo-lhes a causa da jurisdição da cidade do Porto, os seus dízimos e outros assuntos, que pendiam entre o prelado e o monarca, ordenando-lhes ainda que se porventura D. Martinho Rodrigues tivesse de residir fora de Portugal lhe fizessem entregar os rendimentos e impedissem os homens do rei de exercerem qualquer jurisdição ou poder na cidade do Porto, que pertencia à igreja portuense por doação da rainha D. Teresa $\left({ }^{157}\right)$.

Porém, na mesma data, envia-lhes a bula Carissimus in Christo, onde descreve, pormenorizadamente, os vexames infligidos ao bispo e à cidade pelo monarca $\left(^{158}\right)$.

Entre as principais queixas expostas na bula Carissimus in Christo e ainda, embora sucintamente, na bula Cum causam, ambas datadas como referimos, de 18 de Janeiro de 1227, relevam-se as seguintes: usurpação da jurisdição episcopal na cidade; obrigação dos cidadãos ao serviço militar como se fossem homens seus e prisão dos mesmos, impondo-lhes pesadas multas; agravamento com exacções indevidas; imposição e exigência de procurações; disposição ilegítima das igrejas pertencentes ao bispo; apresentação de sujeitos em algumas delas, invocando um padroado que não tinha; coacção dos clérigos a servirem no exército; negação do pagamento dos dízimos; sujeição dos seus cidadãos e pessoas eclesiásticas

(154) A. D. Sousa Costa, ob. cit., p. 142. Sobre esta proibição ver bula Venerabilis frater, transcrita, ibidem, na nota 215 , p. 112.

(1w) Ibidem, p. 142. Bula Justis petentium, transcrita na nota 244, p. 135.

(10) Ibidem, pp. 142-143. Bula Cum a nobis petitur, in nota 260 , p. 143. pp. 144-145.

(157) Ibidem, p. 143. Bula Cum causam, in nota 261, p. 143.

${ }^{\left({ }^{16 s}\right)}$ Ibidem, p. 144. Bula Carissimus in Christo, in nota 262, 
a responderem perante o foro secular. $O$ papa termina por ordenar aos delegados apostólicos, a quem a bula é dirigida (bispo, deão e chantre de Zamora), que se o monarca não restituisse ao prelado e ao cabido tudo o que lhe pertencia ouvissem as partes e obrigassem a execução do que fosse justo por meio de censuras eclesiásticas $\left({ }^{150}\right)$. E na bula Cum causam manda ao bispo e deão de Zamora que todos os rendimentos lhe sejam entregues e que proibam às justiças do rei exercer qualquer jurisdição na cidade do Porto e mande mostrar ao rei as letras da Santa Sé sobre a questão $\left({ }^{160}\right)$.

Contudo, o papa, simultaneamente com estas letras apostólicas, es乞reveu no mesmo dia e no mesmo teor ao rei D. Sancho II, dando-lhe conhecimento destas queixas e ameaçando-o de intervir com mais dureza caso não respeitasse a jurisdição do prelado e não restituisse os bens sequestrados $\left({ }^{161}\right)$.

Entretanto, o papa Honório III morreu a 18 de Março de 1227 e a questão só ficou resolvida no pontificado do seu sucessor Gregório IX, que imediatamente se interessou pelo problema, dirigindo ao bispo e cabido da Sé do Porto, e a pedido destes, em 5 de Abril de 1227, a bula Justis petentium desideriis, a confirmar a doação do burgo portucalense feita à igreja $\left({ }^{162}\right)$.

Em 5 de Maio, também de 1227, enviou as bulas Scire debes e Cum causam. Na primeira dirigia-se ao rei reprovando energicamente a sua atitude para com as igrejas, sendo uma repetição, quase ipsis verbis, das queixas expostas nas letras de Honório III, Carissimus in Christo $\left({ }^{163}\right)$.

$\mathrm{Na}$ bula Cum causam refere-se à comissão da causa sobre a jurisdição da cidade, às décimas e a outras questões, dando aos delegados apostólicos certas instruções semelhantes às bulas anteriores $\left({ }^{164}\right)$.

Em fins de 1227 chegou a Portugal, como delegado do papa Gregório IX, João de Abbeville, homem de grande prestígio na igreja, cuja influência, em toda a Península, foi notável, tendo sido constantemente citada por documentos ecle-

(159) Bulas Carissimus in Christo, e Cum Causam, in Demetrio Mansilla, ob. cit., n. ${ }^{\circ} 624$ e 623, pp. 472-475; A. D Sousa Costa, ob. cit., n. 262 , pp. $144-145 ;$ n..$^{\circ} 261$, p. 143.

p. 473.

$\left.{ }^{(100}\right)$ Bula Cum causam, in Demetrio Mansilla, ob. cit., n. ${ }^{\circ} 623$,

(181) Bula Cum carissimus in Christo, in Demetrio Mansilla, ob. cit., n. ${ }^{\circ} 624$, p. 475.

(182) A bula Justis petentium vem transcrita em A. D. Sousa Costa, ob. cit., nota 269 , p 149.

$\left({ }^{103}\right)$ Cf. bula Scire debes (ibidem, nota 270, pp. 151-152).

( ${ }^{104}$ ) Cf. bula Cum causam (ibidem, nota 271, p. 153). 
siásticos durante quase vinte anos $\left({ }^{165}\right)$. A presença do delegado pontifício em Portugal e em toda a Península significa a importância que Gregório IX dava às questões eclesiásticas, pois a sua intervenção fez-se sentir grandemente tanto nos reinos vizinhos, precisamente nas relações entre a realeza e a Igreja, como entre nós $\left({ }^{168}\right)$, merecendo destacados louvores de Gregório IX pelo modo como exerceu o seu múnus $\left({ }^{167}\right)$. Em 6 de Fevereiro de 1229 já tinha saído de Portugal, onde exercera uma acção disciplinar e reformadora, trabalhando para que se cumprissem os decretos do IV Concílio de Latrão, preocupando-se com a moralização e instrução do clero, procurando remédio para todas as necessidades de ordem religiosa e social, principalmente na reunião da cúria solene de Coimbra, em 1229, numa tentativa de levar a cabo condignas reformas e o apaziguamento da família portuguesa, reunindo por certo, à volta do rei, os prelados e fidalgos desavindos $\left({ }^{188}\right)$.

Neste contexto, talvez que certas explicações dadas em 1229 , de parte a parte, em presença do cardeal legado, tenham contribuído, para uma temporária solução do presente conflito $\left.{ }^{109}\right)$. Contudo, passados 4 anos, isto é, em $1233\left({ }^{170}\right)$, Martinho Rodrigues encaminhava-se de novo para Roma, a queixar-se ao papa Gregório IX de que D. Sancho II continuava a usurpar os direitos da sua igreja e a violar as imunidades eclesiásticas. Gregório IX expediu então várias bulas, como Si quam horribile, Si quam graviter, Cum causam, Cum dudum, mas a situação não se modificou ( $\left.{ }^{171}\right)$.

Assim, em 18 de Fevereiro de 1234, ainda o bispo do Porto se encontrava fora do reino, por motivo da questão com D. Sancho, e não se sabe se voltou à sua diocese. Sabe-se, contudo, que em Junho de 1234, embora tivesse partido de

(105) Cf. José Mattoso, in Alexandre Herculano, ob. cit., t. II, 1. V., nota crítica 29, p. 547.

(106) Cf. A. D. Sousa Costa, ob. cit., notas 264 e 265, pp. 146-148.

(107) Ibidem, nota 267, p. 148 , onde se transcreve o documento Non esset sobre o apreço do papa pelo trabalho de João Abbeville.

${ }^{(188)}$ Cf. Luís Gonzaga de Azevedo, ob. cit., vol. VI, pp. 24-26; J. Augusto Ferreira, Memorias Archeologico-Historicas da Cidade do Porto, Braga, 1923, pp. 211-212. Alexandre Herculano, ob. cit., t. II, 1. V, pp. 387-388; José Mattoso, mota crítica 29, in Alexandre Herculano, ob. cit., t. II, 1. V, p. 547; A. D. Sousa Costa, ob. cit., pp. 146$-149 ; 157-168$.

$\left.{ }^{189}\right)$ Cf. Luís Gonzaga de Azevedo, ob. cit., p. 27.

(100) Em 22 de Março de 1232 encontrava-se em Portugal (cf. A. D. Sousa Costa documento na nota 317, p. 196). Mas em 1233 apresentava ao papa a lista de queixas (A. D. Sousa Costa, ob. cit., p. 197). ${ }^{\left({ }^{171}\right)}$ Cf. as bulas transcritas em A. D. Sousa Costa, ob. cit., notas 320, 321, 322 e 323, pp. 197-204. 
Roma e se encontrasse perto da fronteira portuguesa, havia já algum tempo, que não conseguia entrar no território português por D. Sancho II se recusar a conceder-lhe segurança. E em 16 de Agosto de 1234 encontravarse na Cidade Rodrigo com 0 procurador do rei, mas não chegaram a acordo pelo que o rei foi excomungado $\left({ }^{172}\right)$. De todas as formas, não teve tempo para conseguir alguma coisa do monarca, pois a sua morte é anterior a 17 de Abril de 1235, porque nesta mesma data, Gregório IX refere-se ao prelado, como já falecido. E em Outubro de 1235, aparece-nos já como novo bispo da diocese do Porto, D. Pedro Salvadores $\left({ }^{1 \mp 3}\right)$.

Um outro conflito surgido entre 1233-1234 no reinado de D. Sancho II, tendo em conta as letras pontifícias de Gregório IX, Ad audientiam nostram, Accedens ad sedem apostolicam e In causa electionis, foi com o bispo eleito de Lisboa e sucessor de D. Soeiro, D. Estevão Gomes, prolongando-se depois com mestre João Rolis, capelão e médico pontifício, deão e por fim também bispo de Lisboa $\left({ }^{174}\right)$.

Segundo as referidas bulas, estando vaga a Sé de Lisboa, foi postulado, pelo cabido, para esta mesma Sé, mestre Vicente, já eleito bispo da Guarda. Entretanto, o cabido, sem esperar resposta do papa, com intervenção abusiva do poder secular e não consultados alguns cónegos elegeu mestre Paio que morreu dias depois. Passados mais de oito meses elegeu-se João Falberto, tesoureiro da Guarda. Posteriormente e sob o influxo do poder temporal os cónegos transmitiram ao metropolita de Compostela o direito de eleger pessoa idónea

(122) Cf. documento transcrito na nota 328, ibidem, pp. 205-206. A. D. Sousa Costa admite que Martinho Rodrigues, talvez em Abril de 1234, se dispusesse a regressar a Portugal, dadas as faculdades que Gregório IX lhe concedeu para celebrar ou ouvir missa na sua capela e igrejas a portas fechadas (ob. cit., p. 206). Prova com bastante documentação publicada a pp. 206-210, as últimas tentativas para conseguir a sua entrada em Portugal, e refere-se ao acordo com o próprio rei e à sua morte.

( $\left.{ }^{173}\right)$ Cf. A. D. Sousa Costa, ob. cit., pp. 210-211 e nota 334.

(174) Todo o litígio vem descrito pormenorizadamente nas seguintes bulas de Gregório IX: Ad audientiam nostram, de 25 de Outubro de 1234, endereçada ao abade de Palacios da diocese de Palença, ao mestre escola e a mestre Fernaindo, cónego da mesma diocese, transcrita na íntegra por A. D. Sousa Costa, ob. cit., nota 342, pp. 215-216; Accedens ad sedem apostolicam, dirigida ao próprio D. Estevão Gomes, em 28 de Abril de 1236, ibidem, nota 345, pp. 220-222 e In causa electionis, enviada ao cabido de Lisboa, em 29 de Julho de 1237. ibidem, nota 348, pp. 229-234. 
apesar da eleição anterior não ter sido anulada nem o eleito ter renunciado. Porém, os emissários, ultrapassando o rei e os cónegos teriam dado o encargo ao arcebispo metropolita que, não sem escândalo, para muitos, nomeou o mestre-escola de Lisboa, D. Estevão, acusado de muitos e graves crimes e de certas irregularidades. Perante tal situação, Gregório IX pediu aos destinatários da bula Ad audientiam nostram que se informassem sobre a questão e enviassem para a Cúria Romana todo o processo, determinando o prazo de tempo em que D. Estêvão, por si mesmo, e o cabido pelos seus procuradores, se deviam apresentar na Cúria, para receberem ordens do papa $\left({ }^{1: 5}\right)$.

No entanto, Gregório IX, já tinha escrito em 20 de Outubro de 1234, ao arcebispo de Compostela, proibindo-o de ordenar ou sagrar D. Estevão, visto desejar certificar-se, primeiramente, dos crimes e das irregularidades atribuídas ao eleito e confirmado pelo referido arcebispo ${ }^{(1 i 6)}$. E pela bula Cum olim super, de 17 de Março de 1235, dirigida ao abade de Palacios, mestre escola e mestre Fernando da diocese de Palença, toma providências para fazer face às despesas do processo $\left({ }^{177}\right)$.

Contudo, o processo arrastava-se, pois em 28 de Abril de 1236, pela bula Accedens ad sedem apostolicam, conhecem-se ainda mais pormenores de toda a questão, assim como as posições e as respectivas razões dos contendores aparecendo de toda a exposição que o principal acusador de D. Estevão Gomes era o deão de Lisboa, mestre João Rolis ${ }^{178}$ ). Este defendia, além de outros pontos de vista, que tendo o cabido postulado para bispo da diocese de Lisboa, Mestre Vicente, então bispo eleito da Guarda, e não tendo esperado a resposta do papa quanto à postulação, fora privado ipso iure do direito de eleição, pelo que esse direito passara para o papa, não podendo o cabido transferi-lo para o arcebispo de Compostela e portanto que todas as eleições feitas deveriam ser anuladas. Da mesma bula consta ainda que tendo D. Estevão sido eleito e confirmado pelo metropolita de Compostela, tomado posse dos bens episcopais e recebido obediência dos súbditos, foi ter com el-rei de Portugal para lhe mostrar as letras do arce-

(175) Cf. as bulas Ad audientiam nostram, Accedens ad sedem apostolicam, In causa electionis, in A. D. Sousa Costa, ob. cit., pp. 215$-216 ; 220-222 ; 229-234$.

${ }^{(170)}$ Infere-se da bula Cum super eo, transcrita, ibidem, na nota 343 , p. 216, enviada ao próprio arcebispo de Compostela.

(iir) Bula Cum olim super, ibidem, nota 344 , p. 217.

( $\left.{ }^{178}\right)$ Bula Accedens ad sedem apostolicam, ibidem, pp. 220-222. 
bispo. Contudo, D. Sancho II, não só lhe impediu que regressasse à Igreja de Lisboa, detendo-o, assim como toda a sua comitiva, com violência, na Igreja de S. Pedro do Sul, mas também o despojou dos bens episcopais e de outros bens eclesiásticos e civis $\left(^{170}\right)$. Por isso D. Estevão replicava ao seu asusador que por direito lhe competia a retribuição total dos bens porque nas questões de violência e posse ou de violenta expulsão, devia tratar-se primeiramente da violência e da espoliação e depois da propriedade ou da instituição canónica. Mas como as alegações de parte a parte continuassem, e atendendo que D. Estevão, já sagrado, estava no exercício de todos os direitos episcopais e de alguns temporais da Igreja de Lisboa, e fora espoliado de certos bens seculares pelos oficiais do rei, o papa determinou que os bens sequestrados pelo monarca ou seus oficiais e outros passados à Igreja de Roma pela acção dos comissários pontifícios, lhe fossem restituídos e o deão e seus partidários pudessem continuar a causa na Cúria Romana, ordenando, além disso, se procedesse a um inquérito $\left.{ }^{180}\right)$. E enviando ao arcebispo de Braga a bula Cum olim accedens, ordenava-lhe que urgisse pela plena restituição a D. Estevão dos bens subtraídos pelo rei ou os seus oficiais e outros passados à Santa Sé pela acção do abade de Palácios da diozese de Palença e seus colegas, podendo, para tanto recorrer à censura de excomunhão, inclusive contra o rei $\left({ }^{181}\right)$. Preocupando-se ainda com o caso, Gregório IX mandou fazer dois inventários dos bens episcopais imóveis e móveis, em 6 de Maio de 1236, como consta da bula Dilecto filio, devendo um deles ser enviado ao papa e outro ao arcebispo a quem era dirigida a bula no desejo de evitar prejuízos à Igreja de Lisboa, nos seus bens, com a primeira provisão em favor de D. Estêvão $\left({ }^{182}\right)$.

Mas toda a questão volta a ser tratada ainda na bula In causa electionis, dirigida ao cabido, em 29 de Julho de 1237, onde novamente transparecem as alegações de ambas as partes, oferecendo-nos mais uma vez a repetição dos factos, embora com mais pormenores e diversos complementos às descrições feitas nas bulas anteriores, sinal de que o processo se arrastava em Roma, terminando o documento por referir que expostas as razões de ambas as partes e considerando que na altura de proferir a sentença, D. Estevão renunciava

(170) Ibidem, pp. 221-222.

( $\left.{ }^{180}\right)$ Ibidem, pp. 221-222.

(181) Bula Cum olim, accedens, de 28 de Abril de 1236, ibidem, transcrita na nota 346 , pp. 222-223.

${ }^{\left({ }^{82}\right)}$ Bula Dilecto filio, transcrita ibidem, na nota 347, pp. 223-224. 
espontaneamente a todo o direito que porventura lhe cabia, chamou a si a provisão da Igreja de Lisboa, principalmente por ter notado culpas no proceder do cabido $\left({ }^{183}\right)$.

Entretanto, como a diocese de Lisboa carecesse de prelado, para a governar, Gregório IX, já em 1239 tinha tomado providências, delegando no arcebispo de Toledo e no bispo de Placença, para procederem à designação do bispo para a Sé lisbonense, tendo a escolha destes prelados recaído precisamente na pessoa do capelão e médico pontifício, mestre João Rolis ${ }^{184}$ ).

Os primeiros documentos pontifícios relativos às desavenças e perseguições a mestre João Raolis ou Rolis $\left({ }^{185}\right)$, que, como já referimos anteriormente foi capelão e médico pontifício, deão e bispo de Lisboa, datam bastante antes da sua elevação ao episcopado, talvez dos fins de 1233, pois até a esta data a amizade com o rei era boa, tendo até prestado certos serviços a D. Sancho II $\left({ }^{186}\right)$.

Já em 12 de Outubro de 1233, Gregório IX, ordenava ao

(18) Bula In causa electionis, transcrita in nota 348 , pp. 229-234. Contudo, também em 29 de Julho de 1237 comunica, tanto a renúncia de D. Estevão como a decisão de chamar a si a nomeação do novo bispo de Lisboa, através de bula Causa que uertebatur, aos priores de Santa Maria e P. Nunes de Santiago de Alenquer e a P. Peres, cónego de S. Vicente de Fora, nomeando-os procuradores da diocese no temporal (ibidem, in nota 349, pp. 234-235).

Passado um ano, mais concretamente em 9 de Junho de 1238 manda ao bispo de Osma, chanceler do rei de Castela e de Leão que declare nulos todos os estatutos, sentenças, aluguer de bens da Igreja de Lisboa e a colação de benefícios e dignidades da autoria de D. Estevão Gomes ou seus delegados (cf. bula Cursu prepropero, ibidem, in nota 350, pp. 235-236).

(184) Ibidem, nota 351, pp. 236-237.

(185) Mestre Raolis ou Rolis, na opinião de A. D. Sousa Costa, ob. cit., pp. 251-252, talvez provenha dos cruzados francos, que tomaram parte Ina conquista de Lisboa, como consta de um documento sobre a doação de uma ermida construída pelo sacerdote Raol que pertencia à armada dos Francos (Cf. doc. transcrito na nota 374a, p. 252).

$\left.{ }^{189}\right)$ Sobre as boas relações de mestre João Rolis com D. Afonso II e D. Sancho II ver A. D. Sousa Costa, ob. cit., p. 251 e os documentos transcritos na nota 153 , pp. 73-74 e ainda nas notas 379-381 e 385, pp. 254-260.

Quanto às razões das perseguições a mestre João Rolis e familiares, as bulas pontifícias apontam, com certa insistência, para uma questão de intrigas, invejas e perversidade dos detractores. $t$ o que se deduz, por exemplo, das três bulas com o mesmo título Acuentes sieut serpentes, transcritas nas notas 379,380 e 381, pp. 254-257, duas 
bispo de Palença e arcediago de Carrión e Cerreto que não permitissem que alguém molestasse mestre João, nos seus bens e rendimentos $\left({ }^{187}\right)$.

E em 21 de Dezembro de 1233 escrevia a D. Sancho II a bula Acuentes sicut serpentes, igual em teor e conteúdo à que escrevera também ao bispo de Palença em 23 de Dezembro de 1233. Nestas letras pontifícias Gregório IX queixava-se que D. Sancho II, levado por intrigas e sem atender aos muitos serviços e méritos de mestre João, que o fizeram estimado do monarca, o despojara das igrejas de Santa Maria da Lourinhã e de S. Pedro de Torres Vedras, ocupando-lhes os seus bens e expulsando delas os procuradores do seu capelão, cujos irmãos, consanguíneos e amigos não se atreviam, com medo, a residir nas próprias casas ou aparecer na presença do rei. Por isso pedia ao mesmo prelado que providenciasse às despesas do deão ou dos seus procuradores com os proventos das igrejas vacantes do episcopado de Lisboa $\left({ }^{188}\right)$. E na mesma data comunicava ao mesmo bispo de Palença que também escrevera ao rei para este restituir ao deão e clérigos, no prazo de trinta dias, as igrejas e bens e dar plena liberdade e proteç̧ão aos irmãos e consanguíneos de mestre João, pedindo-lhe, além disso, que apresentasse e expusesse ao rei por monges, cónegos regulares ou clérigos seculares, as letras apostólicas para o monarca cumprir o mandato pontifício e caso recusasse seguir as admoestações do papa, lhe exigisse a restituição dos bens e das igrejas por meio de penas eclesiásticas e o informasse não só sobre os instigadores do monarca, mas também lhe participasse os resultados $\left({ }^{189}\right)$.

dirigidas em 23 de Dezembro de 1233 ao bispo de Palença e outra dirigida ao próprio rei em 21 de Dezembro de 1233.

Relativamente à sua permanência em Portugal, e em Roma como médico e capelão pontifício, Gregório IX, em 27 de Novembro de 1240, afirma haver mais de vinte anos que mestre João dava provas de vida íntegra, com residência tna Cúria de Honório III e na sua própria Cúria (ibidem, nota 358 , onde vem transcrita a bula Dudum ecclesia, com essa referência, pp. 240-242). Por isso mesmo, tinha procuradores em Portugal nomeadamente o seu irmão Simeão Rolis (cf. bula Venerabilis frater, de 18 de Dezembro de 1225, ibidem, nota 163 , pp. 80-84 e p. 251.

${ }^{(187)}$ Cf. bula In tantum, quod, transcrita ibidem, nota 378, pp. 253-254.

$\left.{ }^{188}\right)$ Cf. bula Acuentes, sicut serpentes, transcrita, ibidem, nota 379 , pp. 254-255 e ainda a nota 381, pp. 256-257.

${ }^{\left({ }^{180}\right)}$ Cf. bula Acuentes sicut serpentes, ibidem, nota 380 , pp. 255-256. Embora intitulada do mesmo modo e com a mesma data, esta bula é mais longa que a anterior e mais pormenorizada. Ver a bula dirigida ao rei na nota 381 , pp. 256-257. 
Posteriormente seguem-se várias bulas pelas quais Gregório IX toma diversas providências sobre os procuradores, benefícios e bens do seu capelão $\left({ }^{190}\right)$ até que em 6 de Maio de 1238 se dirige ao arcebispo de Toledo pela bula Tirannidem quam, referindo-se à tirania do rei de Portugal, pois segundo o papa já tinha espoliado, por duas vezes, Mestre João, apesar da estima de que gozava na Cúria Romana e dos favores que prestara ao monarca atrevendo-se a despojá-lo dos seus bens, pela terceira vez, embora constasse, a toda a evidência, que a D. Estevão Gomes não pertencia direito algum sobre o episcopado de Lisboa, servindo-se então de D. Fernando, Infante de Serpa e de outros, que lhe destruiram as casas do deado, queimaram todos os utensílios, despojaram os seus consanguíneos dos próprios bens, obrigando-os a viver miseravelmente no exílio. E quando estes se refugiaram, com os bens do deão, numa igreja fechada, o Infante de Serpa valera-se dos sarracenos que, violentamente, assaltaram a igreja e profanaram, calcando aos pés, a Eucaristia, o crucifixo e o crisma e roubaram os bens que possuiam. Por este motivo teve de providenciar às carências dos familiares do seu capelão e médico, com uma condigna provisão, recorrendo, para tanto, ao auxílio das igrejas catedrais e mosteiros dos reinos de Castela e Leão ${ }^{\left({ }^{191}\right)}$.

E procurando uma maior justiça para o seu protegido, dirigiu-se novamente a D. Sancho pela bula Si tua sublimitas, em 4 de Junho de 1238, transcrevendo neste documento toda a bula anterior Tirannidem quam, repreendendo-o e ameaçan. do-o severamente com o recurso ao poder secular, caso não reparasse os males, pois não cumpria a sua missão de proteger e defender a igreja $\left({ }^{102}\right)$. E em 20 de Dezembro de 1239, pelas bulas Multe compassionis affectus e In eodem modo, dirigidas respectivamente ao cabido e ao povo de Lisboa, esclarecia que o arcebispo de Toledo e de Placença tinham escolhido para bispo de Lisboa o seu capelão e médico mes-

${ }^{(100)}$ Assim, em 20 de Julho de 1234, pela bula Negotio dilecti manda ao mesmo bispo de Palença que constitua procuradores na causa contra os invasores ou detentores dos bens (cf., ibidem, nota 382 , p. 257). Em 24 de Dezembro de 1234, pela bula Beneficia Magistri, comunica ao cabido de Lisboa ter chamado a si todos os benefícios do seu capelão e médico (Cf. ibidem, p. 257 e nota 383, pp. 257-258). A 2 de Janeiro de 1235, pela bula Etsi te nuper dirige-se ao próprio mestre João, declarando tê-lo despojado dos seus bens, por motivo de cautela e fez-lhe a restituição dos mesmos (cf. nota 384, p. 258).

${ }^{(191)}$ Cf. bula Tirannidem quam, dirigida ao bispo de Palença, transcrita, ibidem, na nota 385, pp. 259-260.

${ }^{(102)}$ Cf. bula Si tua sublimitas, transcrita integralmente, ibidem, na nota 386, pp. 260-261. 
tre João Rolis, que conhecia pessoalmente como um homem culto, previdente, discreto e de vida íntegra, tendo-o por isso mesmo ordenado sacerdote e sagrado bispo, constituindo tal escolha uma graça para a diocese lisbonense, pois se privara, para tanto, dos serviços do seu capelão, dando-o àquela diocese, devendo asim o cabido e o povo recebê-lo com obediência e reverência, e tributar-lhe as devidas honras como pai e pastor de todos $\left({ }^{193}\right)$.

Contudo, Gregório IX não se dirigiu apenas ao povo de Lisboa, mas teve também o cuidado de enviar na mesma data ao próprio rei D. Sancho o conteúdo das duas bulas, exortando-o a proteger e honrar o novo bispo e toda a Igreja de Lisboa $\left({ }^{194}\right)$.

No entanto, ainda na mesma data de 20 de Dezembro de 1239, pela bula Veniens ad apostolicam sedem, dirigida ao bispo de Osma, descreve as tropelias de D. Fernando Serpa, não só contra o bispo de Lisboa, mas também contra mestre Vicente, então bispo da Guarda, com larga referência à penitência imposta ao infante que acabara finalmente por implorar o perdão ao próprio Papa ${ }^{\left({ }^{105}\right)}$. E continuando na sua descrição relata ainda não só o pernicioso sequestro de bens e as destruições que o próprio D. Fernando Serpa levara a cabo, mas também alude à cumplicidade de certos clérigos, tanto de Lisboa como de Santarém e de Braga, que não só colaboraram com o infante, mas o instigaram às violências, recebendo até dinheiro de alguns deles, a fim de perseguir os familiares de João Rolis e destruir os seus bens $\left({ }^{198}\right)$. Finaliza o longo documento com menção à restituição dos bens sequestrados, à necessidade de uma condigna satisfação aos ofendidos e às condições fundamentais a que deveria obedecer a dura penitência que o infante era obrigado a cumprir, assim

$\left({ }^{103}\right) \mathrm{Cf}$. as bulas Multe compassionis affectus e In eodem modo, ibidem, notas 351 e 352, pp. 236-237.

(104) Cf. o documento pontifício dirigido a D. Sancho II, ibidem, nota 353, p. 237.

$\left({ }^{105}\right)$ Cf. bula Veniens ad apostlicam sedem, transcrita integralmente, ibidem, na nota 389, pp. 264-266.

(108) Ibidem, p. 265. Os vários cúmplices designados na bula são: Gil, arcediago de Santarém que dera trezentos aureos; Nuno Gomes, mestre-escola de Lisboa e vigário temporal que entregara os documentos sobre dívidas do bispado e lhe indicara por escrito onde se encontravam os bens e proventos episcopais; Mestre João Fernandes, cónego de Braga; o clérigo Miguel Ovequiz, João Gomes e F. Gomes, irmãos do mestre-escola; e os sobrinhos do arcediago Gil, L. Gonçalves e R. Gonçalves que contribuiram também para a perseguição. 
como a sua absolvição de todas as censuras em que incorrera $\left({ }^{197}\right)$.

D. Sancho II aparece nos documentos de Gregório IX como conivente nesta perseguição liderada pelo Infante de Serpa não só pela negligência em intervir a favor dos perseguidos, mas fundamentalmente pela má vontade contra a eleição do capelão pontifício para bispo da Igreja de Lisboa ${ }^{(108)}$.

Seguiram-se várias bulas sobre a concessão e execução de faculdades ao novo prelado, como a de conservar os benefícios da cidade e diocese, de proceder contra os administradores pelo uso ilícito que fizeram no interregno dos bens da Igreja de Lisboa e ainda sobre certas ordens dadas aos procuradores da mesma Igreja relativamente à entrega dos bens $\left({ }^{100}\right)$.

${ }^{(107)}$ Quanto ao desfecho de toda esta questão e à penitência imposta ao Infante de Serpa, ver A. D. Sousa Costa, ob. cit., pp. 264-277 , onde além de importante documentação descreve pormenorizadam€nte os próprios factos. Pela bula Cum viris, de 29 de Abril de 1237, dirigida ao arcebispo de Toleda e bispo de Leão, sabe-se que D. Vicente se lamentava de graves perseguiçōes infligidas pelo irmão de D. Sancho II, D. Fernando, às igrejas e eclesiásticos de Portugal, designadamente de invadir e dissipar os bens que àquele prelado e familiares possuiam tanto em Lisboa como na Guarda. Em Santarém, estando presente $\mathrm{U}$. Vicente, matara alguns dos seus clérigos de ordens sacras e escritores do rei não desistindo, segundo a mesma bula, de causar danos sobre danos. Por tal motivo o papa incumbia os delegados apostólicos de se informarem da verdade dando-lhes poderes para fulminarem de excomunhão tanto o Infante como os seus cúmplices. Mas finalmente D. Fernando acabara por implorar perdão ao papa e por ser perdoado por D. Vicente. D. Sancho aparece nos documentos pontifícios como conivente com base ao menos na negligência em intervir a favor dos perseguidos. Todavia, rigorosamente, talvez não se possa dizer instigador no que se refere às queixas de D. Vicente, pois entre os clérigos assassinados havia escritores do rei rei (cfr. A. D. Sousa Costa, notas 385 e 387, pp. 259-266).

${ }^{\left({ }^{108}\right)}$ Sobre a questão cf. principalmente a bula Tirannidem quam, nota 385 , transcrita, ibidem, pp. 259-260. Sobre as relações do Infante de Serpa com D. Sancho II, seu irmão, e como possível candidato do papa à coroa de Portugal, ver as importantes notas críticas 70 e 89 de José Mattoso, in Alexandre Herculano, ob. cit., t. II, l. V, pp. 552 e 555 .

${ }^{(193)}$ Cf. a bula Cum sicut te, de 21 de Dezembro de 1239, dirigida ao novo bispo de Lisboa, transcrita in A. D. Sousa Costa, ob. cit., na nota 354, pp. 237-238 e ainda a mesma bula enviada ao bispo e chantre de Salamanca, transcrita na nota 355, p. 238; Cum sicut accepimus, também de 21 de Dezembro de 1239, endereçada ao bispo de Lisboa, transcrita na nota 356, p. 238; Olim Vlixbonen ecclesia, da mesma data, enviada ao arcediago de Vermoim de Braga, e ao prior de Santiago de Alenquer, transcrita na nota 357, p. 239. 
Mas, apesar de todos estes esforços do papa, a aceitação de João Rolis, segundo a bula Dudum ecclesia, de 27 de Novembro de 1240 , não foi pacífica, pois nem todos os cónegos receberam com agrado a sua nomeação para bispo de Lisboa e o próprio rei, D. Sancho II, mostrou o seu grande descontentamento, acabando até por enviar à Cúria Romana o seu chanceler D. Durando Froiaz que juntamente com outros manifestou abertamente a sua oposição $\left({ }^{200}\right)$.

${ }^{(200)}$ Segundo a bula Dudum ecclesia, dirigida ao próprio bispo D. João Rolis, o papa relata que compareceram na Cúria pontifícia a opor-se à nomeação, Mestre João conhecido como doutor em Leis, M. Nunes, dito cónego de Lisboa, em seu nome e de Gil, arcediago de Santarém, Mestre Domingos e João Domingues, cónegos de Lisboa, no próprio nome e de Miguel e Gil Ovequiz, reitores das igrejas de Santa Maria de Sintra e de Santiago de Torres Vedras e, em inome de el-rei, o chanceler D. Durando Froiaz, mas que pela exposição verificou que pretendiam unicamente difamar $o$ bispo movidos de inveja e ódio pelo que determinara que não fossem dados ouvidos a tais detractores (Cf. bula Dudum ecclesia, transcrita na nota 358 , pp. pp. 240-242).

Quanto à motivação destas perseguições depreende-se, facilmente, dos documentos pontifícios citados, que toda a má vchtade do monarca contra o capelão pontifício, teve origem nas questōes de eleição do bispo de Lisboa, iniciadas em 1233, intervindo D. Sancho, pessoalmente, como vimos, após a morte de D. Soeiro Viegas, pois o cabido foi constrangido pelo poder secular a proceder à eleição de mestre Paio e posteriormente de João Falberto, seguindo-se D. Estevão Gomes que, segundo a sua versão, fora impedido pelo rei de entrar na sua diocese e detido violentamente na Igreja de $\mathrm{S}$. Pedro do Sul (A. D. Sousa Costa, notas 342-345). Finalmente a questão subiu à Cúria Romana pelos procuradores de mestre João que se tornou o principal adversário de D. Estevão que fora eleito e sagrado pelo metropolita de Compostela (ibidem, notas 342-347). Ora foi por este tempo ou logo a seguir, dando crédito aos documentos papais, que nos aparecem as primeiras notícias da acção de D. Sancho II, contra o deão e capelão pontifício, nas pessoas dos seus procuradores, familiares e bens (ibidem, notas 378-379). E a questão ainda se torna mais clarividente, seguindo de perto as letras apostólicas, quando, mais tarde, verificamos que alguns cónegos protegidos de D. Estevão Gomes (pois lhes concedera certos benefícios), e de pessoas de família, juntamente com a chanceler do rei, D. Durando Froiaz, se opöem à designação de $\mathrm{D}$. João Rolis para bispo de Lisboa e que segundo as bulas já referidas, perseguem, violentamente, durante vários anos (ibidem, notas 358 e 389 ).

De facto, João Rolis insistia como principal argumento, no devër do cabido esperar resposta da Santa Sé e na legitimidade da postulação de D. Vicente (ibidem, notas 342,345 e 343 ). Concluindo: no princípio D. Sancho não estava de acordo com a eleição de D. Estêvão Gomes, mas depois aparece a perseguir o principal opositor do bispo eleito, mestre João Rolis, em favor de D. Estêvão, talvez por este contemporizar com os seus desejos; contudo, no princípio, devia ter estado com o capelão pontifício, pois em 1233 ainda gozava das suas graças (ibidem, nota 385 ). 
Quanto ao desfecho de toda a contenda, refere D. Rodrigo da Cunha, que em 18 de Outubro de 1240, D. João Rolis autorizava de Roma o seu sucessor no deado, a terminar as questões com D. Sancho II, estabelecendo-se, de facto, uma concórdia em 15 de Julho de 1241, com o bispo de Lisboa, que então residia na Cúria pontifícia $\left({ }^{201}\right)$, sabendo-se por outro lado que em Outubro de 1241 já se encontrava vaga a Sé de Lisboa $\left({ }^{202}\right)$.

Depois da morte de D. Martinho Rodrigues foi nomeado para a Sé Portucalense D. Pedro Salvadores que foi sagrado bispo em Roma pelo próprio papa Gregório IX, aparecendo já em Setembro e Outubro de 1235, como bispo do Porto $\left({ }^{203}\right)$. Como antecedentes do conflito com D. Sancho II regista-se que em $1237 \mathrm{D}$. Pedro se dirigiu por carta ao capítulo dos Dominicanos, reunidos em Burgos descrevendo-lhes a situação de Portugal em termos dramáticos, pedindo-lhes que enviassem alguns membros para a sua diocese, como remédio para as desordens e males existentes $\left({ }^{204}\right)$.

Em 24 de Janeiro de 1238, talvez a pedido de D. Pedro Salvadores, Gregório IX proibe os prelados e religiosos portu-

(201) Cf. D. Rodrigo da Cunha, Historia ecclesiastica da Igreja de Lisboa, Parte II, cap. XXXXI, n. ${ }^{\circ}$, pp. 153-154.

$\left.{ }^{(02}\right)$ Cf. D. Rodrigo da Cunha, ob. cit., p. 155, onde este autor afirma que D. João faleceu no ano de 1241, entre 15 de Julho e 20 de Outubro. Ver também A. D. Sousa Costa, ob. cit., p. 243.

${ }^{(203)}$ Ver a documentação sobre a nomeação na data referida em A. D. Sousa Costa, ob. cit., notas 334 e 335, pp 210-212. Cf. J. Augusto Ferreira, Memorias Archeologico-Historicas da cidade do Porto, Braga, 1923, p. 217; Luís G. Azevedo, ob. cit., vol. VI, p. 64. A data da elevação ao episcopado de D. Pedro Salvadores apresentada por estes dois autores é ultrapassada pelos documentos de A. D. Sousa Costa. Vide também Monarquia Lusitana, Parte IV, 1. XIII, cap. XIIII, pp. $137 \mathrm{v} .-138 \mathrm{v}$.

$\left({ }^{204}\right)$ Cf. a carta publicada por A. D. Sousa Costa, ob. cit., nota 516, pp. 405-406. Na opinião de J. A. Ferreira tais queixas recaíram virtualmente sobre a tolerância ou conivência do rei D. Sancho II (ob. cit., p. 217). Luís G. Azevedo, ob. cit., vol. VI, pp. 65-66 transcreve parte da carta e argumenta que os burgueses tinham tendência para se apoiarem na coroa contra o prelado. Então o bispo para tirar aos vassalos o apoio do rei buscou o auxílio dos Dominicanos. Nessa carta, que é uma crítica velada a D. Sancho II, refere-se D. Pedro Salvadores aos infinitos salteadores que transformavam os mosteiros e igrejas em covas de latrocínios e em castelos da soldadesca, aos saques das fazendas dos clérigos, lavradores e religiosos, às mortes à espada dos caseiros e clérigos diante dos altares ou em fogueiras, etc., dando uma imagem da anarquia no país. 
gueses de absolverem D. Sancho II através da bula Si quam horribile $\left({ }^{205}\right)$.

Seguiram-se diversas bulas e de todas se conclui que as acusações contra o rei eram semelhantes às dos litígios já havidos com os outros prelados, resumindo-se no desrespeito pelas imunidades eclesiásticas $\left({ }^{206}\right)$.

Em 30 de Março de 1238 enviou mais duas bulas, constando de uma delas a exortação ao rei para satisfazer as décimas reais; a não recepção dos comissários e o levantamento de excepções contra o rescrito por parte do rei; a publicação solene e pública do rescrito nas igrejas; a audição de testemunhas idóneas e a elaboração de um documento público com as respectivas declarações; a citação do monarca a assistir ao exame das testemunhas e a redacção de um documento sobre a citação $\left({ }^{207}\right)$.

Seguiram-se outras bulas $\left({ }^{208}\right)$ no mesmo dia e ano sobre as mesmas questões tendo o rei sido excomungado como se refere nas letras apostólicas Significauit nobis, após repetidas admoestações $\left({ }^{209}\right)$.

Também na mesma data de 30 de Março de 1238 Gregório IX informa que D. Pedro Salvadores excomungara todos os que ousaram aceitar igrejas e benefícios eclesiásticos de el-rei, pedindo ao bispo de Orense, a quem se dirigiu, que fizesse observar a excomunhão fulminada pelo prelado portuense $\left({ }^{210}\right)$.

Pela bula Cum ferro abscidenda o papa pede ao mesmo bispo de Orense que impeça os Dominicanos e Franciscanos e outros religiosos isentos de não observarem o interdito nos lugares aonde o rei chegasse $\left({ }^{211}\right)$.

Perante este cerco de admoestações e censuras, D. Sancho submeteu-se à Igreja. Assim, em Maio de 1238 estabeleceu-se a composição entre D. Sancho II e o bispo e o cabido do

$\left.{ }^{(205}\right)$ A bula Si quam horribile vem transcrita em A. D. Sousa Costa, ob. cit., nota 515, p. 405.

$\left({ }^{206}\right)$ As bulas Exposita nobis, Ex parte venerabilis, Significauit nobis, Cum ferro abscidenda, in A. D. Sousa Costa, ob. cit., pp. 408-411.

$\left({ }^{207}\right)$ Cf. bula Exposita nobis, de 30 de Março de 1238, ao deão, chantre e tesoureiro de Zamora, ibidem, nota 518, p. 408.

$\left({ }^{208}\right)$ Cf. bula Ex parte venerabilis de 30 de Março de 1238, enviada ao deão, chantre e tesoureiro de Zamora, ibidem, nota 519, pp. $408-409$; pp. $381-384$ e nota 488 , p. 384.

$\left({ }^{208}\right)$ Cf. bula Significauit nobis, dirigida ao bispo de Orense, em 30 de Março de 1238, ibidem, nota 521, pp. 409-410.

$\left({ }^{210}\right)$ Cf. bula Ex parte venerabilis, ao bispo de Orense, ibidem, in nota 522 , p. 410.

$\left.{ }^{211}\right)$ Cf. bula Cum ferro abscidenda, ibidem, nota 523, p. 411. 
Porto a enviar ao papa Gregório IX para confirmação $\left({ }^{212}\right)$. Em 25 de Julho do mesmo ano D. Sancho II nomeia o chanceler D. Durando Froiaz seu procurador para receber a absolvição do bispo de Salamanca e deão de Zamora, levando uma declaração de se ter obrigado a dar o direito de padroado de todas as igrejas da diocese do Porto, no caso de faltar à composição celebrada com o bispo e cabido portuenses $\left({ }^{213}\right)$.

Em 17 de Agosto, também de 1238, D. Durando Froiaz apresenta ao bispo de Salamanca, em nome de D. Sancho II, o documento com o pedido régio da absolvição, com declarações do bispo do Porto e do monarca e de este ter satisfeito pelos agravos ao prelado e à igreja do Porto $\left({ }^{214}\right)$.

Estavam assim normalizadas as relações entre D. Pedro Salvadores e o rei pela referida composição, renunciando ambas as partes à obrigação do pedido de confirmação ao papa, apesar de o terem redigido, sendo talvez, por isso, que só muito mais tarde, isto é, a 6 de Julho de 1254 e a pedido do bispo D. Julião, Inocêncio IV confirma, excluindo o artigo sobre as causas dos eclesiásticos e leigos aos quais o papa continuava a reclamar para o foro eclesiástico $\left({ }^{215}\right)$.

E provável que a seguir à composição referida, que teve o seu início em Maio de 1238, entre o rei e o bispo do Porto, os ânimos serenassem e D. Sancho tivesse influenciado os cidadãos do Porto para chegarem a um acordo com D. Pedro Salvadores em Setembro de 1240, por meio do prelado eleito de Coimbra, D. Tibúrcio, e Abril Peres. No documento da concórdia faz-se referência a D. Rodrigo Sanches, filho bastardo de D. Sancho I, como sendo um dos causadores de grandes danos e agravos à diocese e ao bispo $\left({ }^{216}\right)$.

Após a concórdia, D. Pedro Salvadores deve ter partido para o concílio, a realizar em $1241\left(^{217}\right)$.

Sabe-se que em Maio de 1241 se encontrava em Génova,

$\left.{ }^{212}\right)$ Cf. A. D. Sousa Costa, ob. cit., pp. 411-418. A composição encontra-se transcrita na nota 524, p. 413. Em complemento destes factos vide A. Cruz, ob. cit., pp. 190-194 e notas críticas 74 e 75 de J. Mattoso in Alexandre Herculano, ob. cit., t. II, pp. 552-553.

${ }^{213}$ ) A. D. Sousa Costa, ob. cit., nota 524, p. 413.

(24) Ibidem, nota 524, pp. 413-418, onde se encontram todos os documentos referentes a esta concórdia entre D. Pedro Salvadores e D. Sancho II.

$\left.{ }^{215}\right)$ Ibidem, pp. $413-418$, nota 525 , pp. $418-419$. Sobre a relação desta composição com a aprovação da concórdia em 2 de Fevereiro de 1245 por Inocêncio IV ver A. D. Sousa Costa, ibidem, pp. 418-421.

(218) Ibidem, nota 530, pp. 421-423.

(217) Ibidem, nota 531 , p. 423. 
não constando que tivessem surgido questões pormenorizadas entre ele e D. Sancho $\left({ }^{218}\right)$.

Os primeiros indícios das desinteligências de D. Silvestre Godinho, Arcebispo de Braga, com D. Sancho II encontram-se nos documentos de Outubro e Novembro de $1234\left({ }^{219}\right)$.

$\left.{ }^{218}\right)$ Ibidem, pp. 423-424. Como no tempo de D. Sancho I e de D. Martinho Rodrigues, os burgueses do Porto, embora provavelmente abandonados pelo rei, não se sujeitaram ao prelado, apesar da concórdia entre D. Sancho II e D. Pedro Salvadores, feita em Maio de 1238, mas persistiram na sua luta contra o bispo durante mais de dois anos (1238-1240).

D. Pedro Salvadores talvez para quebrar a resistência dos seus vassalos descontentes e em certa rebelião, confiou a alguns fidalgos o) governo da cidade que foram severos para com os burgueses. Estes redigiram então uma espécie de carta-manifesto que enviaram aos arcebispos, bispos, prelados das igrejas e mais fiéis onde se queixavam de D. Pedro Salvadores, cujos direitos estavam prontos a reconhecer, segundo o que resolvesse o arcebispo de Braga ou o seu rei, para quem apelavam, mas que o seu bispo rejeitava a apelação do seu metropolita e entregara o governo da cidade a fidalgos que os tratavam com a maior dureza, chegando a enforcar alguns e a vender por dinheiro os seus filhos e mulheres como se fossem mouros. (Cf. Carta-Manifesto in L. G. Azevedo, ob. cit., vol. VI, pp. 188-191).

De facto, a influência pacificadora de D. Silvestre Godinho, arcebispo de Braga. como metropolita, neste litígio, fora repelida por D. Pedro Salvadores.

Contudo o concelho do Porto era apoiado com armas por D. Rodrigo Sanches, filho bastardo de D. Sancho I, lugar tenente de D. Sancho II, em grande parte do território entre Lima e Douro e ainda por Fernando Annes, chantre da Sé de Braga, homem poderoso, que disputava ao bispo portuense o padroado da Igreja do Monte Córdova.

Para Alexandre Herculano (ob. cit., t. II, 1. V, p. 458) D. Rodrigo Sanches fora para a Igreja portuense, mais ou menos brutalmente o mesmo que Fernando Serpa fora para a lisbonense, isto é, o seu flagelo.

E segundo descreve Luís Gonzaga de Azevedo (ob. cit., pp. 7879), D. Rodrigo Sanches obrigou D. Pedro Salvadores a aceitar como árbitros não os propostos pelos burgueses, mas o novo bispo de Coimbra, mestre Tibúrcio, e Abril Peres, senhor de Lumiares os quais em Setembro de 1240 deram a sentença e condenaram os burgueses a pagar dois mil aureos de indemnização ao bispo por perdas e danos, ordenando-lhe que não entregasse o governo da cidade a fidalgos e levantasse todas as excomunhões, e tanto o bispo como D. Rodrigo Sanches e Fernando Annes se perdoassem mutuamente de todo o rancor e sofrimentos causados.

${ }^{(219)}$ Sobre as relações entre D. Sancho II e D. Silvestre Godinho, arcebispo de Braga, ver a importante documentação em A. D. Sousa Costa, ob. cit., pp. 358-388. Este autor prova na primeira parte da sua obra, pp. 15-54, a identificação de Mestre Silvestre, arcediago, deão e por fim arcebispo de Braga com o decretalista Silvestre. Foi 
Em 25 de Outubro de 1234, Gregório IX, por informações de D. Silvestre Godinho, manda reprimir certos abusos dos Templários e outros religiosos $\left({ }^{220}\right)$.

Pela bula de 28 de Novembro de 1234 endereçada a D. Sancho II, o papa recorda-lhe o dever de proteger as igrejas contra as injustiças dos poderosos, informando-o de que o arcebispo de Braga necessitava dos seus préstimos contra a violência de certos nobres que protegiam determinado administrador que se recusava a prestar contas à mesa episcopal $\left({ }^{221}\right)$.

Em 1236 Gregório IX dirige-se ao bispo, deão e tesoureiro de Lamego, referindo as queixas do cabido de Braga contra o prior e cónegos regrantes de Santo Agostinho de Grijó por darem sepultura em sagrado a excomungados $\left({ }^{222}\right)$.

Em 24 de Janeiro de 1238 o papa proibia o arcebispo e demais prelados portugueses de absolverem D. Sancho II das penas de excomunhão e interdito, sem licença da Santa Sé devido à perseguição do monarca ao bispo do Porto $\left({ }^{223}\right)$.

Mas de todos os documentos pontifícios o mais importante é a bula Si quam horribile de 15 de Abril de 1238, enviada ao próprio rei D. Sancho II, onde se relatam as principais queixas contra este monarca e que provavelmente se deve a informações de D. Silvestre Godinho $\left({ }^{224}\right)$.

Nesta bula faz-se alusão à constituição de D. Afonso Henriques sobre a captura de mulheres nas casas dos clérigos, aos obstáculos movidos ao arcebispo e vigários no exercício do seu poder, às multas pecuniárias impostas aos eclesiásticos pela recusa a tomarem parte no exército, encargos das angárias e perangárias, conservação e sustento dos homens e cavalos do rei, estatutos a impedirem doações, legados e compras, obrigação de responderem perante os tribunais civis, exigência de procurações e impostos, comunicação com os

nomeado arcebispo por Gregório IX a 4 de Julho de 1229 e sagrado a 4 de Agosto do mesmo ano. Ver elementos sobre a sua eleição e outros factos em J. Augusto Ferreira, Fastos Episcopaes da Igreja Primacial de Braga, Ed. Mitra Bracarense, t. II, 1931, pp. 7-23; e ainda em A. D. Sousa Costa, ob. cit., notas 112 e 113, pp. 51-53 e 359 . Ver também o relato bastante minucioso em Luís G. Azevedo, ob. cit., vol. VI, pp. 71-75; Monarquia Lusitana, Parte IV, l. XIIII, cap. XVII, pp. $141-143$.

$\left({ }^{220}\right)$ Cf. A. D. Sousa Costa, ob. cit., nota 474 , p. 364 , onde vem transcrita a bula $E x$ parte venerabilis sobre a questão.

( $\left.{ }^{221}\right)$ Bula Consueuerunt et debent, nota 475 , p. 365.

${ }^{(222)}$ Bula Ex parte dilectorum, nota 476, p. 366.

(23) Bula Si quam horribile sit, nota 515, p. 405.

(24) Cf. A. D. Sousa Costa, ob. cit., pp. 367-368. A bula Si quam horribile, encontra-se na íntegra na nota 481, pp. 369-372. 
excomungados, ocupação dos bens eclesiásticos, reivindicação do direito de padroado, opressão sobre as igrejas e mosteiros e respectivos colonos com impostos.

Por fim Gregório IX descreve que D. Silvestre admoestou várias vezes o monarca, mas sem qualquer êxito, pelo que lançara a sentença de excomunhão contra os barões e todos os que por mandato régio atentavam contra a liberdade eclesiástica. Exorta D. Sancho II a reprimir os barões e a desistir dos agravos, comunicando-lhe que dera ordens aos metropolitas para lançar interdito nos lugares aonde chegasse, caso não se comprometesse a observar todos os artigos elencados na bula e a velar pela plena segurança do arcebispo e dos seus $\left({ }^{225}\right)$.

$\mathrm{Na}$ mesma data endereçou a bula Si illustris Rex Portugalie, no mesmo teor e termos, ao arcebispo de Braga, incumbindo.o de executar o mandato pontifício ${ }^{220}$ ).

Seguem-se mais duas bulas, ambas intituladas $S i$ quam graviter, respectivamente de 20 de Abril e 10 de Maio de 1238 em que Gregório IX refere que o rei privara a Igreja de Braga das décimas reais dando por isso faculdades aos delegados apostólicos de lançarem o interdito nos lugares aonde chegasse $\left({ }^{227}\right)$.

Perante todas estas ameaças D. Sancho II, acabou por se comprometer a observar todos os artigos da referida bula Si quam horribile, de 15 de Abril de 1238 ( ${ }^{228}$ ) por carta patente, datada de Guimarães, aos 25 de Novembro de 1238 € no dia seguinte, procedeu-se a uma composição pela qual o rei dava ao arcebispo e cabido a Igreja de Ponte de Lima e a de Touguinha, e em compensação dos frutos das décimas concedeu os Coutos de Gouvães e de Prado e muitos bens em Adaúfe, terra de Panoias e o metropolita entregava ao mo narca o castelo de Penafiel de Bastuço, renunciava aos direitos de Capelaria e Chancelaria na Cúria Régia, ao privilégio de cunhar moeda, e ainda aos direitos nas igrejas do padroado real do arcebispado $\left({ }^{229}\right)$.

Depois desta concórdia parece não ter havido sinais de

(225) «...eidem Archiepiscopo et suis plenam securitatem impendens: (ibidem, p. 371). $372-375$.

$\left.{ }^{228}\right)$ Bula Si illustris Rex Portugaliae, ibidem, nota 482, pp.

$\left.{ }^{227}\right)$ Bulas Si quam graviter, ibidem, notas 483 e 484, pp. 375-376.

$\left.{ }^{228}\right)$ Os artigos são repetidos na bula já citada $S i$ illustris Rex Portugaliae (nota 482, pp. 372-375).

$\left.{ }^{289}\right)$ A carta patente encontra-se transcrita, ibidem, p. 377 e a composição na nota 486 , pp. 378-380. 
outras discórdias com o arcebispo metropolita de Braga, D. Silvestre Godinho, que morreu em Roma, em 1244 ( $\left.{ }^{230}\right)$.

Os conflitos que abordámos até aqui, referentes não só ao tempo de D. Sancho II, mas também aos governos anteriores, talvez ajudem a compreender melhor a situação do país, principalmente entre 1240 a 1245 , ou mais propriamente a crise de $\left.1245{ }^{(231}\right)$.

E verdade que o reinado de D. Sancho II foi agitado por guerras civis e tumultos em que o poder, já durante a sua menoridade, provavelmente, transitara de mão em mão, com prejuízos incalculáveis para o reino e por conflitos contínuos e sangrentos dos nobres entre si, de assaltos e espoliações, etc. $\left.{ }^{232}\right)$. Mas não pode esquecer-se que grande parte desta situação herdara-a o rei, em quase todos os seus aspectos, aliás como facilmente se infere do que atrás ficou dito, dos reinados dos seus antecessores, onde devem ir buscar-se algumas das suas raízes mais profundas.

No entanto, talvez se possa dizer que tal situação se tenha generalizado e intensificado durante a sua menoridade a que, posteriormente, ainda se vieram juntar outros factores, quer positivos quer negativos, mas não menos importantes e significativos, como o triunfo em certo modo humilhante para a coroa não só do arcebispo de Braga, D. Estevão Soares da Silva, mas também do partido oposicionista à política de D. Afonso II, parecendo constituir tal facto um certo recuo na evolução e esforço bem acentuados, no tempo daquele monarca, em ordem à centralização. Também a expedição contra Elvas (1226), que parece ter fracassado, contribuira, de certo, para uma maior desunião dos fidalgos a D. Sancho II,

(200) Cf., ibidem, nota 50, pp. 15-17 e pp. 379-380.

(21) A crise de 1245 é tratada nesta mesma Revista de uma maneira profunda, actualizada e de impar abertura de perspectivas pelo Doutor José Mattoso, sendo por isso, quase diríamos, inútil, abordar aqui o mesmo tema. Porém, se aludimos novamente a esta questão é unicamente por uma razão de lógica e de sequência dos acontecimentos e conflitos existentes no reinado de D. Sancho II, pelo que remetemos o leitor para a utilidade e a necessidade de ler o importante contributo daquele professor.

(222) Em ordem à descrição tradicional dos acontecimentos, ver Alexandre Herculano, ob. cit., t. II, l. V, pp. 347-559 e L. G. Azevedo, ob. cit., vol. VI, principalmente pp. 9-29; 80-87 e 129-151; Angelo Ribeiro, "A Revolução do Bolonhês», in História de Portugal, vol. II, dir. de Damião Peres, Barcelos, 1929, pp. 225-230 e Fortunato de Almeida, História de Portugal, 1922, t. I, pp. 209-213. 
que se sentira abandonado por prelados e nobres $\left({ }^{233}\right)$. A chegada de João Abbeville a Portugal, em fins de 1227, tendo como causa a situação irregular do país e os problemas de natureza eclesiástica, foi benéfica, a todos os títulos, mas não foi suficiente para erradicar os males existentes $\left({ }^{234}\right)$. 0 reinício da Reconquista entre 1230-1238, com vitórias importantes em todo o Alentejo, chegando até a atingir-se Tavira $\left({ }^{235}\right)$, deram uma maior satisfação e tranquilidade a Roma, dado o empenho e as insistentes diligências da Santa Sé pela guerra Santa, mas não foram determinantes para impedir definitivamente, as ameaças de excomunhão $\mathrm{e}$ interdito das inúmeras bulas que, como vimos, eram o reflexo não só da expressão das queixas e dos agravos principalmente dos bispos do Porto, Braga e Lisboa, mas também das respectivas concordatas $\left({ }^{236}\right)$. Nem do reinado de D. Sancho II estiveram ausentes as desavenças entre os burgueses e os bispos, entre as dioceses da Guarda e Coimbra, e de Viseu e Guarda ( ${ }^{237}$ ), o banditismo,

$\left.{ }^{233}\right)$ Luís Gonzaga de Azevedo, ob. cit., vol. VI, pp. 18-19 e 141-151 defende até a existência de uma guerra civil após o assalto fracassado a Elvas, confirmando que o rei fora abandonado por prelados e fidalgos com o propósito de darem o trono a seu irmão D. Afonso, em quem reconheciam mais aptidão para o governo. Porém, que tal tentativa não prevalecera, porque seu tio, Martim Sanches, entrara em Portugal com socorros militares, mandados pelo rei de Leão para o sustentarem no trono, e que depois de uma curta guerra civil, que flagelou Trás-os-Montes, $D$. Afonso fora vencido e lançado do reino, do qual partira, acompanhado por alguns amigos fiéis (veja-se ainda sobre o fracasso de D. Sancho, salvamento da sua vida por Afonso Mendes Sarracins, data, etc., as notas críticas de José Mattoso, 18, 20, in Alexandre Herculano, ob. cit., t. II, l. V, pp. 545-546; Alexandre Herculano, ibidem, pp. 371-376 e nota XIX, pp. 618-619).

${ }^{\left({ }^{24}\right)}$ Cf. Luís Gonzaga de Azevedo, ob. cit., pp. 24-25; veja-se ainda a nota crítica 29, de José Mattoso, in Alexandre Herculano, ob. cit., t. II, 1. V., p. 547. Alexandre Herculano, ibidem, nota XX, pp. 619-620, A. D. Sousa Costa, ob. cit, pp. 146-149; 157-168.

${ }^{(25)}$ Sobre as campanhas e respectiva responsabilidade directiva cf. Monarquia Lusitana, Parte IV, 1. XIIII, cap. XVIIII-XXII, pp. 143-149; L. G. Azevedo, ob. cit., vol. VI, pp. 53-61; notas críticas 52, 57 e 77 de José Mattoso, in Alexandre Herculano, ob. cit., t. II, 1. V, pp. 549,550 e 553 .

${ }^{(2 \infty)}$ S Sobre a luta contra os sarracenos e o empenho da Santa Sé, ver A. D. Sousa Costa, ob. cit., notas 318 , p. 197; 324-325, pp. 204$-205 ; 390-398$, pp. $266-270 ; 533$, p. 425 e notas críticas 54,58 e 70 de José Mattoso, in Alexandre Herculano, ob. cit., t. II, l. V, pp. 549-550 e 552 .

$\left({ }^{37}\right)$ Ver, a título de exemplo, as contendas entre o bispo do Porto e os dominicanos e franciscanos em Fortunato de Almeida, História da Igreja em Portugal, vol. I, Barcelos, 1967, pp. 136-142; Luís G. Azevedo, ob. cit., vol. VI, pp. 64-69; A. D. Sausa Costa, ob. cit., pp. 405-406 e índice; cf. a bula Non absque dolore, de Honório III, 
a indisciplina e as guerras privadas entre nobres $\left({ }^{238}\right)$.

Estes parecem ser os acontecimentos que permitem compreender a situação do reino entre 1240-1245, ou mais propriamente com a crise de 1245 , mas cujo agravamento se acentuou com outros factos não menos importantes.

Entre estes destaca-se o casamento de D. Sancho II com D. Mécia Lopes de Haro, dama da rainha de Castela D. Berengária, viúva desde 1240 de Alvaro Peres de Castro, neta de Afonso IX, rei de Leão e parente em grau proibido de matrimónio de D. Sancho e que por informação do conde de Bolonha foi declarado nulo, por Inocêncio IV, em $1245\left({ }^{239}\right)$. Seguidamente registe-se uma nova e drástica intervenção pontifícia na vida política do país através das bulas Inter alia desiderabilia e Grandi non immerito, respectivamente de 20 de Março e de 24 de Julho de 1245 . Na primeira, dirigida ao próprio monarca, Inocêncio IV refere-se às desordens, queixas dos prelados e de outros e ao não cumprimento das promessas de $\mathrm{D}$. Sancho, e descreve, além disso, a anarquia do reino: roubos, casamentos em grau proibido, usurpação dos bens

de 18 de Dezembro de 1226, para as violências sobre as ordens monásticas, in Summa do Bullario Portuguez, n. ${ }^{\circ} 74$, p. 12; para os conflitos entre as dioceses e bispos da Guarda e Coimbra, Viseu e Guarda, bispos e cónegos ou outros clérigos, bispos e delegados pontifícios, prelados e mosteiros, ver nota crítica 28 de José Mattoso in Alexandre Herculano, ob. cit., t. II, l. V, p. 547. A. D. Sousa Costa, ob. cit., pp. 280-355. Este autor oferece-nos em muitas partes da sua obra descrições bastante pormenorizadas sobre este género de conflitos. Ainda sobre a violência e a anarquia que atingiram quase todo o reino neste período, vide José Mattoso, art. cit., desta mesma Revista em que o autor analisando os aspectos sociais, prova que tal situação se deve a uma crise política agravada por uma crise social motivada pelo desequilíbrio momentâneo entre o crescimento demográfico e os recursos económicos do país.

$\left.{ }_{(208}^{20}\right)$ Ver sobre as guerras privadas entre nobres ou porventura até guerras civis, Luís G. de Azevedo, ob. cit., vol. VI, pp. 18-29, onde se descreve a indisciplina e as rivalidades sangrentas, por vezes entre nobres; cf. ainda Alexandre Herculano, ob. cit., t. II, l. V, nota XVI, sobre as revoltas na menoridade de Sancho II, pp. 604-616 e p. 364 e respectivas notas críticas de José Mattoso, ibidem, pp. 653-654. Veja-se ainda sobre um novo possível levantamento dos fidalgos contra D. Sancho II, Luís Gonzaga de Azevedo, ob. cit., vol. VI, pp. 46-49, onde este autor defende que D. Afonso, primogénito do rei de Castela, entrou pela comarca de Braga acompanhado por João Fernandes de Lima e Rodrigo Froilaz para defesa de D. Sancho, o que seria inexplicável, segundo este autor, sem um novo levantamento dos fidalgos contra ele.

${ }^{(200)}$ A bula que trata desta nulidade é Sua nobis dilectus de 12 de Fevereiro de 1245, dirigida ao arcebispo de Compostela e de Astorga, mas com ordens de não excomungar o monarca, transcrita in D. Sousa Costa, ob. cit., nota 541, p. 429. 
eclesiásticos e de outros barões do reino, violação da excomunhão, homicídios, incêndios, etc., ameaçando o rei, caso não ponha termo a tamanha desordem, de tomar medidas ainda mais severas. $\mathrm{Na}$ segunda, enviada a todos os mestres, perceptores, priores, comendadores e frades do Templo e das ordens de Santiago e de Calatrava, etc., poucos dias depois do Concílio de Leão, onde fora excomungado e deposto Frederico II do trono alemão, expõe as graves queixas apresentadas contra D. Sancho e manda-lhes que obedeçam ao conde de Bolonha, como governador do reino a quem confiou toda a administração de Portugal $\left.{ }^{240}\right)$.

E finalmente a guerra civil iniciada em Agosto de 1245, em Porto - Gaia, travando-se uma verdadeira luta entre fidalgos que se levantaram contra D. Sancho sob o comando de Abril Peres e o valido do rei, Martim Gil de Soverosa, que os derrotou, perdendo a vida o próprio Abril Peres e o tio do rei, D. Rodrigo Sanches $\left.{ }^{241}\right)$.

Entretanto, os prelados e barões do reino que estiveram presentes no Concílio de Leão e pressionaram o papa a tomar aquela decisão, deslocaram-se a Paris, com excepção, ao que parece, de D. Aires Vasques, bispo de Lisboa e encontraram-se com o Conde de Bolonha a quem exigiram, em 6 de Setembro de 1245, o juramento de respeitar as liberdades eclesiásticas depois do qual, em Dezembro do mesmo ano, regressara o conde definitivamente a Portugal, impulsionando uma luta militar contra a facção de D. Sancho II $\left({ }^{242}\right)$.

(20) A bula Inter alia desiderabilia, enviada ao rei D. Sancho II, encontra-se in A. D. Sousa Costa, ob. cit., nota 542, pp. 431-433. A bula Grandi non immerito, encontra-se também, ibidem, nota 547, p. 436-439 e notas 548-550, p. 440. Esta bula também foi dirigida, em geral, aos barões, concelhos, cavaleiros e povo de Portugal e ainda aos bispos e outros prelados e clero. Ver também as duas bulas com o título, Cum ad curam, de 13 de Agosto de 1245, pedindo aos Franciscanos e Frades pregadores para se porem à disposição dos executores do mandato pontifício a fim de receberem o Conde de Bolonha, transerita, ibidem, também na nota 551 e 552 . A bula Grandi non immerito foi também dirigida em 17 de Agosto de 1245 a D. Pedro, filho de D. Sancho I, pela qual o papa lhe pede para assistir ao Conde de Bolonha (ibidem, nota 553, pp. 442-443).

(21) Quanto à Lide do Porto - Gaia e se foi um encontro ou dois, ver Luís G. Azevedo, ob. cit., pp. 100-102. Cf. nota crítica 98 de José Mattoso, in Alexandre Herculano, ob. cit., t. II, l. V, p. 556. Sobre a data da batalha (Agosto-Setembro de 1245) vide A. Almeida F'ernandes, Esparsos de Historia, Porto, 1970, pp. 97-103.

${ }^{(22)}$ A respeito da presença dos prelados e barōes no concílio de Leão, veja-se A. D. Sousa Costa, ob. cit., pp. 432-444. O juramento do Conde de Bolonha vem também publicado pelo mesmo autor, ob. cit., nota 554 , pp. 444-446. Sobre a posição no concílio de Leão 
Assim, em fins de 1245 já o conde de Bolonha, acompanhado do arcebispo de Braga e do bispo de Coimbra, se encontrava em Lisboa que depressa aderira às forças do partido de D. Afonso. Seguiram-se-lhe outros castelos, como Santarém, Alenquer, Torres Novas, Tomar. O castelo de Obidos foi cercado, acabando por ceder e Leiria tornou-se o centro de resistência do conde de Bolonha contra Coimbra, travando-se duros combates naquela cidade onde vieram a morrer cavaleiros de nomeada como Soeiro Gomes e Lourenço Fernandes. Os castelos da Covilhã e da Guarda deram-se também a D. Afonso. Mas em Coimbra as tropas fiéis a D. Sancho II, suspeitando que o cabido e o clero tivessem aderido ao partido do bolonhês, seguindo o seu bispo D. Tibúrcio, apoderaram-se dos bens da mitra, saquearam as casas dos membros do cabido e meteram outros nas prisões, pondo a ridículo a dignidade episcopal.

Verificaram-se, então, por todo o reino, principalmente no norte e nas Beiras, certos episódios de resistência e de traição em reacção à decisão e intervenção de Inocêncio IV e à substituição do rei pelo Conde de Bolonha.

Entretanto D. Sancho II resolveu pedir auxílio a D. Afonso, filho primogénito do rei de Castela que para além de ter feito certas diligências junto do papa para defender D. Sancho, entrou em Portugal em 1246, apoderando-se dos castelos da Covilhã e da Guarda, dirigindo-se posteriormente com as suas tropas para Leiria, onde provocaram devastações e travaram um combate, havendo prisioneiros e mortos no campo de batalha. Excomungados por ordem do arcebispo de Braga e do bispo de Coimbra, regressaram, finalmente, a

em relação a D. Sancho II, de D. Aires Vasques, bispo de Lisboa e sucessor de D. João Rolis, ver D. Rodrigo da Cunha, Historia Eclesiastica da Igreja de Lisboa, Parte II, Lisboa, 1642, cap. XXXXV-XXXXVI, pp. 160-168, onde transcreve o discurso de D. Aires, em total oposição aos restantes bispos e barões que pressionavam o papa em ordem à deposição de D. Sancho II.

Contudo Alexandre Herculano, ob. cit., t. II, 1. V, nota 227, pp. 509-510 é de opinião que este mesmo discurso carece de fundamento e não merece crédito. O cardeal Saraiva, Obras Completas, t. I, Lisboa, Imprensa Nacional. 1872, pp. 387-392 transcreve-o com as seguintes palavras: "Pareceo-nos digno, não só de se conservar em memoria, mas também de se incorporar na história daquele infeliz príncipe». J. Veríssimo Serrão, História de Portugal, vol. I, Lisboa, 1977, pp. 132-133 conclui que a autoridade da fonte permite crer na informação e transcreve-o também, em parte. José Mattoso, nota crítica 103, in Alexandre Herculano, ob. cit., t. II, l. V, p. 557, diz que não era muito verosímil que um bispo galego, imposto à força, havia apenas um ano, ao cabido de Lisboa pelo arcebispo de Compostela e pelo papa, viesse defender tão calorosamente um rei que ele mal conhecia. 
Castela, levando consigo D. Sancho II para Toledo, onde vem a morrer no mês de Janeiro de 1248, passando o Conde de Bolonha, por este mesmo facto, a governar como rei de Portugal $\left({ }^{243}\right)$.

As dissensões entre o clero e D. Afonso III, que por certo comprometiam a Convenção de Paris $\left({ }^{244}\right)$, principiaram logo no início do seu governo, procurando o monarca dar-lhes solução nas Cortes de Guimarães, celebradas em 11 de Junho de 1250 , perante as queixas formuladas pelo arcebispo de Braga D. João Egas, sobre os agravos de ordem geral feitos ao clero, por D. Julião, bispo do Porto, D. Rodrigo, bispo da Guarda e por D. Egas, bispo de Coimbra, estando ainda presente Mestre Manfredo, capelão do papa e núncio em Espanha $\left({ }^{245}\right)$. Contudo, o acordo a que se chegou nas referidas cortes, pouco adiantou, pois passado algum tempo recomeçaram as contendas com D. Julião Fernandes, bispo do Porto.

Nas Cortes, queixara-se já o bispo de que o monarca obrigava os cidadãos a servir no exército real, a pagar fossadeira, fazendo-lhe promessas de os defender contra a pessoa do próprio prelado; que ocupava violentamente as casas dos clérigos e cidadãos e usurpava da jurisdição não só por impedir actos da competência do porteiro e o livre exercício do sobre-juiz, mas também por espoliar templos e bens,

(213) Inocêncio IV recomenda ao Conde de Bolonha, pela bula Sincere devotionis, de 24 de Junho de 1246 se atenha ao teor das bulas na administração do reino de Portugal, sem lesar os direitos de D. Sancho II, e do Infante D. Afonso de Castela que se queixara do conde ter invadido militar e violentamente o reino de Portugal, espoliando desumanamente D. Sancho (cf. A. D. Sousa Costa, ob. cit., notas $555-556$, pp. 446-448.

(24) Diz Frei António Brandão que antes de se entregar ao infante a administração de Portugal quiseram os prelados do reino e mais portugueses presentes em França que fizesse juramento de guardar muitas coisas importantes que lhe apontaram, e deviam ser as que seu irmão não provia: e se eles foram liberais em pedir, não foi $o$ infante escasso em prometer (Monarquia Lusitana, Parte IV, l. XIV, cap. XXVII, p. 157 ; a convenção vem transcrita na íntegra, ibidem, pp. 158-159 e Escritura XXXV, pp. 283-284).

${ }^{(25)}$ Sobre as Cortes de Guimarães ver a nota bastante esclarecedora n. 26, de José Mattoso, in Alexandre Herculano, ob. cit., t. III, 1. VI, p. 202. Os artigos gerais referentes ao clero vêm publicados in Portugaliae Monumenta Historica. Leges et Consuetudines, Lisboa, 1856, pp. 184-190. Para toda a presente questão cfr. José A. Ferreira, Memorias Archeologico-Historicas da cidade do Porto, t. I, Braga, 1923, pp. 237-240 e António Cruz, «Os bispos Senhores da cidade: II, de D. Pedro Salvadores a D. Vasco Martins», in História da Cidade do Porto (dir. por A. Cruz e Damião Peres), I, Porto, 1962, pp. 197-204. 
como sucedera com uma propriedade no termo de Pindelo e a uma ermida em Fremedo $\left({ }^{240}\right)$.

Mas a principal questão que se levantou entre o prelado do Porto e o rei foi acerca dos direitos que pagavam as mercadorias que desciam o Douro e do lugar onde deviam desembarcar, se em Gaia, burgo pertencente ao rei, se na cidade episcopal do Porto ${ }^{247}$ ). Em ordem a uma possível solução, D. Afonso III ordenou se procedesse a um inquérito, mas não se chegou a acordo, visto que $D$. Julião pretendia que se mantivesse a composição feita entre D. Sancho II e D. Pedro Salvadores $\left({ }^{248}\right)$. E sentindo-se ofendido com tal inquirição que de certo modo ia contra a concordata estabelecida entre o seu predecessor e D. Sancho II, recorreu à força armada, provocando motins que, no dizer de Herculano "perturbaram o reino inteiro» $\left({ }^{249}\right)$. Então D. Afonso III, reagindo contra esta atitude do prelado, marchou contra o Porto e ocupou militarmente a cidade, exigindo que lhe fossem entregues as chaves do castelo e das torres ${ }^{(250}$ ). Entretanto D. Julião, perante a violência do rei, teve de ceder e sujeitou-se à multa de seis mil e quinhentas libras em castigo dos distúrbios que

${ }^{(216)}$ Ver Portugaliae Monumenta Historica. Leges et Consuetudines, p. 144.

(247) Corpus Codicum, vol. II, pp. 47-49; Alexandre Herculano, ob. cit., t. III, l. VI, p. 45, apresenta ainda outro motivo desta contenda: o facto de os habitantes do burgo episcopal serem obrigados a contribuir para a guerra do Algarve e do rei querer recompensar com benefícios eclesiásticos da igreja serviços políticos prestados nas últimas lutas civis.

$\left.{ }^{248}\right)$ A composição entre D. Sancho II e D. Pedro Salvadores vem transcrita em A. D. Sousa Costa, ob. cit., nota 524, pp. 413-418. Ver ainda as notas 525 e 526, pp. 418-419, onde o mesmo autor transcreve as duas bulas com o mesmo título Cum a nobis petitur de 6 de Julho de 1254. Sobre a confirmação da composição e provavelmente sobre a aprovação da mesma em 2 de Fevereiro de 1245 (cf. Summa do Bullario Portuguez, n..$^{\circ} 1936$, p. 320; ver a mesma referência no Censual do Cabido da Sé, pp. 19-20; cf. também sobre o inquérito Corpus Codicum, vol. II, pp. 45, 47-48.

(219) Alexandre Herculano, ob. cit., t. III, 1. VI, p. 46. Cf. António Cruz, ob. cit., p. 200.

$\left({ }^{200}\right)$ Segundo uma carta que mais tarde D. Vicente Mendes, sucessor de D. Julião, dirigiu ao rei D. Dinis em 14 de Abril de 1289, o alcaide do burgo episcopal recusou-se a entregar as chaves do castelo e foi depositá-las no altar-mor da catedral, declarando ao monarca que as fosse ali buscar, mas que ele não quebraria o preito que fizera ao seu senhor. Vide transcrição por Torquato de Sousa Soares, in Subsídios para o estudo da organização municipal do Porto durante a Idade Média, Barcelos, 1935, pp. 71-72; cf. também António Cruz, ob. cit., p. 200; Alexandre Herculano, ob. cit., t. III, l. V, p. 46; José A. Ferreira, ob. cit., p. 239, nota 3. 
causara e partiu para Roma $\left({ }^{251}\right)$. Perante as dificuldades que se levantavam, D. Afonso III convocou novas cortes em Leiria para os princípios de 1254, mandando então lavrar aos 17 de Março do mesmo ano uma Carta Régia em que, de acordo com o Vigário Geral da diocese que representava o bispo ausente, ficaram estabelecidas as seguintes condições: as embarcações que viessem do Alto Douro carregadas de vinho, madeira e outras mercadorias acostariam duas partes à margem direita do rio e a outra à margem esquerda; as que viessem da França ou de outras terras com pão, madeira, ferro ou outros produtos, metade acostaria na cidade episcopal do Porto e outra metade em Gaia; para os barcos dos moradores do Porto ficava livre a acostagem à margem direita $\left({ }^{252}\right)$.

D. Afonso III tomou ainda outras medidas, como a fixação da venda livre do sal e a restituição de algumas propriedades pertencentes à Sé portuense. Contudo, D. Julião, após o seu regresso de Roma, recusou o acordo estabelecido nas cortes de Leiria, por estar em contradição com a confirmação que obtivera do papa através da bula Cum a nobis, de 6 de Julho de 1254, dada à composição celebrada entre D. Sancho II e D. Pedro Salvadores, e ainda por se sentir apoiado por uma nova bula pontifícia, Cum prout asseritur, de 9 de Agosto do mesmo ano, pela qual o papa não só intimava lhe fossem entregues todos os seus rendimentos, mas proibia ao monarca todo e qualquer exercício de jurisdição na cidade $\left({ }^{253}\right)$.

Porém, o rei prosseguiu firme nos seus intentos, passando a questão para os sucessores de $D$. Julião que veio a falecer em 31 de Outubro de $1260{ }^{(254)}$.

Quando D. Afonso III, em 2 de Abril de 1265, publicou

(251) Cf. Monarquia Lusitana, Parte V, Escritura XII, p. 310.

(202) Cf. João M. Silva Marques, Descobrimentos portugueses, Lisboa, 1944, vol. I, p. 7, onde transcreve o doc. "Carta qualiter nanes et barquete debent desencarregari in Portu». Ver também António Cruz, ob. cit., p. 201.

${ }_{(203)}$ A bula Cum a nobis petitur, dirigida ao bispo e cabido do Porto, vem transcrita por A. D. Sousa Costa, ob. cit., nota 525, pp. 418-419. E como já referimos, este mesmo autor transcreve na íntegra, também, toda a composição, na nota 524, pp. 413-418. Ver in Quadro Elementar, vol. IX, pp. 172-173 e ainda Summa do Bullario Portuguez, n. ${ }^{\circ}$ 1936, pp. 320-321. A bula Cum prout asseritur encontra-se parte no Quadro Elementar, IX, pp. 173-174 e na Summa do Bullario Portuguez, n. ${ }^{\circ} 1938$, p. 321.

(24) Cf. o testamento de D. Julião Fernandes, no Censual do Cabido da Sé do Porto, p. 396. Cfr. António Cruz, ob. cit., p. 204. 
as leis da fazenda pública, resultado das inquirições de 1258 , provocou forte descontentamento e tenaz resistência, principalmente no clero que passou a ver no rei o seu perseguidor e o maior opositor às suas imunidades eclesiásticas e privilégios $\left({ }^{255}\right)$.

Neste sentido a maior parte dos historiadores apontam como causa próxima das longas desavenças entre o rei e o clero, durante todo o reinado de $\mathrm{D}$. Afonso III, tais determinações, que, no fundo, compendiam no corpo do $200^{\circ}$ artigo da extensa memória de queixas que os prelados portugueses apresentaram ao papa Clemente IV, contra o monarca e que é formulado do seguinte modo: "Que (o rei) ordenava se fizessem pelo reino inquirições acerca dos bens e padroados das igrejas, em prejuízo geral do clero sem chamar os donos desses bens nem os padroeiros, e que, se por semelhantes inquirições ilícitas e iníquas achava que lhe pertenciam alguns padroados ou propriedades, os tomava para si, embora ofendesse a posse imemorial expulsando os párocos, quando, dada essa hipótese, não era por inquéritos que se devia resolver a questão, mas judicialmente no foro eclesiástico» $\left.{ }^{256}\right)$.

Seja como for o que é certo é que o arcebispo de Braga, D. Martinho Geraldes (1256-1271), D. Vicente Mendes, bispo do Porto (1261-1296), D. Egas Fafes, bispo de Coimbra (1246-1267), D. Rodrigo Fernandes, bispo da Guarda (1250-1267), D. Pedro Anes, bispo de Lamego (1257-1270), D. Mateus, bispo de Viseu (1254-1268), D. Martinho, bispo de Evora (1248-1266) $\left({ }^{257}\right)$, depois de esgotados, ao que parece, todos os meios para conseguirem do rei medidas mais suaves, retiraram-se do país, lançaram o interdito no reino e afastaram-se para a

(25) Sobre a publicação das leis da fazenda ver Portugaliae Monumenta Historica - Leges et consuetudines, I, p. 215.

${ }^{250}$ ) Os quarenta e três artigos sobre as queixas dos bispos encontram-se em Alexandre Herculano; ob. cit., t. III, 1. VI, pp. 131-140. Cf. também Fortunato de Almeida, ob. cit., t. I, pp. 189-193 e ainda Quadro Elementar, t. IX, pp. 187-197, onde é reproduzido o mesmo articulado. Sobre os motivos que levaram as lutas entre D. Afonso III e o clero ver as notas informativas e críticas de José Mattoso, n. ${ }^{\circ}$ 94, 96, 97, in Alexandre Herculano, ob. cit., t. III, l. VI, p. 212. E ainda relativamente às contendas entre o clero e o rei ver Monarquia Lusitana, Parte IV, 1. XV, e XXXIX-XLI, pp. 238-247.

${ }^{(257)}$ Cf. Miguel de Oliveira, Historia Eclesiastica de Portugal, Lisboa, 1958, pp. 431-447. Cf. nota crítica 80 de José Mattoso, in Alexandre Herculano, ob. cit., t. III, 1. VI, p. 210 e ainda Alexandre Herculano, ob. cit., t. III, l. VI, pp. 126-127. O bispo de Lamego que já se encontrava na Cidade de Rodrigo adoeceu e regressou à sua diocese, enviando um procurador e o mesmo fez o bispo de tvora tendo partido para Roma os outros cinco prelados. Ver ainda as notas críticas de José Mattoso, 99-102, ibidem, pp. 212-213. 
Cúria Romana ${ }^{258}$ ), de tal modo que em 1267 apresentaram ao papa Clemente IV, que se encontrava em Viterbo, o longo articulado em que o rei era acusado de violências na administração civil e de atentados contra a liberdade, imunidades e privilégios eclesiásticos, ${ }^{259}$ ) de confiscação de bens, prisões, espoliações, apropriação de rendimentos, recusa do pagamento dos dízimos reais; de pesadas exacções; de matar à míngua, assassinar ou de enforcar os presos; de encarcerar os bispos nas igrejas ou mosteiros; de torturar os servos dos bispos; de infligir maus tratos aos clérigos; de provocar sequestros, etc.

Dos quarenta e três artigos figuram três que eram apenas relativos à diocese do Porto ou seja o $29 .^{\circ}$, o $30 .^{\circ}$ e o $31 .^{\circ}$, pelos quais se acusava o rei de fundar novas povoações junto das cidades e vilas pertencentes à Igreja; de nomear oficiais seus, sem permissão dos bispos, os súbditos destes, recebendo-os assim por vassalos; e de impor serviços aos pescadores súbditos da Igreja, o que era contra as liberdades desfrutadas nos reinos anteriores $\left({ }^{260}\right)$.

D. Afonso III procurou defender-se das acusações que lhe eram feitas contrapondo ao libelo dos bispos uma declaração solene dos concelhos em que se defendiam os actos do rei e se teciam encómios à sua administração. E sabendo que Clemente IV se empenhava na realização de uma cruzada ao Oriente, declarou-se pronto a partir para a cruzada o que levou o papa a conceder-lhe, durante três anos, determinadas esmolas, legados e bens e mandou absolver os excomungados que se alistassem, concedendo indulgências a todos os que se empenhassem em tão grande empresa $\left({ }^{261}\right)$.

$\left.{ }^{258}\right)$ Cf. D. Rodrigo da Cunha, História Eclesiástica da Igreja de Lisboa, Parte II, cap. LII e seg.

${ }^{(250)}$ Cf. Fortunato de Almeida, ob. cit., p. 189.

${ }^{(300)}$ Cf. António Cruz, ob. cit., p. 206. Ver estes artigos em Alexandre Herculano, ob. cit., t. III, l. VI, pp. 136-137 e Quadro Elementar, t. IX, pp. 192-193.

(281) As bulas que se referem a este projecto de cruzada são as seguintes: Ad liberationem, de 29 de Julho de 1268, dirigida ao rei de Portugal; Ad liberationem Terrae Sanctae, de 30 de Julho, também de 1268, enviada aos Priores dos Pregadores da diocese de Lisboa e aos Guardiães das Ordens Menores das dioceses de tvora e da Guarda e mais três com o mesmo título Ad liberationem Terrae Sanctae, enviadas aos mesmos destinatários e na mesma data, embora de conteúdo diverso e a bula Cum Carissimus também de 30 de Julho de 1268 endereçada aos mesmos, concedendo-lhes a faculdade de absolver os que saíssem com o rei para a Terra Santa. Cf. estas bulas em Quadro Elementar, t. IX, pp. 199-202 e Summa do Bullario Portuguez, n. 1975 e 1976, p. 329. Perante esta atitude de D. Afonso III o papa Clemente IV limitou-se pela bula $Q u i$ de salute cunctorum, de 31 de 
Por outro lado, o rei português informava ainda Clemente IV, provavelmente em 1268, que não guardava qualquer ressentimento aos prelados, afirmando-lhe até que podiam regressar ao reino, sem receio de perigo para o que lhes concedia uma trégua de quinze anos $\left({ }^{262}\right)$.

Porém, o bispo do Porto, D. Vicente Mendes, talvez mais queixoso, como nenhum outro prelado, das violências do rei que tinha mandado até enforcar em Gaia o alcaide menor do Porto, Miguel Lourenço, sobrinho do bispo, e ainda outro vassalo seu, Pascásio Ferrario, não só obteve a confirmação da doação da cidade feita pela rainha $D$. Teresa, inclusa na bula Justis petentium, de 11 de Junho de 1268, mas também que o papa lhe confirmasse em 5 de Novembro do mesmo ano, pela bula Venerabilis frater, a concórdia feita entre D. Sancho II e D. 'Pedro Salvadores, tornando assim sem efeito, as transacções feitas nas cortes de Leiria, em 1254, entre D. Afonso III e o vigário do prelado do Porto $\left({ }^{263}\right)$.

Entretanto, Clemente IV morre em 29 de Novembro de 1268, ficando comprometida a projectada vinda de Guilherme Folquini a Portugal para ouvir as queixas e resolver as questões como delegado pontifício, tendo o seu sucessor, Gregório X, sido eleito em 1272, mas nesta data, dos prelados adversários de D. Afonso III, só dois sobreviviam, Vicente Mendes, bispo do Porto e Mateus, bispo de Viseu que fora transferido para a Sé de Coimbra.

D. Vicente Mendes permanece em Roma, mas, em breve, novas queixas apresentadas por outros prelados do reino vêm somar-se às suas, visto que a situação da Igreja em Portugal

Julho de 1268, a recordar-lhe, moderadamente, as acusações dos prelados e a aconselhar-lhe que se emendasse (cf. Quadro Elementar, t. IX, pp. 202-204 e Summa do Bullario Portuguez, n. ${ }^{\circ}$ 1978, p. 330, ref. in Augustus Pothast, ob. cit., n. ${ }^{\circ} 20431$ ). Ainda em 31 de Julho de 1268 pela bula Negotio quod manda aos Guardiães da Ordem dos frades menores em Santarém e Leiria que anunciem a suspensão, por seis meses, das sentenças de interdito fulminadas pelos prelados (cf. Quadro Elementar, t. IX, p. 202 e Summa do Bullario Portuguez, n. ${ }^{\circ}$ 1977, p. 330). Em 13 de Setembro do mesmo ano endereça a bula Super gravaminibus a Guilherme Folquini, seu capelão, encarregando-o de examinar em Portugal as queixas de ambas as partes e dar-lhes solução, suspendendo, para tanto, por seis meses, as sentenças dos prelados (cf. Quadro Elementar, t. IX, p. 204 e Summa do Bullario Portuguez, n. ${ }^{\circ} 1979$, p. 330 e ref. em João Pedro Ribeiro, Dissertações chronologicas e criticas, t. V, p. 247)

t. IX, pp. 197-198.

${ }^{\left({ }^{22}\right)}$ A carta está publicada, em parte, no Quadro Elementar,

(2ळ) Cf. Quadro Elementar, t. IX, p. 204 e Summa do Bullario Portuguez, n. ${ }^{\circ} 1980$, p. 330. 
não melhorava ${ }^{264}$ ). Assim, Gregório X, em 28 de Maio de 1273, dirige a D. Afonso III a bula Scire debes onde relata, de uma maneira impressionante, as ofensas mais recentes à Igreja, como o apossamento dos créditos e proventos de várias Sés, a apropriação da jurisdição, a ocupação de igrejas paroquiais e do seu padroado, de aldeias, casas, propriedades, direitos de algumas dioceses, a espoliação dos dízimos eclesiásticos, a doação de bens eclesiásticos a cavaleiros e a leigos, as opressões pelos seus sobrejuizes sobre conventos, prelados, cabido e pessoas eclesiásticas, o desrespeito pelo privilégio de foro, a confiscação de bens aos judeus e sarracenos convertidos e a sua redução à escravidão, a exigência de parte dos frutos das terras dos clérigos e igrejas, etc.. Gregório $\mathrm{X}$ concluía a bula pedindo ao rei que deixasse de ofender a Igreja, os seus ministros e a liberdade eclesiástica e que obrigasse os súbditos a imitá-lo, informando-o de que tinha encarregado o Prior dos Pregadores e o Custódio e Guardião dos frades menores de lhe apresentarem as cartas apostólicas $\left({ }^{265}\right)$.

Porém, o monarca, como não queria receber os delegados apostólicos nem entrar em conflito mais agudo com a Santa Sé, lançou mão de processos dilatórios, desculpando-se ora com os negócios do Estado, ora com motivos de doença $\left.{ }^{(266}\right)$. Por último, decidiu convocar as cortes em Santarém em fins de 1273, visto as acusações versarem também sobre assuntos de administração geral, tendo os delegados pontifícios conseguido audiência do monarca antes da abertura da assembleia. Depois de D. Afonso III prometer perante as cortes cumprir os mandatos do papa, foi então nomeada uma comissão para averiguar o fundamento das acusações, constituída pelo bispo de Évora, D. Durando Paes, Estêvão Annes, chanceler e D. João Peres de Aboim, mordomo-mor que não

(24) Cf. Fortunato de Almeida, ob. cit., p. 194 e J. Augusto Ferreira, ob. cit., p. 257.

(20) A bula Scire debes vem transcrita no Quadro Elementar, t. IX, pp. 205-209; ver uma breve ref. em Summa do Bullario Portuguez, n. ${ }^{\circ} 1981$, pp. 330-331. Ver ref. in Augustus Pothast, ob. cit., m. ${ }^{\circ}$ 20742.

Gregório $\mathbf{X}$ enviou mais duas bulas ao Prior dos Pregadores € ao Custódio e Guardião dos Frades Menores de Lisboa: Cum Charissimus in Christo, de 28 de Maio de 1273 e Volumus et praesentium, de 2 de Junho do mesmo ano, dando-lhes o encargo de apresentarem as cartas apostólicas ao rei e poderes para suspenderem por sete meses a excomunhão lançada pelos prelados (cf. Quadro Elementar, t. IX, pp. 210-211 e Summa do Bullario Portuguez, n. ${ }^{\circ} 1982$, p. 331; e ainda Monarquia Lusitana, parte IV, l. V, e XXXIX, pp. 240).

${ }^{(20)}$ Esta conclusão infere-se da bula De Regno Portugaliae (cf. nota seguinte $n .^{\circ} 268$ ). 
demorou a proferir as suas decisões favoráveis ao rei $\left({ }^{267}\right)$. Gregório X, publicou então a extensa bula De Regno Portugaliae, com data de 4 de Setembro de 1275, em que lhe recordava o juramento de Paris, censurava o seu procedimento e as farsas que usara para com os delegados apostólicos e ordenava que cumprisse não só o seu juramento mas desse satisfação e fizesse as reparações devidas, marcando-lhe um prazo de três meses para cumprir tudo. Impunha-lhe, além disso, a pena de interdito local e se não produzisse efeito dentro de um certo tempo, fulminá-lo-ia com a excomunhão maior, seguindo-se, caso fosse necessário, o interdito geral e se nem assim se emendasse desligaria os portugueses do juramento de lhe obedecerem e the tiraria a coroa $\left({ }^{208}\right)$.

Por motivos desconhecidos esta bula não foi comunicada ao rei e entretanto Gregório $\mathrm{X}$ falecera a 10 de Janeiro de 1276, sucedendo-lhe, com breves pontificados, Inocêncio V e Adriano V, até que em 13 de Setembro de 1276 subiu ao sólio pontifício um papa português, Pedro Julião ou Pedro Hispano, com o nome de João XXI ${ }^{(269)}$.

Todavia Inocêncio $\mathrm{V}$, tinha confiado ao franciscano espanhol, Frei Nicolau, a missão de núncio em Portugal, mas este serviu-se de todos os pretextos para adiar a sua vinda. Assim, João XXI, logo em 15 de Outubro de 1276 envia a bula Felicis recordationis onde transcreve a bula De Regno Portugaliae de Gregório X, dirigida a Frei Nicolau, dando-lhe ordens terminantes para intimar o monarca ao cumprimento das resoluções de Gregório X $\left.{ }^{(2 \pi 0}\right)$. E realmente, em 6 de Fevereiro de 1277 o núncio, Frei Nicolau, obtinha uma audiência do rei

$\left({ }^{207}\right)$ Cf. Monarquia Lusitana, Parte IV, 1. XV, e XL-XLI, pp. 240-244, onde além da descrição dos factos se publica a carta régia da nomeação da comissão.

(208) A bula De Regno Portugaliae vem transcrita, quase na integra, no Quadro Elementar, t. IX, pp. 214-219 e parte na Summa do Bullario Portuguez, n. 1987 , p. 332. Cf. também Monarquia Lusitana, Parte IV, 1. XV, e XLI, pp. 242-244, Rerum Memorabilium, II, fl. 56, do Arq. Dist. de Braga, cuja fotocópia existe no Instituto de Paleografia da Faculdade de Letras da Universidade de Coimbra.

${ }^{(280)}$ Por morte do papa Adriano V, o conclave reunido em Viterbo, escolheu-o, por unanimidade e foi coroado papa em 20 de Setembro de 1276, na catedral de S. Lourenço de Viterbo com o nome de João XXI. Em 17 ou 20 de Maio de 1277 faleceu e foi sepultado na Basílica de São Lourenço de Viterbo.

O duque de Saldanha, embaixador de Portugal em Roma, mandou-lhe colocar no túmulo a seguinte inscrição: Joannes Lusitanus XXI. Pont. Max. Falecido no oitavo mês do seu pontificado.

${ }^{(270)}$ A bula Felicis Recordationis encontra-se na Torre do Tombo, Mitra de Braga, cx. 2, rolo 6, em cópia de Fevereiro de 1277 
e nela apresentou as bulas que o papa lhe confiara, repetindo as conferências com D. Afonso III durante o mês de Março. Certificando-se, no entanto, que era inútil continuar o diálogo com o monarca, dirigiu-se à Sé e perante o clero e o povo fez a publicação solene das disposições das bulas que afixou às portas da Catedral, dirigindo-se seguidamente para outras cidades onde renovou o mesmo acto.

Em 3 de Março de 1277, João XXI envia ao próprio rei a bula Jucunditatis et exultationis em que lhe comunica que tem especial afecto por ele, por ser português, e um sincero desejo de o ajudar com os favores da Santa Sé, afirmando-lhe que não pretendeu lesar os direitos reais, ao privar dos benefícios Gs clérigos que não tinham sido providos canonicamente e exorta-o a praticar a virtude e a defender a Igreja $\left({ }^{271}\right)$.

Porém, em Maio de 1277, João XXI falecera.

O rei, que até então se mostrara impassível, mandou chamar o núncio pouco tempo depois de receber a notícia da morte do papa, travando um vivo diálogo com Frei Nicolau, mas desconhecendo-se, porventura, os resultados $\left({ }^{272}\right)$. Sabe-se apenas que em 17 de Janeiro de 1279 chamou à sua presença D. Durando Paes, bispo de Évora, afecto à corte, os vigários do bispado de Lisboa e os priores dos Pregadores e Frades menores e ainda os fidalgos da corte e que perante todos se submeteu à jurisdição da Igreja, prometendo aceitar e cumprir a vontade da Santa Sé, estando ainda presente o seu filho D. Dinis que igualmente prometeu dar execução às disposições de seu pai que veio a falecer pouco depois, em 16 de Fevereiro de 1279.

e ainda in Rerum Memorabilium, II, fl. 55 e seguintes, do Arquivo Distrital de Braga, cuja cópia existe no Instituto de Paleografia da Faculdade de Letras de Coimbra.

${ }_{(2 i 1)}$ Ver bula Jucunditatis et exultationis in Quadro Elementar, t. IX, pp. 220-221; Summa do Bullario Portuguez, n.o 1988, pp. 332-333. Cf. notas críticas 115 e 116, de José Mattoso, in Alexandre Herculano, ob. cit., t. III, l. VI, p. 214. A bula encontra-se na íntegra na Biblioteca da Ajuda, Rerum Lusitanicarum, vol. LI, Symmicta Lusitanica, t. XLIV, pp. 537-541.

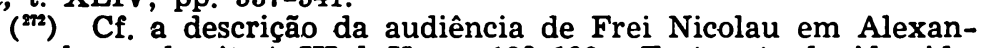
dre Herculano, ob. cit., t. III, l. V, pp. 183-190 e Fortunato de Almeida, ob. cit., pp. 198-200 
(Página deixada propositadamente em branco.) 
2.

O único conflito violento da fase inicial de governação de D. Dinis que ficou registado em documentos coevos, foi o que opôs o rei ao seu irmão D. Afonso, possuidor de um vasto senhorio confinante com Castela e que englobava as povoações de Vide, Marvão, Portalegre e Arronches $\left(^{1}\right)$. Por meados de Abril de $1281\left({ }^{2}\right)$ o rei iniciava o cerco de Vide,

(1) Não estão ainda devidamente esclarecidos os confrontos que tiveram como cenário a corte portuguesa nos primeiros anos do reinado de D. Dinis. Parece no entanto certo que a sua política de alianças no contexto ibérico - ligação a Aragão e apoio a D. Sancho contra Afonso $\mathrm{X}$ - e a nova orientação dada à resolução dos problemas internos - as primeiras tentativas de concórdia com o clero - originaram clivagens na corte entre a parcialidade de D. Afonso III que nela se mantinha e os homens que se agregavam à volta do novo monarca. $O$ Livro de Linhagens do conde $D$. Pedro conservou a memória da inimizade de D. Dinis por Martim Vasques da Cunha, alcaide de Celorico de Basto - povoação dada em arras à rainha $\mathrm{D}$. Beatriz, mulher de Afonso III - "porque doestára huum bispo de Lixboa que era seu privado, que avia nome dom Domingos Jardo». A este Domingos Jardo se refere também uma notícia de carácter analístico, inserida insolitamente na Chancelaria de D. Dinis, ao qual diz terem sido restituídos os selos de D. Dinis, pelo próprio rei no ano de 1281, dia 19 de Julho, sábado, entre a hora nona e as vésperas, data em que o rei se dirigia para Lisboa após ter cercado seu irmão D. Afonso em Arronches. Estes elementos denotam alguma instabilidade e indefinição do poder que D. Dinis implicitamente reconhece em 1283 ao revogar, por carta de 26 de Dezembro, todas as doações e coutos que fizera até então, mostrando ao mesmo tempo que não guardava boas recordações dos tempos anteriores. Cf. Livro de Linhagens do Conde D. Pedro (ed. José Mattoso, Lisboa, 1980, II/2, pp. 78-80); Balbina Rodrigues de Almeida, D. Dinis. Breve Estudo da sua Chancelaria (tese policopiada que abrange os anos de 1280-1283), Coimbra, 1969, pp. 88 e CLXV.

$\left({ }^{2}\right)$ Doc. cit. por Fr. Francisco Brandão, Monarquia Lusitana, V, p. 61 v. O primeiro documento da Chancelaria de $D$. Dinis que o dá com assento em Vide, traz a data de 22 de Abril de 1281. 
povoação a que o infante se acolhera com seus vassalos após a ter fortificado. A documentação aragonesa dada a conhecer por Fernando Felix Lopes $\left({ }^{3}\right)$ esclarece melhor o alcance peninsular deste conflito dando a entender que ele complicaria as negociações de paz então encetadas entre o rei de Aragão e Afonso $\mathrm{X}$. Tal facto terá contribuído para a rápida solução da contenda pois em Junho, após uma paragem em Estremoz, o rei regressava a Lisboa onde se encontrava já a 5 de Agosto ( $\left.{ }^{4}\right)$.

Nas negociações encetadas nos finais do ano e inícios de 1282 o infante comprometeu-se a ficar como vassalo do rei deixando-se armar cavaleiro por ele e recebendo a quantia anual de 35000 libras $\left({ }^{5}\right)$.

A paz não foi no entanto muito duradoira. $O$ infante, após a morte de Afonso $\mathrm{X}$ em 1284, continua a apoiar as facções rivais do novo rei Sancho IV, e D. Dinis, em 1287 e após conversações com este no Sabugal, cerca-o em Arronches. $O$ cerco durou cerca de um mês pois a 6 de Novembro o rei já se encontrava à vista de Arronches e a 13 de Dezembro seguinte compunha-se com o infante em Badajoz $\left({ }^{6}\right)$.

$\left({ }^{3}\right)$ Fernando Felix Lopes, «Data e circunstâncias do casamento da Rainha Santa Isabel», Itinerarium, IX, 40, Braga, 1963, pp. 193-219.

(4) Cf. Itinerários Régios Medievais, I, Itinerários Del-Rei D. Dinis, 1279-1325, Lisboa, 1962, p. 16. A restituição dos selos a Domingos Jardo (v. nt. 1) efectuada nesta altura, o que permite pensar que eles estariam na posse do infante D. Afonso, pode tornar verosímil a justificação para a contenda entre ambos os irmãos surgida nas fontes narrativas da primeira metade do séc. XIV e desaparecida temporariamente das crónicas a partir da obra do conde de Barcelos. Com efeito, o Breve Chronicon Alcobacense (ed. Alex. Herculano, Scriptores, p. 21) e a Crónica galego-portuguesa de Espanha e Portugal (através de Acenheiro) referem as pretensões do infante $\mathrm{D}$. Afonso ao trono sob a alegação de ilegitimidade de $\mathrm{D}$. Dinis, pelo facto de este ter nascido quando a primeira mulher de Afonso III, Matilde, condessa de Bolonha, ainda vivia. Para uma posição contrária vide Fernando Felix Lopes, «O infante $\mathrm{D}$. Afonso irmão de el-rei D. Dinis», Itinerarium, X, 44, Braga, 1964, pp. 192-193. Este autor baseia o seu raciocínio no facto de Matilde ter morrido «em 1258 ou talvez já em 1259», quando efectivamente ela morreu em 14 de Janeiro de 1261, cerca de nove meses antes do nascimento de D. Dinis, podendo portanto este ter sido concebido ainda em vida daquela. Sobre a data da morte da condessa de Bolonha, Domingos Affonso, Matilde, «Verbo. Enciclopédia Luso-Brasileira de Cultura», vol. 12.0, Lisboa, 1971, p. 1816.

(5) Balbina Rodrigues de Almeida, ob. cit., pp. 192-199.

(') Itinerários Régios Medievais..., p. 28. 
Por um dos documentos da composição entre ambos $\left({ }^{7}\right)$ o infante aceitava a troca do castelo e vila de Marvão por Armamar, próximo de Visẹu. Com esta troca e na sequência da sua transferência, como tenente, da Guarda para Viseu e Lamego, verificada por meados de 1287 , o rei procurava já afastá-lo da região fronteiriça onde se situavam os seus domínios, tentando evitar situações idênticas às que tinham antecedido o cerco de Arronches.

No entanto a morte de D. Sancho IV, rei de Castela, em 1295, e a subida ao trono de seu filho D. Fernando, apenas com nove anos, fizeram reavivar antigas rivalidades políticas que mergulharam novamente o reino de Castela na guerra civil. Esta situação repercutiu-se em Portugal quando D. Dinis, ao tomar em 1297, através do Tratado de Alcanizes, o partido de D. Fernando, se opôs novamente aos interesses do infante D. Afonso que entretanto casara suas filhas em algumas das principais tamílias que se opunham ao novo rei. Apesar da posição conciliatória que o rei português tentou tomar nos acontecimentos então desenrolados, viu-se obrigado, nos inícios de 1299 , a preparar um exército e a marchar novamente sobre o infante. Este recolhera a Portalegre onde o rei já se encontrava a 27 de Abril $\left({ }^{8}\right)$. 0 cerco foi demorado e somente a 25 de Outubro a chancelaria de D. Dinis data as suas cartas de Portalegre $\left({ }^{\circ}\right)$. Pela composição datada de 1 de Julho de 1300 , o infante $\mathrm{D}$. Afonso era obrigado a trocar as suas povoações de Marvão e Portalegre por Ourém e Sintra $\left({ }^{10}\right)$, concretizando-se assim o seu afastamento da fronteira com Castela que tantas preocupações tinha causado já ao seu irmão D. Dinis. Ao mesmo tempo, e certamente a pedido do infante, o rei prometeu não the retirar os seus haveres caso ele abandonasse Portugal $\left({ }^{11}\right)$, o que veio posteriormente a acontecer pois a partir de 1302 vêmo-lo associado à corte castelhana $\left({ }^{12}\right)$.

(') Toda a documentação respeitante a esta composição é citada por Fernando Felix Lopes, «O infante D. Afonso irmão de el-rei D. Dinis», Itinerarium, X, 44, Braga, 1964, p. 204, nota 36, que transcreve também parte da carta de composição de 13 de Dezembro de 1287 nas pp. 203-204.

$\left.{ }^{8}{ }^{8}\right)$ Itinerários Régios Medievais..., p. 15.

( $)$ De 27 de Abril a 16 de Outubro os documentos da sua chancelaria são datados do «arreal sobre Portalegre». Uma única excepção se regista num documento de 14 de Maio datado de Castelo de Vide, Cf. Itinerários Régios Medievais..., pp. 51-52.

${ }^{\left({ }^{10}\right)}$ Fernando Felix Lopes, $O$ infante $D$. Afonso..., p. 210, transcreve parcialmente esta carta de composição.

(11) Idem, ibidem, pp. 210-211.

${ }^{(2)}$ Doc. cit. por Fernando Felix Lopes, $O$ infante D. Afonso..., p. 212. 
O conflito de D. Dinis com seu irmão D. Afonso, iniciado em 1281 e retomado posteriormente em 1287 e 1299, não fez esquecer as tensões anteriores entre o clero e a realeza embora possa ter contribuído para que elas tomassem um novo rumo. Com efeito, datam da altura em que $D$. Dinis se prepara para enfrentar pela primeira vez o irmão as primeiras tentativas, que prosseguirão pelo séc. XIV, de resolução de um diferendo que ocupara largos períodos dos reinados anteriores. As concordatas então celebradas $\left({ }^{13}\right)$, em que se procurava delimitar os campos de intervenção régia e clerical, não impedindo no entanto a continuação do choque entre os bispos portugueses e a corte, diminuiram-lhe todavia o impacto inicial. Ao contrário do que acontecera até Afonso III, a violência nas relações entre clero e realeza será mais conjuntural, não envolvendo nunca uma oposição do clero no seu conjunto às atitudes tomadas pelos reis em determinadas circunstâncias e perante determinados bispos em particular.

Paradigmático desta nova situação é o que se verifica na contenda que opôs D. Dinis ao bispo do Porto, D. Fernando Ramires, nos finais da segunda década do séc. XIV. Os documentos que a referem são uma bula de João XXII, atribuída por D. Rodrigo da Cunha ao segundo ano do seu governo $\left({ }^{14}\right)$ e que acusa o rei de se ter apropriado dos bens do bispo sob o pretexto de que os antecessores deste lhe deviam algum dinheiro e, posteriormente, um documento de Janeiro de 1322 que relata mais circunstancialmente o conflito, referindo que Vasco Pereira, mordomo do rei e irmão do deão do Porto D. Gonçalo Pereira e outros cavaleiros tinham ocupado por mandato régio a jurisdição da cidade, as torres e fortaleza da igreja e também o palácio do bispo $\left({ }^{15}\right)$. Desconhe. ce-se $o$ ano em que os acontecimentos narrados se verificaram mas a análise da documentação contemporânea respeitante a D. Fernando Ramires e ao seu tio D. Frei Estevão, bispo de Lisboa, podem levar-nos, tendo em conta a sua actuação, a tentar uma datação aproximada.

(13) Ver a documentação aduzida por Fernando Felix Lopes, A propósito do Conflito entre a Igreja e Portugal no tempo de D. Dinis, Sep. de «Estudos Teológicos», Actas da III. Semana Portuguesa de Teologia (1963), 1964, pp. 8-13.

(14) Transcrição parcial em D. Rodrigo da Cunha, Catalogo e Historia dos Bispos do Porto, Porto, 1623, 2." parte, pp. 130 e 132. João XXII foi eleito papa a 7 de Agosto de 1316 .

$\left.{ }^{(15}\right)$ Corpus Codicum Latinorum et Portugalensium eorum qui in Archivo Municipali Portucalensi asservantur antiquissimorum, II, Porto, 1917, p. 142. 
A animadversão do rei por D. Fernando Ramires derivou desde logo do modo como este conseguiu o episcopado do Porto em $1314\left({ }^{16}\right)$ e, menos de dois anos depois, concretizou-se no apoio que ele deu às pretensões do concelho do Porto que entretanto tinha entrado em contenda com o bispo $\left.{ }^{17}\right)$. Pela mesma altura ou pouco depois e sem que possamos estabelecer ligações concretas entre ambos os acontecimentos, o rei condenava à morte dois familiares do bispo acusados de um assassinato em Lisboa, junto da corte $\left({ }^{18}\right)$. Finalmente, um terceiro elemento, a contenda entre D. Fernando Ramires e o seu deão D. Gonçalo Pereira $\left({ }^{19}\right)$, terá contribuído para o progressivo isolamento do bispo e preparado assim a acção de força do rei manifestada na ocupação do burgo episcopal. Esta ocupação, tendo em atenção a parte activa que nela tomou Alvaro Pereira, irmão do deão querelado pelo bispo, e o facto da bula referida por Cunha ser do

$\left({ }^{18}\right)$ No seu primeiro manifesto contra o filho, de Julho de 1320, D. Dinis acusa D. Frei Estevão de, quando tratava de assuntos régios na corte pontifícia, ter utilizado o seu dinheiro para conseguir o episcopado de Lisboa para si e do Porto para o seu sobrinho. Vide Fernando Felix Lopes, «O primeiro manifesto de El-Rei D. Dinis contra o Infante D. Afonso seu filho e herdeiro», Itinerarium, XIII, 55 , Braga, 1967, p. 35 .

(ii) A contenda, levada à corte em Maio de 1316 e concluida em 1317, está documentada no Corpus Codicum, I, pp. 55-62.

${ }^{18}$ ) A data de 1319 para este acontecimento, proposta por J. Augusto Ferreira baseado em Frei Francisco Brandão e João Pinto Ribeiro, foi ultimamente posta em causa por Fernando Felix Lopes, com boas razões, pelo facto de não se ajustar à documentação que nos esclarece sobre a actuação dos bispos do Porto e de Lisboa. Com efeito D. Dinis no manifesto de 1320 coloca este acontecimento «a pouco tempo» da transferência de D. Frei Estevão para o bispado de Lisboa e dá-o como causa principal da desavença deste bispo em relação a ele. Ora sabemos por uma bula de João XXII que, pelo menos nos inícios de 1318, este bispo procurava já malquistar o rei com o infante D. Afonso seu filho. Cf. Fernando Felix Lopes, O primeiro manifesto..., pp. 35-36; idem, «Santa Isabel de Portugal. A larga contenda entre el-rei D. Dinis e seu filho D. Afonso», Colectânea de Estudos, IV, 1, Braga, 1953, pp. 29-30.

(1) São aparentemente discordantes as duas notícias que referem esta contenda. Documentos do Arquivo Distrital de Braga, citados por J. Augusto Ferreira, datam-na de Agosto de 1316, mas o Chronicon Coninbricense traslada uma notícia da questão entre ambos dando-a como tendo acontecido nos primeiros meses de 1318 . Deve supor-se que a questão se iniciara em 1316, quando o bispo obrigara o deão a apresentar os títulos dos seus benefícios, e que se arrastara até 1318 altura em que foram nomeados juízes para a resolverem. Cf. J. Augusto Ferreira, Memorias Archeologico-Historicas da Cidade do Porto, I, Braga, 1923, pp. 305-306; Chronicon Conimbricense (ed. A. Pimenta, Fontes Medievais da História de Portugal, I, Lisboa, 1948, pp. 16-17). 
segundo ano do governo de João XXII, ter-se-á verificado entre Março e Julho de 1318. A esta cronologia nos induz tambẻm a parcimonia da documentação que se refere aos bispos de Lisboa e do Porto a partir desta última data $\left({ }^{20}\right)$. Ambos se terão dirigido então, ou no ano seguinte, para Roma não tendo regressado a Portugal.

Neste conflito ecoa já a grave dissenção entre o rei e seu filho D. Afonso que a partir de finais de 1321 se vai transformar em autêntica guerra civil $\left({ }^{21}\right)$. As suas principais causas, e o modo como foi crescendo até aos inícios da década de vinte, são-nos sucessivamente aclarados nos três manifestos que D. Dinis fez publicar contra seu filho entre 1 de Julho de 1320 e 17 de Dezembro de $1321\left({ }^{22}\right)$. A progressiva divisão entre o rei e o herdeiro - no centro da qual estava Afonso Sanches, bastardo de D. Dinis e seu mordomo-mor, acusado de favoritismo régio pelo infante e seus parciais - e que dera origem a vários recontros e assassinatos $\left({ }^{23}\right)$, vai encontrar 0 seu ponto de ruptura no momento em que o infante passa ao ataque, entre fins de Dezembro de 1321 e Fevereiro de 1322, tomando Coimbra, Montemor-o-Velho, Gaia, Feira e o Porto, e dirigindo-se para Guimarães que lhe resiste $\left({ }^{24}\right)$. Após alguns recontros em Coimbra, para onde o infante se dirigira em Março de 1322 ao saber que seu pai cercara a cidade $\left({ }^{25}\right)$, e mediante a intervenção do conde $\mathrm{D}$. Pedro e da rainha $\mathrm{D}$. Isa-

$\left.{ }^{(20}\right)$ A última notícia relativa à presença do bispo D. Frei Estevão em Liśoa é de 9 de Outubro de 1318, altura em que a tensão entre ele e D. Dinis atinge o ponto culminante. Quanto a D. Fernando Ramires já neste ano se deveria ter afastado da sua diocese ou mesmo de Portugal. Cf. F. Felix Lopes, «Das actividades políticas e religiosas de D. Fr. Estevão, Bispo que foi do Porto e de Lisboa», Lusitania Sacra, t. VI, Lisboa, 1962-1963, p. 69; João Pedro Ribeiro, Dissertações Chronologicas e Criticas, V, Lisboa, 1836, p. 183.

${ }^{(21)}$ No manifesto mencionado na nt. $18 \mathrm{D}$. Dinis acusa ambos os bispos de quererem «seu desserviço e seu dano» fomentando a discórdia na família régia.

$\left.{ }^{(22}\right)$ Publicados respectivamente por F. Felix Lopes, in Itinerarium, XIII, 55, Lisboa, 1967, pp. 17-45; F. Felix Lopes, in Colectânea de Estudos, IV, 1, Braga, 1953, pp. 34-40; Livro I de Místicos de Reis. Livro II dos Reis D. Dinis, D. Afonso IV, D. Pedro I, Lisboa, 1947, pp. 135-146.

$\left.{ }_{\left({ }^{2}\right)}\right)$ Ver os documentos citados na nt. anterior.

(2) Chronicon Conimbricense (ed. A. Pimenta, pp. 19-20); Livro de Linhagens do Conde D. Pedro (ed. cit., II/1, p. 130; Crónica dé 1419 (ed. Carlos da Silva Tarouca, Crónica dos Sete Primeiros Reis de Portugal, II, Lisboa, 1952, pp. 112-113); Breve Chronicon Alcobacense (ed. Alex. Herculano, Scriptores, p. 21).

${ }^{(25)}$ Chronicon Conimbricense (ed. cit., p. 20); Livro de Linhagens do Conde D. Pedro (ed. cit., II/1, pp. 130-131); Itinerários Régios Medievais..., p. 86. 
bel, ambos estabelecem as pazes, ratificadas em Leiria nos inícios do mês de Maio $\left({ }^{26}\right)$. $O$ infante, por este acordo, viu acrescentados os seus bens com o senhorio de Coimbra e seu termo e Montemor-o-Velho, e os castelos de Gaia, Feira e Porto, dos quais fez menagem ao rei $\left({ }^{27}\right)$.

Se a posição do infante $D$. Afonso saiu, por então, reforçada, mantinha-se todavia a razão principal que, segundo a documentação contemporânea, levara ao deflagrar da discórdia: Afonso Sanches não tinha sido afastado da corte do monarca $\left({ }^{28}\right)$. Tal facto terá levado a que nos fins de 1323 ou inícios de 1324 o infante afrontasse novamente o pai junto a Lisboa e que os confrontos tivessem continuado em Santarém, aonde o rei se deslocara $\left({ }^{29}\right)$. Um novo tratado de paz, celebrado a 25 de Fevereiro de 1324, previa finalmente o afastamento de Afonso Sanches e um aumento da contia do in-

${ }^{(*)}$ Em Leiria, onde se encontra em 10 de Maio, D. Dinis doa a Estevão da Guarda, um dos seus procuradores na concórdia então efectivada, um moinho; doc. cit. por F. Felix Lopes, «Santa Isabel de Portugal na contenda entre D. Dinis e o filho, 1321-1322», Lusitania Sacra, VIII (1967-1969), Lisboa, 1970, p. 77. Cf. Itinerários Regios Medievais..., p. 86; Crónica de 1419 (ed. cit., p. 116).

${ }^{(77)}$ Crónica de 1344 (ed. in A. de Magalhães Basto, Crónica de Cinco Reis de Portugal, I, Porto, 1945, p. 309); Crónica de 1419 (ed. cit., p. 315).

${ }_{\left({ }^{28}\right)}$ Nos documentos da primeira metade do séc. XIV que se referem a este conflito, duas ordens de razões são sugeridas para justificar a oposição do infante ao rei. Por um lado o favoritismo régio em relação ao seu filho bastardo Afonso Sanches e, por outro lado, a má administração da justiça. Ambas congregaram num mesmo partido ressentimentos de ordem pessoal pelas largas benesses com que o rei foi progressivamente premiando a lealdade do bastardo, e que se poderiam mostrar perigosas no futuro para o herdeiro da coroa, e temores perante a eficácia com que D. Dinis empreendia uma política de centralização que ameaçava os privilégios da nobreza. Não é certamente alheia a este facto a clarificação dos apoios de um e outro partidos ocorrida em 1317, ano em que D. Dinis atacava pela primeira vez a jurisdição senhorial. Quanto a Afonso Sanches, contrariamente ao que é dito na Crónica de 1344 (ed. cit., p. 308), documentos da chancelaria regia posteriores ao acordo de Maio de 1322 mostram-no ainda com assento na Corte. Ver no entanto Luís Filipe Lindley Cintra, Crónica Geral de Espanha de 1344, I, Lisboa, 1951, p. CLVII, nota (81).

$\left({ }^{20}\right)$ Crónica de 1344 (ed. cit., pp. 312-314); Livro de Linhagens do Conde D. Pedro (ed. cit., II/1, p. 131); Crónica de 1419 (ed. cit., pp. 124-126). Segundo os documentos da sua chancelaria D. Dinis está em Lisboa nos últimos meses de 1323. A 17 de Janeiro de 1324 encontra-se em Alvogas, a 22 em Santarém, a 30 em Alverca e a 10 de Fevereiro novamente em Santarém, onde permanece até 3 de Julho. Itinerários Régios Medievais..., pp. 89-90. 
fante, pondo termo às suas reivindicações e ao clima de instabilidade até então vivido $\left({ }^{30}\right)$.

Quando, cerca de um ano depois, o infante D. Afonso subiu ao trono, uma das primeiras medidas que tomou foi fazer reverter para a coroa todos os bens que seu irmão Afonso Sanches, então em Castela, possuia em Portugal $\left({ }^{31}\right)$. Como consequência Afonso Sanches, na primavera e verão de 1325, fez algumas incursões fronteiriças em Trás-os-Montes e no Alto Alentejo tendo numa delas vencido o exército português comandado pelo mestre de Avis D. Gonçalo Vaz, que tinha sido colocado como fronteiro em Ouguela. D. Afonso IV perante este desaire militar invade os domínios do in fante em Castela e apodera-se e destrói, após cerco, a povoação de Codeceira $\left({ }^{32}\right)$. Desconhecem-se novos confrontos o que nos leva a pensar que já em 1326 se teria estabelecido a concórdia entre ambos $\left({ }^{33}\right)$. 0 único documento deste ano que menciona o conflito entre o rei e o infante é uma sentença régia que condena à morte $\mathrm{D}$. João Afonso, tal como Afonso Sanches filho bastardo de D. Dinis, datada de 4 de Julho e dada em Lisboa. Nela D. João Afonso, que no ano anterior havia sido nomeado fronteiro em Portalegre e Arronches, é acusado de conluio com Afonso Sanches e de, em troca de

$\left.{ }^{30}\right)$ Crónica de 1344 (ed. cit., p. 314); Crónica de 1419 (ed. cit., pp. 127-129). Sobre as contradições entre ambas vide nt. 28.

${ }^{(31)}$ Crónica de 1344 (ed. cit., p. 315). As circunstâncias em que este acto se verificou e o seu conteúdo real são desconhecidos. Os documentos publicados referentes às cortes de Evora de $132 \overline{5}$ desautorizam a opinião dos que o ligavam a esta reunião de Cortes. Cf. Cortes Portuguesas. Reinado de D. Afonso IV (1325-1357) (ed. de A. H. Oliveira Marques, Maria Teresa Campos Rodrigues, Nuno José Pizarro Pinto Dias, pp. 13-24).

(32) Crónica de 1344 (ed. cit., pp. 315-316); Crónica de 1419 (ed. cit., pp. 143-144). O Chronicon Conimbricense (ed. cit., p. 18) e o Breve Chronicon Alcobacense (ed. cit., p. 21) são unânimes na atribuição da data de 5 de Outubro de 1325 para a tomada de Codeceira. Neste ano, o último documento da Chancelaria régia é de 2 de Setembro, altura em que o rei está em Lisboa, e aonde regressa somente a 18 de Janeiro de 1326. Cf. Pedro de Azevedo, «A chancelaria de D. Afonso IV», Boletim da segunda classe, VI, Coimbra, 1913 , p. 185.

${ }^{(3)}$ Com efeito, a Crónica de 1344 (ed. cit., p. 316), próxima dos acontecimentos, diz que D. Afonso IV tomada Codeceira e regressado a Portugal "ouve de fazer treguoa com dom A. ${ }^{\circ}$ Sanches e depois por têpo este Rey dom a. ${ }^{\circ}$ cazou sua filha a inffante dona M. ${ }^{a}$ com el Rey de castella em fonte ginaldo». Ora o casamento verifica-se em 1328 e os preparativos são já do ano anterior. Damião Peres data a concórdia de finais de 1326 , não sabemos com que fundamento. Cf. Damião Peres, História de Portugal. Palestras na Emissora Nacional, I, Porto, 1969 , p. 164. 
algumas povoações, se ter comprometido a ajudá-lo com outros nobres caso ele, como aconteceu, invadisse Portalegre ( ${ }^{34}$ ). Cerca de dois anos depois, isto é, por meados de 1328, Afonso Sanches, vassalo de Afonso XI de Castela, morria em Escalona durante o cerco a que o rei submetia esta povoação do infante D. João Manuel que se rebelara contra ele $\left({ }^{35}\right)$.

Por esta altura, nos finais da década de vinte, iniciava-se o longo contencioso que iria opôr o rei Afonso IV aos dois principais potentados eclesiásticos do país: as sés de Braga e do Porto. As razões de ordem pessoal que eventualmente poderão ter desencadeado as contendas - D. Gonçalo Pereira, arcebispo de Braga, tinha sido um dos principais parciais de D. Dinis nas lutas que o opuseram ao então herdeiro D. Afonso, e a eleição pelo Papa de D. Vasco Martins para o bispado do Porto não era do agrado do rei, dado que este procurara fazer eleger D. Miguel Vivas seu clérigo e vedor - juntava-se a política de centralização régia iniciada por D. Afonso III e que, desde inícios do séc. XIV, começava a dar especial atenção ao problema das jurisdições nos senhorios da nobreza e do clero. A quase coincidência cronológica de ambos os conflitos nas suas fases mais violentas, apoia, no entanto, julgamos, uma interpretação que valorize as razões de ordem política em detrimento das razões de ordem pessoal.

A contenda com o arcebispo de Braga terá despoletado quando Afonso IV, na sequência da legislação sobre o tabelionato ${ }^{36}$ ) colocou tabeliões na cidade para tratarem de assuntos régios mormente dos que diziam respeito às igrejas da diocese que eram do seu padroado. $O$ arcebispo perante $O$ que considerou como interferência na sua jurisdição, impediu-os de usarem do seu ofício e excomungou-os. Estes factos datarão já do ano de 1326 atendendo a que o primeiro documento que os refere é uma carta régia de 6 de Fevereiro

(34) Livro das Leis e Posturas, (ed. de Maria Teresa Campos Rodrigues e Nuno Espinosa Gomes da Silva, Lisboa, 1971, pp. 241-244). Notícia, com a mesma datação, no Chronicon Conimbricense (ed. cit., pp. 20-21).

${ }_{\left({ }^{3}\right)}$ Gran Chronica de Alfonso XI (cd. Diego Catalan, I, Madrid, 1977 , p. 435). Sobre a datação do cerco, ocorrido entre meados de Março e princípios de Agosto, ver a documentação publicada por Andrés Gimenéz Soler, Don Juan Manuel. Biografia y estudio critico, Saragoça, 1932 , pp. 563-574.

$\left.{ }^{(30}\right)$ Por uma lei de 1 de Agosto de 1326, Afonso IV colocara os tabeliōes sob a alçada dos seus delegados de justiça locais em casos de queixas por erros de ofício. Cf. Livro das Leis e Posturas (ed. cit., pp. 70-71). 
de 1327, em que Afonso IV encarrega o seu meirinho-mor de Entre Douro e Minho, Vasco Pereira, de repôr a ordem anterior prendendo os rebeldes e insistindo com o arcebispo para que absolvesse os excomungados $\left({ }^{37}\right)$. A 2 de Novembro do mesmo ano, em Coimbra e certamente depois de ter mais uma vez insistido com o rei para que o desagravasse, $o$ arcebispo dá-nos a sua versão do conflito contestando ao mesmo tempo uma afirmação da carta régia de 2 de Fevereiro segundo a qual a assistência de tabeliōes régios em Braga datava já do tempo de D. Dinis $\left({ }^{34}\right)$.

Cerca de um ano depois, no Porto, João Palmciro - procurador do bispo D. Vasco Martins que, eleito e confirmado pelo papa, se mantinha em Avinhão - juntamente com o cabi. do protestavam pelo facto do corregedor de Entre Douro e Minho, João Anes Marvão, se emiscuir na administração da justiça da cidade $\left({ }^{39}\right)$. Esta intrusão do corregedor régio no senhorio cpiscopal, verificada na sequência da eleição e confirmação de D. Vasco Martins como bispo do Porto e consequente recusa da candidatura de D. Miguel Vivas clérigo do rei e seu vedor, mantinha-se ainda nos inícios de 1331 altura de um último instrumento de agravo por parte do Vigário Geral do bispado, Gonçalo Martins $\left({ }^{40}\right)$. Por ele sabemos que as autoridades concelhias do Porto apoiavam a política régia. Com efeito, o novo corregedor de Entre Douro e Minho, Afonso Domingues, obrigara o Vigário Geral a levantar uma excomunhão lançada sobre Gonçalo Afonso, procurador do concelho, pelo facto de este ter apelado à não colaboração dos almotacés da cidade com os da igreja portuense, perante um caso que envolvia dois cidadãos, por considerar que as causas entre laicos pertenciam à jurisdição laica $\left({ }^{41}\right)$.

Com esta posição de força tomada pelo rei, em ambos os casos nos finais da década de vinte, a jurisdição senhorial

${ }^{\left({ }^{37}\right)}$ Documento trasladado no Rerum Memorabilium Eclesiae Bracarensis, II, fl. $25 \mathrm{v}$, cit. e resum. por J. Augusto Ferreira, Fastos Episcopaes da Igreja Primacial de Braga (século III-século XX), II, pp. 131-140. Este conflito é ainda esclarecido por bulas papais de 4 de Março e 21 de Julho do mesmo ano sumariadas pelo Visconde de Santarém, Quadro Elementar, t. IX, 1864, pp. 339-341.

( $\left.{ }^{35}\right)$ J. Augusto Ferreira, Fastos Episcopaes..., pp. 137-133 .

(ia). Publicado no Corpus Codicum..., II, 1917, pp. 168-170.

${ }^{\left({ }^{30}\right)}$ Corpus Codicum..., II, pp. 177-180. Outros documentos que relatam obstrução ao senhorio e justiça episcopais nos anos de 1329 e 1330 in Ibidem, pp. 166-167 e 170 respectivamente. Sobre o sequestro das rendas do bispo provavelmente em fins de 1329 pela sua não comparência ou do seu procurador. na Corte após citação pela carta régia de 9 de Agosto de 1329, Ibidem, pp. 167-168 e 80.

(') Ibidem, p. 177. 
dos bispos de Braga e do Porto abria-se, nos assuntos de ordem temporal que envolviam os laicos, ao controlo exercido pelo rei através dos seus delegados junto das respectivas cidades. Os protestos iniciais dos bispos foram-se atenuando ao longo da década de trinta mas, certamente por iniciativa do rei, e uma vez resolvido o diferendo com Castela em 1340, as ques. tões com ambos os bispados recrudescederam de violência.

Em Braga, no último dia de Fevereiro de 1341, o Vigário Geral, o procurador do Cabido e o juiz do arcebispo protestam contra a ingerência do corregedor de Entre Douro e Minho, Afonso Domingues, na jurisdição episcopal e ameaçam-no com censuras eclesiásticas. Regressado à diocese, o arcebispo D. Gonçalo excomunga-o a 4 de Março. Como medida de retaliação, o corregedor manda notificar o arcebispo para que apresente junto do rei os títulos dos privilégios da igreja bracarense e incita o concelho a revoltar-se contra ele. $\mathrm{O}$ rei, analisadas as cartas apresentadas por D. Gonçalo Pereira, expede a 24 de Agosto do mesmo ano uma carta ao corregedor para que o reintegre na jurisdição da cidade com a condição de que, no capítulo da fiscalização a exercer pelo corregedor, deveria o arcebispo provar não pertencer ao rei tal direito. Vexados com esta ressalva imposta pelo rei, arcebispo e cabido exaram o seu protesto a 30 de Setembro e novamente de posse da jurisdição da cidade excomungam a 5 de Outubro alguns vereadores que entretanto, por incitamento do corregedor, se tinham revoltado ( $\left.{ }^{* 2}\right)$.

No Porto, onde D. Vasco Martins já residia desde 1335, altura em que o rei lhe restituira as rendas que lhe tinha usurpado, o conflito recomeçara já nos finais de 1339 e na sequência da inquirição que o mesmo rei mandara fazer por D. Lopo Fernandes sobre os rendimentos e jurisdição do bispo. A 20 de Dezembro de 1339, pouco mais de três meses após a conclusão da inquirição, já o bispo e o cabido protestavam pela presença do corregedor de Entre Douro e Minho, Vasco Anes, que usava do ofício dentro da cidade contra os privilégios da igreja $\left({ }^{43}\right)$. $\mathrm{Na}$ resposta do corregedor encontramos a argúcia que dois anos depois o rei utiliza contra D. Gonçalo Pereira: que lhe mostrassem os privilégios pelos quais o cor-

('2) A documentação que esclarece este conflito jurisdicional encontra-se no vol. II do Rerum Memorabilium Eclesiae Bracarensis, cartulário da Sé de Braga, organizado nos princípios do séc. XVII, e nas Gavetas do Arquivo Distrital de Braga, e é citado e sumariado por Augusto Ferreira, ob. cit., II, pp. 142-143.

$\left({ }^{4}\right)$ Corpus Codicum..., II, pp. 171-172. 
regedor régio não devia exercer o seu ofício na cidade $\left({ }^{44}\right)$. A situação manteve-se porquanto novos protestos se registaram $\left({ }^{45}\right)$ e, na segunda metade do ano de 1341 , o bispo viu-se na necessidade de abandonar a cidade lançando-lhe o interdito, após um motim popular em que foram mortos um ou dois dos seus vassalos e ele próprio foi obrigado a procurar refúgio numa torre que pertencia à muralha defensiva da igreja enquanto não serenavam os ânimos da população $\left({ }^{46}\right)$.

Certamente para obviar à radicalização de posições que esta revolta do concelho, implicitamente apoiada pelo monarca, manifestara, o papa Clemente VI transferiu D. Vasco para a Sé de Lisboa, em 26 de Agosto de 1342, e nomeou para o Porto o bispo de Astorga D. Pedro Afonso. Todavia as tensões com o rei voltaram logo nos inícios de 1343 quando o corregedor Vasco Anes entrou na cidade e julgou os presos à guarda do Alcaide, após o ter prendido por ele se ter recusado a entregá-los, continuando a exercer o seu ofício mesmo depois das ameaças do Vigário Geral e dos pedidos do bispo para que não se intrometesse na jurisdição que lhe pertencia $\left({ }^{47}\right)$.

A situação agravou-se com o recomeço das hostilidades entre o bispo e o concelho portuense. D. Pedro Afonso, a 24 de Junho do mesmo ano, recusou-se a escolher os juízes da cidade a partir da lista de opçōes que lhe foi apresentada

(") Ibidem, p. 171.

(ii) Instrumentos de agravo de 8 de Fevereiro de 1340 e de \& de Janeiro de 1341, in Ibidem, pp. 172-177.

${ }^{\left({ }^{6}\right)}$ Ibidem, p. 80 . A narração deste motim, feita alguns anos depois por D. Pedro Afonso sucessor de D. Vasco Martins, é muito lúcónica e não permite uma datação exacta do mesmo. Todavia a referência imediatamente anterior à escolha de juizes pelo bispo na festa de S. João - estipulada em concórdias anteriores entre o bispo e o concelho - leva a revolta para a segunda metade de 1341 , após o que, ainda segundo D. Pedro Afonso, se procedeu a uma inquérito que foi enviado ao papa Bento XII.

Precisando um pouco a datação julgamos mesmo que este motim terá sido desencadeado pelo que aconteceu durante a eleição dos novos juizes, e portanto ter-se-á dado nos dias imediatos ao 24 de Junho, sem que todavia possamos precisar as razões de tal acto. A preocupação que D. Pedro Afonso mostra em dizer que D. Vasco Martins nomeara os juízes propostos pelo concelho parece-nos excessiva $c$ vê-sc por outro lado que ele mistura a justificação dos seus actos - «judices non sse vocaberant nec etiam reputabant judices ecclesie nec episcopi sed judices tum Regis..." - com o que acontecera em 1341. Uma hipótese provável é a de que $D$. Vasco Martins tenha de facto nomeado dois juízes mas não dos que constavam na lista proposta pelo concelho, o que por outro lado justificaria as uma ou duas mortes que D. Pedro Afonso diz terem ocorrido durante esse motim.

(ii) Ibidem, p. 81. 
pelo concelho de acordo com a concordata de 29 de Abril de $1325\left({ }^{48}\right)$, tendo em seguida informado o papa do que se passava. A carta dirigida então ao bispo por Clemente VI não ficou registada nos livros que documentam este conflito e as referências que lhe são feitas quer pelo bispo quer pelo rei não ajudam à sua reconstituição dado que ambos a utilizam de acordo com a salvaguarda dos seus interesses na questão. No entanto resulta claro de ambas as interpretações o facto de o papa ter procurado que o conflito fosse resolvido por ambos sem a sua intervenção directa $\left({ }^{49}\right)$.

As diligências efectuadas nos fins de 1343 e ao longo do ano seguinte para resolver o diferendo jurisdicional entre o rei e o bispo não foram coroadas de êxito mas, pelo contrário, conduziram as coisas a uma situação idêntica à que tinha levado D. Vasco Martins, antecessor de D. Pedro Afonso, a abandonar a diocese. Com efeito, goradas as expectativas geradas à volta de um encontro entre ambos em Coimbra $\left({ }^{50}\right) 0$ bispo, uma vez regressado ao Porto e tendo convocado um Sínodo diocesano para Cedofeita, ameaçou o rei com a pena de excomunhão se passados quatro meses ele continuasse a intrometer-se na jurisdição do Porto $\left({ }^{51}\right)$. 0 rei ter-lhe-à respondido à letra, isto é, com novas ameaças, porquanto o bispo, depois de uma assembleia novamente em Cedofeita mas em que estavam presentes delegados régios e o concelho, se pôs em fuga para a Galiza $\left({ }^{52}\right)$.

( ${ }^{48}$ Ibidem, pp. 180-183. Sobre este conflito entre a cidade e o senhorio episcopal, que só indirectamente nos interessa na medida em que esclarece melhor a actuação régia, vide Torquato de Sousa Soares, "A Organização Municipal do Porto nos séculos XII a XIV», in História da Cidade do Porto, dir. por Damião Peres e Antonino Cruz, I, Porto, 1962, pp. 303-371.

(") Ibidem, pp. 106 e 250.

$\left({ }^{50}\right)$ Ibidem, pp. 82-83, 106 e 249-252.

(j1) Ibidem, pp. 106-107 e 250. As censuras eclesiásticas são de 21 de Março de 1345 pelo que o sínodo se terá realizado já em fins de 1344.

(22) Ibidem, pp. 72, 107 e 250-251. Os delegados régios, enviados com o intuito de se conseguir um acordo, eram Mestre Pedro das Leis, o corregedor Martim Pestana e Lourenço Gomes de Abreu. Desconhece-se no concreto o que se terá passado nesta assembleia. Mais uma vez cada parte envolvida apresenta a sua versão dos acontecimentos com acusações, de parte a parte, aos opositores. O facto porém de esta assembleia se ter realizado em Cedofeita, local de onde partira a ameaça de excomunhão do rei, levanta a hipótese, sugerida no texto e confirmada pelos factos subsequentes, de Afonso IV ter pretendido uma espécie de versão laica do sínodo aí realizado mas em que o réu era agora o próprio bispo. 
Aproveitando a ausência do bispo, D. Afonso IV substituiu-o na jurisdição da cidade $\left(^{53}\right)$ e, desprezando as censuras eclesiásticas expedidas da Galiza por D. Pedro Afonso a 21 de Março de $1345\left({ }^{54}\right)$, foi mais longe tentando justificar, na sequência de uma inquirição que mandara efectuar em 1348, a posse do Armazém e casas que construira na cidade $\left({ }^{55}\right)$.

Nos inícios de 1350 , com a apresentação das queixas do bispo perante o papa, o conflito conhece um novo cenário onde a partir de 1353 se começa a desenhar a sua resolução, mas apenas depois de o papa Clemente VI ter censurado o rei pela sua conduta no caso, de este ter sequestrado as rendas do bispo, e de D. Pedro Afonso por sua vez ter excomungado D. Afonso IV e seus partidários $\left.{ }^{(56}\right)$. Em 1354, nomeados, com a anuência de ambas as partes, juízes para resolverem o pleito, este foi sentenciado a 25 de Outubro $\left({ }^{57}\right)$, saldando-se esta sentença numa situação de compromisso que, evitando conflitos posteriores, não terá no entanto agradado de todo às autoridades eclesiásticas. Com efeito desconhece-se a acção do bispo em tempos posteriores. $\mathrm{O}$ interdito por este lançado em Março de 1345 à cidade e diocese parece não ter sido levantado, e o rei continuou posteriormente a substitui-lo na jurisdição da cidade $\left({ }^{38}\right)$.

Se no sul de Portugal a situação era diferente, na medida em que, de formação mais recente, os bispados não tinham nunca conseguido um poderio idêntico aos do norte,

( $\left.{ }^{3}\right)$ Ibidem, pp. 20-21. Os acontecimentos verificados na segunda metade de 1343 e ao longo do ano seguinte, e sua cronologia, têm contornos ainda um tanto indefinidos. Este facto resulta de os documentos que os relatam serem cerca de uma década posteriores e terem sido forjados para justificarem a actuação de ambas as partes perante o papado e perante os juízes que finalmente em 1354 resolveram a contenda.

( $\left.{ }^{34}\right)$ Ibidem, pp. 77 e 107-108. Para a datação da carta de interdito ver o documento do Arquivo Distrital de Braga citado por J. Augusto Ferreira, Memorias Archeologico-Historicas..., I, p. 347.

(تs) Ibidem, I, pp. 20-24; II, pp. 22-23. A inquirição, feita pelo tabelião André Domingues, incidiu sobre os limites do couto episcopal tentando colocar as casas construídas pelo rei fora desse mesmo coutc e portanto da jurisdição do bispo.

${ }^{\left({ }^{3}\right)}$ Ibidem, pp. 256, 73-74 e 251-252. A bula de Clemente VI a Afonso IV, de 17 de Agosto de 1350, é sumariada pelo Visconde de Santarém, ob. cit., IX, p. 355, e por Joaquim dos Santos Abranches, Fontes do Direito Ecclesiastico Portuguez-I: Summa do Bullario Portuguez, Coimbra, 1895, p. 342.

$\left({ }^{57}\right)$ Ibidem, pp. 248-263.

${ }^{(8)}$ Ver os documentos citados por J. Augusio Ferreira, Memorias Archeologico-Historicas..., I, pp. 367-368, e por Torquato de Sousa Soares, ob. cit., p. 345. 
tal facto não impediu por completo a existência de pontos de atrito entre o rei e o bispo de Silves, mormente nos anos trinta e quarenta quando o bispado foi ocupado por Frei Alvaro Pais. Formado em Direito Canónico na Universidade de Bolonha, cioso dos privilégios e prerrogativas eclesiásticas e instigador de profundas reformas na sociedade laica e eclesiástica, Alvaro Pais viu-se envolvido em conflitos com o clero da sua diocese, com os concelhos do Algarve, com a Ordem de Santiago e também com o próprio rei $\left(^{59}\right)$.

A oposição do bispo ao monarca data de 1336, após Afonso IV ter declarado guerra a Afonso XI de Castela pelo facto de este tentar evitar a consumação do casamento de D. Constança, filha do magnate castelhano D. João Manuel, com o herdeiro português D. Pedro. Nas duas cartas que ainda nesse ano escreve ao rei, Alvaro Pais insurge-se contra a guerra então iniciada considerando-a apenas fruto do desejo de vã glória do monarca português, porquanto o casamento entre D. Constança e D. Pedro, sua causa, não se podia realizar propter duplicis honestatis iustitie impedimentum, e verbera o procedimeno do rei ao exigir ao clero contribuições especiais para as despesas da guerra, acusando-o ao mesmo tempo de lhe ter embargado os bens e de não ter procedido do mesmo modo com outros clérigos $\left({ }^{80}\right)$. A violência das suas palavras a que terá respondido provavelmente o rei com o embargo de que se queixa o bispo na sua segunda carta aconselharam-no talvez a deixar Portugal onde o encontramos novamente apenas nos inícios da década de quarenta $\left({ }^{61}\right)$.

Os conflitos com o rei renovaram-se no entanto nos finais da década de quarenta. Por uma carta régia de 31 de

$\left.{ }^{(50}\right)$ Uma contribuição mais recente para a biografia deste personagem encontra-se em António Domingues de Sousa Costa, Estudos sobre Alvaro Pais, Lisboa, 1966.

${ }^{(0)}$ Ambas as cartas foram publicadas por António Domingues Sousa Costa, ob. cit., pp. 146-152. Os agravos feitos ao clero constam também nas duas cartas que o papa Bento XX escreveu a Afonso IV em 30-12-1337 e 8-6-1338. Idem, ibidem, pp. 99-101 e 104-105.

( $\left.{ }^{01}\right)$ Em 1337 Álvaro Pais já se encontra na Galiza onde assiste a um sínodo reunido em Santiago de Compostela e aí se mantém ainda em 1340 data em que revê pela segunda vez a sua obra De Statu et Planctu Ecclesiae. Cf. D. Rodrigo da Cunha, Historia Ecclesiastica dos Arcebispos de Braga, II, Braga, 1635, p. 239; João Morais Barbosa, $O$ «De Statu et Planctu Ecclesiae». Estudo crítico, Lisboa, 1982, p. 157, nt. 3. Nos acrescentos do seu De Statu, resultantes da revisão de 1340, ecoam já, directa ou indirectamente as dissenções que teve com o clero e monarcas portugueses. Num deles, lembrando-se porventura também do seu caso particular, refere que os bispos em vez do respeito recebiam, por parte dos monarcas portugueses, a morte, a prisão e o degredo. João Morais Barbosa, ob. cit., pp. 73-100 e 162, nt. 72. 
Maio de 1347 o rei julgava uma contenda havida entre o bispo e a igreja de Silves por um lado e os concelhos do Algarve por outro, contenda esta que tinha subido já ao arcebispo de Sevilha $\left({ }^{62}\right)$. Nos vinte e um agravos apresentados pelo procurador dos concelhos algarvios sobressaem os relativos à definição das jurisdições laica e eclesiástica, tendo sido apresentados alguns casos concretos em que o bispo e os seus oficiais se intrometiam em assuntos do foro civil ou impediam a actuação do alcaide, juízes ou outros funcionários, ameaçando e excomungando quem se lhes opunha. $\mathbf{O}$ clima de tensão entre o bispo, por um lado, e o rei e concelhos por outro, patente nas queixas apresentadas, irá explodir nos dois anos seguintes de forma violenta sem que possamos no entanto estabelecer com precisão a cronologia dos acontecimentos verificados, as razões que os motivaram e o carácter da intervenção régia. 0 que se passou conhecêmo-lo através de uma carta de 27 de Setembro de 1349 que Alvaro Pais, refugiado em Sevilha, dirigiu ao papa Clemente VI refutando a versão dos acontecimentos que lhe fora apresentada por D. Lourenço Vasques, mestre da Ordem de Santiago e um dos intervenientes mais activos nas perseguições então movidas contra ele $\left({ }^{03}\right)$. Aí Alvaro Pais refere também a actuação de Lourenço Calado, corregedor do Algarve, e justifica a dado passo o seu desterro dizendo que fora banido do bispado pelo Mestre de Santiago e pelo Cabido com o apoio do Rei, por defender a jurisdição da Igreja $\left({ }^{64}\right)$. Pouco depois o bispo morria em Sevilha.

Quando em 1354 se apaziguava o diferendo que opusera Afonso IV ao clero português, representado então pelo bispo do Porto D. Pedro Afonso, a atenção do monarca dirigia-se já para a crise política que se avolumava em Castela e ameaçava estender-se a Portugal. Com efeito, pretendendo seguir a política centralizadora de seu pai, D. Pedro de Castela agregara pouco a pouco contra si alguns dos principais magnates do reino. Entre estes, e para além dos seus irmãos bastardos, D. Henrique e D. Fadrique, mestre de Santiago, encontramos desde 1354 D. João Afonso de Albuquerque, de ascendência portuguesa porque filho de Afonso Sanches, Alvaro Pires de

( ${ }^{(2)}$ Publicado por João Pedro Ribeiro, Dissertações Chronologicas e Criticas, t. III, p. II, Lisboa, 1813, pp. 171-183.

${ }^{(8)}$ ) A carta de 27 de Setembro de 1349 foi publicada em tradução portuguesa, por Jorge Cardoso, Agiologio Lusitano, I, Lisboa, 1652, pp. 252-253.

(क) Idem, ibidem, p. 253. 
Castro, refugiado em Portugal, e seu irmão D. Fernando de Castro $\left({ }^{65}\right)$. A ligação de Inês de Castro, irmã de ambos, ao infante D. Pedro $\left({ }^{68}\right)$ e o facto de, através de Alvaro Pires de Castro, lhe ter sido proposto em 1354 que se candidatasse ao trono castelhano, tornavam-se um perigo para a neutralidade que Afonso IV procurara manter até então nestas lutas, ameaçando transformar o território português num campo de operações dos opositores do rei castelhano ${ }^{67}$ ). E neste contexto que logo a 7 de Janeiro de 1355 Afonso IV manda degolar Inês de Castro em Coimbra $\left({ }^{68}\right)$.

$O$ infante $D$. Pedro, reunindo um exército que incluia parciais dos Castros, assola nos meses seguintes o norte do país, praticando devastações nas terras do rei e dos seus conselheiros, que culpava também pela morte de Inês de Castro e, descendo para Sul, tenta tomar o Porto defendido pelo prior do Hospital D. Alvaro Gonçalves Pereira $\left.{ }^{(8 \theta}\right)$. A cidade oferece-lhe resistência e com a aproximação de D. Afonso IV, vindo de Guimarães onde tomara conhecimento do cerco, o infante afasta-se para o interior. Sob a acção da rainha D. Beatriz e do arcebispo de Braga D. Guilherme, um tratado de paz é estabelecido a 5 de Agosto do mesmo ano pelo infante no Marco de Canavezes e ratificado pelo rei a

(5) Pedro Lopez de Ayala, Cronicas de los Reyes de Castilha (cd. de D. Eugenio de Llaguno, Madrid, 1779, I, pp. 123-125, 134-135).

$\left({ }^{* 0}\right)$ O conhecimento concreto do tipo de relações existentes nesta altura entre o infante $D$. Pedro e D. Inês de Castro ajudaria, sem dúvida, a esclarecer melhor os acontecimentos posteriores. Apesar dos instrumentos de 12 e 18 de Junho de 1360 em que D. Pedro procura provar que casara com Inês de Castro nos primeiros anos da década de cinquenta, os documentos contemporâneos são contraditórios, e a própria posição de Fernão Lopes sobre o assunto, mesmo tendo em conta a sua preocupação em acumular documentos e indícios que negassem o casamento entre ambos, é equívoca. Somente um estudo aprofundado e crítico de toda a documentação existente, poderá trazer dados seguros sobre esta questão. Sobre a posição de Fernão Lopes vide Salvador Dias Arnaut, «A crise nacional dos fins do séc. XIV», Biblos, XXXV, Coimbra, 1959, pp. 95-96.

${ }^{\left({ }^{67}\right)}$ Pedro Lopez de Ayala, ob. cit., p. 126.

( $\left.{ }^{85}\right)$ Cf. Chronicon Conimbricense (ed. António Cruz, Anais, Crónicas e Memórias Avulsas de Santa Cruz de Coimbra, Porto, 1968, p. 79); Breve Chronicon Alcobacense (ed. cit., p. 22).

${ }^{\left({ }^{89}\right)}$ Livro de Linhagens do Conde D. Pedro (ed. cit., II/1, p. 241); Crónica de 1419 (ed. cit., pp. 368-369). O arcebispo de Braga D. Gonçalo Pereira nomeado por esta crónica como defensor do Porto havia morrido já há cerca de seis anos. Cf. J. Augusto Ferreira, Fastos Episcopaes..., II, pp. 159-160. 
14 de Agosto seguinte em Guimarães $\left({ }^{70}\right)$. Nele o infante prometia, entre outras coisas, perdoar aos nobres que considerava culpados na morte de Inês de Castro e utilizar o poder de fazer justiça apenas nos casos e da maneira que lhe tinha sido outorgado $\left({ }^{71}\right)$.

Com este tratado a situação não terá serenado por completo porquanto a 16 de Janeiro seguinte, em Braga, o rei perdoava aos vassalos do infante o que tinham feito "contra el e contra o seu servyço" após a composição de Agosto anterior e o infante era agraciado com mais algumas benesses $\left({ }^{i 2}\right)$. Com estas novas mercês o infante aquietou-se esperando certamente melhor oportunidade para se vingar dos conselheiros que tinham acompanhado o rei a Coimbra aquan. do da morte de Inês de Castro $\left({ }^{i 3}\right)$.

Nos cerca de dez anos de governo de $\mathrm{D}$. Pedro não encontramos quaisquer documentos que confirmem a continuidade do tipo de conflitos que temos vindo a assinalar. No entanto, uma fonte posterior de carácter narrativo dá conta da existência provável de desentendimentos entre o rei e o arcebispo de Braga D. João de Cardaillac. Com efeito, na segunda metade de 1377 D. Lourenço Vicente, então arcebispo de Braga, nas acusações que formulou contra Vasco Domingues, chantre da mesma Sé e um dos visitadores apostólicos que o privaram do governo da diocese, refere-se à prisão de D. João de Cardaillac pelo rei em Coimbra e posteriormente em Leiria por intrigas do referido chantre $\left({ }^{74}\right)$. Tendo em conta a documentação que nos esclarece sobre a trajectória do arcebispo, a sua prisão somente se poderia ter verificado

(io) O instrumento da composição entre ambos está publicado no Livro I de Místicas de Reis. Livro II dos Reis D. Dinis D. Afonso IV D. Pedro I, Lisboa, 1947, pp. 201-212, e dá alguns esclarecimentos acerca da actuação do infante no norte do país na primeira metade de 1355 .

('1) Ibidem, pp. 206-209.

( $\left.{ }^{72}\right)$ Ibidem, pp. 213-221.

${ }^{(3)} \mathrm{O}$ que veio a acontecer em 1360 depois de um acordo celebrado com D. Pedro de Castela. De Pero Coelho, Alvaro Gonçalves e Diogo Lopes Pacheco, apenas o último conseguiu escapar à troca de exilados políticos então concretizada entre ambos os monarcas. Vide Pedro Lopez de Ayala, ob. cit., pp. 310-311.

$\left({ }^{74}\right)$ Rerum Memorabilium, II, 49V. e segs.; cit. por D. Rodrigo da Cunha, Historia Ecclesiastica dos Arcebispo de Braga, II, Braga, 1635, pp. 191 e 197-198; e por J. Augusto Ferreira, Fastos Episcopaes..., II, p. 173. 
por volta de Setembro de $1366\left({ }^{75}\right)$, embora se desconheçam as razões de tal facto $\left({ }^{78}\right)$.

(i5) Vide J. Augusto Ferreira, Fastos Episcopaes..., II, pp. 170-173. Nesse mesmo período a Chancelaria de $D$. Pedro dá-o com assento na Estremadura e Alto Alentejo registando documentos de Leiria a 13,19 e 27 de Outubro, e 9 e 12 de Novembro. Cf. Maria Teresa Campos Rodrigues, «O Itinerário de D. Pedro I - 1357-1367», Ocidente, vol. LXXXII, n. ${ }^{\circ} 408$, Lisboa, 1972, pp. 175-176.

${ }^{(70)}$ As motivaçôes de ordem política por vezes invocadas - D. João de Cardaillac era partidário de D. Henrique de Trastamara - colidem com a posição assumida pelo rei português neste ano de 1366 perante a viragem verificada em Castela. Com efeito para além de ter procurado furtar-se a ajudar o rei destronado, D. Pedro de Castela, o rei português assinou um tratado de paz com o usurpador Henrique de Trastamara. Pierre David tendo em conta este contexto, põe mesmo a hipótese de a prisão do arcebispo referida por D. Lourenço Vicente resultar de uma confusão com o aprisionamento do mesmo arcebispo por D. Pedro de Castela, após a sua reconquista do poder na sequência da batalha de Najera, de Abril de 1367 , em que vencera $D$. Henrique. Por outro lado o facto de o acusado Vasco Domingues, em circunstâncias diversas, ter também brigado com o antecessor e com o sucessor de João de Cardaillac leva-nos a pensar que a prisão do arcebispo, a ser de facto confirmada, se deveria mais a motivos de ordem religiosa e local. Cf. Damião Peres (dir.), História de Portugal, II, Barcelos, 1929, pp. 322-324; Pierre David, Français du midi dans les Evêchés Portugais (1279$-1390)$, Lisboa, 1944, p. 5. 
(Página deixada propositadamente em branco.) 
3.

Começando o reinado de D. Fernando em 1367, constatamos logo nos anos de 1371 a 1373 a eclosão de revoltas ou "uniões» populares $\left({ }^{1}\right)$ envolvendo importantes vilas e cidades do Reino: Lisboa, Alenquer, Santarém, Abrantes, Tomar e Leiria $\left({ }^{2}\right)$.

Através da sua Crónica de D. Fernando $\left({ }^{3}\right)$, Fernão Lopes tem sido utilizado como fonte informativa prioritária para os estudos destes acontecimentos. De acordo com o cro-

(') Parece não haver grandes dúvidas acerca desta datação. A hipótese (provável) de Lisboa ter funcionado como detonador das movimentaçōes induz-nos a situar o início dos acontecimentos à entrada do segundo semestre de 1371 pois, de acordo com o itinerário régio (vide Maria Teresa Campos Rodrigues, «Itinerário de D. Fernando, 1367-1383», Bracara Augusta, vol. XXXII, 1978) o rei aí se encontrava nesta altura, ao contrário do que se verificará entre Outubro de 1371 e Maio de 1373! Quanto ao seu desenvolvimento nos anos de 1372 e 1373 , o principal argumento consiste na proliferação de cartas régias de confiscação de bens (por alegado envolvimento em «motins contra o serviço real») a indivíduos das localidades em causa, datadas do ano de 1373. Aliás, o próprio teor de alguns artigos das cortes celebradas em Leiria logo no mês de Novembro de 1372 vem corroborar largamente esta ideia (vide nt. 3). Cf. docs. citados em: Maria José Pimenta Ferro Tavares, "A revolta dos Mesteirais de 1383», Actas das III Jornadas Arqueológicas, vol. I, 1977, pp. 373-374; Idem, "A nobreza no reinado de D. Fernando", Revista de História Económica e Social, n. ${ }^{\circ}$ 12, Julho-Dezembro de 1983, pp. 54-55; Monarquia Lusitana, t. VIII, 1727, livr. XXII, pp. 185 e 186; Salvador Dias Arnaut, $A$ Crise Nacional dos fins do século XIV, Coimbra, 1960, p. 14, nt. 1 (transcr. parc.).

(') Não sendo expressamente mencionada por Fernão Lopes («e nom soomente em Lixboa, mas em Santarem e em Alanquer e em Tomar e Avrantes e outros logares do reino» - Crónica de D. Fernando, Lisboa, 1975, cap. LXI) a cidade de Leiria viu-se, contudo, também envolvida nestes motins, como o comprova documentação indicada na nota anterior.

(3) Designadamente nos caps. LX, LXI e LXIII. 
nista, a motivação de tais revoltas encontrar-se-ia na oposição popular ao projectado casamento do monarca com D. Leonor Teles, mulher do fidalgo João Lourenço da Cunha $\left({ }^{4}\right)$, que acabaria por consumar-se no mosteiro de Leça, a 16 de Maio de 1372 . Hoje, contudo, parece razoável alargar consideravelmente o âmbito interpretativo daquelas "uniões» $\left({ }^{5}\right)$.

Em todo o caso parece não oferecer grandes dúvidas o carácter violento que assumiu a resposta régia a tais levantamentos. E o que se conclui, por exemplo, das cortes de Leiria de 1372, nas quais os povos solicitam a El-Rei o per. dão para os incriminados naqueles acontecimentos $\left({ }^{6}\right)$.

Contudo, tal violência não terá tido o condão de travar em absoluto a eclosão de novas movimentações, reflexo evidente da profunda instabilidade social em que mergulhava $o$ Reino à entrada do último quartel do século XIV. A prova disso encontra-se em cartas régias de confiscação de bens datadas de 1374,1375 e 1379 , reveladoras de outras tantas revoltas em Portel, Montemor-o-Velho e Tomar, respectivamente $\left({ }^{7}\right)$.

Algo de confluente acontece, aliás, em relação a Sousel $\left({ }^{8}\right)$, povoação do Alto Alentejo, que se envolve, nas proximidades do ano 1382, num grave conflito com D. Fernando, ao amotinar-se, recusando cumprir um mandato régio e assas-

(') Opinião perfilhada, entre outros, por Fr. Manuel dos Santos, Monarquia Lusitana, VIII, pp. 144-146 e por S. D. Arnaut, ob. cit., espec. pp. 13-14.

$\left({ }^{3}\right)$ E o que deve fazer-se ponderando factores de natureza diversa como, por exemplo, a evolução (negativa) da conjuntura financeira (com realce para as revalorizações monetárias ocorridas precisamente nos anos de 1371 e 1372) ou ainda a persistência das desastrosas guerras fernandinas contra Castela. Sobre estes aspectos, devem ver-se os trabalhos de Maria José P. F. Tavares, A revolta..., pp. 360-363, e A Nobreza..., espec. pp. 52-55.

$\left({ }^{8}\right)$ Cf. doc. in Maria José P. F. Tavares, A Nobreza..., p. 54. A violenta repressão régia das revoltas (execuções, decepamento de membros, etc.) é também confirmada por Idem, Ibidem, p. 54, nt. 62, e pelo próprio Fernão Lopes, ob. cit., cap. LXI.

( ) Cf. docs. citados por: Maria José P. F. Tavares, $A$ revolta..., p. 364 e nts. 63,64 e 65, e S. D. Arnaut, ob. cit., pp. 14-15, nt. 1 (transcr. parc.). As motivações de tais revoltas serão, com toda a probabilidade, próximas das apontadas para as «uniões» de 1371-1373, anteriormente referidas. Registe-se ainda a possibilidade de alastramento deste tipo de motins a outras localidades do Reino, em condições não totalmente esclarecidas. $\hbar$ o caso, por exemplo, de Valença (vide Maria José P. F. Tavares, $A$ revolta.., p. 364, nt. 67).

( $)$ Conflito estudado por Armando Luís de Carvalho Homem, "Nótula sobre um levantamento popular nas vésperas do Interregno», Bracara Augusta, vol. XXXII, 1978, pp. 229-245. Cf. documentação aduzida. 
sinando, inclusive, o enviado do monarca (Gonçalo Eanes de Alter, juiz em Estremoz) encarregado de cumprir a referida determinação, conforme claramente o denuncia a carta régia passada em Évora, a 10 de Abril de $1382\left({ }^{\circ}\right)$. Aqui, a "união» popular ter-se-à polarizado em torno da oposição à estratégia real de apropriação de terras concelhias (no caso, aplicada às herdades de Sousel e seu termo). Não conseguindo fazer vingar as suas reivindicações, os moradores de Sousel viram-se, entretanto, objecto do perdão do monarca $\left({ }^{10}\right)$ e terão, muito provavelmente, condicionado a doação feita, em 1382, a Pero Rodrigues da Fonseca de parte dos direitos régios em discussão $\left.{ }^{(11}\right)$.

A existência (se não mesmo a predominância), no reinado de D. Fernando, de conflitos envolvendo a participação directa de camadas populares (e que terão, como veremos, particular alcance político após a morte do monarca) não exclui, entretanto, a possibilidade de afrontamentos violentos, ainda que episódicos, entre a realeza e o clero.

E, concretamente, o que se verifica (de uma forma mais aguda) no ano de 1377, entre o arcebispo de Braga, D. Lourenço Vicente, e o rei, ao qual se encontram momentaneamente aliadas diversas figuras da nobreza minhota e do próprio clero do cabido de Braga.

Nomeado arcebispo de Braga em 19 de Dezembro de 1373, e sagrado nessa mesma qualidade a 14 de Janeiro de 1374 , D. Lourenço obteve automaticamente, da parte do rei, o cumprimento da promessa de restituição ao Arcebispado de Braga do "livre império da cidade» $\left.{ }^{12}\right)$. Esta situação ter-

$\left(^{\circ}\right.$ Cf. doc. in Idem, Ibidem, p. 240 (doc. n. ${ }^{\circ}$ 5). Os termos desta carta régia justificam, aliás, a localização que fizemos do conflito ( nas proximidades do ano de 1382 )), precisando um pouco mais a sugestão de Carvalho Homem, que se limitou a balizá-lo entre 1375 e 1382 (vide ob. cit., p. 230):

«.... Porem, mandamos a todallas outras nossas justiças que nom prendam aos ssobre dictos moradores de Sousell, nem lhii façam outro desagisado nem huum quanto he por a dicta rrazom, e que se alguuns por ello ssom pressos que os soltedes logo....

( $\left.{ }^{10}\right)$ Concedido na mesma carta régia citada na nt. anterior.

(1) Cf. doc. in Idem, Ibidem, p. 241 (doc. n. ${ }^{\circ}$ 6).

(12) Consagrado por carta régia passada em Atouguia, a 22 de Agosto de 1374. (Cf. doc. in D. Rodrigo da Cunha, História Eclesiástica de Braga, 1635, t. II, pp. 194-195); por seu intermédio, o monarca português dava cumprimento à carta régia de Santarém, 27 de Março de 1373 (Cf. doc. in Monarquia Lusitana, VIII, p. 202), segundo a qual prometia restituir a soberania eclesiástica ao Arcebispado de Braga se o Papa Gregório XI acedesse em prover como Arcebispo daquela cidade D. Lourenço Vicente, Vedor da Fazenda Real e recentemente eleito bispo do Porto. 
-lhe-à permitido iniciar uma acção reformadora com alguma profundidade, natural numa Sé que vivera mais de dois anos em situação de vacatura $\left({ }^{13}\right)$ e cujo passado recente (designadamente no período correspondente ao bispado de D. João de Cardaillac) revelara a existência de graves problemas $\left({ }^{14}\right)$. Só a intensidade dessa acção reformadora $\left({ }^{15}\right)$ poderá explicar que num período curto de três anos (1374-1377) se tenham despoletado tão grandes descontentamentos entre a nobreza local e mesmo entre gente ligada ao cabido bracarense para com o novo Arcebispo, que acabaram por traduzir-se em graves queixas ao rei D. Fernando $\left({ }^{16}\right)$, o qual, curiosamente $\left({ }^{17}\right)$, rapidamente as subscreveu e se encarregou de as transmitir ao Papa Gregório XI, acompanhadas do pedido de demissão imediata e punição do Arcebispo $\left.{ }^{(18}\right)$. Uma comissão de Visitadores do Arcebispado e da pessoa do Arcebispo nomeada pelo Sumo Pontífice penetrou, em Agosto de 1377, em terras de Braga, acompanhada do Meirinho-mór d'Entre Douro e Minho, Lopo Gomes de Lira, e de gente armada $\left({ }^{19}\right)$. De nada valeram os protestos de $D$. Lourenço que, considerado culpado, viu os seus bens e os da Mitra confiscados, a cidade ocupada militarmente pelo Meirinho-mór e a sua própria integridade física ameaçada $\left({ }^{20}\right)$. Refugiando-se em Roma junto de Urbano VI (que substituira, no trono de S. Pedro, Gregório XI, por morte deste, em 27 de Março de 1378), o Arcebispo obtém um novo juiz da causa, D. João, Cardeal de Sabina, que acabará por proferir, em 14 de Fevereiro de 1379, a sentença definitiva $\left({ }^{21}\right)$. Regressado, vitorioso, a Braga, D. Lou-

$\left({ }^{13}\right)$ Com efeito, entre 18 de Novembro de 1371 e Janeiro de 1374, o Arcebispado de Braga encontrou-se em situação de «sede vacante». (Vide D. Rodrigo da Cunha, ob. cit., p. 193, e J. Augusto Ferreira, Fastos Episcopaes da Igreja Primacial de Braga, 1931, t. II, p. 179 , nt. 1).

(14) Vide, neste trabalho, a parte relativa aos conflitos com o Arcebispado de Braga ocorridos no reinado de D. Pedro I.

${ }^{(15)}$ De que o próprio arcebispo dará conta no processo que será (como veremos adiante) instaurado pelo papa Urbano VI. Cf. doc. in D. Rodrigo da Cunha, ob. cit., pp. 195 e 196.

${ }_{\left({ }^{18}\right)}$ Cf. doc. in D. Rodrigo da Cunha, ob. cit., p. 197.

(17) Lembremos que (vide nt. 12) o rei fora o principal responsável pela elevação de $D$. Lourenço Vicente ao cargo de arcebispo de Braga. Agora, no contexto desencadeado, D. Fernando parece aproveitar-se da situação para tirar vantagens sobre o Arcebispado de Braga, cuja nova orientação parecia começar também a incomodá-lo!

$\left({ }^{18}\right)$ Vide D. Rodrigo da Cunha, ob. cit., p. 197, e J. A. Ferreira, ob. cit., p. 183.

$\left({ }^{10}\right)$ Vide Idem, Ibidem.

$\left({ }^{20}\right)$ Vide Idem, Ibidem, p. 198 e p. 184, respectivamente.

${ }^{21}$ Cf. doc. in D. Rodrigo da Cunha, ob. cit., pp. 198-199. 
renço Vicente promove a divulgação da sentença em sínodo diocesano $\left({ }^{22}\right)$, mas terá ainda de esperar até finais de 1382 para conseguir obter de $D$. Fernando a restituição da soberania eclesiástica sobre Braga e seus coutos $\left({ }^{23}\right)$.

A medida que nos aproximamos do final do reinado de D. Fernando, começamos a detectar a multiplicação de movimentações políticas centradas junto da própria corte, certamente resultantes não só da situação de instabilidade em que se desenvolvera quase todo o reinado deste monarca (e que os conflitos atrás enunciados - designadamente as "uniões» populares de 1371 a 1379 - parecem comprovar), como também das clivagens internas no seio da nobreza muito provavelmente operadas após o casamento de D. Fernando com D. Leonor Teles $\left({ }^{24}\right)$. Será o caso, concretamente, das tentativas de assassínio do rei (por envenenamento) promovidas por João Lourenço da Cunha e por Diogo Lopes Pacheco (duas importantes figuras da nobreza do Reino) e conhecidas através de cartas régias de 1379 e $1380\left({ }^{25}\right)$. Situação que, afinal, tenderá a agudizar-se com o pressentimento da morte próxima do monarca sem descendência sucessória legítima e numa conjuntura política externa altamente periclitante $\left({ }^{28}\right)$.

$\left.{ }^{(22}\right)$ Que se terá realizado, de acordo com D. Rodrigo da Cunha, ob. cit., p. 199, a 16 de Novembro de 1381 , ou, segundo J. A. Ferreira, ob. cit., p. 185 , nt. 1 , em Setembro de 1379 (para o que aduz, diga-se, boas razōes). António Garcia y Garcia (dir.), in Synodicon Hispanum, II, Portugal, Madrid, 1982 , pp. 54 e 57 , refere as duas datas, mantendo-se, portanto, a dúvida.

${ }_{(23)}$ Trata-se da carta régia passada em Sanzes a 7 de Setembro de 1382. Cf. doc. in $\mathrm{D}$. Rodrigo da Cunha, ob. cit., pp. 199-200. Registe-se, entretanto, que $D$. Rodrigo da Cunha (que o transcreve do Rerum Memorabilium, II, fl. 38v.) apresenta o documento com a data de 7 de Outubro de 1382, o que não corresponde ao original, conforme refere J. A. Ferreira, ob. cit., p. 185, nt. 3. De resto, o itinerário régio (vide Maria Teresa C. Rodrigues, ob. cit., pp. 222 e 223) confirma plenamente a argumentação de J. A. Ferreira: em 7 de Setembro de 1382 o monarca encontra-se de facto em Sanzes (ou Saazes) enquanto que um mês depois estará em Lisboa (e na Amoreira).

(24) Hipótese de trabalho que um melhor conhecimento deste reinado vem progressivamente confirmando.

$\left.{ }^{25}\right)$ Cf. docs. in Monarquia Lusitana, VIII, p. 151, e Maria José P F. Tavares, $A$ revolta..., p. 364, nt. 72 e $A$ nobreza..., p. 56, nt. 66; a confiscação de bens a Diogo Lopes Pacheco é justificada nestes termos: «....e mais o que peyor he nom tam solamente em nossa presença se armou com filhos e outras gentes pera nos guerrear como dicto he, mais ainda trautou e pos em obra pera nos dar peçonha per que perdesemos vida se acabar pudera».

(20) Pensamos que é neste enquadramento genérico que melhor poderemos compreender alguns acontecimentos que, sem que saibamos terem ficado registados em qualquer documento coevo alguma vez 
Com efeito, a morte de D. Fernando, ocorrida em Lisboa a 22 de Outubro de $1383\left({ }^{27}\right)$, abre um período explosivo na história da sociedade medieval portuguesa, no qual as tensões acumuladas ao longo das décadas anteriores encontram terreno propício à sua conversão em movimentos contestatários ainda algo híbridos e debilmente organizados, mas já dispostos a intervir na discussão do problema do poder $\left({ }^{28}\right)$.

E assim que, logo após a noite do falecimento do monarca e durante o lapso de tempo que a separa da celebração (ozorrida um mês depois, em Lisboa $\left({ }^{29}\right)$ ) das respectivas

impresso, são, contudo, largamente relatados por Fernão Lopes na sua Crónica de D. Fernando, e posteriormente aproveitados por diversos outros autores. Referimo-nos, designadamente, ao assassínio de D. Maria Teles (Irmã da rainha) pelo lntante $D$. João (filho de D. Pedro I e de D. Inês de Castro), provavelmente ocorrido em Coimbra, em Junho ou Julho de 1379 (vide F. Lopes, ob. cit., caps. C a CV, e S. D. Arnaut, ob. cit., espec. pp. 130-140 e cf. doc. aduzida) e à prisão do Mestre de Avis e do importante fidalgo e valido do rei, Gonçalo Vasques de Azevedo, verificada provavelmente em 1382 e motivada por razóes que devem extravasar largamente a argumentação apresentada pelo cronista e repetida por outros autores (vide F. Lopes, ob. cit., caps. CXXXIX a CXLVII, e Monarquia Lusitana, VIII, p. 382 e ss.). A própria partida do infante D. João para Castela em Outubro de 1380 (vide S. D. Arnaut, ob. cit., p. 146) encontrar-se-á também dentro desta mesma linha explicativa.

${ }_{\left({ }^{27}\right)}$ Vide F. Lopes, ob. cit., cap. CLXXII.

(28) Pensamos que a conjuntura de finais de 83 (cuja especificidade política deriva, em boa parte, da existência do problema da sucessão e dos termos do acordo de Salvaterra de Magos que a regulamentava - cf. doc. in S. D. Arnaut, ob. cit., p. 357) se caracteriza sobretudo por ter conseguido promover a aglutinação de focos de descontentamento de origem diversa (designadamente do meio popular e de certos sectores da nobreza) amadurecidos ao longo do reinado de D. Fernando. É esta fusão, naturalmente operada de uma forma progressiva e talvez nem sequer premeditada, que dará conteúdo e forma a muitos dos movimentos de contestação que adiante referiremos.

Esclareça-se, entretanto, que abdicaremos aqui - dada a natureza deste trabalho - de uma tentativa de interpretação sistemática destes movimentos. Importantes contributos foram, de resto, já avançados por outros autores (em especial Marcello Caetano, Salvador Arnaut e Maria José P. Ferro), designadamente quanto a um eventual ordenamento "partidário» das forças em confronto e suas ligações internas e externas, quanto à relevância da componente popular (mesteiral e/ou «burguesa») na evolução dos acontecimentos ou quanto à natureza e ao sentido do fraccionamento ocorrido no interior das classes dominantes (e em particular na nobreza) ao longo da Revolução. Pensamos, todavia, que a complexidade do problema continua a exigir um estudo mais completo, conceptualmente mais preciso e, sobretudo, melhor apetrechado para o aproveitamento crítico das fontes narrativas (sem descurar, no entanto, as fontes documentais).

$\left({ }^{20}\right)$ Vide F. Lopes, ob. cit., cap. CLXXVIII. 
exéquias solenes, constatamos o agravamento das dificuldades e contradições prenunciadas na década de setenta, materializado agora em acções de oposição directa à aclamação de D. Beatriz, filha de D. Fernando e de D. Leonor Teles, como rainha de Portugal $\left({ }^{30}\right)$. Nesta reacção distinguem-se as populações de cidades do centro e do sul do Reino, designadamente Lisboa, Santarém e Elvas $\left({ }^{31}\right)$, que a fazem acompanhar de algumas manifestações de simpatia para com o infante D. João, filho de D. Pedro I e de D. Inês de Castro $\left({ }^{32}\right)$, então ausente em Castela $\left(^{33}\right)$. O movimento assume a forma de motins populares, bastante localizados e de duração muito limitada, que não descambam ainda em práticas de violência muito acentuadas $\left({ }^{34}\right)$ e onde a participação (embora relativamente discreta) de elementos ligados à nobreza é já uma evidência $\left({ }^{35}\right)$. Tratar-se-á, afinal, de uma primeira medição

$\left.{ }^{(30}\right)$ Tal é o ponto de partida de um processo que (do ponto de vista interno e na sua dimensão político-militar) se irá desenvolver desde esta altura até bastante para além da solução formalmente encontrada em 6 de Abril de 1385, nas cortes de Coimbra, prolongando-se, pelo menos, até às proximidades do Natal de 1388 . O relato dos conflitos ocorridos neste período de aproximadamente cinco anos é-nos feito, como se sabe, por Fernão Lopes na sua Crónica de D. Fernando e, sobretudo, na Crónica de D. João I, que continuam a ser, infelizmente, as únicas fontes viabilizadoras de uma reconstituição de conjunto minimamente aceitável dos acontecimentos. em causa. E com base nelas (embora sem descurar as observações que outros autores a este propósito tenham emitido, designadamente quando documentalmente apoiadas ou de alguma forma clarificadoras dos temas em questão) que procuraremos distinguir os seus principais momentos.

${ }_{\left({ }^{31}\right)}$ Estas são as localidades expressamente referidas por Fernão Lopes, Crónica de D. Fernando, caps. CLXXV a CLXXVII. Contudo, o cronista afirma, no final deste último capítulo, que «acontecerom outros alvoroços em logares sobre o tomar da voz e alçamento de pendom, de que mais nom queremos dizer».

${ }_{\left({ }^{32}\right)}$ Assim o afirma F. Lopes, ob. cit., caps. CLXXV e CLXXVI, ao relatar as «uniões» ocorridas em Lisboa e Santarém, respectivamente.

$\left.{ }^{(33}\right)$ Vide nt. 26.

( $\left.{ }^{34}\right)$ Elvas terá sido a localidade em que os acontecimentos atingiram proporções mais drásticas (vide F. Lopes, ob. cit., cap. CLXXVII). Assinale-se, entretanto, que os promotores da aclamação de $D$. Beatriz revelaram, em geral, bastante prudência nas suas intervenções.

${ }^{\left({ }^{35}\right)}$ Se é certo que o carácter eminentemente popular destes movimentos nos é claramente sugerido por $\mathbf{F}$. Lopes (vide ob. cit., espec. cap. CLXXVI) parece-nos igualmente legítimo retirar da narrativa do cronista a ideia de uma nítida infiltração de elementos ligados à nobreza no seu desenvolvimento. Aliás, pensamos que a própria referência que é feita à figura do infante D. João (vide nt. 32) é a este propósito muito significativa. 
de forças, cujo prolongamento pensamos poder encontrar nos acontecimentos verificados em Lisboa pouco tempo depois (no dia 6 de Dezembro), em que é assassinado, nos próprios Paços da Rainha, o fidalgo João Fernandes Andeiro, conde de Ourém e valido de D. Leonor Teles, por um grupo de conjurados, maioritariamente nobres, encabeçado pelo Mestre de Avis, D. João, filho bastardo de D. Pedro I, e imediatamente secundado por um forte apoio popular $\left({ }^{36}\right)$. Este acto, desferido contra uma das principais figuras da corte, terá tido, contudo, o condão de radicalizar a evolução dos acontecimentos de uma forma inesperada e, seguramente, indesejada pela maioria dos seus promotores directos.

$\mathrm{Na}$ realidade, imediatamente após a eliminação do Conde João Andeiro, verificamos a erupção de um amplo movimento insurreccional nas zonas do centro e do sul do Reino que desencadeará, ao longo das últimas semanas de 1383 e nos primeiros dias de 1384, uma multiplicação de actos de violência praticados, de forma geralmente descontrolada, por camadas (urbanas e rurais) da população daquelas regiốes.

Assim, logo no dia 6 de Dezembro de 1383 (após os acontecimentos dos Paços da Rainha) registamos o alvoroço generalizado da população lisboeta, que acabará por traduzir-se no assassinato do respectivo bispo, D. Martinho, bem como do prior de Guimarães, Gonçalo Vaz, e do tabelião de Silves, que ocasionalmente com ele se encontravam no interior da Sé $\left({ }^{37}\right)$. No dia 30 de Dezembro verifica-se a ocupação do castelo de Lisboa, acompanhada da destruição de algumas das suas portas $\left({ }^{38}\right)$. Ao mesmo tempo, no Alentejo, constatamos o incêndio e ocupação do castelo de Beja, a tomada dos castelos de Portalegre e Estremoz e, em 2 de Janeiro de 1384, a ocupação, incêndio e destruição do castelo de Evora $\left({ }^{39}\right)$; nesta última localidade é também assassinada nesta altura a abadessa do mosteiro de S. Bento $\left({ }^{10}\right)$. Entretanto, outras

$\left({ }^{30}\right)$ Vide F. Lopes, Crónica de D. João $I$, 1. a parte, Lisboa, 1977, caps. IX e XI.

${ }^{\left({ }^{7}\right)}$ Vide Idem, Ibidem, caps. XI e XII. A bula de Urbano VI «Sede apostolica, pia mater», de 4 de Novembro de 1385 (Cf. doc. in J. Soares da Silva, Memórias para a história do reinado de D. João I, Lisboa, 1730, t. IV, p. 17), permite a identificação dos autores do crime (João da Veiga, Silvestre Esteves e Estêvão Afonso, cidadãos de Lisboa), objectos, aliás, da absolvição papal.

$\left({ }^{38}\right)$ Vide F. Lopes, ob. cit., cap. XLI.

$\left({ }^{39}\right)$ Vide Idem, Ibidem, caps. XLII a XLIV.

${ }^{\left({ }^{\circ}\right)}$ Vide Idem, Ibidem, cap. XLV. Na Monarquia Lusitana, VIII, p. 493, a abadesa é identificada como sendo D. Joana Ferreirim. 
movimentações se terão ainda registado: é o caso dos levantamentos promovidos pelas populações de Almada (em 1 de Janeiro) e do Porto, em favor da "causa do Mestre de Avis» ( $\left.{ }^{41}\right)$.

A partir dos primeiros meses de 1384 parece começar a detectar-se um gradual reordenamento das movimentações. O carácter mais radical das acções levadas a cabo nas semanas anteriores é progressivamente controlado e restabelece-se, lentamente, a conjugação de esforços entre as facções contestatárias que os primeiros acontecimentos subsequentes à morte de D. Fernando tinham evidenciado. E nestes termos que melhor poderemos compreender o desenvolvimento de uma nova fase, que situaremos cronologicamente entre os inícios de 1384 e meados de Fevereiro de 1385 e cuja principal característica consiste na concretização, por parte das forças políticas e sociais organizadas em torno da figura do Mestre de Avis, de uma grande campanha militar destinada a submeter, nas regiões da Estremadura e, sobretudo, do Alentejo, as povoações que se manifestavam hostis à sua causa.

O preâmbulo desta nova etapa ter-se-á verificado logo nos primeiros dias de 1384 e consistiu numa tentativa (fra. cassada) de conquista da vila de Alenquer pelas forças do Mestre ( $\left.{ }^{42}\right)$. Contudo, a grande operação militar só começa realmente em Abril, no Alentejo, sob o comando de Nuno Alvares Pereira, entretanto nomeado fronteiro da comarca de Entre-Tejo-e-Odiana $\left({ }^{43}\right)$. E assim que constatamos a tentativa (frustrada) de tomada do castelo de Monforte e a conquista de Arronches, entre 7 e 10 de Abril $\left({ }^{44}\right)$, e, pela mesma

(') Vide F. Lopes, ob. cit., respectivamente caps. LI e XLVI.

${ }^{\left({ }^{2}\right)}$ Vide F. Lopes, ob. cit., cap. LI. Situamos este facto na primeira semana de 1384 porque, segundo o cronista, a organização da expedição contra Alenquer terá ocorrido imediatamente após os acontecimentos de Almada, atrás referidos. Entretanto, Humberto Baquero Moreno, na sua Introdução à Crónica de D. João I de Fernão Lopes, Liv. Civilização, Porto, 1983, p. XI, afirma a existência de um documento revelador da presença de D. João em Lisboa no dia 7 de Janeiro.

${ }^{(3)}$ Parece-nos ter sido decisivo para o início desta «campanha do Alentejo» o êxito alcançado pelo exército de Nuno Alvares sobre tropas partidárias de I. João I de Castela, a 6 de Abril de 1384, em Atoleiros. (Vide F. Lopes, ob. cit., cap. XCV).

${ }^{\left({ }^{*}\right)}$ Estes episódios são referidos por F. Lopes, ob. cit., cap. XCVI. Através do seu relato não é, contudo, possível determinar com exactidão a data de pelo menos o $20^{\circ}$ destes acontecimentos, visto o texto ser manifestamente contraditório: após situar a partida de Nuno Alvares para Monforte no «seguimte dia depois da batalha, 
altura, a tomada, sem combate, do castelo de Alegrete $\left({ }^{45}\right)$, isto para além de outros acontecimentos que lhes surgem mais ou menos directamente associados e que se registam, ao longo dos restantes dias do mês de Abril, nas localidades alentejanas de Vila Viçosa, Alandroal, Elvas e Campo Maior $\left({ }^{46}\right)$.

Entretanto, a ofensiva de Nuno Álvares no Alentejo era completada mais a Norte com outras investidas. Assim, provavelmente no mesmo mês de Abril, uma força militar fiel ao Mestre de Avis, requisitada e apoiada pelos moradores de Alenquer, tenta, novamente debalde, a conquista deste castelo ( ${ }^{47}$ ); em 11 de Junho chega a Lisboa (entretanto sitiada

llogo pella manhãa» (refere-se à batalha de Atoleiros, que aconteceu a «huũa quarta feira de trevas no mes dabril»), o cronista acrescenta que Nuno Alvares esteve em Monforte «huũ dia» e que «em outro dia pella manhãa, que era dia dendoenças - isto é, quinta-feira santa - sse foi Nun'Alvares .... a Samta Maria do Açumar», onde recebeu recado de alguns portugueses de que podia tomar Arronches, para onde se dirigiu «Em outro dia gramde manhãa» e cujo castelo combateu de seguida, vitoriosamente. Segundo J. Vives, J. Augusti e P. Voltes, in Manual de Cronologia Española y Universal, Madrid, 1953, p. 192, a Páscoa recaiu, no ano de 1384, no dia 10 de Abril. Sendo asim, a quarta-feira de Trevas terá sido no dia 6 de Abril, data da batalha de Atoleiros. Segue-se, portanto, que Nuno Álvares terá partido para Monforte a 7 de Abril. Ora, ainda que aí tenha chegado no mesmo dia (o que é natural) e que o dia que aí esteve tenha sido o próprio dia da chegada (o que não é absolutamente claro), Nuno Alvares só partiu (segundo se retira do relato do cronista) para Santa Maria de Assumar no dia 8 de Abril, que não podia ser dia de Endoenças, pois a quinta-feira santa verificou-se, nesse ano, a 7 de Abril.... Sendo assim, torna-se impossível, sem outra fonte, datar exactamente a presença de Nuno Álvares em Assumar e, a partir daí, a tomada de Arronches. Em todo o caso, parece-nos razoável admitir que esta nunca se terá verificado para além do dia 9 ou 10 de Abril.

${ }^{\left({ }^{5}\right)}$ Vide F. Lopes, ob. cit., cap. XCVI. Relatando-a na sequência dos acontecimentos referidos na nota anterior, $F$. Lopes não fornece, porém, nenhuma datação para a tomada de Alegrete. Contudo, é de crer (dada até a proximidade geográfica entre as duas localidades) que ela se tenha processado imediatamente após a conquista de Arronches, ou mesmo paralelamente aos seus momentos finais (tendo em conta que não é Nuno Álvares, quem comanda pessoalmente a operação).

$\left({ }^{40}\right)$ Referimo-nos, concretamente, às disputas ocorridas (durante o estacionamento das tropas de Nuno Álvares no Alentejo) entre Vasco Porcalho e Alvaro Coitado e entre Paio Rodrigues e Gil Fernandes, relatadas por F. Lopes, ob. cit., caps. XCVII a CV e CVI a CVIII, respectivamente.

${ }^{\left({ }^{4}\right)}$ Vide F. Lopes, ob. cit., cap. CIX. O cronista não data este acontecimento; entretanto, a referência que faz à alegada presença do rei castelhano (certamente já a caminho de Lisboa) no Bombarral na mesma altura, permitirá supor que este episódio tenha ocorrido durante o mês de Abril. 
por D. João I de Castela) a notícia da tomada, sem combate, da vila de Ourém, adversária do Mestre, por Lopo Dias de Sousa, Mestre de Cristo ${ }^{\left({ }^{48}\right)}$.

Posteriormente, nos finais de Julho ou já durante o mês de Agosto ${ }^{\left({ }^{49}\right)}$, o exército de Nuno Alvares Pereira vem a ocupar o casteio de Monsaraz $\left({ }^{50}\right)$, para de seguida, encaminhando-se na direcção de Lisboa, saquear os arredores de Almada ${ }^{\left({ }^{61}\right)}$. Já no último trimestre de 1384, Nuno Alvares regressa ao Alentejo $\left({ }^{52}\right)$, toma o castelo de Portel e tentará ainda, sem êxito, conquistar Vila Viçosa $\left({ }^{53}\right)$.

Paralelamente, levantado o cerco castelhano a Lisboa, o Mestre de Avis comanda novas ofensivas militares: primeiro contra Almada, que consegue tomar, provavelmente em finais de Outubro ou inícios de Novembro $\left({ }^{54}\right)$, depois contra Alenquer, que ocupa, ao fim de seis semanas de cerco, em 10 de Dezembro ${ }^{55}$ ) (mas que voltaria a perder em 21 de Janeiro

${ }^{(48)}$ Vide Idem, Ibidem, cap. CXVI.

${ }^{(40)}$ Se tivermos em conta o movimento das tropas de Nuno Alvares e o facto de Lisboa se encontrar nesta altura cercada, o que se verifica entre 29 de Maio - ou 26 de Maio, no que diz respeito à frota castelhana - e 3 de Setembro. Entretanto, sobre a datação dos dois acontecimentos que se seguem, pode ver-se M. M. Wermers, «Nun'Alvares Pereira. A sua cronologia e o seu itinerário», Lusitania Sacra, t. V, Lisboa, 1960/61, pp. 25-28.

$\left({ }^{50}\right)$ Vide F. Lopes, ob. cit., cap. CXLIII.

$\left({ }^{(1)}\right)$ Vide Idem, Ibidem, cap. CXLVII. Note-se que a vila de Almada era, nesta altura, novamente adversária do Mestre, pois em 1 de Agosto de 1384 fora obrigada a render-se ao rei de Castela, após doloroso cerco (Vide Idem, Ibidem, cap. CXXXVII).

$\left.{ }^{(52}\right)$ O regresso de Nuno Alvares ao Alentejo terá sido pouco posterior à reunião promovida em 2 de Outubro de 1384, no Mosteiro de S. Domingos, pelo Mestre de Avis (Vide Idem, Ibidem, cap. CLIII). A este propósito, pode também ver-se M. M. Wermers, ob. cit., p. 30, que situa o acontecimento em meados de Outubro.

${ }^{(59)}$ Vide F. Lopes, ob. cit., respectivamente caps. CLVII e CLXXII. M. M. Wermers, ob. cit., p. 31, situa estes acontecimentos em Novembro e na segunda quinzena de Dezembro, respectivamente.

${ }^{(5)}$ Vide F. Lopes, ob. cit., cap. CLXV. A datação sugerida é baseada na proximidade deste acontecimento em relação a um outro: a largada (definitiva) da frota castelhana do Tejo, que H. B. Moreno, ob. cit., p. XII, situa (a partir de F. Lopes) em 28 de Outubro de 1384. Aliás, segundo este autor, o cerco de Almada decorre escassos dias depois do início dos preparativos do cerco de Torres Vedras (vide nt. 57), o que afirma ter ocorrido a 29 de Outubro (Idem, Ibidem). M. M. Wermers, ob. cit., p. 30, localiza, pelo seu lado, a tomada de Almada no dia 31 de Outubro.

${ }^{\left({ }^{*}\right)}$ Vide F. Lopes, ob. cit., caps. CLXVI a CLXVIII. H. B. Moreno, ob. cit., p. XIII, confirma a viabilidade desta datação, com base em cartas concedidas pelo Mestre, reveladoras da sua presença em Alenquer entre 5 de Novembro e 18 de Dezembro de 1384 
de $1385\left({ }^{56}\right)$ ) e finalmente contra Torres Vedras, de cujo cerco desistiria já nos princípios de Fevereiro de $1385\left({ }^{37}\right)$.

Entretanto, e pelo seu lado, o Mestre de Cristo tentara, sem êxito, a conquista de Torres Novas $\left({ }^{58}\right)$, enquanto no Norte a população portuense assaltara e destruíra o castelo de Vila Nova de Gaia, por alegadas arbitrariedades do respectivo alcaide $\left({ }^{59}\right)$.

Chegados aos meados de Fevereiro de 1385, constatamos uma interrupção dos confrontos militares; a atenção centra-se agora na preparação e realização das cortes de Coimbra e, por isso mesmo, as operações retomar-se-ão apenas após o seu encerramento.

Efectivamente, é entre a segunda quinzena de Abril de 1385 e os primeiros dias de Dezembro de 1388 que se completam as operações militares iniciadas no princípio do ano de 1384, através da subjugação, pelas forças do agora eleito D. João I de Portugal, das praças minhotas e transmontanas que persistiam em manter-se-lhe adversas.

A campanha começa pelo Minho. Logo em Abril de $1385\left({ }^{80}\right)$ Nuno Alvares Pereira toma o castelo de Neiva, conquista Viana e ocupa, sem combate, as localidades de Vila Nova de Cerveira, Monção e Caminha $\left({ }^{\left({ }^{1}\right.}\right)$. Em Maio, é a vez

( ${ }^{50}$ Vide F. Lopes, ob. cit., cap. CLXXIX.

("i) Vide Idem, Ibidem, caps. CLXVIII, CLXIX e CLXXX. Segundo refere H. B. Moreno, ob. cit., p. XIII (com base nos elementos indicados na nt. 55 e no cap. CLXVIII da Crónica, onde F. Lopes afirma que «o Meestre .... foi çercar Torres Vedras avemdo já seis domaas que chegara sobre Allamquer»), a presença do Mestre de Avis em Torres Vedras (cujo cerco se deverá ter iniciado nos últimos dias de Outubro - vide nt. 54) regista-se a partir de 19 de Dezembro. Adianta ainda H. B. Moreno que o Mestre aí deverá ter permanecido até meados de Fevereiro de 1385. M. M. Wermers, ob. cit., p. 33, situa - levantamento do cerco em 14 de Fevereiro.

${ }^{(28)}$ Vide F. Lopes, ob. cit., cap. CLXX. Decorre do relato do cronista que este acontecimento terá ocorrido entre Novembro de 1384 e Janeiro de 1385.

${ }_{\left({ }^{80}\right)}$ Vide Idem, Ibidem, cap. CLXXIII. Assinale-se a semelhança deste episódio com outros ocorridos durante a fase mais radical da Revolução (Dezembro de 1383 - Janeiro de 1384); aliás, é curioso sublinhar que a violência popular é, neste caso, exercida sobre um alcaide partidário do próprio Mestre de Avis e como forma de resistência à opressão senhorial.

$\left.{ }^{(0)}\right)$ o que se deduz do relato de Fernão Lopes, in Crónica de D. João I, II. ${ }^{\mathrm{a}}$ Parte, Lisboa, 1977, caps. I a V, designadamente da sequência dos acontecimentos que se sucederam ao encerramento das cortes de Coimbra. M. M. Wermers, ob. cit., pp. 33-35, compartilha, aliás, esta opinião.

( $\left.{ }^{{ }^{1}}\right)$ Vide F. Lopes, ob. cit., caps. VI a VIII. 
de D. João I tomar Guimarães ( ${ }^{82}$ ) e do Condestável conquistar Braga $\left({ }^{03}\right)$, para, de seguida, procederem ambos à tomada de Ponte de Lima $\left({ }^{64}\right)$.

Factores de ordem externa interrompem aqui a "campanha do Norte» $\left({ }^{65}\right)$, pelo que as acções militares em Trás-os-Montes só têm início perto do Natal, com a preparação e concretização (vitoriosa) do cerco de Chaves entre Janeiro e Abril de $1386\left({ }^{68}\right)$ e a ocupação, já no mês de Maio, de Bragança ${ }^{\left({ }^{67}\right)}$. Em Maio ou Junho proceder-se-á ainda, na região da Beira, à tomada de Almeida $\left({ }^{88}\right)$.

${ }^{\left({ }^{2}\right)}$ Vide Idem, Ibidem, caps. X e XI. Note-se contudo que, no cap. XIII, F. Lopes dá a entender que a vila de Guimarães só foi definitivamente entregue a D. João I no começo do mês de Junho. Isto não significa, porém, que o monarca aí tenha permanecido até essa altura. Com efeito, H. B. Moreno, ob. cit., p. XV, afirma que D. João esteve em Guimarães de 8 a 17 de Maio, para aí regressar entre 23 de Maio e 8 de Junho.

(as) Vide F. Lopes, ob. cit., cap. XIV. Pelo relato do cronista conclui-se que a conquista de Braga pelo Condestável ocorreu paralelamente à tomada de Guimarães por D. João I. M. M. Wermers, ob. cit., p. 35, inter-relaciona também os 2 acontecimentos.

(a) Vide F. Lopes, ob. cit., caps. XV a XVIII. Deduz-se claramente do texto de F. Lopes que na conquista de Ponte de Lima acabaram por participar o rei e o Condestável, e que esta se efectuou posteriormente às tomadas de Braga e Guimarães, atrás mencionadas. H. B. Moreno, ob. cit., p. XV, afirma, pelo seu lado, que a presença de $D$. João I em Ponte de Lima se verifica entre 19 e 21 de Maio, o que permite conciliar perfeitamente a sequência dos acontecimentos ocorridos em «Guimarães - Braga-Ponte de Lima-Guimarães» (v. notas anteriores). Sobre esta matéria pode também ver-se $M$. M. Wermers, ob. cit., pp. 35-36.

( $\left.{ }^{5}\right)$ Recorde-se que foi entre Junho e Outubro de 1385 que se feriram as célebres batalhas de Trancoso, Aljubarrota e Valverde. Foi, aliás, na sequência do segundo destes confrontos que D. João I pôde proceder à ocupação de um conjunto de vilas e castelos abandonados, que F. Lopes, ob. cit., cap. LXI, refere como sendo Santarém, Leiria, óbidos, Alenquer, Torres Vedras, Torres Novas, Sintra, Crato, Monforte, Vila Viçosa, Marvão «e outros que nom dizemos».

$\left.{ }^{\infty}{ }^{\infty}\right)$ Vide F. Lopes, ob. cit., caps. LXIV e LXIX. A datação sugerida pelo cronista é, no essencial, confirmada por H. B. Moreno, «A Vila da Torre de Moncorvo no reinado de D. João I», Estudos Medievais, n. ${ }^{\circ}$ 2, Porto, 1982 , pp. 33-34, que com base na Chancelaria de D. João I, liv. 2, fol. 1 v. e liv. 2, fol. 26, situa, respectivamente, o começo do cerco em 15 de Janeiro de 1386 e a tomada da vila em 30 de Abril do mesmo ano.

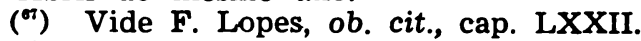

${ }^{\left({ }^{8}\right)}$ Vide Idem, Ibidem, cap. LXXIII. De acordo com H. B. Moreno, Introdução..., p. XVIII, a reconstituição do itinerário régio permite indicar a presença de D. João I em Almeida no dia 6 de Junho de 1386. M. M. Wermers, ob. cit., p. 50, baliza a tomada desta vila beirã entre 27 de Maio e 6 de Junho. 
Intercalada nesta altura com a realização de incursões fronteiriças em Castela, a campanha finalizará entre Janeiro e Março de 1388, com o cerco e rendição da vila de Melgaço, no Alto Minho, por D. João I $\left({ }^{69}\right)$.

Extintos em todo o reino os principais focos de resistência armada ao poder constituído, encontrava-se agora praticamente terminado o processo de confrontação político-militar que os acontecimentos do último trimestre de 1383 haviam precipitado a nível interno. 0 cerco vitorioso da vila alentejana de Campo Maior, comandado pelo jovem rei entre 15 de Setembro de 1388 e o $1 .^{\circ}$ de Dezembro do mesmo ano $\left({ }^{70}\right)$ parece assumir precisamente esse significado.

Contudo, é perfeitamente claro que se o Natal de 1388 simbolizou no Reino de Portugal a conclusão de um prolongado e doloroso processo de afirmação interna do novo poder gerado pela Revolução, ele não lhe trouxe, em contrapartida, uma acalmia política absoluta.

Com efeito, profundas divergências que, praticamente desde o início da Revolução, haviam por várias vezes comprometido a unidade do próprio "partido triunfante" $\left({ }^{71}\right)$, mas que os imperativos e liberalidades da guerra e a ameaça externa tinham sistematicamente camuflado, alcançam agora, à entrada dos anos 90 , nova actualidade.

Penso que é aqui que se integra, designadamente, a extensa fractura interna que atingirá a nobreza apoiante de D. João I, ocorrida após o chamamento geral promovido pelo monarca $\left({ }^{72}\right)$ e de que resulta, pelo menos, uma grave discórdia

${ }^{\left({ }^{80}\right)}$ Vide F. Lopes, ob. cit., caps. CXXXIV a CXXXVI. Segundo H. B. Moreno, ob. cit., p. XXII, as cartas régias revelam-nos a presença do monarca em Melgaço, entre 4 de Fevereiro e 8 de Março de 1388. De acordo com este autor, o cerco da vila dever-se-á ter iniciado por volta do dia 10 de Janeiro, para a sua conclusão se efectuar exactamente 53 dias após, a 3 de Março de 1388. Entretanto, M. M. Wermers, ob. cit., p. 58, situa o cerco de Melgaço entre 31 de Janeiro e 25 de Março.

${ }^{(0)}$ Vide F. Lopes, caps. CXXXVI e CXXXVIII. Segundo $H$. B. Moreno, ob. cit., p. XXIII, os documentos régios expedidos do arraial de Campo Maior prolongam-se até finais de Novembro de 1388, o que confirma a narrativa do cronista.

( $\left.{ }^{71}\right)$ Nem F. Lopes escamoteia este facto, como facilmente se depreende de muitas passagens da sua Crónica de $D$. João I. Não nos interessa, entretanto, explorar aqui profundamente esta ideia, de acordo com o que dissemos na nt. 28.

${ }^{(2)}$ Vide F. Lopes, ob. cit., cap. CLIII. O cronista não data o acontecimento. Entretanto, H. B. Moreno, ob. cit., p. XXVI, afirma que ele terá ocorrido no ano de 1393, provavelmente no mês de Dezembro, altura em que o rei se encontrava em Atouguia (o que é, 
com Nuno Alvares Pereira $\left({ }^{73}\right)$ e, sobretudo, poucos anos depois, a deserção em massa para Castela de muitos dos mais importantes fidalgos da Beira, alguns dos quais haviam desempenhado funções políticas e militares de relevo junto do rei português $\left({ }^{74}\right)$. Vários deles acabarão mesmo por vir a participar em incursões castelhanas em Portugal, de duração e proporções assinaláveis $\left({ }^{75}\right)$.

Ainda que de uma forma naturalmente menos exuberante do que até então, as dissidências políticas que cruzavam a sociedade portuguesa dos finais do século XIV prolongaram-se, portanto, para além do rescaldo da Revolução de 1383-85. Os últimos acontecimentos atrás referidos são disso o prenúncio indesmentível.

Tal não obstou, contudo, a que o governo de D. João I se prolongasse até 1433, sem que haja notícia de qualquer outro incidente político violento. 0 mesmo se passa, aliás, em relação ao monarca seguinte, $D$. Duarte, em cujo breve reinado parecem, no entanto, começar já a detectar-se indícios de novos e importantes sobressaltos $\left({ }^{78}\right)$. E o facto é que

aliás, confirmado por Maria Alice Pombo, Itinerário d'El-Rei D. João I, 1388-1398, Coimbra, 1961, tese de licenc., dactil., pp. 124 e 125). Conforme relata $F$. Lopes, o objectivo principal da reunião consistia na compra, por parte do monarca, de terras que anteriormente havia doado aos fidalgos, com vista ao engrandecimento do património régio. M. M. Wermers, ob. cit., pp. 63-64, situa estes acontecimentos entre Novembro de 1393 e Março de 1394.

$\left.{ }^{(73}\right)$ De acordo com o próprio F. Lopes, ob. cit., cap. CLIV, Nuno Alvares (então já grande proprietário dominial) chega a decidir «hir fora do reyno a buscar sua vida», só a muito custo tendo sido demovido dessa intenção.

(14) E, sobretudo, o caso de Martim Vasques da Cunha (figura destacada da defesa da candidatura do infante $D$. João, filho de Inês de Castro, nas cortes de Coimbra de 1385) e de seus irmãos, Gil Vasques da Cunha (ex-alferes-mor do Reino) e Lopo Vasques da Cunha, e também o de João Fernandes Pacheco e de vários outros. Estas deserçóes, geralmente acompanhadas da entrega dos respectivos castelos e vilas aos castelhanos, ocorrem entre 1396 e 1398 e delas nos dá conta (embora de uma forma algo mitigada) F. Lopes, ob. cit., design. caps. CLIX e CLXVIII.

${ }^{(55}$ ) Veja-se, por exemplo, o relato que é feito por F. Lopes, ob. cit., cap. CLX, da invasão e incêndio da cidade de Viseu, em 1397, promovidos por Rodrigo de Avalos, Condestável de Castela, acompanhado de Martim Vasques da Cunha e seus irmãos.

$\left.{ }^{76}\right)$ Pensamos que, a este propósito, será significativa a mudança registada na orientação da política expansionista portuguesa, de novo mais centrada nas conquistas no Norte de Africa. Da mesma forma, parece-nos que a situação interna do Reino em 1433, ano em que D. Duarte assume o poder, não era de molde a fazer prever um reinado demasiado tranquilo. Aliás, Armindo de Sousa, «As Cortes 
a sua morte, ocorrida em 1438, viria a (re)abrir uma crise política de indiscutível gravidade, que acabaria, em última análise, por se arrastar até Maio de 1449.

Funcionou, desta feita, como detonador, o facto de, à hora da morte de D. Duarte, seu filho primogénito ser ainda de menor idade, tornando-se por isso necessário encontrar uma solução de continuidade para a ocupação do poder. Tal solução era sugerida, no seu testamento, pelo próprio monarca falecido: entrega total e exclusiva da regência do Reino à rainha viúva, D. Leonor de Aragão, até à maioridade do infante D. Afonso $\left({ }^{77}\right)$. Esteve, contudo, longe de ser uniforme a reacção da alta nobreza de Portugal ao teor deste documento. Comprovam-no as movimentações políticas imediatamente desencadeadas no interior da corte e as pressões, de origem e objectivos diversos, então exercidas sobre D. Leonor; o ambiente de tensão assim gerado acaba, de resto, por reflectir-se nas sessões preparatórias das cortes convocadas para o mês de Novembro, em Torres Novas ${ }^{78}$ ). Nestas, acabaria por aprovar-se, em grande parte devido à intervenção decidida dos infantes, filhos de D. João I, e à determinação evidenciada pelos procuradores de alguns concelhos (designadamente de Lisboa), um projecto de regimento conciliatório, substancialmente diverso do preconizado pelo extinto monarca e cuja principal característica consistia na elevação do infante D. Pedro (o mais velho dos filhos de D. João I ainda vivos) à condição de co-regente, em companhia de sua cunhada, D. Leonor $\left({ }^{79}\right)$.

Não durou muito, contudo, esta precária solução de compromisso, pois a tensão existente, ao que parece de há

de Leiria-Santarém de 1433», Estudos Medievais, n.ํ 2, Porto, 1982, pp. 71-224, chama precisamente a atenção para o descontentamento manifestado pelos povos em relação ao estado desleixado em que se encontrava a administração do Reino, exigindo reformas profundas mas que não atentassem contra os seus privilégios.

$\left.{ }^{(77}\right)$ Vide Ruy de Pina, Chronica do Senhor Rey D. Affonso V, Collecção de Livros Ineditos da Historia Portuguesa, t. I, Lisboa, 1790, cap. III, pp. 207-208.

${ }^{(78)}$ Acerca desta matéria pode ver-se H. B. Moreno, A Batalha de Alfarrobeira - antecedentes e significado histórico, Coimbra, 1979 , pp. 7 a 10.

(') Cf. doc. in Artur Moreira de Sá, Alguns documentos referentes ao Infante D. Pedro, sep. da Revista da Faculdade de Letras, t. XXII, 2.a série, n. 1 , Lisboa, 1956 , doc. n..$^{\circ}$ II, pp. 31 a 39 . Segundo R. Pina, ob. cit., cap. XV, pp. 224-226, o projecto de regimento aprovado era da autoria do infante $D$. Henrique, tendo a sua ratificação por todas as partes sido autenticamente forçada pelos representantes
dos povos. 
muito $\left({ }^{80}\right)$, entre os dois governantes, avolumava-se progressivamente e consentia, se não mesmo alimentava, a instalação de um clima insurreccional que atingiu, pelo menos, a cidade de Lisboa e que levou, logo em 1439, a graves incidentes na câmara desta cidade, de que resultou o defenestramento de um funcionário da rainha e a perseguição de outros $\left({ }^{81}\right)$. Com efeito, em Setembro desse ano, dissolvia-se definitivamente o projecto de governo bi-partido $\left({ }^{82}\right)$, não tardando a registar-se novos e graves desacatos em Lisboa, desta feita visando os bens e a pessoa do Arcebispo D. Pedro de Noronha, figura muito próxima de $\mathrm{D}$. Leonor $\left({ }^{83}\right)$.

Extremava-se, de novo, a situação: antecipando-se às cortes convocadas para o mês de Dezembro em Lisboa, a população desta cidade, claramente enquadrada por elementos ligados à nobreza, aprova, em reunião promovida na câmara em princípios de Outubro, um documento exigindo a passagem, sem partilha, da regência para o infante D. Pedro $\left({ }^{84}\right)$. O assalto ao castelo de Lisboa e a sua entrega a um partidário deste último (no caso o infante D. João, seu irmão) ${ }^{85}$ ) culminam, na capital, as aç̧ões revolucionárias desencadeadas pelas forças que propugnavam o afastamento de $\mathrm{D}$. Leonor da cena política portuguesa. Tal desejo acabaria, aliás, por encontrar plena consagração nas cortes iniciadas no dia 10

(80) De acordo com H. B. Moreno, ob. cit., p. 6, nt. 7, «o antagonismo existente entre o Infante $D$. Pedro $e$ D. Leonor parece dever-se fundamentalmente a velhas querelas familiares que ensombraram as relaçōes entre os Trastâmaras e os Urgeis».

(11) Vide R. Pina, ob. cit., cap. XXIV, pp. 237-239. Sobre o alastramento do clima insurreccional em Lisboa vide Idem, Ibidem, cap. XXV, pp. 239-242. Desconhecemos a data exacta destes incidentes.

${ }^{82}$ ) Segundo afirma H. B. Moreno, ob. cit., p. 34, com base na Chancelaria de $\mathrm{D}$. Afonso $\mathrm{V}$, «o último documento conhecido assinado pelos co-regentes tem a data [...] de 16 de Setembro de 1439».

$\left.{ }^{(}\right)$Sobre este incidente cf. doc. in Virgínia Rau, $O$ Infante D. Pedro e a regência do reino em 1439, sep. da Revista da Faculdade de Letras, III série, n. ${ }^{\circ}$, Lisboa, 1964, pp. 149-150.

De acordo com H. B. Moreno, ob. cit., p. 35, estes novos incidentes ter-se-ão verificado entre 16 e 25 de Setembro.

( ${ }^{\text {s) }}$ Cf. doc. in Monumenta Henricina, t. VI, Coimbra, 1964, doc. n. ${ }^{\circ} 109$, pp. 293-295. Sobre o teor do documento aprovado pode ver-se também $R$. Pina, ob. cit., cap. XXXVII, pp. 256-257. O carácter socialmente heterogéneo da reunião da câmara de Lisboa é-nos claramente denunciado por aquele cronista, ob. cit., cap. XXXVI, pp. 254-255, que, para além, obviamente, de elementos do povo (como, por exemplo, o tanoeiro Lopo Fernandes) nos refere também a presença não só do célebre jurisconsulto Diogo Afonso Mangancha, como ainda de Alvaro Vasques de Almada (o famoso «Capitam») e de Rui Gomes da Grã, «outro sy cidadaaõ ,e de bõo e antyga linhagem».

${ }_{\left({ }^{2}\right)}$ Vide $R$. Pina, ob. cit., cap. XLI, pp. 263-265. 
de Dezembro, que, com extrema facilidade e sem que D. Leonor e os partidários que lhe restavam se lhes pudessem minimamente opôr, procederam à anulação das decisões das anteriores cortes de Torres Novas e ratificaram o documento aprovado em Outubro na câmara de Lisboa, entretanto subscrito por grande número de cidades e vilas do Reino $\left.{ }^{(86}\right)$. Investido pelo próprio rei durante as cortes, objecto do apoio de seus irmãos e de uma facção importante da alta nobreza e alvo de uma generalizada simpatia popular (a que procurou corresponder no imediato) D. Pedro via-se assim, ao iniciar-se o ano de 1440, elevado a uma posição de indiscutível primazia $\left({ }^{87}\right)$.

Tal posição permitiu-lhe, de uma forma peremptória e aparentemente simples, contrariar as pretensões de sua cunhada que, no primeiro semestre de 1440, foge de Sintra para Almeirim e depois, já nos finais de Outubro, para o Crato, de acordo com desígnios algo obscuros, em que aparecem envolvidos o Prior do Crato, o conde de Barcelos (D. Afonso, filho natural de D. João I) e, curiosamente, alguns importantes fidalgos da Beira, além dos infantes de Aragão, irmãos de D. Leonor $\left({ }^{88}\right)$. Com efeito, frustradas algumas tentativas mediadoras e mobilizada a população lisboeta e a do seu ducado de Coimbra para a eventualidade de

(\$) Vide Idem, Ibidem, cap. XLVI, pp. 272-274. H. B. Moreno, ob. cit., pp. 56-58, adianta (com base na carta do regente à câmara de Lisboa de 24 de Janeiro de 1442, publ. in Monumenta Henricina, VII, Coimbra, 1965, doc. n. ${ }^{\circ} 15$, pp. 18-23) que, significativamente, 72 cidades e vilas do Reino assinaram o acordo saído da reunião de Outubro da câmara de Lisboa e agora ratificado nas cortes, apoiando assim a candidatura de $D$. Pedro a uma regência «in solydo».

Assinale-se, entretanto, que os capitulos gerais e respectivas respostas destas cortes se encontram transcritos por Maria Regina Marques Moreira, As côrtes de Lisboa de 1439, Univ. Coimbra, 1953 (tese de licenc., dactil.).

$\left.{ }^{(87}\right)$ Com efeito, é notório o empenhamento de, pelo menos, dois dos irmãos de $\mathrm{D}$. Pedro no processo que o elevou à condição de único regente: $\mathrm{D}$. Henrique e $\mathrm{D}$. João. $£$, aliás, este último quem funciona como emissário junto da rainha para tornar possivel a vinda do jovem rei às cortes (vide $R$. Pina, ob. cit., cap. XLVIII, p. 276). Da mesma forma, é evidente o grande apoio popular que D. Pedro consegue obter (vide nt. anterior) e a maneira como ele o procura, na ocasião, estimular, através da concessão de inúmeros privilégios aos concelhos, designadamente, como é natural, ao de Lisboa (Cf. doc. in Maria Regina M. Moreira, ob. cit., Apêndice, pp. I a LIII).

${ }^{(88)}$ Vide R. Pina, ob. cit., espec. caps. LV (pp. 294-296), LVIII (pp. 300-301), LIX (pp. 301-302) e LXI (pp. 303-304); H. B. Moreno, ob. cit., espec. pp. 77-78. 
uma guerra generalizada $\left({ }^{89}\right)$, D. Pedro procede, com o apois de seus irmãos, a uma operação militar contra fortalezas do priorado do Crato. Assim, Lopo de Almeida toma, em 17 de Dezembro, o castelo de Belver e Alvaro Vasques de Almada o da Amieira, para o próprio D. Pedro cercar e conquistar, em 17 de Janeiro de 1441 o castelo do Crato $\left({ }^{90}\right)$. Isolada (apesar do auxílio prestado pelo fidalgo castelhano Afonso Henriques, que chega mesmo a promover um assalto às localidades de Cabeço de Vide e Alter do Chão), D. Leonor acabara por fugir, em 29 de Dezembro de 1440, para Castela $\left({ }^{91}\right)$, de onde não viria nunca a regressar.

Afastada a rainha-viúva, restava a $\mathrm{D}$. Pedro neutralizar eventuais focos de desestabilização interna, polarizados no Norte em torno da figura de seu meio-irmão D. Afonso, conde de Barcelos - o que consegue logo no primeiro trimestre de 1441, através de uma expedição militar de que resulta, sem que se verifique qualquer confronto, o estabelecimento de um acordo entre os dois infantes $\left({ }^{92}\right)$ - e preparar o Reino para o enfrentamento de uma possível intervenção externa que, contudo, e pese embora os múltiplos esforços desenvolvidos

(89) Cf. docs. in Monumenta Henricina, VII, Coimbra, 1965, doc. n. ${ }^{\circ} 114$, pp. 183-184 (carta do regente ao concelho de Lisboa, em 1 de Novembro de 1440), e Belisário Pimenta, As Cartas do Infante D. Pedro à Câmara de Coimbra (1429-1448), Coimbra, 1958, doc. n. LVI, pp. 53-54 (carta do Regente ao concelho de Coimbra, em 2 de Novembro de 1440).

${ }^{(0)}$ Vide R. Pina, ob. cit., caps. LXX (pp. 316-317) e LXXIV (pp. 322-325). Este cronista não indica a data exacta da conquista do castelo do Crato, mas H. B. Moreno, Os Itinerários do Infante D. Pedro (1438-1448), sep. da Revista de Ciências do Homem, Univ. de Lourenço Marques, vol. I, série $B, 1968$, pp. 66-67, situa-a em 17 de Janeiro de 1441, com base na Chancelaria de D. Afonso V, liv. 2, fol. $121 \mathrm{v}$.

( $\left.{ }^{{ }^{1}}\right)$ Vide R. Pina, ob. cit., caps. LXXII (pp. 319-320) e LXXIV (esp. p. 323). De acordo com H. B. Moreno, A Batalha..., p. 92, o isolamento de $\mathrm{D}$. Leonor nesta altura resultava em boa parte da falta do auxílio que D. Afonso, conde de Barcelos, e outros fidalgos lhe haviam prometido (pelos vistos em vão, dado que acabaram por decidir evitar uma intervenção directa contra $D$. Pedro e os seus - muitos - apoiantes, numa tal conjuntura política e militar).

${ }^{\left({ }^{82}\right)}$ Vide R. Pina, ob. cit., cap. LXXV, pp. 326-329. A campanha de $D$. Pedro explica-se perfeitamente em função das posições anteriormente assumidas pelo conde de Barcelos (vide designadamente, nts. 88 e 91). Segundo o cronista, o acordo foi conseguido em Lamego, sendo seu mediador o conde de Ourém (filho do infante $\mathrm{D}$. Afonso e partidário, nesta altura, de $\mathrm{D}$. Pedro) e a ele tendo assistido o Arcebispo de Braga, D. Fernando da Guerra. H. B. Moreno, ob. cit., pp. 54-55 (esp. nt. 22) contesta a datação sugerida por R. Pina para o acontecimento, não podendo, contudo, precisar a sua altura exacta. 
por D. Leonor nesse sentido, acabaria por não chegar a consumar-se $\left.{ }^{93}\right)$. O falecimento de D. Leonor, em Fevereiro de 1445, em Toledo, liquidaria definitivamente esta possibilidade. O duque de Coimbra pôde assim, praticamente desde os inícios de 1441, exercer a regência que lhe tinha sido atribuída, de uma forma incontestada. $\mathbf{O}$ carácter fortemente reformador que lhe imprimiu, bem como a própria transitoriedade - de todos conhecida - do seu exercício do poder, reservavam-lhe, contudo, sérios dissabores.

$\mathrm{Na}$ verdade, a 15 de Janeiro de 1446 (data em que o pequeno rei perfazia 14 anos de idade, atingindo, por isso, a maioridade para governar), viu-se D. Pedro na obrigação de entregar o regimento a seu sobrinho D. Afonso. Para esse efeito, encontravam-se reunidas, na cidade de Lisboa, as cortes do Reino. Delas resultou, contudo, por meios e artifícios ainda não totalmente esclarecidos, a devolução da regência ao mesmo infante D. Pedro, segundo vontade expressa do Rei, que a fazia acompanhar de uma significativa carta de louvor a seu tio, pelos serviços prestados como governante ao longo dos anos anteriores $\left({ }^{94}\right)$.

D. Pedro via assim prolongada a sua condição de regente de Portugal. Porém, não mais terá podido dispôr da estabilidade necessária ao exercício da governação. $\mathrm{Na}$ verdade, se nas cortes de Lisboa já eram evidentes os sinais de descontentamento em relação à evolução dos acontecimentos (tanto por parte de sectores da nobreza como por parte dos representantes do povo, a quem a orientação política imprimida por D. Pedro estava longe de agradar), a partir de então a situação agravar-se-á progressivamente, tornando-se mesmo, a partir do primeiro semestre de 1448, praticamente incom-

${ }^{\left({ }^{\infty}\right)} \mathrm{O}$ perigo de uma intervenção militar estrangeira resultava, obviamente, da ligação de D. Leonor aos infantes de Aragão, seus irmãos. Ciente disso, D. Pedro desenvolvia já há algum tempo grandes esforços para conseguir uma forte aliança com o Condestável de Castela, D. Alvaro de Luna, o que veio, de facto, a consumar-se (vide R. Pina, ob. cit., caps. LV e LVI, pp. 294-298). Em todo o caso, o Regente não descurou, como é natural, os preparativos internos do Reino para uma tal eventualidade, para isso celebrando cortes em Evora entre 25 de Janeiro e 5 de Fevereiro de 1442 (vide $\mathrm{H}$. B. Moreno, Os Itinerários..., p. 12; R. Pina, ob. cit., cap. LXXXIX, pp. 334-337) e mobilizando, de novo, os concelhos (Cf. doc. in Belisário Pimenta, ob. cit., doc. n. ${ }^{\circ}$ LV, p. 65 - carta de D. Pedro aos «cavaleiros. escudeiros e homees boos» de Coimbra, de 20 de Dezembro de 1442).

(") Cf. doc. in H. B. Moreno, A carta de louvor ao infante D. Pedro de 15 de Janeiro de 1446, sep. da Revista de Ciências do Homem, série A, II (1), Lourenço Marques, 1969. 
portável ( $\left.{ }^{95}\right)$; não é, portanto, de estranhar que, entre 8 e 10 de Julho deste ano, D. Pedro se tivesse visto constrangido a terminar as suas funções como regente $\left({ }^{96}\right)$. A (2.. $)$ carta de louvor que lhe dedica nessa altura $\mathrm{D}$. Afonso $\mathrm{V}$, bem como as mercês que se lhe sucedem $\left({ }^{07}\right)$, mal disfarçam o ambiente de tensão em que todos estes acontecimentos decorrem, o que motiva, a breve trecho, o afastamento de D. Pedro da corte e o desencadeamento no Norte, pelo conde de Barcelos (agora também duque de Bragança), de violentas aç̧ões punitivas sobre conhecidos partidários do antigo regente $\left({ }^{98}\right)$.

O Reino conhece então, nos meses que decorrem entre Agosto de 1448 e Janeiro de 1449, um período de grande agitação política, em que se multiplicam as críticas ao ex-regente e as represálias contra seus apaniguados e se sucedem as tentativas apaziguadoras e as intrigas palacianas $\left({ }^{90}\right)$.

${ }^{\left({ }^{95}\right)}$ Acerca das circunstâncias que rodearam a regência de D. Pedro entre Janeiro de 1446 e Julho de 1448, pode ver-se D. António Caetano de Sousa, Provas da História Genealógica da Casal Real Portuguesa, t. III, Lisboa, 1744, pp. 505-508 (texto integral da carta de $D$. Afonso, conde de Barcelos, às cortes de Lisboa de 1446); H. B. Moreno, A Batalha..., pp. 249-251 (transcr. parc. dos capitulos especiais de Lisboa e de Tavira nas cortes de Lisboa de 1446, reveladores do descontentamento em relação à política do Regente); Idem, Ibidem, pp. 256-258 (sobre a confirmação de bens próprios obtida por D. Pedro junto de D. Afonso V, em 17 de Abril de 1447); Artur Moreira de Sá, «O Infante D. Pedro e a crítica histórica», Revista da Faculdade de Letras, t. XVI, 2.a série, n. $0^{\circ} 3$, Lisboa, 1950, pp. 124-136 (texto integral da carta de D. Pedro ao conde de Arraiolos, de 30 de Dezembro de 1448, narrando os episódios ocorridos na última fase da regência).

$\left.{ }^{\infty}{ }^{\infty}\right)$ Segundo H. B. Moreno, ob. cit., p. 259, o último documento assinado por D. Pedro na qualidade de regente data de 8 de Julho de 1448; pelo seu lado (e como, aliás, o mesmo autor também refere), Belisário Pimenta, ob. cit., doc. n. ${ }^{\circ}$ LXXIII, p. 72, apresenta uma carta à câmara de Coimbra, com data de 10 de Julho de 1448, assinada por D. Pedro a título meramente pessoal (e não já como regente).

${ }_{\left({ }^{\circ 7}\right)} \mathrm{Cf}$. doc. in A. M. Sá, Alguns documentos...., doc. n. ${ }^{\circ}$, pp. 62-65. Sobre as mercês concedidas por D. Afonso a seu tio, em 12 de Julho de 1448, veja-se H. B. Moreno, ob. cit., p. 261.

${ }_{\left({ }^{83}\right)}$ Cf. A. M. Sá, doc. cit. na nt. 95; nesta carta, D. Pedro refere-se às acções do duque de Bragança nos seguintes termos: «... E logo o duque meu irmãao, vosso padre, transnoutamdo asi como se ouvesse de fazer algũa gramde caualgada, se vejo de chaues a çidade do porto, temdo ja em ella homens darmas escondidos, lamçando fora della muj desmorradamente os meus que hi viuiam, assi como se fossem mal feitores. $E$ este mesmo mandou fazer em guimaraes e em pomte de lima, derribando as casas de lionel de lima, por ser meu seruidor, asi como se fosse de tredor. $E$ quando os lançaua fora das villas, chamaualhe tredores, vellando e rroubamdo as villas e castellos sem causa e sem Rezam, assi como se tiuessem jmiguos no Regnon. 323-343.

$\left.{ }^{(0)}\right)^{\circ}$ Sobre esta matéria veja-se H. B. Moreno, ob. cit., pp. 
A agudização extrema da situação torna, pois, transparente a iminência de um confronto físico generalizado, que qualquer pretexto, a todo o momento, podia desencadear.

Em Fevereiro de 1449, e na sequência de algumas medidas restritivas da capacidade de intervenção de $D$. Pedro, a corte chama a Santarém o duque de Bragança, com a indicação expressa de este se fazer acompanhar da sua hoste e de fazer trajecto através das terras do ducado de Coimbra $\left({ }^{100}\right)$. D. Pedro opõe-se firmemente, apesar do mandato régio de princípios de Abril, obrigando o seu meio-irmão a desviar caminho para atingir Santarém $\left(^{101}\right)$.

Este acto de rebeldia (porventura esperado) do antigo regente, conduziu inexoravelmente à precipitação dos drásticos acontecimentos que há já algum tempo se aguardavam. Com efeito, D. Afonso V não teve grande dificuldade em capitalizar a seu favor o descontentamento de vastos sectores da nobreza e dos meios populares - mesmo de cidades como Lisboa, cujo comportamento havia sido decisivo nos episódios de finais de $1439{ }^{\left({ }^{102}\right)}$ - e em conseguir, a partir daí, uma posição de

${ }^{(100)}$ Vide R. Pina, ob. cit., cap. XCVI, pp. 374-376. O cronista, no entanto, situa o acontecimento em princípios de Outubro de 1447, $\checkmark$ que é manifestamente descabido, conforme nota $H$. B. Moreno, ob. cit., p. 344 , nt. 155 , que sugere, fundamentadamente, a data de Fevereiro de 1449.

$\left({ }^{101}\right)$ Vide R. Pina, ob. cit., cap. XCIX, pp. 378-382. Acerca do trajecto que $o$ duque de Bragança acabou por percorrer para atingir Santarém, deve ver-se o trabalho de Gastão de Melo Matos, Itinerário do Duque de Bragança em 1449, sep. da Revista Portuguesa de História, t. V, Coimbra, 1951.

${ }^{\left({ }^{102}\right)}$ De facto, D. Pedro encontra-se nesta altura fortemente isolado, o que pode parecer surpreendente se nos recordarmos da situação de grande popularidade em que assumiu, em Dezembro de 1439 , a regência do Reino (vide nt. B7). Esta reviravolta só pode encontrar explicação na política centralizadora desenvolvida pelo Regente, que provocou uma considerável restrição na atribuição de doaçōes (como claramente comprova H. B. Moreno, ob. cit., pp. 307-319), o que terá desagradado à alta nobreza do Reino (parece-nos particularmente curiosa a «mudança de partido» protagonizada, durante a regência, pelo conde de Ourém e outros fidalgos de nomeada), e provocou também o descontentamento do terceiro Estado, à custa de quem se construia, em grande medida, o reforço do poder régio (as intervenções dos procuradores dos concelhos nas cortes de Lisboa de 1448 são, a este propósito, muito significativas). Finalmente (e como, oportunamente, nota H. B. Moreno, ob. cit., design. pp. 565-567), a rebeldia evidenciada por $\mathrm{D}$. Pedro em relação às determinaçōes régias terá afastado dele grande parte dos juristas mais importantes e, inclusivamente, o seu próprio irmão D. Henrique (Idem, Ibidem, pp. 356-357, esp. nt. 251). 
clara hegemonia $\left({ }^{103}\right)$. As cartas régias contra o infante transformam-se em verdadeiros ultimatos que $D$. Pedro, no entanto, ignora, encetando, a partir do seu ducado e com uma finalidade algo duvidosa, uma marcha militar em direç̧ão a Lisboa, que tem o seu início na primeira semana de Maio ${ }^{104}$ ). Após uma escaramuça, no dia 16, em Alcoentre, as tropas do infant: encontram-se no dia 20 em Alfarrobeira com o exército real, que entretanto saíra de Santarém ao seu encontro ( $\left.{ }^{105}\right)$; a refrega foi, afinal, curta, tendo o exército de D. Afonso V imposto a sua superioridade numérica esmagadora e dela resultando a morte de D. Pedro e dos seus principais companheiros.

Ficava assim praticamente encerrado um novo e intenso período de agitação política em Portugal $\left({ }^{100}\right)$, a que apenas a força das armas conseguiu pôr cobro. Provisoriamente, talvez; em todo o caso, o reinado de $\mathrm{D}$. Afonso V prolongar-se-ia ainda até 1481 , sem que (para além de algumas disputas com o clero relativamente delimitadas e de expressão pouco rele-

${ }^{(103)}$ Sobre esta matéria, é deveras elucidativo o quadro apresentado por H. B. Moreno, ob. cit., pp. 408-418, onde se constata que, nos inícios de 1449,61 dos 67 alcaides de castelos portugueses eram partidários de $\mathrm{D}$. Afonso V. Tal situação terá facilitado a operação desencadeada em Abril de 1449, no Alentejo, contra o Condestável D. Pedro, visando anular qualquer possibilidade de auxílio militar deste a seu pai (o infante D. Pedro). Com efeito, são nesta altura submetidos, sem combate, os castelos de Olivença, Elvas, Castelo de Vide e Marvão, acabando o Condestável por ter de refugiar-se em Castela (Idem, Ibidem, pp. 359-360). Também a nível urbano conseguiu D. Afonso alicerçar uma posição de domínio, isolando D. Pedro e mobilizando a população dos concelhos em torno da causa régia (Cf. doc. in A. F. Barata, "Vésperas de Alfarrobeira», Archivo Historico Portuguez, 1905, n. ${ }^{\circ} 5$ e 6, pp. 209-212 - carta de D. Afonso V à câmara de Evora, Abril de 1449; - Artur de Magalhães Basto, «O limiar da tragédia. Reflexos no Porto das vésperas de Alfarrobeira», Revista de História, n. ${ }^{\circ}$ XIII, Lisboa, 1924, esp. docs. n..$^{\circ} 17$ e 18, pp. 268-270 - cartas de $\mathrm{D}$. Afonso V à cidade do Porto, em 10 e 21 de Abril de 1449). Os resultados desta política são bem demonstrados pelos incidentes ocorridos, já em Maio, em Lisboa, onde «dous mancebos .... por aver nelles sospeita de trato por serem criados do Yfante, foram pubryca e inocentemente feytos em quartos, e postos pellos mais pubrycos lugares da cidade». (R. Pina, ob. cit., cap. CXVIII, p. 417).

(104) H. B. Moreno, ob. cit., p. 421, situa a saída de D. Pedro de Coimbra em 5 de Maio.

${ }^{(105)}$ Acerca do itinerário de D. Pedro entre Coimbra e Alfarrobeira e das peripécias entretanto ocorridas (incluindo a batalha), vide Idem, Ibidem, pp. 421-427.

$\left({ }^{108}\right)$ Sobre as sequelas, até $1451-52$, dos conflitos ocorridos neste periodo, pode ver-se Idem, Ibidem, esp. pp. 511-521 e 583-660. 
vante $\left({ }^{107}\right)$ ) tenhamos conhecimento de qualquer outro conflito político grave.

Isto não invalida contudo que, desde antes mesmo da morte de $\mathrm{D}$. Afonso $\mathrm{V}$, se não descortinassem já, no estilo de intervenção e nas intenções do jovem infante $\mathbf{D}$. João, os prenúncios de transformações deveras significativas. Exemplifi. cativo desta situação é, seguramente, o episódio ocorrido, em 1478, com Lopo Vaz de Castelo Branco, membro do conselho do rei, monteiro-mór e alcaide do castelo de Moura, que, por motivos ainda não totalmente explicitados, se revoltou subitamente nesta vila, tomando voz por Castela. Rapidamente abafado pelos seus próprios promotores, este levantamento terá sido perdoado pelo monarca, mas não por seu filho, o príncipe D. João, que disfrutava já de um vasto espaço de manobra na direcção política do Reino e a quem tais ousadias pareciam desagradar sobremaneira; daí que, na sequência de uma pequena conjura urdida por este e que envolvia alguns cavaleiros eborenses da sua casa, o alcaide de Moura tenha vindo a ser assassinado na sua própria vila, a qual, juntamente com o respectivo castelo, foi imediatamente ocupada por D. João e entregue à infanta D. Beatriz $\left({ }^{108}\right)$.

(107) o caso do incidente registado aquando do provimento de D. Alvaro Chaves no bispado da Guarda, alegadamente interceptado por $\mathrm{D}$. Afonso $\mathrm{V}$ por falta de consentimento régio (vide Fortunato de Almeida, História da Igreja em Portugal, I, Porto, 1967, p. 301) e também o dos atritos ocorridos entre o duque de Bragança e o Arcebispo de Braga, D. Fernando da Guerra, a propósito dos quais é solicitada pelo Papa a intervenção do rei (vide Visconde de Santarém, ob. cit., t. X, p. 67 - bula «Sublimium Magnificentia», de 1 de Janeiro de 1458, de Calisto III a D. Afonso V; José Marques, A Arquidiocese de Braga no século $X V$, Porto, 1981, II, esp. p. 911). Aliás, ainda durante a regência do infante $D$. Pedro, temos conhecimento de uma disputa havida com o Papa Eugénio IV, relacionada com a excomunhão (proferida nos concílios de Ferrara e Florença, em 1438 e 1439, respectivamente) do bispo de Viseu, D. Luís do Amaral, que, em 1437, no concílio de Basileia, tomara o partido do Papa Félix, contra Eugénio IV. Em substituição de D. Luís do Amaral, o papa proviu no bispado de Viseu a D. Luís Coutinho, no que se viu contrariado pelo infante D. Pedro. A questão ter-se-á arrastado até 1441 tendo, ao que parece, acabado por prevalecer a posição da Santa Sé (sobre esta matéria pode ver-se H. B. Moreno, ob. cit., t. II, p. 789).

${ }^{(109)}$ Temos notícia destes acontecimentos através das narrativas de R. Pina, ob. cit., cap. CCIV, pp. 586-587, Garcia de Resende, Chronica del Rey Dom Joam II, Coimbra, 1798, cap. XX, p. 24, e Damião de Góis, Crónica do Príncipe D. João, Lisboa, 1977 (ed. crítica de Graça A. Rodrigues), cap. XCVIII, pp. 202-203. Todos estes autores situam o incidente no ano de 1478 , sem indicação do mês ou dia, e acusam a presença de $D$. Afonso V no Reino, na mesma altura; os assassinos de Lopo Vaz são aqui identificados como sendo os irmãos 
Punição exemplar, se bem a entendemos, que terá dissipado as últimas dúvidas acerca da determinação do futuro monarca em consumar um processo de centralização do poder que outros, ingloriamente, haviam já ensaiado em ocasiões anteriores. Na realidade, logo após a morte de seu pai, em 1481, D. João II impõe, nas cortes reunidas na cidade de Évora, uma nova forma de menagem, claramente denunciadora da posição de subalternidade a que pretendia, a partir daí, ver confinada a alta nobreza, e a anulação de algumas medidas promulgadas por $\mathrm{D}$. Afonso $\mathrm{V}$ em favor de diversos nobres do Reino $\left({ }^{100}\right)$. A reaç̧ão não se fez esperar, dela resultando um curto mas violento confronto entre as principais figuras da nobreza de Portugal e o seu novo monarca.

0 primeiro momento deste confronto culmina na execução de D. Fernando, 3..$^{\circ}$ duque de Bragança e o mais poderoso fidalgo do Reino, consumada em Évora a 20 de Junho de $1483\left({ }^{110}\right)$. Principal opositor de D. João II nas cortes de 1481 e adversário feroz de algumas medidas tomadas por este

Palha (João, Mem, Pero e Brás) e dois dos seus primos, os irmãos Rui Gil e Diogo Gil, por alcunha os Magro.

Segundo uma das versôes da Crónica de Damião de Góis, este episódio surge na sequência de anteriores desavenças entre o alcaide e o infante D. João. Pela nossa parte, pensamos que o acontecimento só encontrará, de facto, explicação no mal-estar existente ao nível de importantes sectores da nobreza (habituados à generosidade e brandura da política de $\mathrm{D}$. Afonso $\mathrm{V}$ ), em virtude do comportamento disciplinador assumido pelo herdeiro da Coroa nos períodos em que, por motivo da ausência de seu pai, assumira a regência do Reino (1475 e 1476-77). Nestes momentos (num dos quais, no último trimestre de 1477, D. João chegou mesmo a ser aclamado como rei de Portugal, segundo indicação expressa de D. Afonso V, então em França e determinado em não regressar a Portugal) tornara-se muito evidente para os grupos dominantes na sociedade portuguesa a afinidade existente entre o projecto político de $\mathrm{D}$. João e aquele outro que, protagonizado pelo infante $D$. Pedro, havia saído derrotado em Alfarrobeira, poucas décadas atrás. Não será, portanto, por acaso que a revolta de Moura surge associada a um membro da família dos Castelo Branco, a quem D. Afonso V atribuíra - nomeadamente após 1449 diversas honras e mercês (vide H. B. Moreno, ob. cit., II, pp. 754-757; D. Góis, ob. cit., cap. CIII, p. 209).

${ }^{(100)}$ Acerca da nova forma de menagem, pode ver-se $R$. Pina, Chronica d'El Rey D. João II, Colecção de Inéditos, II, Lisboa, 1792, cap. V, pp. 19-20; Inácio de Vilhena Barbosa, «Forma das Menagens Ordenada por El-Rei D. João II», Panorama, vol. XIII, Lisboa, 1856, pp. 73-74. No que diz respeito às decisões das Cortes de Evora, veja-se R. Pina, ob. cit., esp. cap. V, p. 22; Joaquim Veríssimo Serrão, Evora, côrtes de 1481, in D.H.P., t. II, Porto, 1981, p. 498.

(10) Acerca dos antecedentes, desenvolvimento e desfecho do processo que levaria à execução do duque de Bragança deve ver-se 
monarca nos anos seguintes, consideradas como atentatórias dos direitos da nobreza (é, designadamente, o caso da permissão de entrada de corregedores régios nas suas propriedades), o duque de Bragança rapidamente se converte em cabecilha da resistência à política de D. João II. Credor, pelo menos desde 1481, da antipatia e desconfiança do monarca e protagonista de uma alegada aliança com os reis católicos castelhanos para derrubar o rei português, descoberta e denunciada a D. João II por alguns dos seus próprios servidores $\left({ }^{111}\right)$, o duque de Bragança vem a ser detido em Evora para, após julgamento ordenado pelo rei, ver todos os seus bens confiscados e acabar por ser degolado em praça pública, cerca de um mês depois $\left.{ }^{112}\right)$. Simultaneamente, eram alvo da justiça régia três dos irmãos do duque: $D$. João, Marquês de Montemor (também condenado à morte e a confisco dos bens, mas que conseguiu refugiar-se em Castela, onde viria a falecer), D. Alvaro (a quem D. João II concedeu a possibilidade do exílio) e D. Afonso, conde de Faro (que, considerando-se comprometido, se passou também para fora do Reino) ${ }^{(113}$ ), enquanto D. Diogo, duque de Viseu e irmão de D. Leonor, embora perdoado, era seriamente advertido pelo monarca.

Será, contudo, este mesmo D. Diogo quem conceberá, logo no ano de 1484, uma nova conspiração contra D. João II, contando para isso com a colaboração, entre outros, do bispo de Evora, D. Garcia de Meneses, e de seu irmão, D. Fernando

o coevo R. Pina, ob. cit., caps. V (pp. 20-22), VI (pp. 23-24), VIII (pp. 27-28), IX (pp. 31-32), X (pp. 33-36), XI (pp. 36-40), XIII (pp. 41-42) e XIV (pp. 42-52).

(111) Sobre a «matéria-crime» desta eventual aliança e sua denúncia, pode ver-se também L. Rebello da Silva, «D. João II e a nobreza», Annaes das Sciencias e Lettras, vol. I, 1857, pp. 412 e ss. (inclui o célebre «Tratado de Lopo de Figueiredo»).

(112) Acerca da forma de que se revestiu o julgamento do duque de Bragança e da! composição do respectivo juri, deve ver-se $H$. $B$. Moreno, $A$ conspiraşão contra D. João II - o julgamento do Duque de Bragança, Paris, 1970. O texto integral da sentença proferida contra D. Fernando encontra-se publicado por Anselmo Braancamp Freire, "As conspirações no reinado de D. João II», Archivo Historico Portuguez, vol. I, n..$^{\circ} 11$, Lisboa, 1903, doc. n. ${ }^{\circ}$ I, pp. 393-397. António Caetano de Sousa, ob. cit., esp. pp. 636 e ss., 775 e ss., e 791 e ss., apresenta diversos documentos relativos à posição de algumas individualidades que, posteriormente, se pronunciaram sobre a justiça e a validade (jurídica) da sentença.

(113) As sentenças proferidas em 17 de Setembro de 1483, contra o Marquês de Montemor, e em 1 de Junho de 1485, contra o conde de Faro, encontram-se publicadas por A. B. Freire, ob. cit., vol. I, n. ${ }^{\circ} 12,1903$, pp. $442-444$ e vol. II, n..$^{\circ}$, 1904, pp. 68-71, respectivamente. 
de Meneses, de Fernão da Silveira, filho do barão de Alvito, de D. Goterre Coutinho, comendador de Sesimbra, de D. Alvaro de Ataíde e seu filho, Pedro de Ataíde, e de Pero de Albuquerque e seu irmão Lopo de Albuquerque, conde de Penamacor $\left({ }^{114}\right)$. Intentavam os conspiradores assassinar o monar. ca e entronar, em sua substituição, o jovem infante $\mathbf{D}$. Afonso. Descoberto, porém, o plano, através da denúncia que Diogo Tinoco (irmão de uma manceba íntima do bispo de Evora) e D. Vasco Coutinho (irmão de D. Goterre) dele fizeram ao rei, o duque de Viseu é chamado a Setúbal, onde se encontrava D. João II, no dia 28 de Agosto de 1484. Nessa mesma noite, e perante alguns fidalgos da sua casa, o próprio monarca apunhala mortalmente o cunhado, pondo assim termo à conjura. Seguiu-se-lhe, de imediato, a realização de um inquérito comprovativo da culpabilidade de $\mathrm{D}$. Diogo e a perseguição e castigo dos restantes conspiradores $\left({ }^{115}\right)$.

Eliminados os paladinos das grandes casas nobiliárquicas de Bragança e de Viseu, em torno de quem se havia polarizado a oposição à política joanina, a realeza via abrir-se-lhe pela frente o caminho da centralização do poder. Era como se se

(114) Sobre as peripécias que rodearam a conspiração do duque de Viseu contra D. João II, veja-se R. Pina, ob. cit., caps. XVII (pp. 55-57) e XVIII (pp. 57-59).

(115) $O$ auto de inquirição das testemunhas, a que se procedeu por ocasião da morte do duque de Viseu, encontra-se trasladado nas Chronicas dos Senhores Reis de Portugal, de Cristóvão R. Acenheiro, Coleç̧ão de Inéditos, V, pp. 308-314. Entretanto, A. B. Freire, ob. cit., vol. I, n. ${ }^{\circ} 11,1903$, p. 391, manifestou a intenção de o republicar, com base em «copias mais correctas existentes na Torre do Tombo e na Biblioteca de Evoras, sem que tenhamos, contudo, conhecimento de o ter levado a efeito.

No que diz respeito ao futuro dos cúmplices de D. Diogo, objecto da intransigência do monarca, veja-se R. Pina, ob. cit., esp. cap. XVIII, pp. 60-63, e A. B. Freire, ob. cit., vol. I, n. ${ }^{\circ} 12,1903$ e vol. II, n. ${ }^{\circ}$ a 9, 1904 (texto integral das sentenças proferidas contra vários dos conspiradores). Adiante-se, entretanto, que os respectivos processos se encontravam concluídos cerca de um ano depois, poucos sendo os que escaparam à alçada da justiça régia (refira-se, a este propósito, que Ricardina Vélhinho Condeça, Resenha dos manuscritos referentes ao reinado de D. João II, existentes na Biblioteca Geral da Universidade de Coimbra, Coimbra, 1966 (tese de licenc., dactil.), pp. 338-345, transcreve uma curiosa carta, inédita, sem data e dirigida a D. João II, da autoria de Fernão da Silveira - um dos conspiradores que conseguiu furtar-se, fugindo de Portugal, à repressão que se seguiu à descoberta da conjura -, na qual aquele nobre exprime ao monarca português, de uma forma desabrida e acusatória, as suas críticas em relação à forma como $D$. João II conduzia a política do Reino e, em particular, à maneira como se comportava para com a nobreza). 
encerrasse um primeiro ciclo (o medieval) da história política portuguesa; ao mandar retirar do Escudo Real a Cruz Verde da Ordem de Avis ( $\left.{ }^{116}\right)$, portentado senhorial que dera corpo ao ordenamento socio-político da segunda dinastia do Reino, D. João II inaugurava, simbolicamente, um novo rumo para Portugal.

(116) Vide R. Pina, ob. cit., cap. XIX, pp. 64-65. 